\title{
Encapsulation of phosphorescent $\mathrm{Pt}$ (II) complexes in Zn-based metal-organic frameworks towards oxygen-sensing porous materials
}

Tim-Oliver Knede $\ddagger^{\ddagger},{ }^{[a]}$ Stefan Buss $\left.{ }^{\ddagger},[b, c]\right]$ Iván Maisuls, ${ }^{[b, c]}$ Constantin G. Daniliuc, ${ }^{[d]}$. Carsten Schlüsener, [a] Philipp Brandt, [a] Oliver Weingart, [e] Annette Vollrath,,[a] Christoph Janiak*[a], Cristian A. Strassert ${ }^{*[b, c]}$

[a] Institut für Anorganische Chemie und Strukturchemie, Heinrich-Heine-Universität Düsseldorf Universitätsstraße 1, 40225 Düsseldorf, Germany

[b] CiMIC, SoN, Institut für Anorganische und Analytische Chemie, Westfälische Wilhelms-Universität Münster - Corrensstraße 28/30, 48149 Münster, Germany

[c] CeNTech, Westfälische Wilhelms-Universität Münster - Heisenbergstraße 11, 48149 Münster, Germany

[d] Organisch-Chemisches Institut, Westfälische Wilhelms-Universität Münster - Corrensstraße 40, 48149 Münster, Germany

[e] Institut für Theoretische Chemie und Computerchemie, Heinrich-Heine-Universität Düsseldorf Universitätsstraße 1, 40225 Düsseldorf, Germany

期ese authors contributed equally to this work.

E-Mail: ca.s@wwu.de,janiak@uni-duesseldorf.de

Section S1: Materials and methods

Section S2: Synthesis and characterization of $[\mathrm{PtCl}(\mathrm{L})]$ and $[\mathrm{PtCN}(\mathrm{L})]$

Section S3: NMR spectra of 1, 2a, 2b, $\mathrm{LH},[\mathrm{PtCl}(\mathrm{L})]$ and $[\mathrm{PtCN}(\mathrm{L})]$

Section S4: IR spectra of $[\mathrm{PtCl}(\mathrm{L})]$ and $[\mathrm{PtCN}(\mathrm{L})]$

Section S5: Single crystal X-ray diffraction analysis of $1,2 b,[\mathrm{PtCl}(\mathrm{L})]$ and [PtCN(L)]

Section S6: Photophysical characterization of $[\mathrm{PtCl}(\mathrm{L})]$ and $[\mathrm{PtCN}(\mathrm{L})]$

Section S7: Synthesis and characterization of $[\mathrm{PtCl}(\mathrm{L})] @ M O F$ and $[\mathrm{PtCN}(\mathrm{L})] @ \mathrm{MOF}$

Section S8: Atomic absorption spectroscopy of [PtCN(L)@MOF and $[\mathrm{PtCl}(\mathrm{L})] @ \mathrm{MOF}$

Section S9: Confocal laser scanning microscopy of [PtCN(L)]@MOF-5, [PtCl(L)]@MOF-5 and MOF-5 (single crystals)

Section S10: Photophysical characterization of $[\mathrm{PtCl}(\mathrm{L})] @ M O F$ and [PtCN(L)]@MOF 


\section{Section S1: Materials and methods}

Commercially available reagents were used without further purification. Silica gel 60 $(0.063-0.200 \mathrm{~mm})$ for column chromatography was purchased from Merck (mentioned as silica) and aluminium oxide 90 standardized for column chromatography adsorption analysis acc. to Brockmann from Merck (mentioned as alumina) were used for column chromatography, if not otherwise stated.

NMR spectra were obtained at the Organisch-Chemisches Institut Münster (WWU), using an Agilent DD2 500 / Agilent DD2 600 or a Bruker Avance II 400. All measurements were performed at room temperature unless mentioned otherwise. The ${ }^{1} \mathrm{H}-\mathrm{NMR}$ and ${ }^{13} \mathrm{C}$-NMR chemical shifts $(\delta)$ of the signals are given in parts per million and are referenced to the residual proton signal in the deuterated solvent methylene chloride- $d_{2}\left({ }^{1} \mathrm{H}: 5.32 \mathrm{ppm} /{ }^{13} \mathrm{C}: 54.0 \mathrm{ppm}\right)$ or dimethylformamide- $d_{7}\left({ }^{1} \mathrm{H}: 8.03 \mathrm{ppm}\right.$, $2.92 \mathrm{ppm}, 2.75 \mathrm{ppm} /{ }^{13} \mathrm{C}$ : $\left.163.2 \mathrm{ppm}, 34.9 \mathrm{ppm}, 29.8 \mathrm{ppm}\right)$. The signal multiplicities are abbreviated as follows: $s$, singlet; $d$, doublet; $t$, triplet; q, quartet; $m$, multiplet.

Exact mass (EM) determination by mass spectrometry (MS) was carried out at the Organisch-Chemisches Institut in Münster (WWU) using a LTQ Orbitap LTQ XL (Thermo-Fisher Scientific, Bremen) with electron spray injection (ESI).

IR spectra were obtained on a Bruker Tensor 37 FT-IR spectrometer equipped with a A225 Platinum ATR diamond unit, measured from $4000-550 \mathrm{~cm}^{-1}$.

Atomic absorption spectroscopy (AAS) was carried out on a PinAAcle 900T spectrometer from Perkin Elmer equipped with an AS900 autosampler and a single element platinum hollow cathode lamp. Measurements were performed in a stabilized temperature platform furnace (STPF) with Zeeman correction. For all samples, approx. 0.5 to $1.5 \mathrm{mg}$ of the sample was dissolved in $1,2,8,16$ or $32 \mathrm{~mL}$, of $5 \% \mathrm{HCl}$ in DMSO, depending on the amount of platinum in the sample. MOF- 5 samples were previously dried at $80^{\circ} \mathrm{C}$ in vacuum for $1 \mathrm{~h}$. Zinc concentrations were determined with a $10 \mathrm{~cm}$ acetylene-air burner and a multielement $\mathrm{Al}, \mathrm{Cu}, \mathrm{Fe}, \mathrm{Cr}, \mathrm{Zn}$ hollow cathode lamp. From the samples prepared for Pt-analysis, $0.1 \mu \mathrm{L}$ was taken and diluted to $50 \mathrm{~mL}$.

Powder X-ray diffraction (PXRD) was measured on a Bruker D2 phaser (300 W, 30kV, $10 \mathrm{~mA})$ using Cu-Ka radiation $(\lambda=1.54 \AA)$ at ambient temperature with a scanning rate of $0.0125 \%$ s. A flat, low background sample holder was used, on which the beam spot is strongly broadened at low angle so that only a fraction of the reflected radiation reaches the detector, resulting in low intensities for reflections $2 \Theta<7^{\circ}$.

Scanning electron microscopy (SEM) images were obtained on a Jeol JSM 6510 electron microscope at 5-20 keV with a $\mathrm{LaB}_{6}$-cathode.

$\mathrm{N}_{2}$-sorption isotherms were measured on a Quantachrome Autosorb-6 at $77 \mathrm{~K}$ and Ar-sorptions on a Quantachrome Autosorb IQ MP at $87 \mathrm{~K}$. Samples were placed in pre-weighted glass tubes capped with a septum. The sample was degassed on a Quantachrome degasser ( $\mathrm{N}_{2}$-sorptions) or on the Quantachrome Autosorb IQ MP (Ar-sorptions) in a dynamic vacuum of $10^{-2} \mathrm{mbar}$ for $3 \mathrm{~h}$ at $120^{\circ} \mathrm{C}$ (MOF-5) or $130^{\circ} \mathrm{C}$ (ZIF-8), weighted again and transferred to the measurements port. 
Density functional theory (DFT) calculations for the pore size distribution were done with the 'ASWin 2.03' software for $\mathrm{N}_{2}$-sorptions using the ' $\mathrm{N}_{2}$ at $77 \mathrm{~K}$ on carbon, slit pore, NLDFT equilibrium model' and for Ar-sorptions with the 'ASiQwin' software using the 'Ar at $87 \mathrm{~K}$ zeolites/silica, spherical/cylindrical pores, NLDFT ads. Model'.

Confocal fluorescence microscopy images were collected on an Olympus Fluoview 1000 inverse confocal microscope system with an internal $405 \mathrm{~nm}$ laser and a 6channel single photon detector.

DFT calculations were performed for MOF-5 and [PtCN(L)] alone as well as MOF-5 with one adsorbed [PtCN(L)] per unit cell using the Quantum-Espresso software. ${ }^{1}$ The crystal structure of MOF-5 (CCDC 256965) served as starting geometry. Structure and cell parameters were optimized using the Broyden-Fletcher-Goldfarb-Shanno (BFGS) scheme, ultrasoft Rappe Rabe Kaxiras Joannopoulos (rrkjus) pseudoptentials for C, $\mathrm{N}, \mathrm{O}$ and $\mathrm{H}$ atoms, ultrasoft Vanderbilt-type pseudopotentials for $\mathrm{Zn}, \mathrm{S}$ and $\mathrm{Pt}$ and the generalized gradient approximation (GGA) with Perdew-Burke-Enzerhof (PBE) exchange correlation. The semi-empirical Grimme D2-correction scheme was applied to account for dispersion effects. ${ }^{2}$ Calculations were restricted to the $\Gamma$-point with an energy cut-off of 65 Rydberg and a charge cut-off of 650 Rydberg. After geometry optimization of the MOF-5 structure, a $[\operatorname{PtCN}(\mathrm{L})]$ molecule was manually placed at the center of the unit cell and both, geometry and cell were allowed to fully relax. To compute the binding energy of [PtCN(L)], we optimized a single [PtCN(L)] molecule in an empty cell of the same size as the MOF-5 structure and under the same conditions stated before. The binding energy was then obtained as the difference between the sum of energies of MOF-5 and [PtCN(L)] and the energy of MOF-5 including the adsorbed [PtCN(L)] molecule. 


\section{Section S2: Synthesis and characterization of $[\mathrm{PtCN}(\mathrm{L})]$ and $[\mathrm{PtCl}(\mathrm{L})]$}

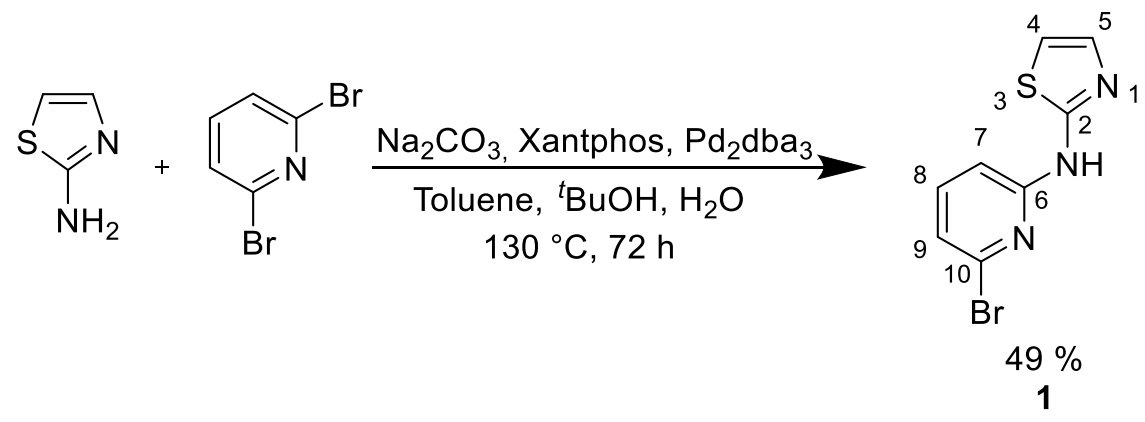

$\mathrm{N}$-(6-bromopyridin-2-yl)-thiazol-2-amine (1). 2-Aminothiazole $(400 \mathrm{mg}, 4.0 \mathrm{mmol}$, 1.0 eq), 2,6-dibromopyridine (2.83 g, $12.0 \mathrm{mmol}, 3.0$ eq.), $\mathrm{Na}_{2} \mathrm{CO}_{3}(1.43 \mathrm{~g}, 12.0 \mathrm{mmol}$, 3.0 eq.) and Xantphos (100 mg, $0.32 \mathrm{mmol}, 0.08$ eq.) were dissolved in toluene $(40 \mathrm{~mL}),{ }^{\mathrm{B}} \mathrm{BuOH}(5 \mathrm{~mL})$ and $\mathrm{H}_{2} \mathrm{O}(0.1 \mathrm{~mL})$. The mixture was degassed for $5 \mathrm{~min}$. Afterwards, $\mathrm{Pd}_{2}(\mathrm{dba})_{3}(120.9 \mathrm{mg}, 0.132 \mathrm{mmol}, 0.033$ eq.) was added and the mixture was again degassed for $5 \mathrm{~min}$ and heated to reflux for $72 \mathrm{~h}$. After reaching room temperature, the mixture was filtered, and the residue was washed with $\mathrm{DCM}(100 \mathrm{~mL})$. The combined solutions were washed with des. $\mathrm{H}_{2} \mathrm{O}(100 \mathrm{~mL})$ and brine $(100 \mathrm{~mL})$. The solvent was removed under reduced pressure and after purification via column chromatography over silica eluting with a mixture of EtOAc/cyclohexane $(\mathrm{V}: \mathrm{V}=3: 7)$, the product (1) was obtained as a white solid. Yield: $505 \mathrm{mg}, 1.96 \mathrm{mmol}, 49 \%$. Colorless crystals of $\mathbf{1}$ were obtained as needles from slow evaporation of a EtOAc/cyclohexane-mixture (60/40).

${ }^{1} \mathrm{H}-\mathrm{NMR}\left(400 \mathrm{MHz}, \mathrm{CD}_{2} \mathrm{Cl}_{2}\right), \delta(\mathrm{ppm})=7.56-7.46\left(\mathrm{~m}, 2 \mathrm{H}, \mathrm{H}_{5+8}\right), 7.08$ (dd, $\left.{ }^{3} \mathrm{~J}_{\mathrm{HH}}=7.6 \mathrm{~Hz},{ }^{4} \mathrm{JHH}_{\mathrm{HH}}=0.6 \mathrm{~Hz}, 1 \mathrm{H}, \mathrm{H}_{7 / 9}\right), 6.95\left(\mathrm{~d},{ }^{3} \mathrm{~J}_{\mathrm{HH}}=3.6 \mathrm{~Hz}, 1 \mathrm{H}, \mathrm{H}_{4}\right), 6.91(\mathrm{dd}$, $\left.{ }^{3} J_{\mathrm{HH}}=8.1 \mathrm{~Hz},{ }^{4} J_{\mathrm{HH}}=0.7 \mathrm{~Hz}, 1 \mathrm{H}, \mathrm{H}_{7 / 9}\right)$.

${ }^{13} \mathbf{C}-\{1 \mathrm{H}\}-N M R\left(101 \mathrm{MHz}, \mathrm{CD}_{2} \mathrm{Cl}_{2}\right), \delta(\mathrm{ppm})=161.7\left(\mathrm{C}_{2}\right), 152.1\left(\mathrm{C}_{6 / 10}\right), 140.4\left(\mathrm{C}_{8}\right)$, $139.3\left(\mathrm{C}_{6 / 10}\right), 137.0\left(\mathrm{C}_{5}\right), 120.1\left(\mathrm{C}_{7 / 9}\right), 112.3\left(\mathrm{C}_{4}\right), 109.5\left(\mathrm{C}_{7 / 9}\right)$.

EM-MS-ESI $\left(\mathrm{MeOH} / \mathrm{CHCl}_{3}, \mathrm{C}_{8} \mathrm{H}_{6} \mathrm{~N}_{3} \mathrm{SBr}\right.$ ), $\mathrm{m} / z=279.93350$ (found for $[\mathrm{M}+\mathrm{Na}]^{+}$), 279.93369 (calcd. for $[\mathrm{M}+\mathrm{Na}]^{+}$); 534.88024 (found for [2M+Na] ${ }^{+}$), 534.88031 (calcd. for $\left.[2 \mathrm{M}+\mathrm{Na}]^{+}\right)$.

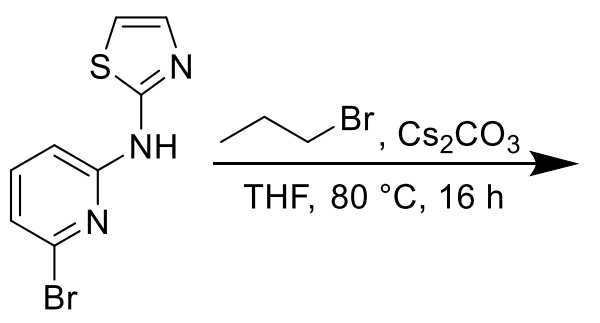

1

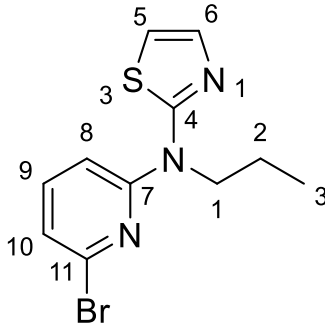

$40 \%$

$2 a$

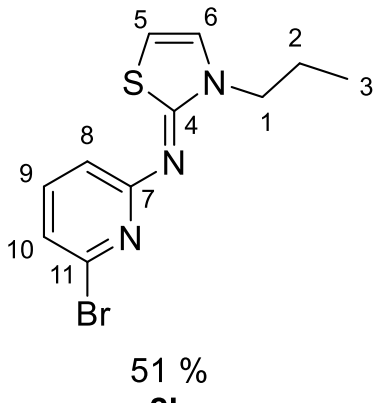

2b

$\mathbf{N}$-(6-bromopyridin-2-yl)-N-propyl-thiazol-2-amine (2a). 1 (1.0 g, $3.90 \mathrm{mmol}, 1.0 \mathrm{eq}$ ) and $\mathrm{Cs}_{2} \mathrm{CO}_{3}(2.5 \mathrm{~g}, 11.70 \mathrm{mmol}, 3.0 \mathrm{eq})$ were suspended in THF $(25 \mathrm{~mL})$. After addition of 1-bromopropane $(1.0 \mathrm{~mL}, 7.80 \mathrm{mmol}$. $2.0 \mathrm{eq})$, the mixture was heated $16 \mathrm{~h}$ to reflux. The reaction mixture was poured on dest. $\mathrm{H}_{2} \mathrm{O}(50 \mathrm{~mL})$ and the aqueous 
phase was extracted with EtOAc $(3 \times 30 \mathrm{~mL})$. The collected organic phases were washed with brine $(50 \mathrm{~mL})$, dried over $\mathrm{Na}_{2} \mathrm{SO}_{4}$ and the solvent was removed under reduced pressure. After purification via column chromatography over silica eluting with a mixture of THF/cyclohexane $(\mathrm{V}: \mathrm{V}=1: 19)$, the desired product $(\mathbf{2 a})$ was obtained as a colorless oil (466 mg, $1.56 \mathrm{mmol}, 40 \%$ ), whereas the undesired product (2b) eluted second also as a white (low melting) solid/colorless oil (596 mg, $2.00 \mathrm{mmol}, 51 \%$ ). For crystallization, $\mathbf{2 b}$ was dissolved in hot cyclohexane and allowed to cool to $4{ }^{\circ} \mathrm{C}$ overnight to get colorless prism-like crystals.

\section{Analysis 2a:}

${ }^{1} \mathrm{H}-\mathrm{NMR}\left(400 \mathrm{MHz}, \mathrm{CD}_{2} \mathrm{Cl}_{2}\right), \delta(\mathrm{ppm})=7.52\left(\mathrm{dd},{ }^{3} \mathrm{JHH}_{\mathrm{HH}}=8.4 \mathrm{~Hz},{ }^{3} \mathrm{JHH}_{\mathrm{HH}}=7.5 \mathrm{~Hz}, 1 \mathrm{H}, \mathrm{H}_{9}\right)$, $7.46\left(\mathrm{~d},{ }^{3} \mathrm{JHH}_{\mathrm{HH}}=3.7 \mathrm{~Hz}, 1 \mathrm{H}, \mathrm{H}_{6}\right), 7.06\left(\mathrm{dd},{ }^{3}{ }_{\mathrm{HH}}=7.6 \mathrm{~Hz},{ }^{4}{ }_{\mathrm{HH}}=0.5 \mathrm{~Hz}, 1 \mathrm{H}, \mathrm{H}_{8}\right), 6.97$ $\left(\mathrm{dd},{ }^{3} \mathrm{~J}_{\mathrm{HH}}=8.4 \mathrm{~Hz},{ }^{4} \mathrm{JHH}_{\mathrm{HH}}=0.5 \mathrm{~Hz}, 1 \mathrm{H}, \mathrm{H}_{10}\right), 6.92\left(\mathrm{~d},{ }^{3} \mathrm{~J}_{\mathrm{HH}}=3.7 \mathrm{~Hz}, 1 \mathrm{H}, \mathrm{H}_{5}\right), 4.31-4.25$ $\left(\mathrm{m}, 2 \mathrm{H}, \mathrm{H}_{1}\right), 1.89-1.72\left(\mathrm{~m}, 2 \mathrm{H}, \mathrm{H}_{2}\right), 1.01\left(\mathrm{t},{ }^{3} \mathrm{HH}=7.5 \mathrm{~Hz}, 3 \mathrm{H}, \mathrm{H}_{3}\right)$.

${ }^{13} \mathrm{C}-\left\{{ }^{1} \mathrm{H}\right\}$-NMR $\left(101 \mathrm{MHz}, \mathrm{CD}_{2} \mathrm{Cl}_{2}\right), \delta(\mathrm{ppm})=161.5\left(\mathrm{C}_{4}\right), 152.9\left(\mathrm{C}_{7}\right), 140.5\left(\mathrm{C}_{9}\right), 138.3$ $\left(\mathrm{C}_{11}\right), 137.5\left(\mathrm{C}_{6}\right), 119.8\left(\mathrm{C}_{8}\right), 113.6\left(\mathrm{C}_{5}\right), 108.0\left(\mathrm{C}_{10}\right), 50.1\left(\mathrm{C}_{1}\right), 20.5\left(\mathrm{C}_{2}\right), 11.5\left(\mathrm{C}_{3}\right)$.

EM-MS-ESI $\left(\mathrm{MeOH} / \mathrm{CHCl}_{3}, \mathrm{C}_{11} \mathrm{H}_{12} \mathrm{~N}_{3} \mathrm{SBr}\right), \mathrm{m} / \mathrm{z}=299.99859$ (found for $\left.[\mathrm{M}+\mathrm{H}]^{+}\right)$, 299.99873 (calcd. for $[\mathrm{M}+\mathrm{H}]^{+}$); 321.98055 (found for $[\mathrm{M}+\mathrm{Na}]^{+}$), 321.98067 (calcd. for $\left.[\mathrm{M}+\mathrm{Na}]^{+}\right) ; 618.97478$ (found for $\left.[2 \mathrm{M}+\mathrm{Na}]^{+}\right), 618.97427$ (calcd. for $[2 \mathrm{M}+\mathrm{Na}]^{+}$).

\section{Analysis 2b:}

${ }^{1} \mathrm{H}-\mathrm{NMR}\left(400 \mathrm{MHz}, \mathrm{CD}_{2} \mathrm{Cl}_{2}\right), \delta(\mathrm{ppm})=7.41\left(\mathrm{dd},{ }^{3} \mathrm{JHH}_{\mathrm{HH}}=8.0 \mathrm{~Hz},{ }^{3} \mathrm{~J}_{\mathrm{HH}}=7.5 \mathrm{~Hz}, 1 \mathrm{H}, \mathrm{H}_{9}\right)$, $6.96\left(\mathrm{dd},{ }^{3} \mathrm{~J}_{\mathrm{HH}}=8.0 \mathrm{~Hz},{ }^{4} \mathrm{~J}_{\mathrm{HH}}=0.8 \mathrm{~Hz}, 1 \mathrm{H}, \mathrm{H}_{8 / 10}\right), 6.94 \quad\left(\mathrm{dd},{ }^{3} \mathrm{~J}_{\mathrm{HH}}=7.5 \mathrm{~Hz}\right.$, $\left.{ }^{4} \mathrm{JHH}_{\mathrm{HH}}=0.8 \mathrm{~Hz}, 1 \mathrm{H}, \mathrm{H}_{8 / 10}\right), 6.88\left(\mathrm{~d},{ }^{3} \mathrm{~J}_{\mathrm{HH}}=4.8 \mathrm{~Hz}, 1 \mathrm{H}\right), 6.41\left(\mathrm{~d},{ }^{3} \mathrm{~J}_{\mathrm{HH}}=4.8 \mathrm{~Hz}, 1 \mathrm{H}\right), 4.10$ - $4.02\left(\mathrm{~m}, 2 \mathrm{H}, \mathrm{H}_{1}\right), 1.87-1.75\left(\mathrm{~m}, 2 \mathrm{H}, \mathrm{H}_{2}\right), 0.96\left(\mathrm{t},{ }^{3} \mathrm{JHH}_{\mathrm{HH}}=7.4 \mathrm{~Hz}, 3 \mathrm{H}, \mathrm{H}_{3}\right)$.

${ }^{13} \mathrm{C}-\left\{{ }^{1} \mathrm{H}\right\}$-NMR $\left(101 \mathrm{MHz}, \mathrm{CD}_{2} \mathrm{Cl}_{2}\right), \delta(\mathrm{ppm})=160.5\left(\mathrm{C}_{4}\right), 159.4\left(\mathrm{C}_{7}\right), 139.5\left(\mathrm{C}_{9}\right), 138.2$ ( $\left.\mathrm{C}_{11}\right), 126.6\left(\mathrm{C}_{6}\right), 118.9\left(\mathrm{C}_{8 / 10}\right), 117.9\left(\mathrm{C}_{8 / 10}\right), 105.4\left(\mathrm{C}_{5}\right), 49.9\left(\mathrm{C}_{3}\right), 22.7\left(\mathrm{C}_{2}\right), 11.5\left(\mathrm{C}_{1}\right)$.

EM-MS-ESI $\left(\mathrm{MeOH} / \mathrm{CHCl}_{3}, \mathrm{C}_{11} \mathrm{H}_{12} \mathrm{~N}_{3} \mathrm{SBr}\right), \mathrm{m} / \mathrm{z}=299.99804$ (found for $\left.[\mathrm{M}+\mathrm{H}]^{+}\right)$, 299.99873 (calcd. for $[\mathrm{M}+\mathrm{H}]^{+}$); 321.98007 (found for $[\mathrm{M}+\mathrm{Na}]^{+}$), 321.98067 (calcd. for $\left.[\mathrm{M}+\mathrm{Na}]^{+}\right) ; 618.97356$ (found for $\left.[2 \mathrm{M}+\mathrm{Na}]^{+}\right), 618.97427$ (calcd. for $[2 \mathrm{M}+\mathrm{Na}]^{+}$).

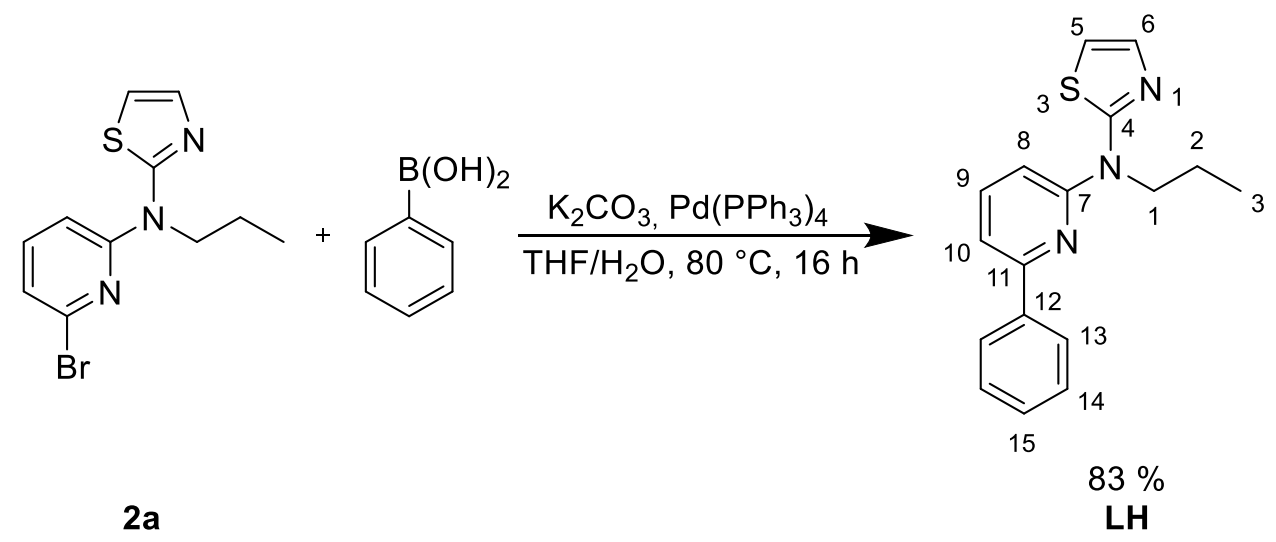

$\mathrm{N}$-(6-phenylpyridin-2-yl)-N-propyl-thiazol-2-amine (LH). 2a (157 mg; $0.52 \mathrm{mmol}$; $1.0 \mathrm{eq}$ ), phenylboronic-acid (96.0 mg; $0.79 \mathrm{mmol} ; 1.5 \mathrm{eq}), \quad \mathrm{Pd}\left(\mathrm{PPh}_{3}\right)_{4} \quad(57.8 \mathrm{mg}$; $0.052 \mathrm{mmol}$; $0.1 \mathrm{eq})$ were dissolved in THF $(15 \mathrm{~mL})$ and degassed for $5 \mathrm{~min}$. A $2 \mathrm{M}$ 
solution of aqueous $\mathrm{K}_{2} \mathrm{CO}_{3}(2 \mathrm{~mL} ; 4 \mathrm{mmol})$ was added and the mixture was again degassed for $5 \mathrm{~min}$. The reaction mixture was heated to reflux for $16 \mathrm{~h}$ and after reaching room temperature, water was added $(25 \mathrm{~mL})$ and the mixture was extracted with EtOAc $(3 \times 30 \mathrm{~mL})$. The collected organic phases were dried over $\mathrm{Na}_{2} \mathrm{SO}_{4}$ and the solvent was removed under reduced pressure. After purification via column chromatography over silica, with an eluent of EtOAc/cyclohexane $(\mathrm{V}: \mathrm{V}=1: 19)$, the product was obtained as a white (low melting) solid/colourless oil (127 mg, $0.43 \mathrm{mmol}, 83 \%)$.

${ }^{1} \mathrm{H}-\mathrm{NMR}\left(500 \mathrm{MHz}, \mathrm{CD}_{2} \mathrm{Cl}_{2}\right), \delta(\mathrm{ppm})=8.21-8.11\left(\mathrm{~m}, 2 \mathrm{H}, \mathrm{H}_{13}\right), 7.77$ (dd, $\left.{ }^{3} \mathrm{JHH}_{\mathrm{HH}}=8.5 \mathrm{~Hz},{ }^{3} \mathrm{H}_{\mathrm{HH}}=7.5 \mathrm{~Hz}, 1 \mathrm{H}, \mathrm{H}_{9}\right), 7.53$ (ddd, ${ }^{3} \mathrm{JHH}_{\mathrm{HH}}=7.6 \mathrm{~Hz},{ }^{3} \mathrm{~J}_{\mathrm{HH}}=6.9 \mathrm{~Hz}$, $\left.{ }^{4} \mathrm{JHH}_{\mathrm{HH}}=1.2 \mathrm{~Hz}, 2 \mathrm{H}, \mathrm{H}_{14}\right), 7.49-7.43\left(\mathrm{~m}, 2 \mathrm{H}, \mathrm{H}_{6+15}\right), 7.37$ (dd, ${ }^{3} \mathrm{~J}_{\mathrm{HH}}=7.5 \mathrm{~Hz}$, $\left.{ }^{4} J_{\mathrm{HH}}=0.6 \mathrm{~Hz}, 1 \mathrm{H}, \mathrm{H}_{10}\right), 7.04\left(\mathrm{dd},{ }^{3} \mathrm{~J}_{\mathrm{HH}}=8.5 \mathrm{~Hz},{ }^{4} J_{\mathrm{HH}}=0.6 \mathrm{~Hz}, 1 \mathrm{H}, \mathrm{H}_{8}\right), 6.87(\mathrm{~d}$, $\left.{ }^{3} \mathrm{JHH}_{\mathrm{H}}=3.7 \mathrm{~Hz}, 1 \mathrm{H}, \mathrm{H}_{5}\right), 4.44-4.32\left(\mathrm{~m}, 2 \mathrm{H}, \mathrm{H}_{1}\right), 2.09-1.77\left(\mathrm{~m}, 2 \mathrm{H}, \mathrm{H}_{2}\right), 1.07(\mathrm{t}$, $\left.{ }^{3} \mathrm{HHH}=7.5 \mathrm{~Hz}, 3 \mathrm{H}, \mathrm{H}_{3}\right)$.

${ }^{13} \mathrm{C}-\left\{{ }^{1} \mathrm{H}\right\}-N M R\left(126 \mathrm{MHz}, \mathrm{CD}_{2} \mathrm{Cl}_{2}\right), \delta(\mathrm{ppm})=162.0\left(\mathrm{C}_{4}\right), 156.3\left(\mathrm{C}_{11}\right), 153.4\left(\mathrm{C}_{7}\right), 139.7$ $\left(\mathrm{C}_{12}\right), 139.2\left(\mathrm{C}_{9}\right), 137.5\left(\mathrm{C}_{6}\right), 129.5\left(\mathrm{C}_{15}\right), 129.2\left(\mathrm{C}_{14}\right), 128.2\left(\mathrm{C}_{13}\right), 113.8\left(\mathrm{C}_{10}\right), 112.6$ ( $\left.\mathrm{C}_{5}\right), 108.5\left(\mathrm{C}_{8}\right), 50.5\left(\mathrm{C}_{1}\right), 20.7\left(\mathrm{C}_{2}\right), 11.6\left(\mathrm{C}_{3}\right)$.

EM-MS-ESI $\left(\mathrm{MeOH} / \mathrm{CHCl}_{3}, \mathrm{C}_{17} \mathrm{H}_{17} \mathrm{~N}_{3} \mathrm{~S}\right), \mathrm{m} / \mathrm{z}=296.12193$ (found for $[\mathrm{M}+\mathrm{H}]^{+}$), 296.12159 (calcd. for $[\mathrm{M}+\mathrm{H}]^{+}$); found. 319.10723 (found for $[\mathrm{M}+\mathrm{Na}]^{+}$), calcd. 319.10643 (calcd. for $[\mathrm{M}+\mathrm{Na}]^{+}$); found. 334.07791 (found for $[\mathrm{M}+\mathrm{K}]^{+}$), calcd. 334.07748 (calcd. for $\left.[\mathrm{M}+\mathrm{K}]^{+}\right)$; found. 613.21877 (found for $[2 \mathrm{M}+\mathrm{Na}]^{+}$), calcd. 613.21786 (calcd. for $\left.[2 \mathrm{M}+\mathrm{Na}]^{+}\right)$.<smiles>CCCN(c1cccc(-c2ccccc2)n1)c1nccs1</smiles>

$\mathrm{LH}$

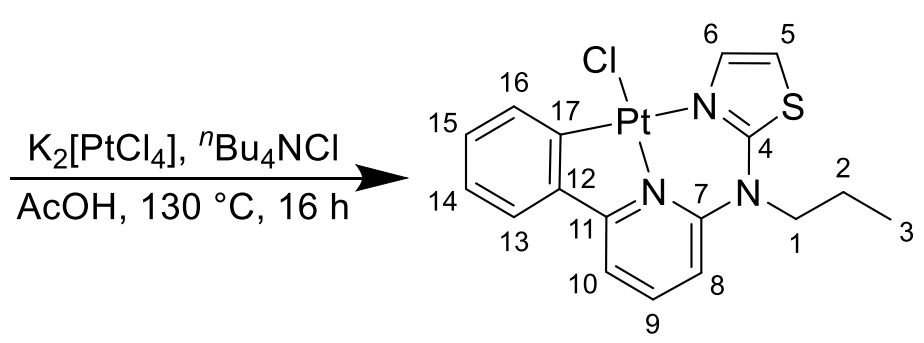

$65 \%$

[LPtCl]

\section{Chlorido-( $\mathrm{K}^{3} \mathrm{cNN}-\mathrm{N}-(6-$-phenylpyridin-2-yl)-N-propyl-thiazol-2-amino)-platinum(II)}

[PtCl(L)]. LH (1.00 eq, $0.54 \mathrm{mmol}, 160.0 \mathrm{mg}), \quad \mathrm{K}_{2}\left[\mathrm{PtCl}_{4}\right] \quad(1.00 \mathrm{eq}, 0.54 \mathrm{mmol}$, $176.8 \mathrm{mg}$ ) and ${ }^{\mathrm{n}} \mathrm{Bu} 4 \mathrm{NCl}$ (catalytic amount) were added to glacial acetic acid (15 mL) and the mixture was heated to reflux for $16 \mathrm{~h}$. The solvent was then removed under reduced pressure. The residue was purified via filtration over silica with DCM. The yellow spot was collected, and the solvent was removed under reduced pressure. The product was obtained as a yellow-greenish solid (182 mg, $0.35 \mathrm{mmol}, 65 \%)$. Yellow plate-like crystals were obtained from slow evaporation of a DCM solution.

${ }^{1} \mathrm{H}-\mathrm{NMR}\left(500 \mathrm{MHz}, \mathrm{DMF}-\mathrm{d}_{7}\right), \delta(\mathrm{ppm})=8.55\left(\mathrm{~d},{ }^{3} \mathrm{JHH}_{\mathrm{HH}}=4.1 \mathrm{~Hz}, 1 \mathrm{H}, \mathrm{H}_{6}\right), 8.30(\mathrm{dd}$, $\left.{ }^{3} \mathrm{HHH}_{\mathrm{HH}}=8.6 \mathrm{~Hz},{ }^{3} \mathrm{JHH}_{\mathrm{HH}}=7.8 \mathrm{~Hz}, 1 \mathrm{H}, \mathrm{H}_{9}\right), 8.09$ (ddd, ${ }^{3} \mathrm{~J}_{\mathrm{HH}}=7.7 \mathrm{~Hz},{ }^{4} \mathrm{~J}_{\mathrm{HH}}=1.3 \mathrm{~Hz}$, $\left.{ }^{4} \mathrm{JHH}_{\mathrm{HH}}=0.5 \mathrm{~Hz}, 1 \mathrm{H}, \mathrm{H}_{16}\right), 7.97\left(\mathrm{dd},{ }^{3} \mathrm{JHH}_{\mathrm{HH}}=8.0 \mathrm{~Hz},{ }^{4} \mathrm{~J}_{\mathrm{HH}}=1.0 \mathrm{~Hz}, 1 \mathrm{H}, \mathrm{H}_{10}\right), 7.78$ (dd, $\left.{ }^{3} \mathrm{JHH}_{\mathrm{HH}}=7.8 \mathrm{~Hz},{ }^{4} \mathrm{HHH}=1.4 \mathrm{~Hz}, 1 \mathrm{H}, \mathrm{H}_{13}\right), 7.67\left(\mathrm{dd},{ }^{3} \mathrm{JHH}_{\mathrm{HH}}=8.6 \mathrm{~Hz},{ }^{4} \mathrm{JHH}_{\mathrm{HH}}=1.0 \mathrm{~Hz}, 1 \mathrm{H}, \mathrm{H}_{8}\right)$, 
$7.60\left(\mathrm{~d},{ }^{3} \mathrm{HHH}=4.1 \mathrm{~Hz}, 1 \mathrm{H}, \mathrm{H} 5\right), 7.19\left(\mathrm{ddd},{ }^{3} \mathrm{JHH}_{\mathrm{HH}}=7.7 \mathrm{~Hz},{ }^{3} \mathrm{JHH}_{\mathrm{HH}}=7.2 \mathrm{~Hz},{ }^{4} \mathrm{JHH}_{\mathrm{HH}}=1.4 \mathrm{~Hz}\right.$, $\left.1 \mathrm{H}, \mathrm{H}_{15}\right), 7.11$ (ddd, $\left.{ }^{3} \mathrm{JHH}_{\mathrm{HH}}=7.8 \mathrm{~Hz},{ }^{3} \mathrm{~J}_{\mathrm{HH}}=7.2 \mathrm{~Hz},{ }^{4} \mathrm{JHH}_{\mathrm{HH}}=1.4 \mathrm{~Hz}, 1 \mathrm{H}, \mathrm{H}_{14}\right), 4.42-4.37$ $\left(\mathrm{m}, 2 \mathrm{H}, \mathrm{H}_{1}\right), 2.13-1.94\left(\mathrm{~m}, 2 \mathrm{H}, \mathrm{H}_{2}\right), 1.05\left(\mathrm{t},{ }^{3} \mathrm{~J}_{\mathrm{HH}}=7.4 \mathrm{~Hz}, 3 \mathrm{H}, \mathrm{H}_{3}\right)$.

${ }^{13} \mathrm{C}-\left\{{ }^{1} \mathrm{H}\right\}-N M R\left(126 \mathrm{MHz}, \mathrm{DMF}-d_{7}\right), \delta(\mathrm{ppm})=166.7\left(\mathrm{C}_{11}\right), 161.1\left(\mathrm{C}_{4}\right), 148.6\left(\mathrm{C}_{7}\right)$, $145.5\left(\mathrm{C}_{12}\right), 144.3\left(\mathrm{C}_{17}\right), 139.2\left(\mathrm{C}_{9}\right), 138.0\left(\mathrm{C}_{6}\right), 134.9\left(\mathrm{C}_{16}\right), 128.9\left(\mathrm{C}_{15}\right), 123.9\left(\mathrm{C}_{13}\right)$, $123.6\left(\mathrm{C}_{14}\right), 114.4\left(\mathrm{C}_{10}\right), 113.6\left(\mathrm{C}_{8}\right), 112.8\left(\mathrm{C}_{5}\right), 59.0\left(\mathrm{C}_{1}\right), 20.3\left(\mathrm{C}_{2}\right), 10.4\left(\mathrm{C}_{3}\right)$.

EM-MS-ESI $\left(\mathrm{MeOH} / \mathrm{CHCl}_{3}, \mathrm{C}_{17} \mathrm{H}_{16} \mathrm{~N}_{3} \mathrm{SPtCl}\right), \mathrm{m} / \mathrm{z}=525.04757$ (found for $[\mathrm{M}+\mathrm{H}]^{+}$), 525.04752 (calcd. for $[\mathrm{M}+\mathrm{H}]^{+}$); 547.02938 (found for $[\mathrm{M}+\mathrm{Na}]^{+}$), 547.02946 (calcd. for $\left.[\mathrm{M}+\mathrm{Na}]^{+}\right)$; 1050.08681 (found for $\left.[2 \mathrm{M}+\mathrm{H}]^{+}\right), 1050.08611$ (calcd. for $\left.[2 \mathrm{M}+\mathrm{H}]^{+}\right)$; 1072.06887 (found for $[2 \mathrm{M}+\mathrm{Na}]^{+}$), 1072.06805 (calcd. for $[2 \mathrm{M}+\mathrm{Na}]^{+}$).<smiles></smiles>

[LPtCl]

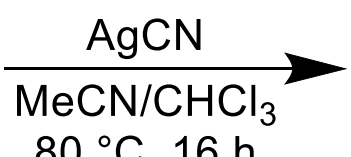

$80{ }^{\circ} \mathrm{C}, 16 \mathrm{~h}$

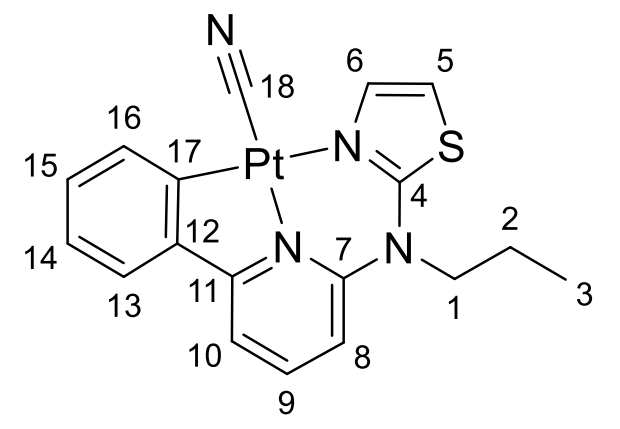

$71 \%$

[LPtCl]

\section{Cyanido-( $\kappa^{3} \mathrm{CNN}-\mathrm{N}$-(6-phenylpyridin-2-yl)- $\mathrm{N}$-propyl-thiazol-2-amino)-platinum(II)}

[PtCN(L)]. [PtCl(L)] (1.0 eq; $60 \mathrm{mg} ; 0.11 \mathrm{mmol})$ and AgCN (1.8 eq; $28 \mathrm{mg} ; 0.21 \mathrm{mmol})$ were suspended and 5 min degassed in a mixture of $\mathrm{CHCl}_{3}(10 \mathrm{~mL})$ and $\mathrm{MeCN}(10 \mathrm{~mL})$ and then heated $16 \mathrm{~h}$ at $80^{\circ} \mathrm{C}$. After reaching room temperature, the solvent was removed under reduced pressure and the residue was purified via column chromatography over silica eluting with a mixture of $\mathrm{DCM} / \mathrm{MeOH}(\mathrm{V}: \mathrm{V}=1: 39$ to $1: 19)$, [PtCN(L)] was obtained as greenish-yellow solid (40 mg; $0.078 \mathrm{mmol} ; 71 \%)$. Pale yellow needle-like crystals were obtained from slow evaporation of a DCM solution.

${ }^{1} \mathrm{H}-\mathrm{NMR}\left(500 \mathrm{MHz}, \mathrm{DMF}-d_{7}\right), \delta(\mathrm{ppm})=8.33\left(\mathrm{dd},{ }^{3} \mathrm{HH}=8.7 \mathrm{~Hz},{ }^{3} J_{\mathrm{HH}}=7.8 \mathrm{~Hz}, 1 \mathrm{H}, \mathrm{H}_{9}\right)$, $8.28\left(\mathrm{~d},{ }^{3} \mathrm{JHH}=4.1 \mathrm{~Hz}, 1 \mathrm{H}, \mathrm{H}_{6}\right), 8.13\left(\mathrm{dd},{ }^{3} \mathrm{JHH}_{\mathrm{HH}}=7.4 \mathrm{~Hz},{ }^{4} \mathrm{JHH}_{\mathrm{HH}}=1.5 \mathrm{~Hz}, 1 \mathrm{H}, \mathrm{H}_{16}\right), 8.07$ $\left(\mathrm{d},{ }^{3} \mathrm{JHH}_{\mathrm{HH}}=7.8 \mathrm{~Hz}, 1 \mathrm{H}, \mathrm{H}_{10}\right), 7.88\left(\mathrm{dd},{ }^{3} \mathrm{JHH}=7.8 \mathrm{~Hz},{ }^{3} \mathrm{JHH}=1.5 \mathrm{~Hz}, 1 \mathrm{H}, \mathrm{H}_{13}\right), 7.81(\mathrm{~d}$, $\left.{ }^{3} \mathrm{HHH}_{\mathrm{HH}}=8.6 \mathrm{~Hz}, 1 \mathrm{H}, \mathrm{H}_{8}\right), 7.69\left(\mathrm{~d},{ }^{3} \mathrm{JHH}_{\mathrm{HH}}=4.1 \mathrm{~Hz}, 1 \mathrm{H}, \mathrm{H}_{5}\right), 7.20\left(\mathrm{td},{ }^{3} \mathrm{~J}_{\mathrm{HH}}=7.3 \mathrm{~Hz}\right.$, $\left.{ }^{4} \mathrm{JHH}_{\mathrm{HH}}=1.5 \mathrm{~Hz}, 1 \mathrm{H}, \mathrm{H}_{14}\right), 7.15\left(\mathrm{td},{ }^{3} \mathrm{~J}_{\mathrm{HH}}=7.4 \mathrm{~Hz},{ }^{4} \mathrm{JHH}_{\mathrm{HH}}=1.5 \mathrm{~Hz}, 1 \mathrm{H}, \mathrm{H}_{15}\right), 4.56-4.26(\mathrm{~m}$, $\left.2 \mathrm{H}, \mathrm{H}_{1}\right), 2.20-1.95\left(\mathrm{~m}, 2 \mathrm{H}, \mathrm{H}_{2}\right), 1.09\left(\mathrm{t},{ }^{3} \mathrm{~J}_{\mathrm{HH}}=7.4 \mathrm{~Hz}, 3 \mathrm{H}, \mathrm{H}_{3}\right)$.

${ }^{13} \mathrm{C}-\left\{{ }^{1} \mathrm{H}\right\}-N M R\left(126 \mathrm{MHz}, \mathrm{DMF}-d_{7}\right), \delta(\mathrm{ppm})=165.9\left(\mathrm{C}_{11}\right), 161.7\left(\mathrm{C}_{4}\right), 148.5\left(\mathrm{C}_{7}\right)$, $145.1\left(\mathrm{C}_{17}\right), 143.4\left(\mathrm{C}_{12}\right), 142.3\left(\mathrm{C}_{6}\right), 140.9\left(\mathrm{C}_{9}\right), 138.8\left(\mathrm{C}_{16}\right), 130.2\left(\mathrm{C}_{14}\right), 124.5\left(\mathrm{C}_{13}\right)$, $123.9\left(\mathrm{C}_{15}\right), 114.5\left(\mathrm{C}_{10}\right), 114.3\left(\mathrm{C}_{5}\right), 113.1\left(\mathrm{C}_{8}\right), 59.0\left(\mathrm{C}_{1}\right), 20.0\left(\mathrm{C}_{2}\right), \quad 10.4\left(\mathrm{C}_{3}\right)$. Quaternary carbon signals missing in the ${ }^{13} \mathrm{C}-\left\{{ }^{1} \mathrm{H}\right\}-\mathrm{NMR}(1 \mathrm{D})$ and taken from 2Dspectra/experiments, $\mathrm{C}_{18} \equiv \mathrm{N}$ missing.

EM-MS-ESI ( $\mathrm{MeOH} / \mathrm{CHCl}_{3}, \mathrm{C}_{18} \mathrm{H}_{16} \mathrm{~N}_{4} \mathrm{SPt}$ ), $\mathrm{m} / \mathrm{z}=516.08190$ (found for [M+H] ${ }^{+}$), (calcd. for $\left.516.08174[\mathrm{M}+\mathrm{H}]^{+}\right) ; 538.06387$ (found for $[\mathrm{M}+\mathrm{Na}]^{+}$), 538.06356 (calcd. for $[\mathrm{M}+\mathrm{Na}]^{+}$).

IR (ATR): $\tilde{\text { U }}\left(\mathrm{cm}^{-1}\right)=2120(\mathrm{C} \equiv \mathrm{N})$. 
Section S3: NMR spectra of 1, 2a, 2b, LH, $[\mathrm{PtCl}(\mathrm{L})]$ and $[\mathrm{PtCN}(\mathrm{L})]$

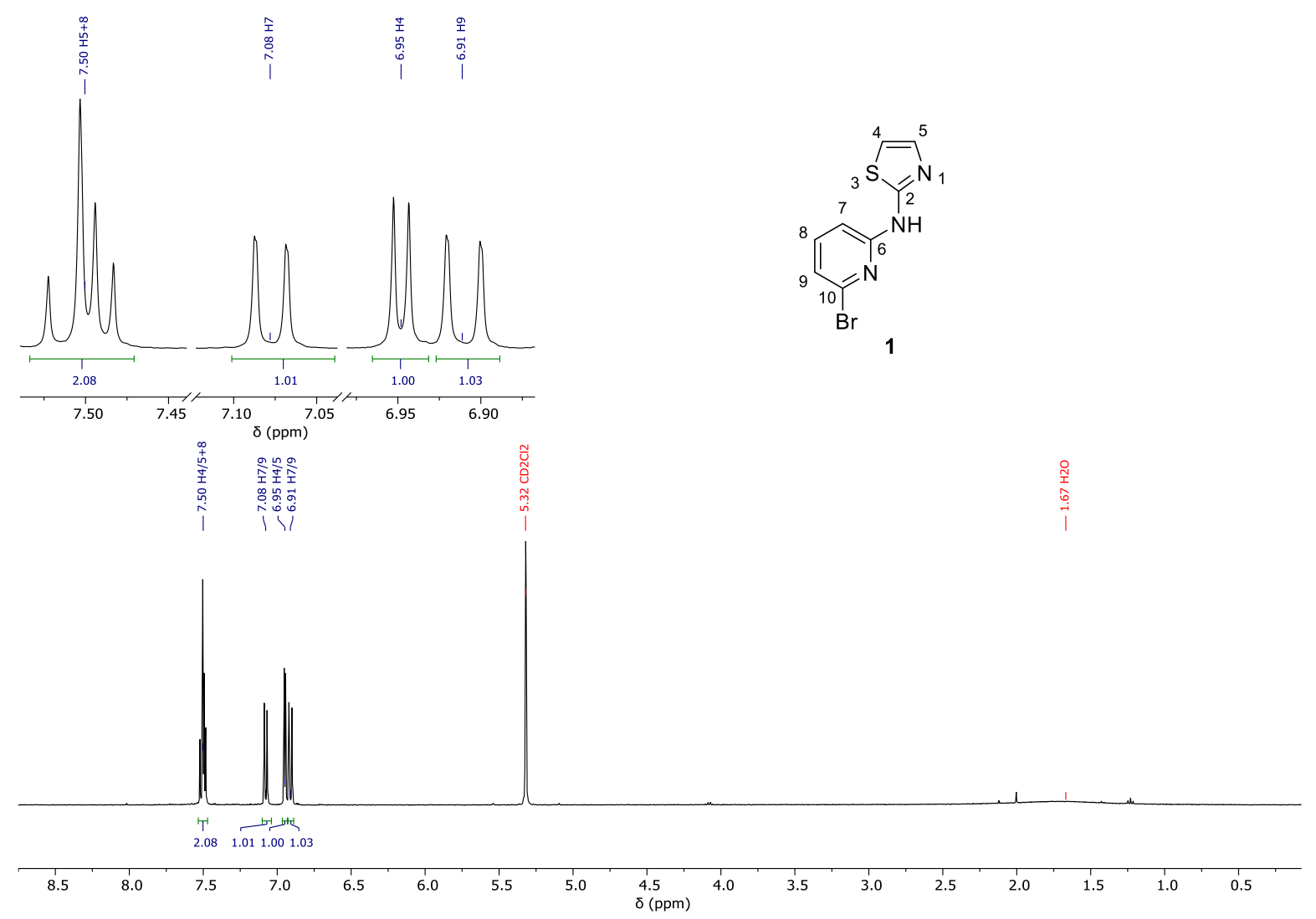

Figure S1. ${ }^{1} \mathrm{H}-\mathrm{NMR}$ spectrum $\left(400 \mathrm{MHz}, \mathrm{DCM}-\mathrm{d}_{2}\right)$ of 1.

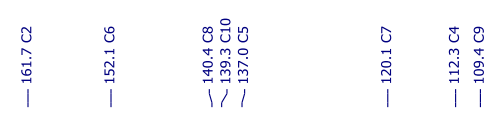

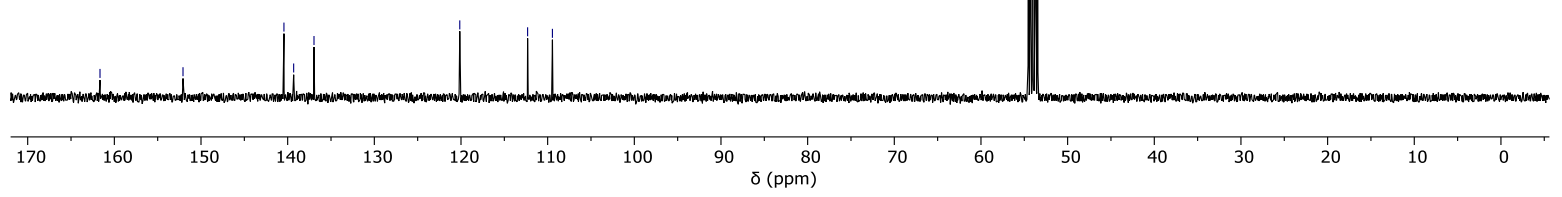

Figure S2. ${ }^{13} \mathrm{C}-\left\{{ }^{1} \mathrm{H}\right\}-\mathrm{NMR}$ spectrum $\left(101 \mathrm{MHz}, \mathrm{DCM}-\mathrm{d}_{2}\right)$ of $\mathbf{1}$. 


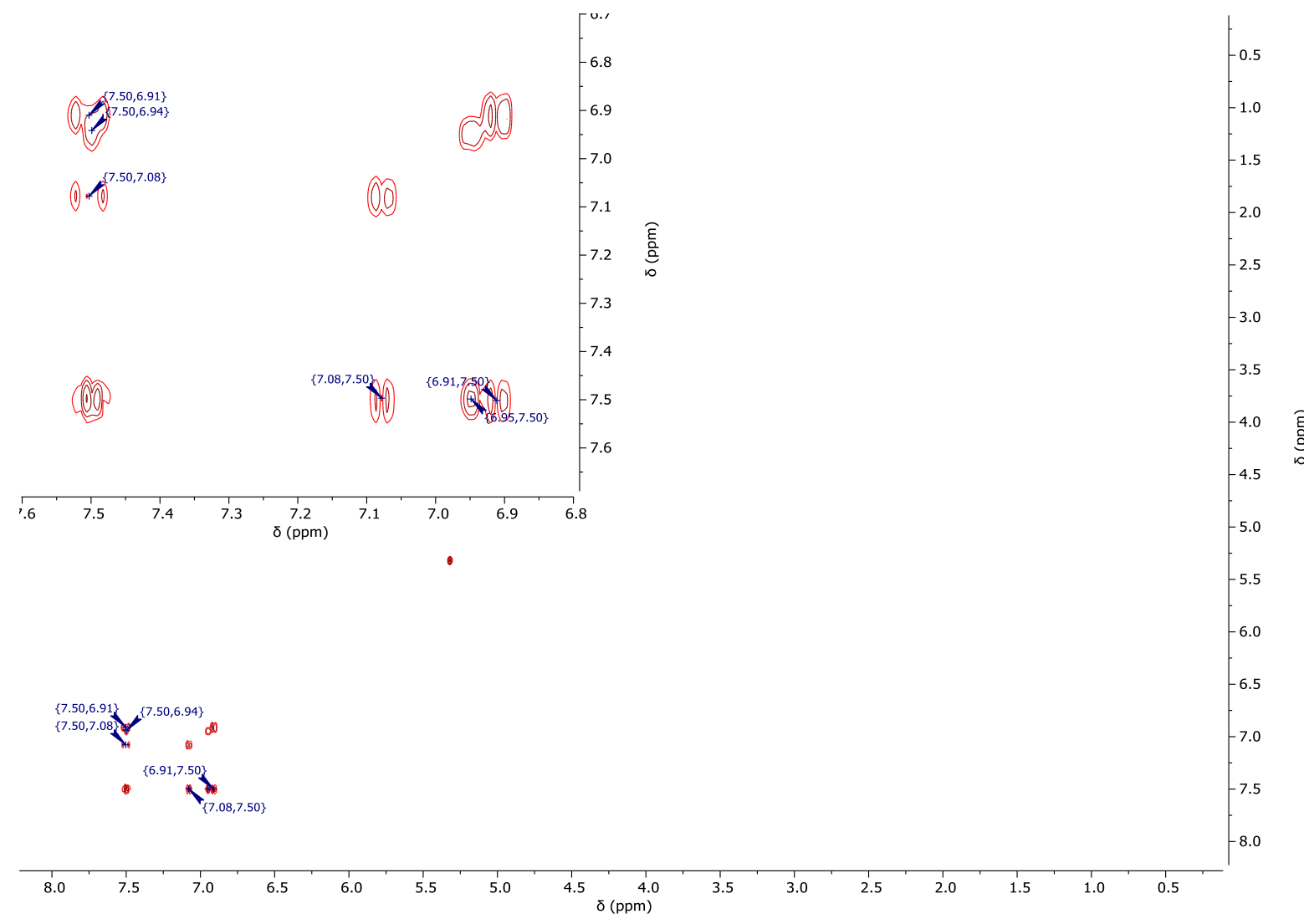

Figure S3. ${ }^{1} \mathrm{H} /{ }^{1} \mathrm{H}-\mathrm{COSY}-N M R$ spectrum $\left(400 \mathrm{MHz} / 400 \mathrm{MHz}, \mathrm{DCM}-\mathrm{d}_{2}\right)$ of 1.

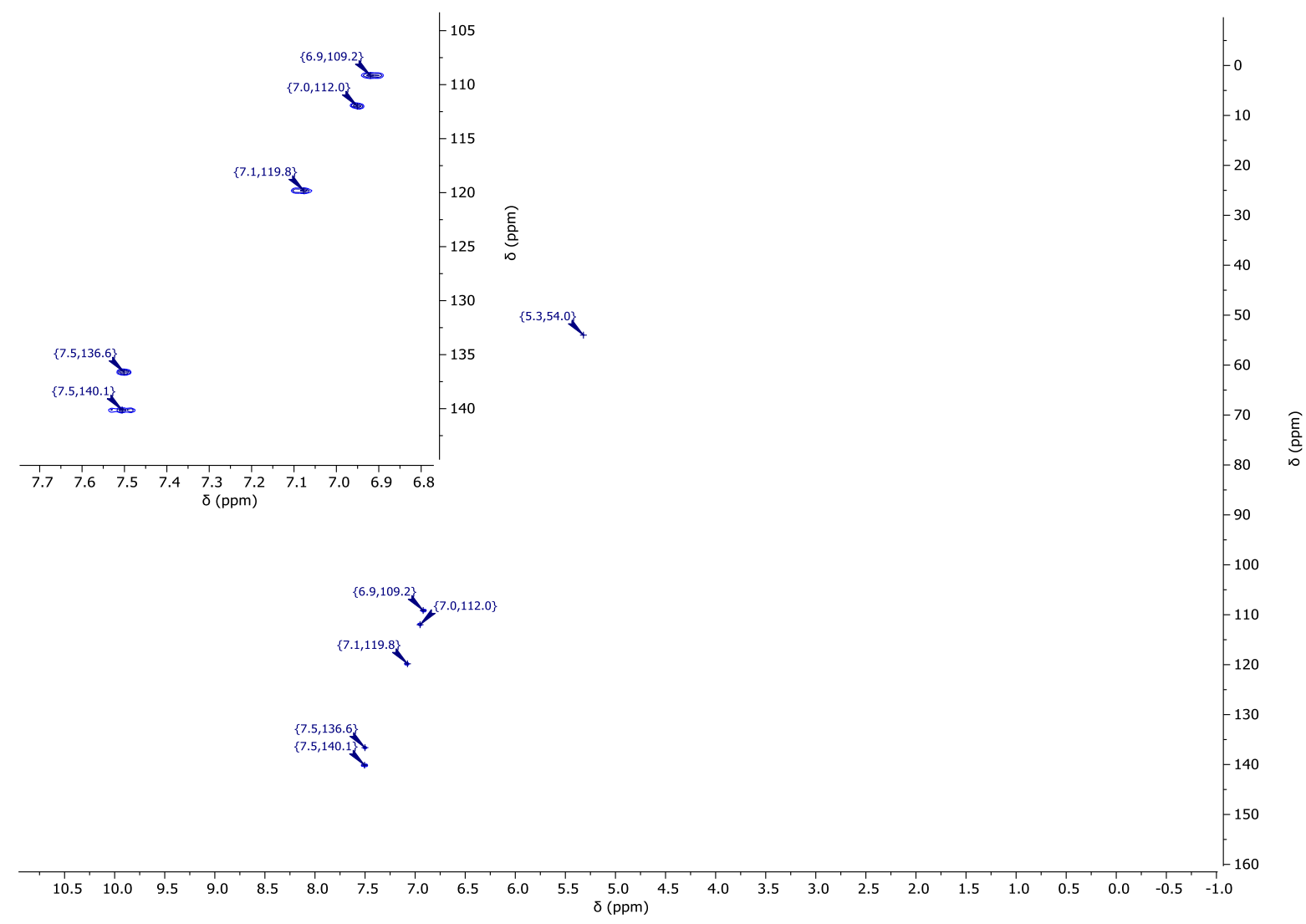

Figure S4. ${ }^{1} \mathrm{H} /{ }^{13} \mathrm{C}-\mathrm{gHSQC}-\mathrm{NMR}$ spectrum $\left(400 \mathrm{MHz} / 101 \mathrm{MHz}, \mathrm{DCM}-\mathrm{d}_{2}\right)$ of 1. 


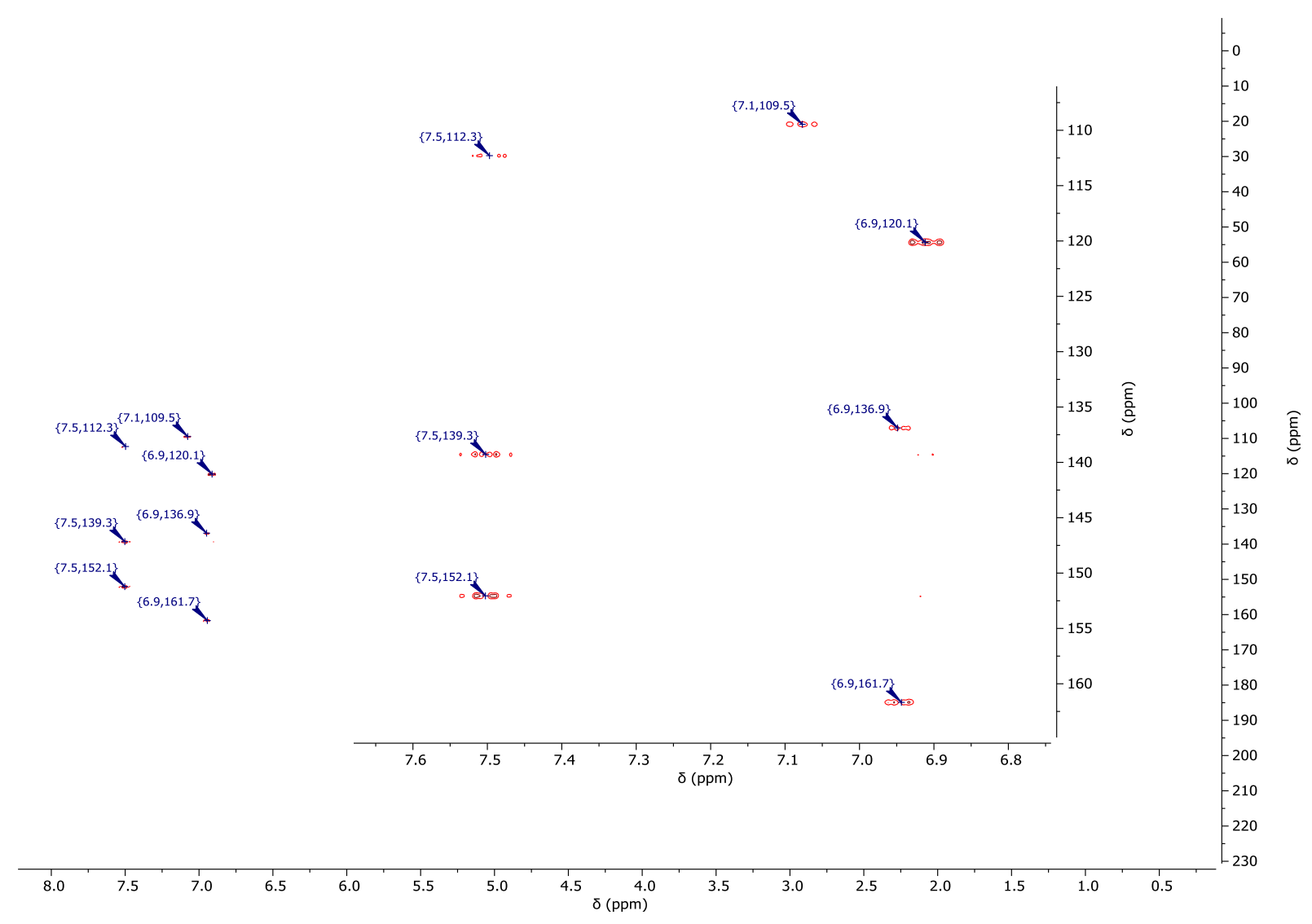

Figure S5. ${ }^{1} \mathrm{H} /{ }^{13} \mathrm{C}-\mathrm{gHMBC}-\mathrm{NMR}$ spectrum $\left(400 \mathrm{MHz} / 101 \mathrm{MHz}, \mathrm{DCM}-\mathrm{d}_{2}\right)$ of 1.
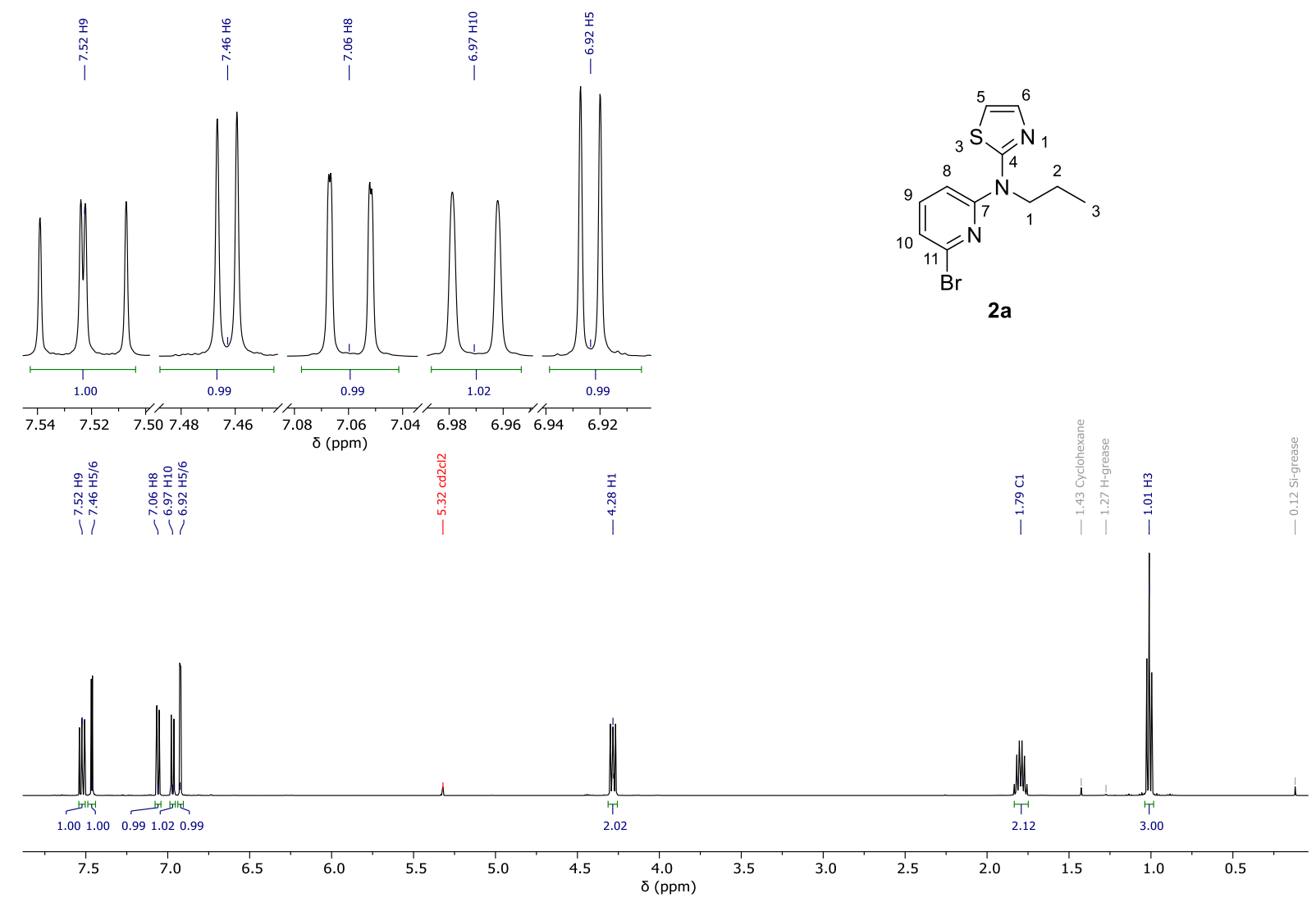

Figure S6. ${ }^{1} \mathrm{H}-\mathrm{NMR}$ spectrum $\left(400 \mathrm{MHz}, \mathrm{DCM}-\mathrm{d}_{2}\right)$ of $\mathbf{2 a}$. 


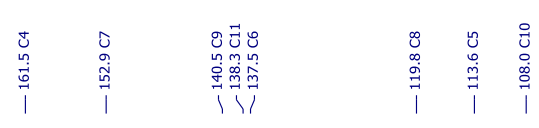
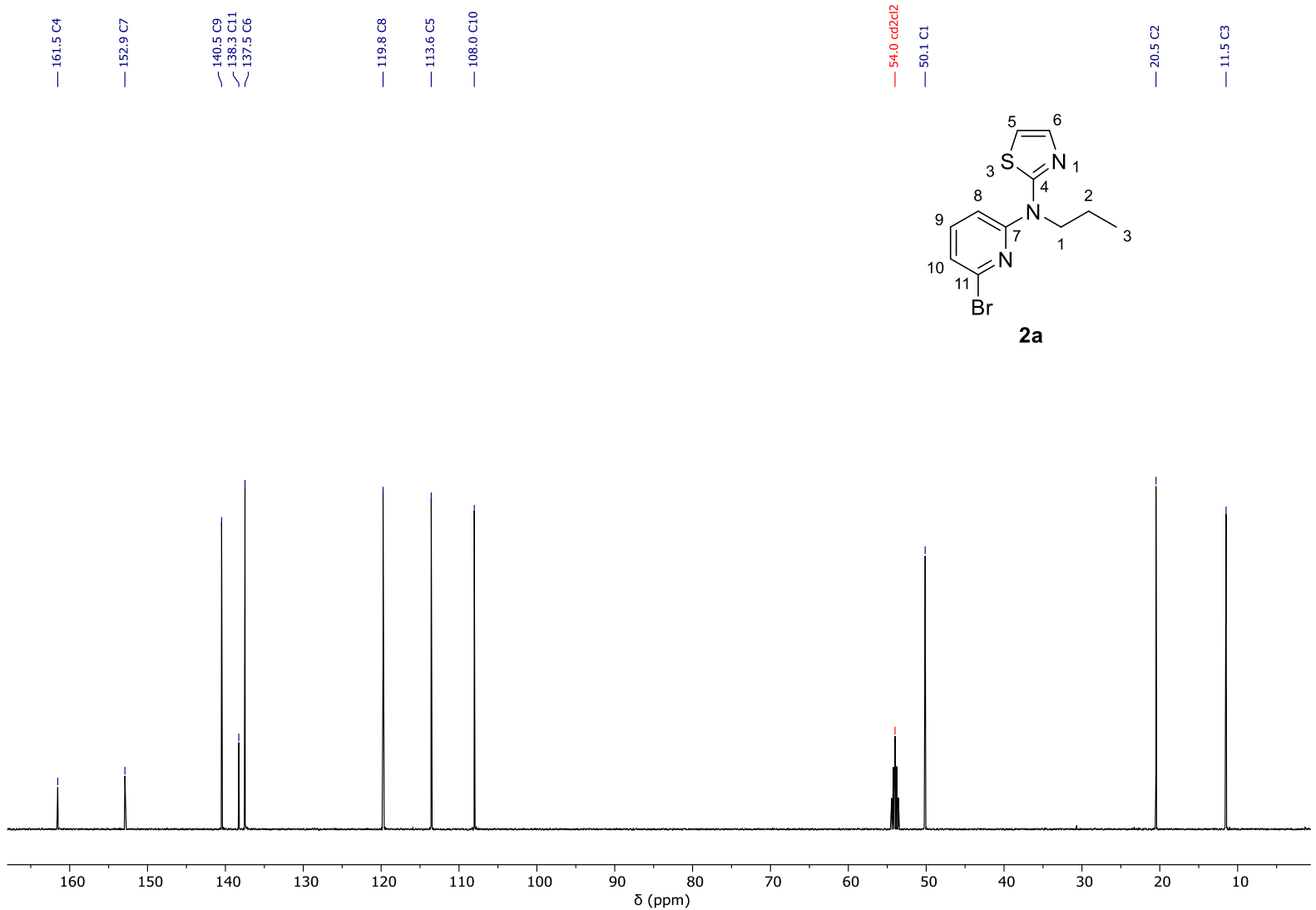

Figure S7. ${ }^{13} \mathrm{C}-\left\{{ }^{1} \mathrm{H}\right\}-\mathrm{NMR}$ spectrum $\left(101 \mathrm{MHz}, \mathrm{DCM}-\mathrm{d}_{2}\right)$ of $\mathbf{2 a}$.
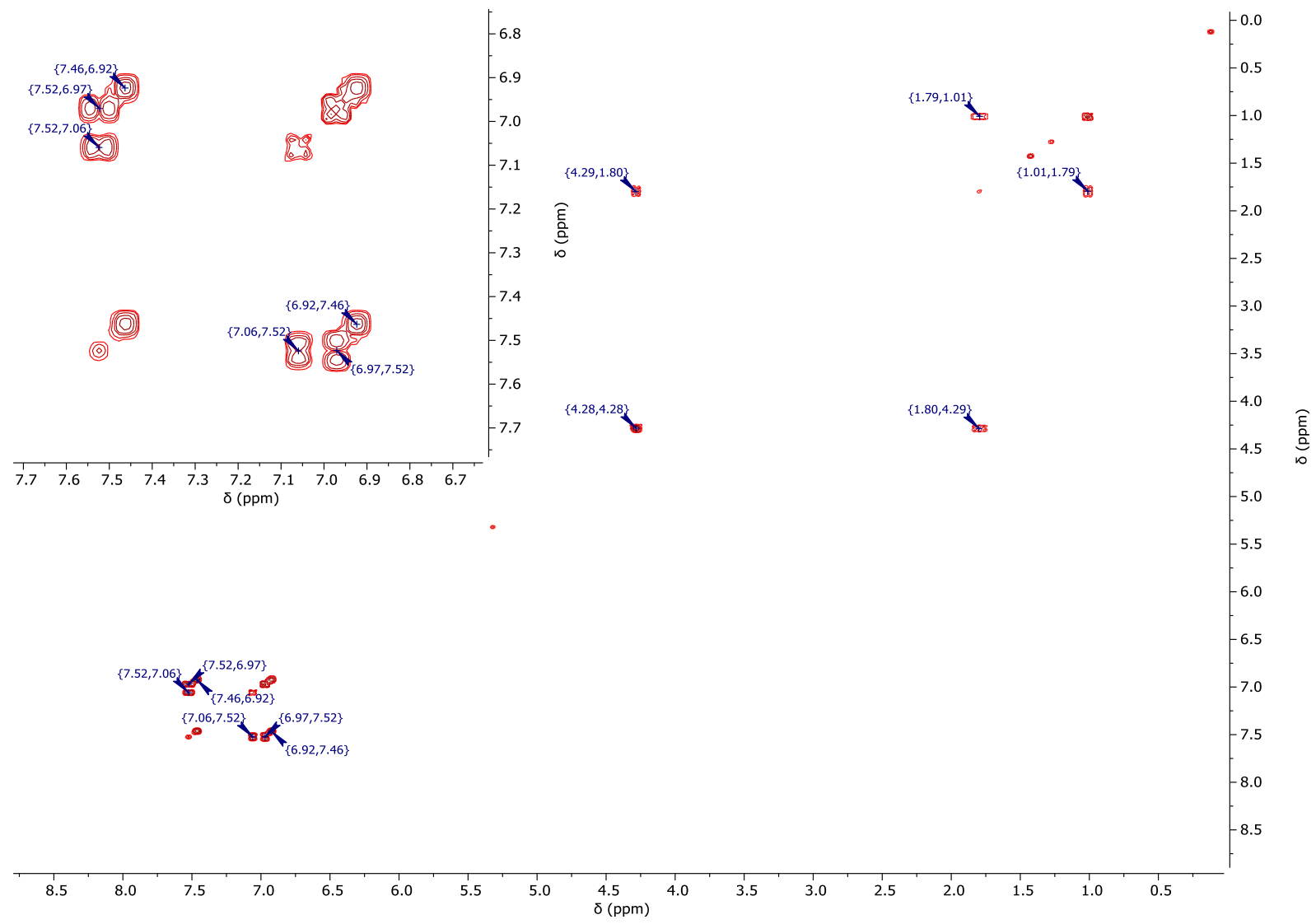

Figure S8. ${ }^{1} \mathrm{H} /{ }^{1} \mathrm{H}-\mathrm{COSY}-\mathrm{NMR}$ spectrum (400 MHz/400 MHz, DCM-d 2 ) of $\mathbf{2 a}$. 


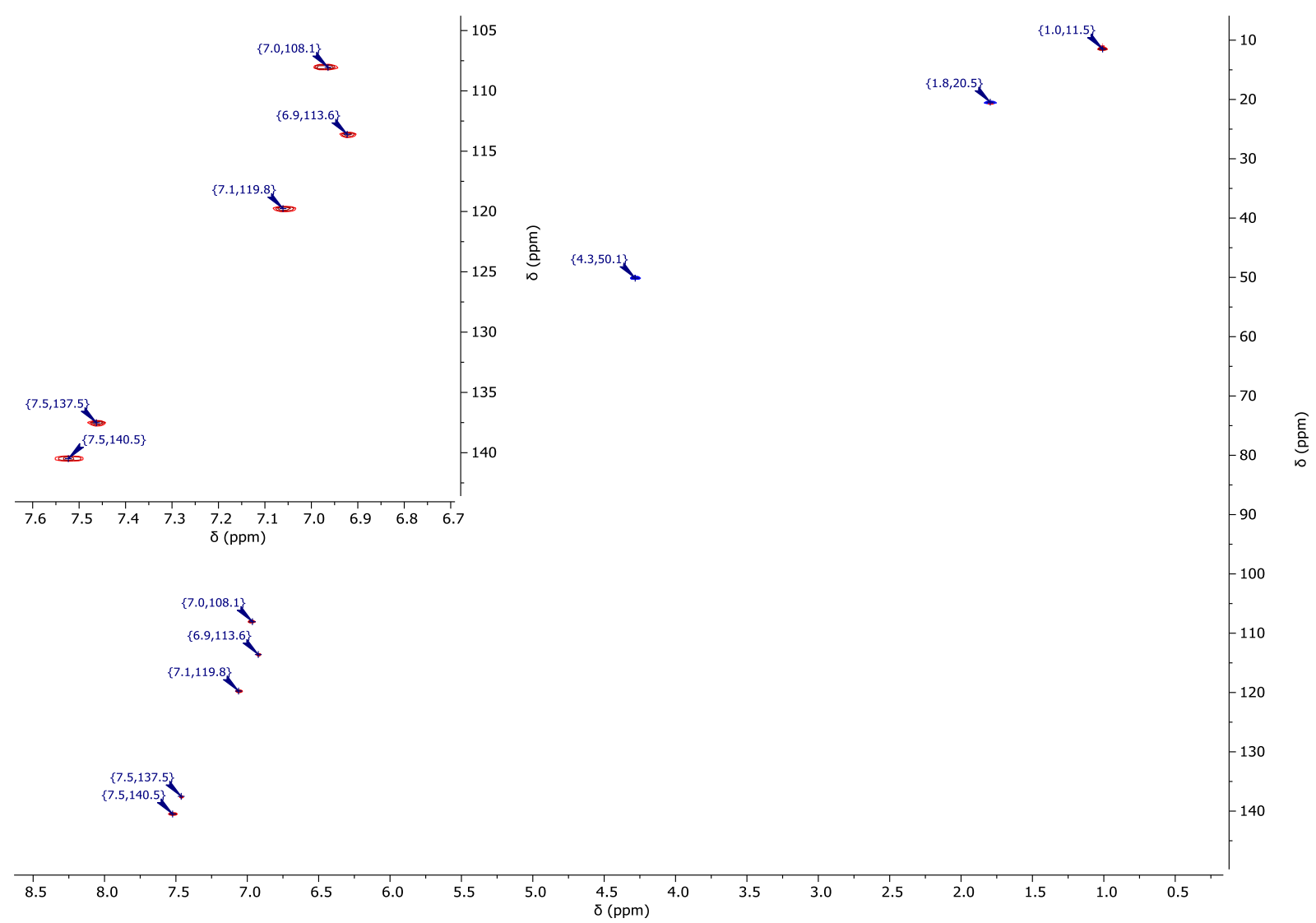

Figure S9. ${ }^{1} \mathrm{H} /{ }^{13} \mathrm{C}-\mathrm{gHSQC}-\mathrm{NMR}$ spectrum $\left(400 \mathrm{MHz} / 101 \mathrm{MHz}, \mathrm{DCM}-\mathrm{d}_{2}\right)$ of $\mathbf{2 a}$.

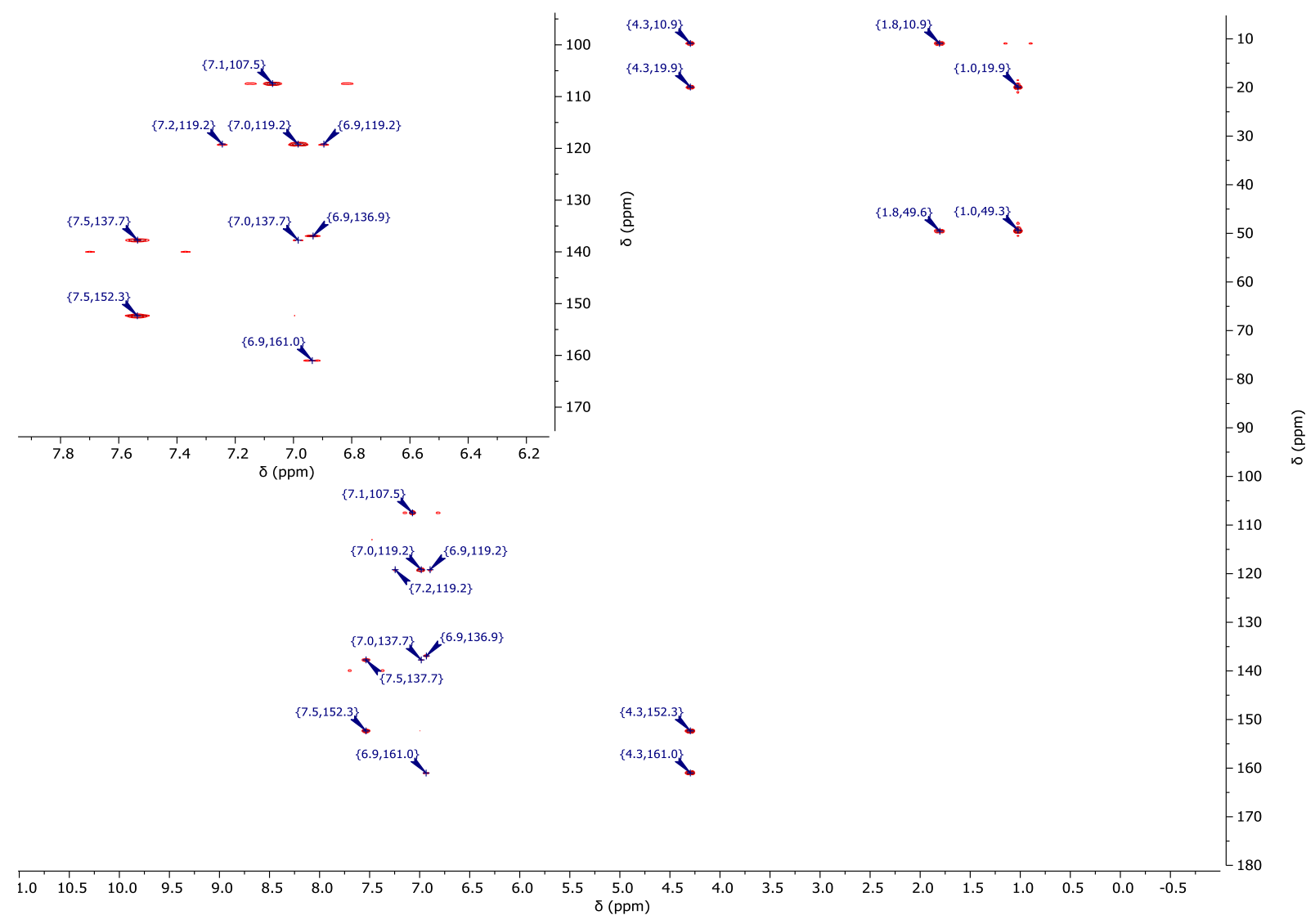

Figure S10. ${ }^{1} \mathrm{H} /{ }^{13} \mathrm{C}-\mathrm{gHMBC}-\mathrm{NMR}$ spectrum $\left(400 \mathrm{MHz} / 101 \mathrm{MHz}, \mathrm{DCM}-\mathrm{d}_{2}\right)$ of $\mathbf{2 a}$. 

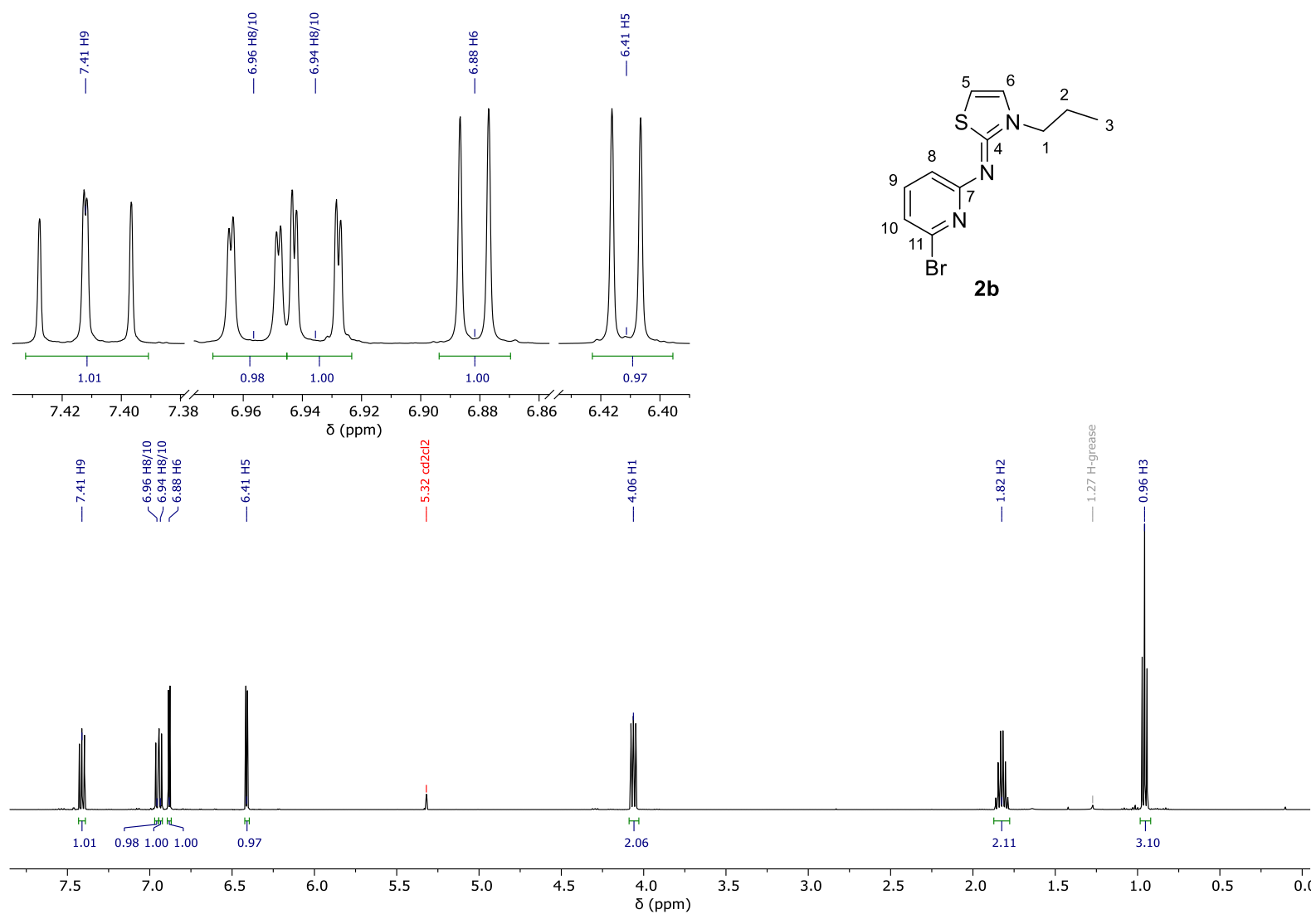

Figure S11. ${ }^{1} \mathrm{H}-\mathrm{NMR}$ spectrum $\left(400 \mathrm{MHz}, \mathrm{DCM}-\mathrm{d}_{2}\right)$ of $\mathbf{2} \mathbf{b}$.

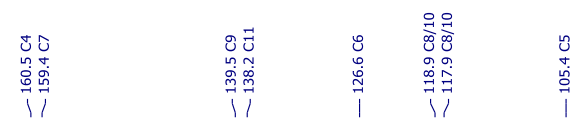
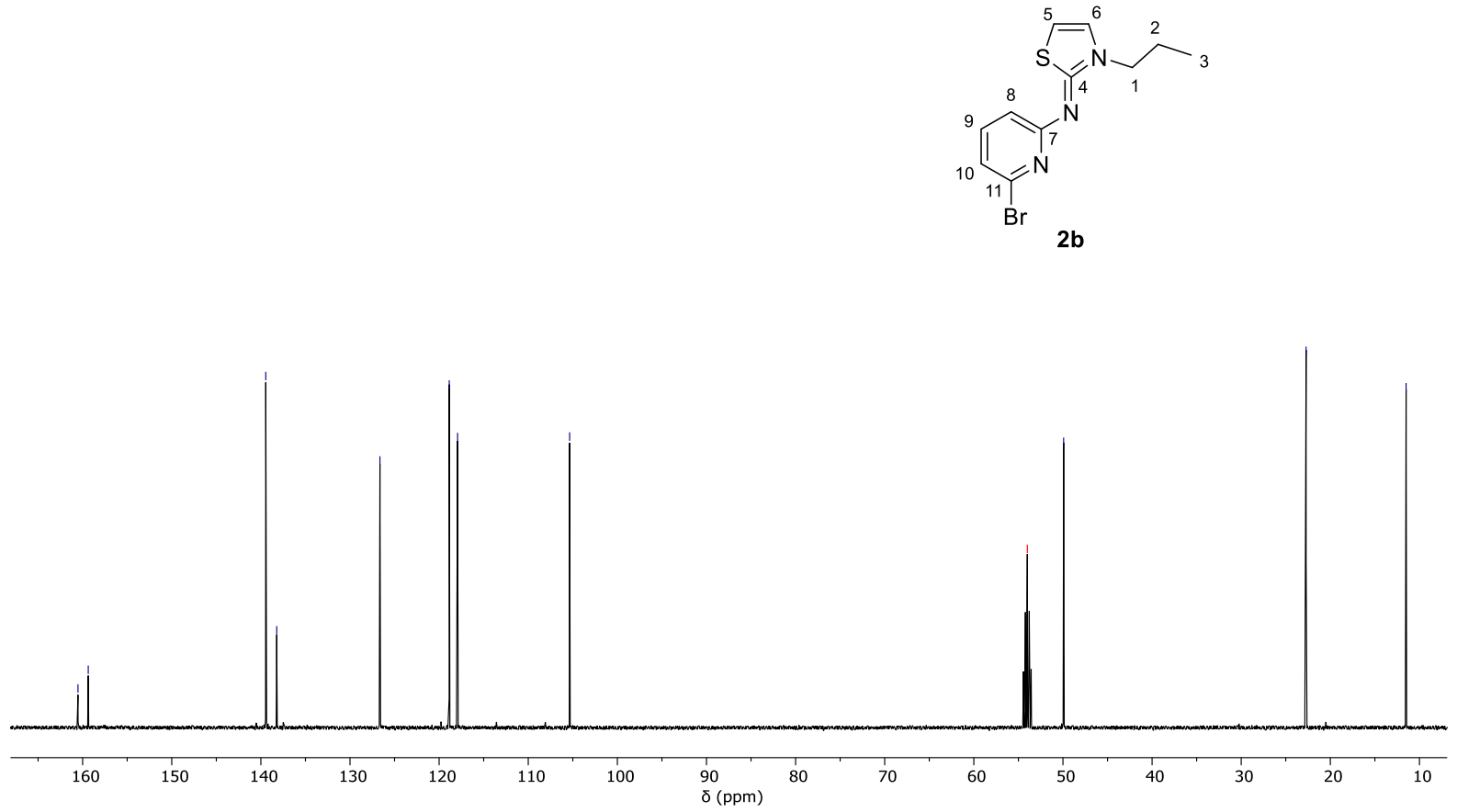

Figure S12. ${ }^{13} \mathrm{C}-\left\{{ }^{1} \mathrm{H}\right\}-\mathrm{NMR}$ spectrum $\left(101 \mathrm{MHz}, \mathrm{DCM}-\mathrm{d}_{2}\right)$ of $\mathbf{2 b}$. 


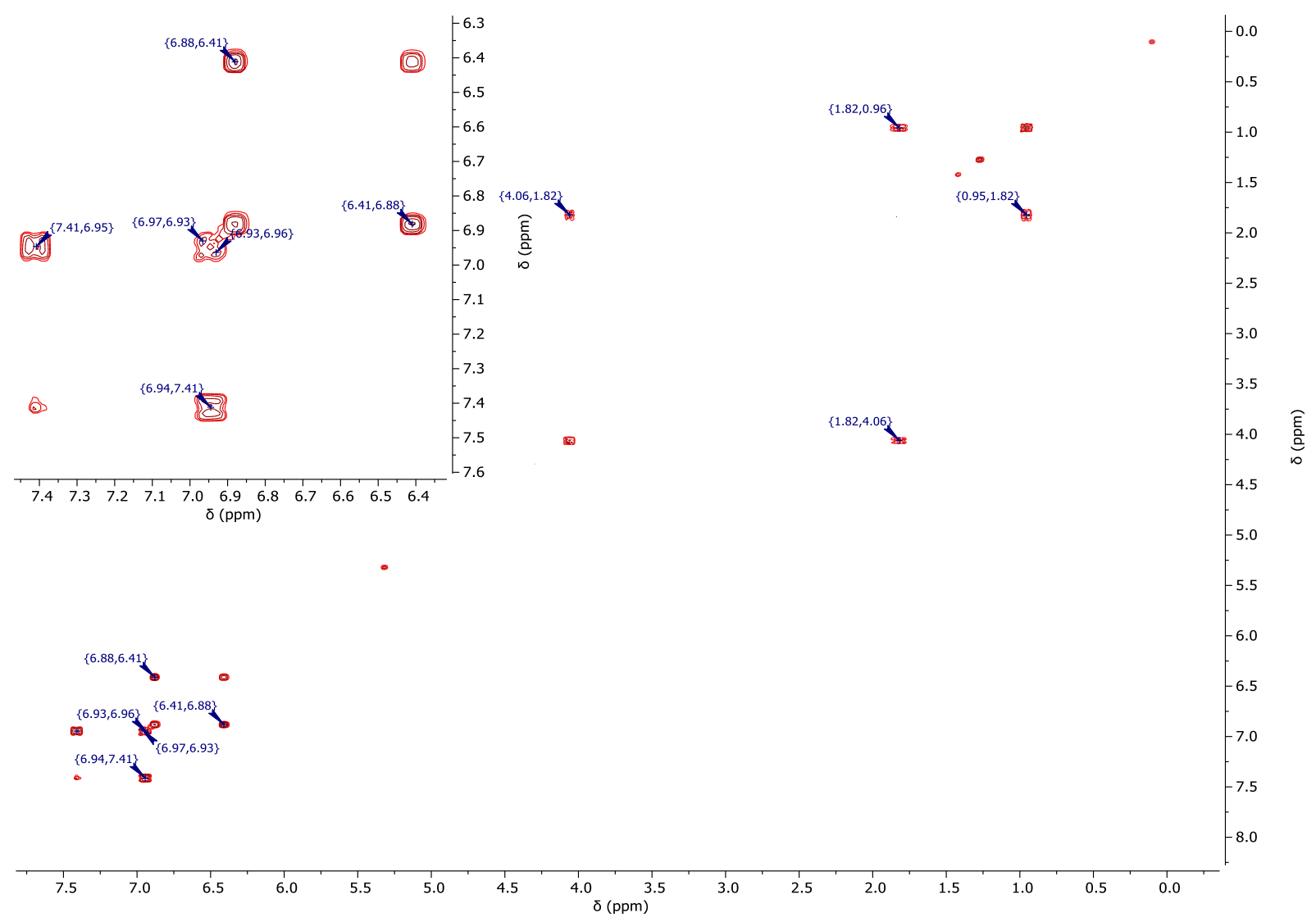

Figure S13. ${ }^{1} \mathrm{H} /{ }^{1} \mathrm{H}-\mathrm{COSY}-\mathrm{NMR}$ spectrum $\left(400 \mathrm{MHz} / 400 \mathrm{MHz}, \mathrm{DCM}-\mathrm{d}_{2}\right)$ of $\mathbf{2 b}$.

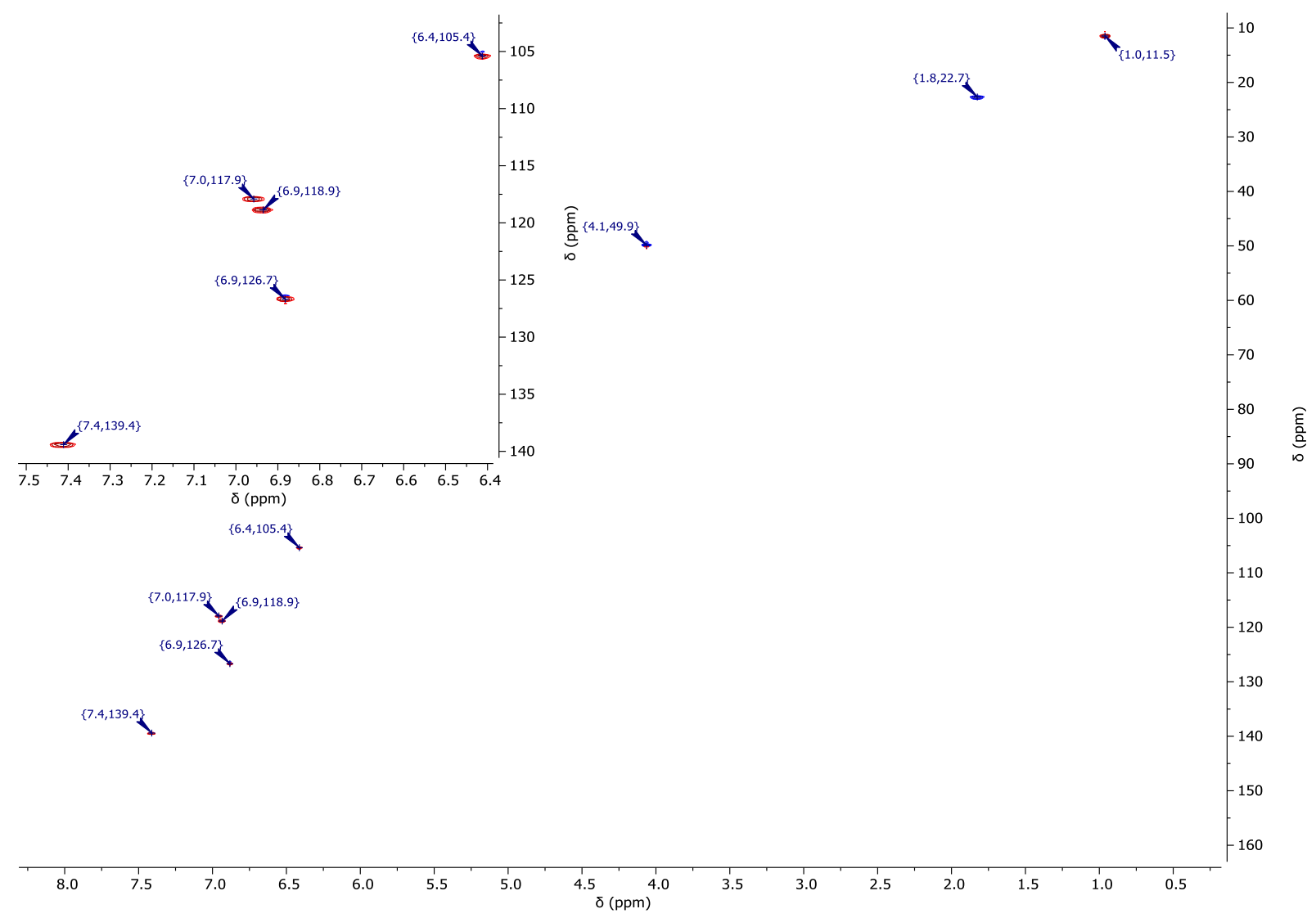

Figure S14. ${ }^{1} \mathrm{H} /{ }^{13} \mathrm{C}$-gHSQC-NMR spectrum (400 MHz/101 MHz, DCM- $\left.\mathrm{d}_{2}\right)$ of $\mathbf{2 b}$. 


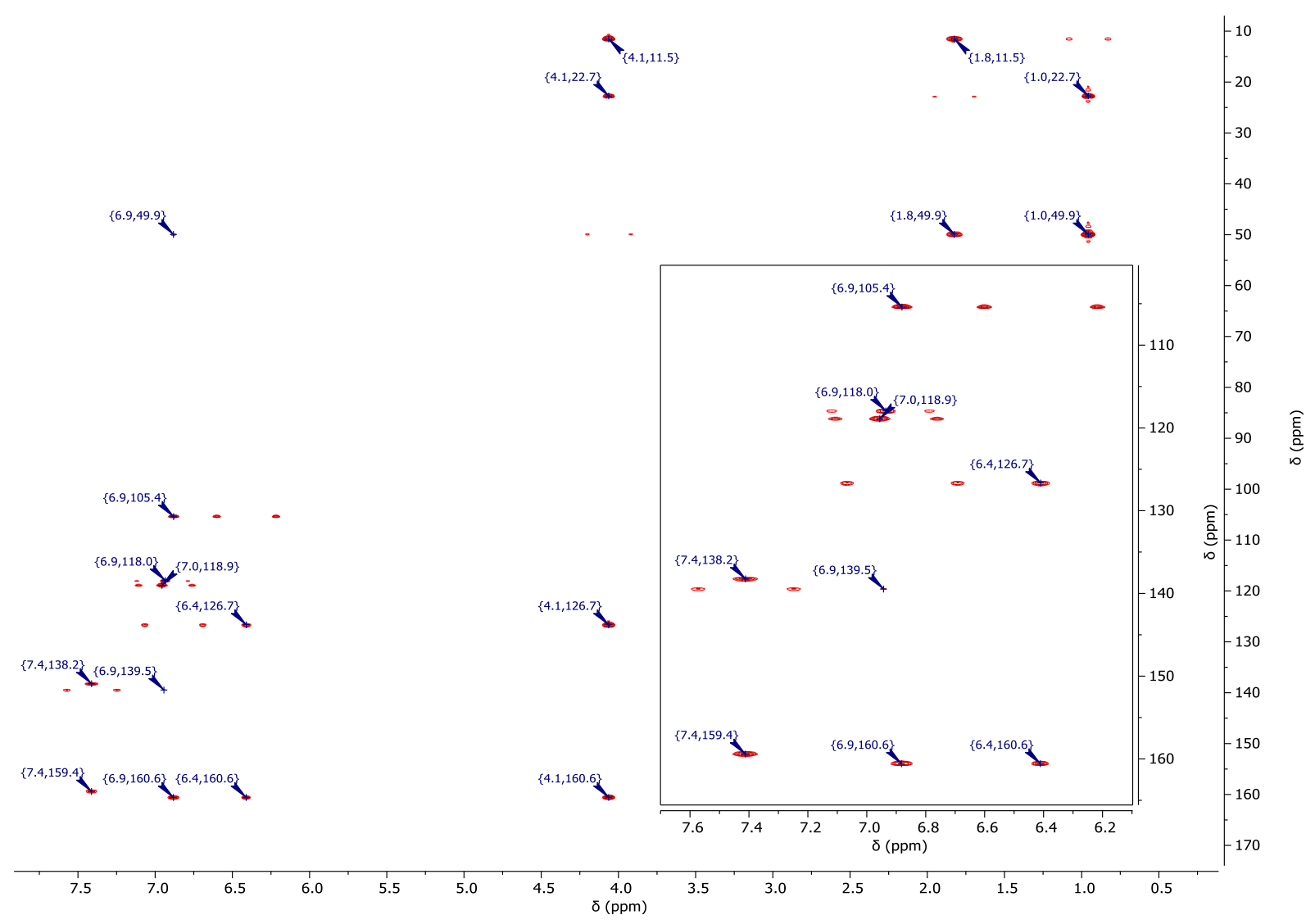

Figure S15. ${ }^{1} \mathrm{H} /{ }^{13} \mathrm{C}-\mathrm{gHMBC}-\mathrm{NMR}$ spectrum $\left(400 \mathrm{MHz} / 101 \mathrm{MHz}, \mathrm{DCM}-\mathrm{d}_{2}\right)$ of $\mathbf{2 b}$.

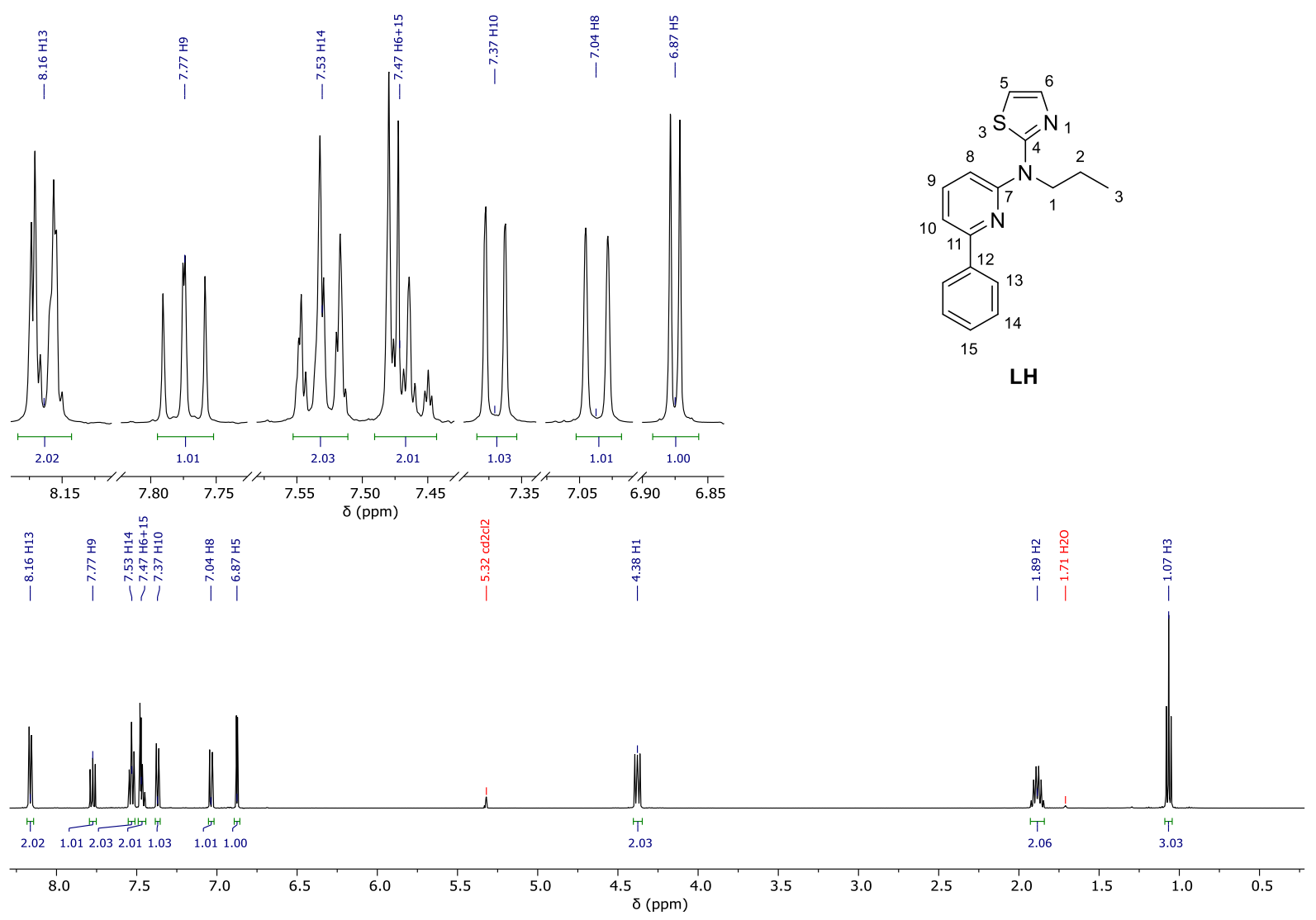

Figure S16. ${ }^{1} \mathrm{H}-\mathrm{NMR}$ spectrum $\left(500 \mathrm{MHz}, \mathrm{DCM}-\mathrm{d}_{2}\right)$ of the ligand precursor $\mathbf{L H}$. 


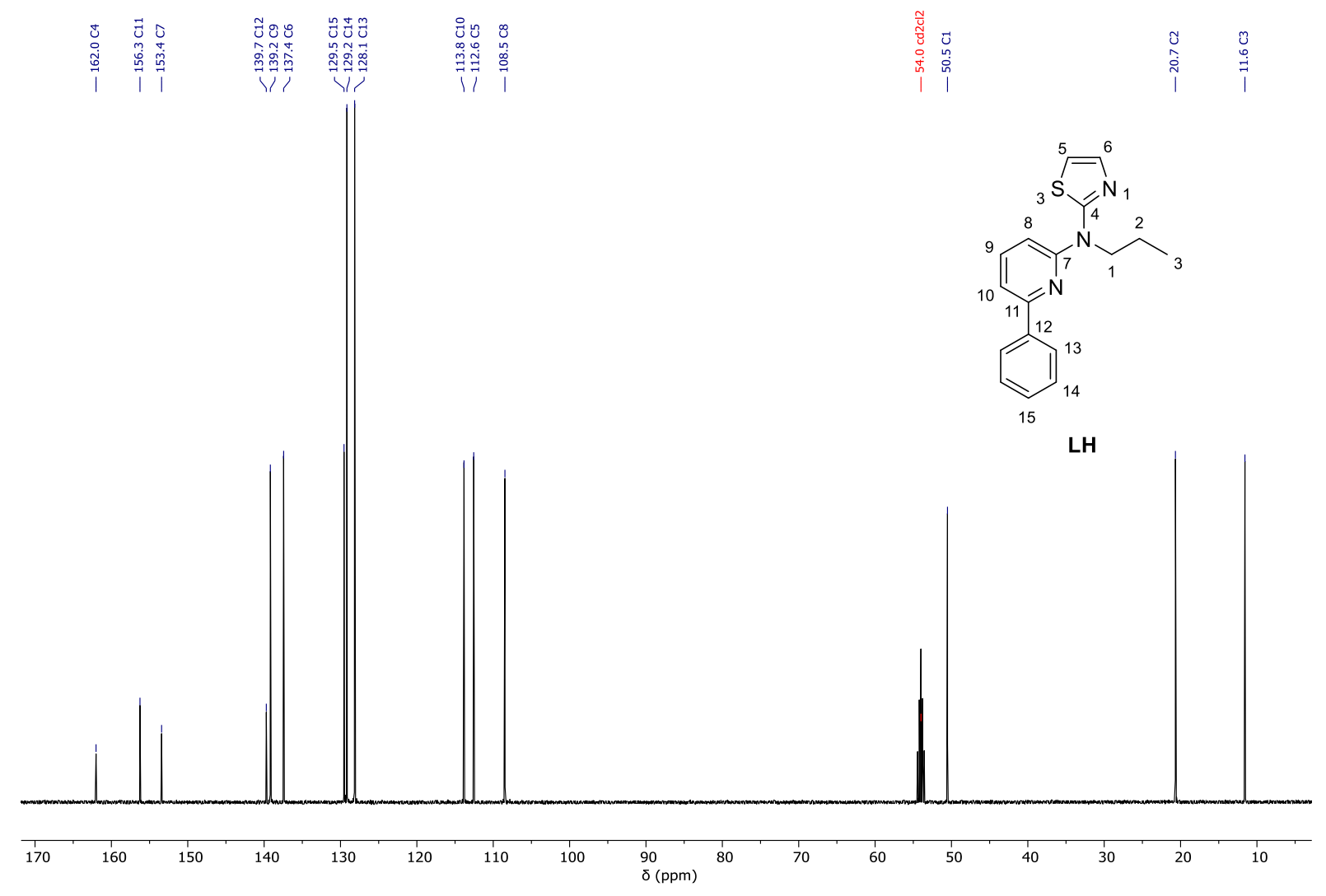

Figure S17. ${ }^{13} \mathrm{C}-\left\{{ }^{1} \mathrm{H}\right\}-N M R$ spectrum $\left(126 \mathrm{MHz}, \mathrm{DCM}-\mathrm{d}_{2}\right)$ of the ligand precursor $\mathbf{L H}$.

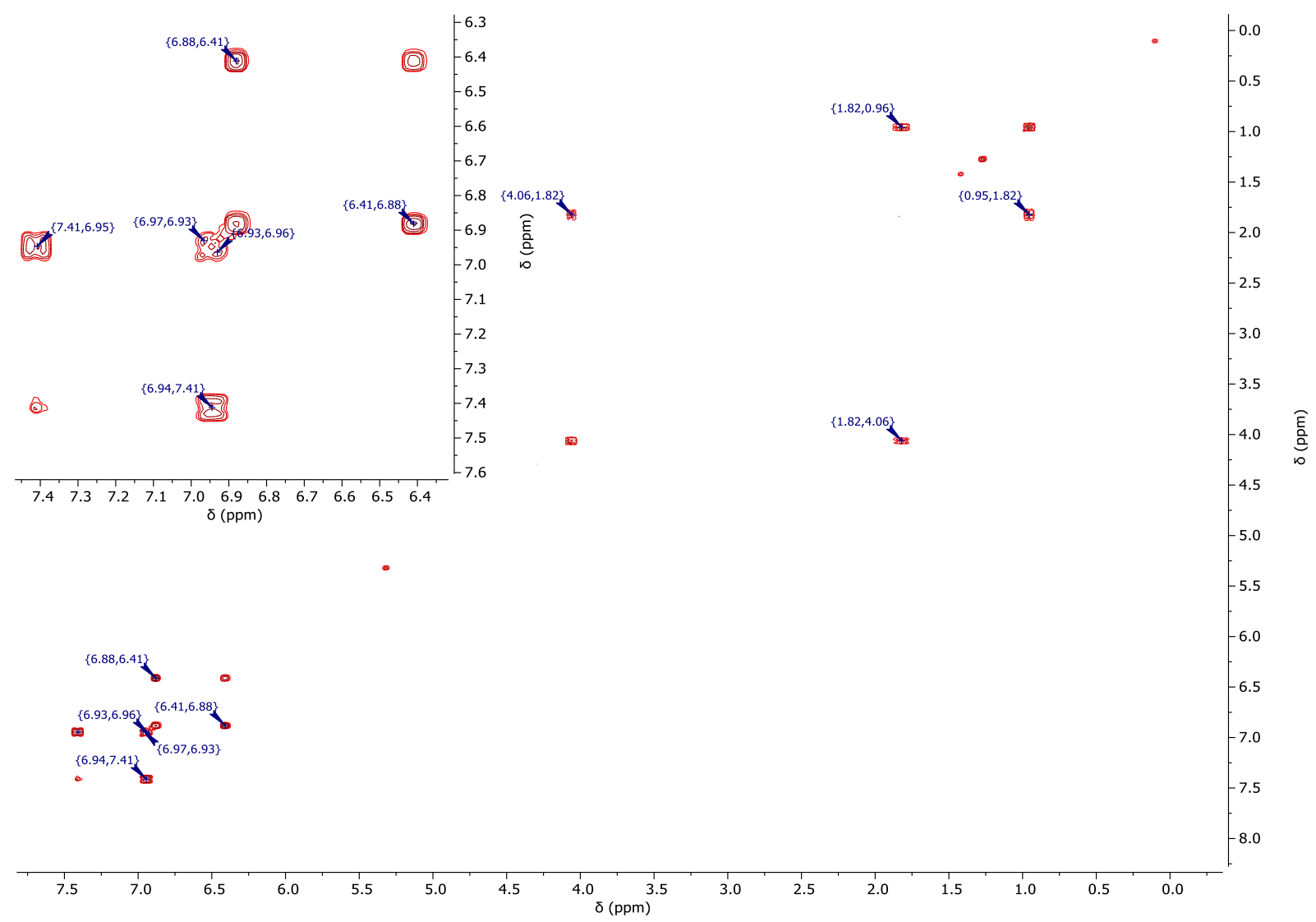

Figure S18. ${ }^{1} \mathrm{H} /{ }^{1} \mathrm{H}-\mathrm{COSY}-N M R$ spectrum $\left(500 \mathrm{MHz} / 500 \mathrm{MHz}, \mathrm{DCM}-\mathrm{d}_{2}\right)$ of the ligand precursor $\mathbf{L H}$. 


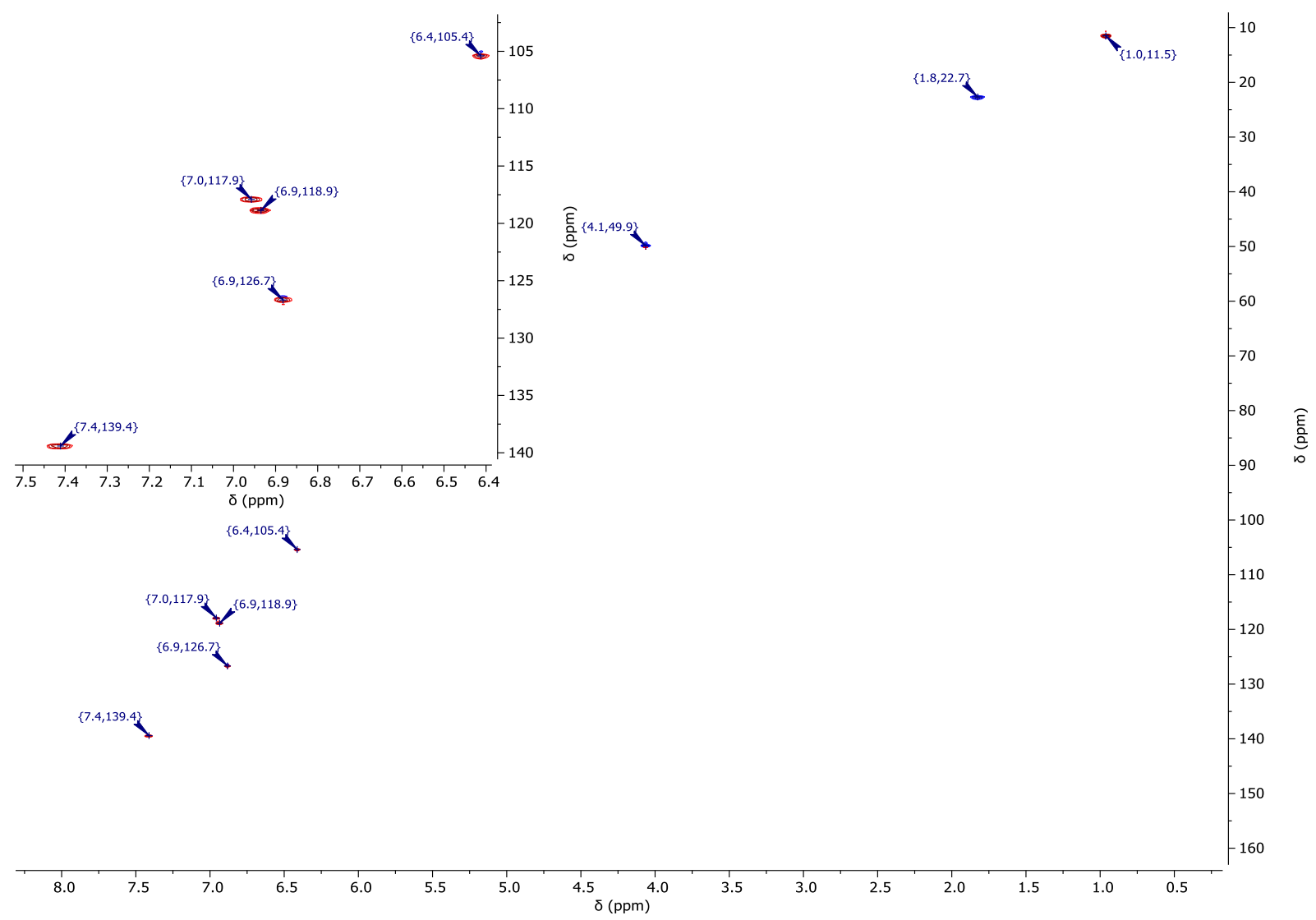

Figure S19. ${ }^{1} \mathrm{H} /{ }^{13} \mathrm{C}-\mathrm{gHSQC}-\mathrm{NMR}$ spectrum $\left(500 \mathrm{MHz} / 126 \mathrm{MHz}, \mathrm{DCM}-\mathrm{d}_{2}\right)$ of the ligand precursor $\mathbf{L H}$.

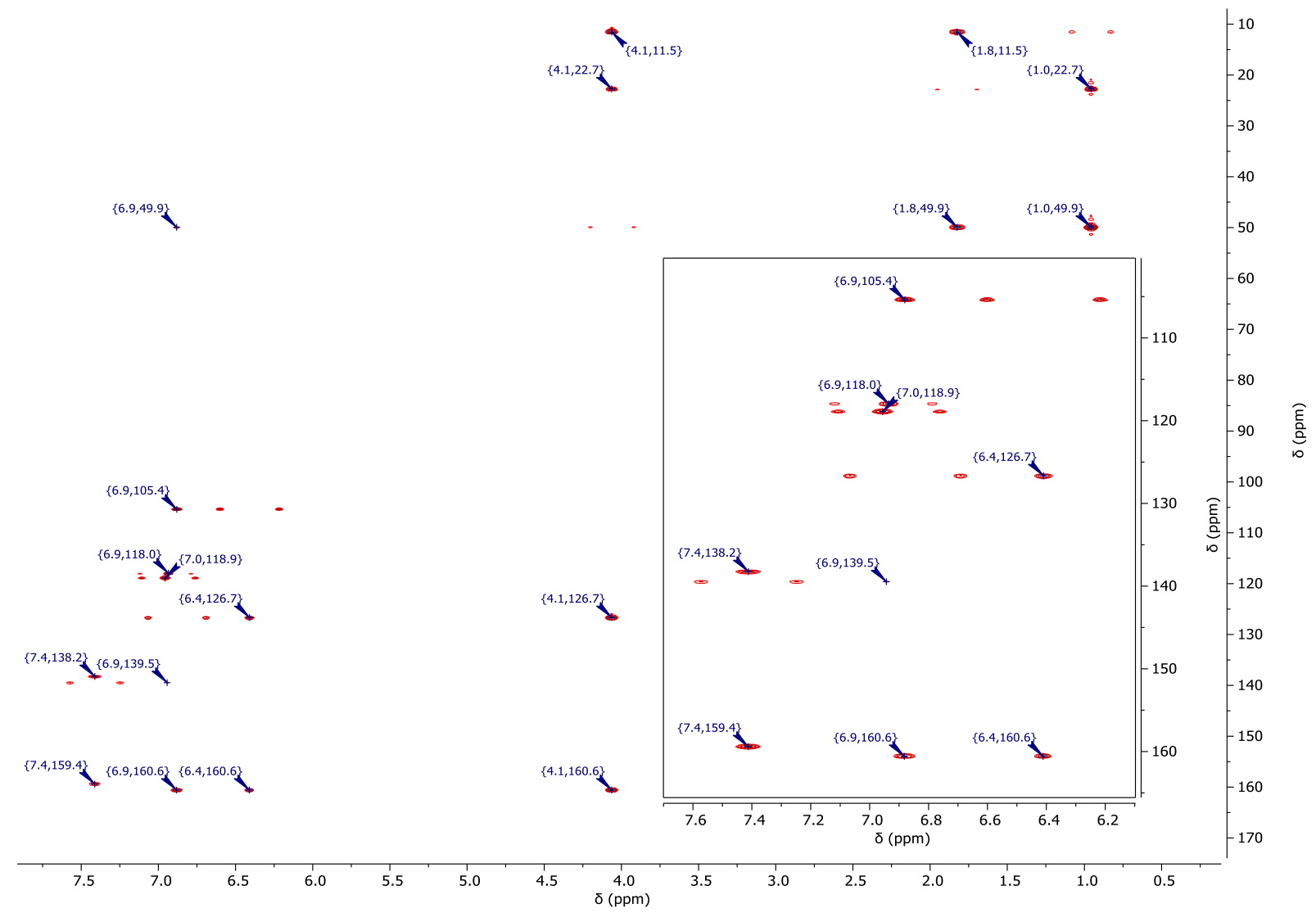

Figure S20. ${ }^{1} \mathrm{H} /{ }^{13} \mathrm{C}$-gHMBC-NMR spectrum $\left(500 \mathrm{MHz} / 126 \mathrm{MHz}, \mathrm{DCM}-\mathrm{d}_{2}\right)$ of the ligand precursor $\mathbf{L H}$. 


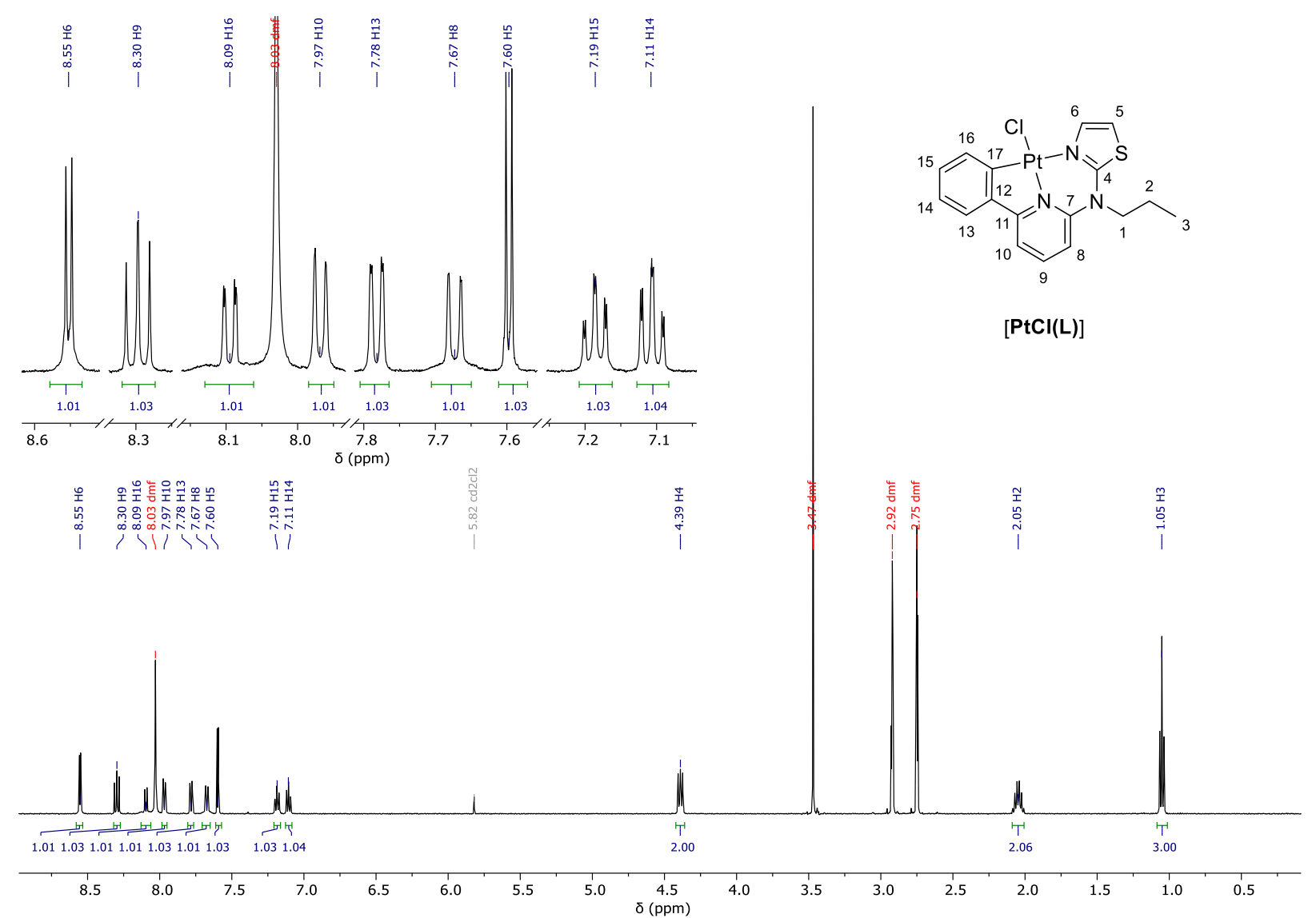

Figure S21. ${ }^{1} \mathrm{H}-\mathrm{NMR}$ spectrum (500 MHz, DMF-d7) of the complex [PtCl(L)].
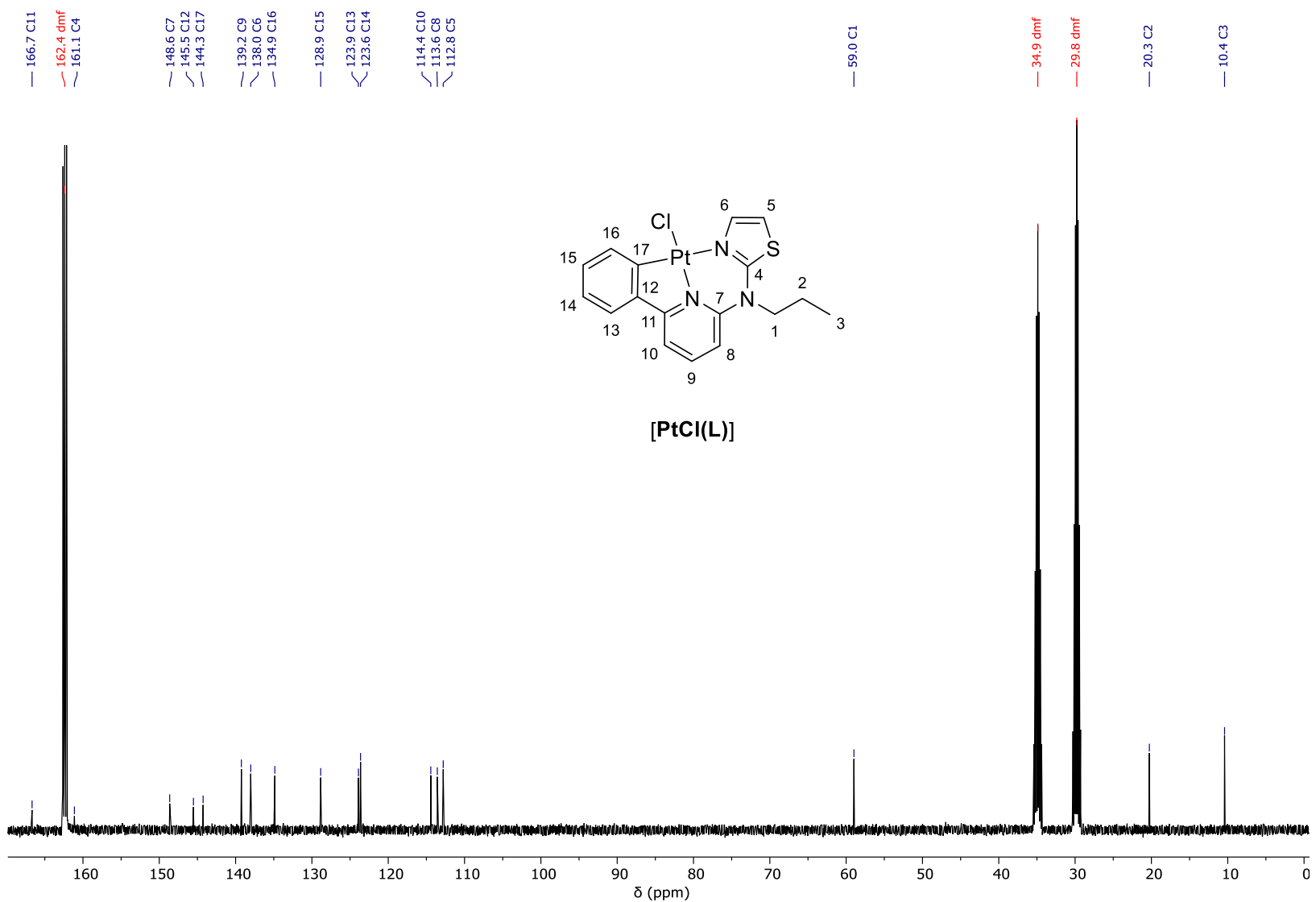

Figure S22. ${ }^{13} \mathrm{C}-\left\{{ }^{1} \mathrm{H}\right\}-\mathrm{NMR}$ spectrum (126 MHz, DMF-d $)$ of the complex $[\mathrm{PtCl}(\mathrm{L})]$. 


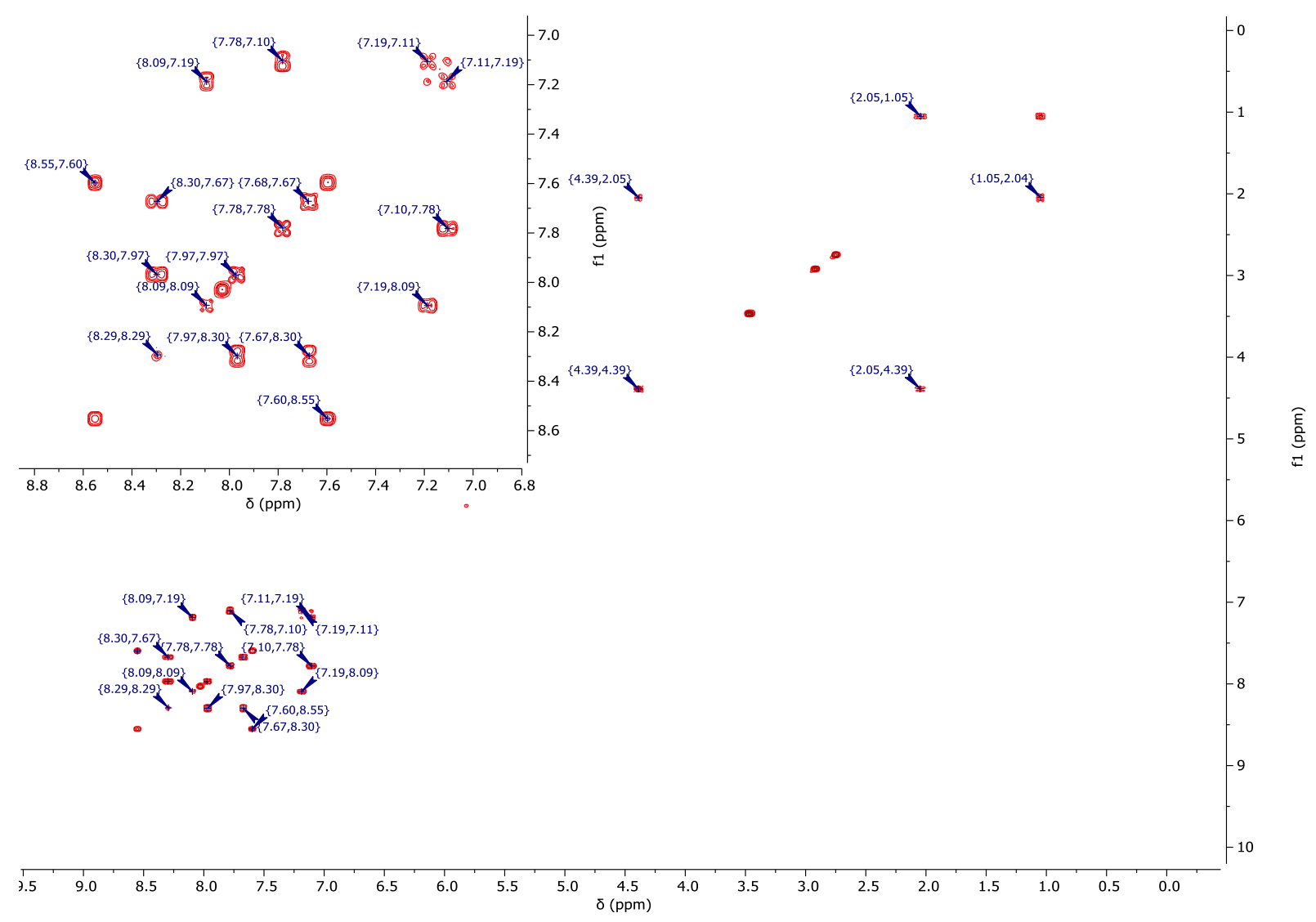

Figure S23. ${ }^{1} \mathrm{H} /{ }^{1} \mathrm{H}-\mathrm{COSY}-\mathrm{NMR}$ spectrum $\left(500 \mathrm{MHz} / 500 \mathrm{MHz}, \mathrm{DMF}-\mathrm{d}_{7}\right)$ of the complex $[\mathrm{PtCl}(\mathrm{L})]$.

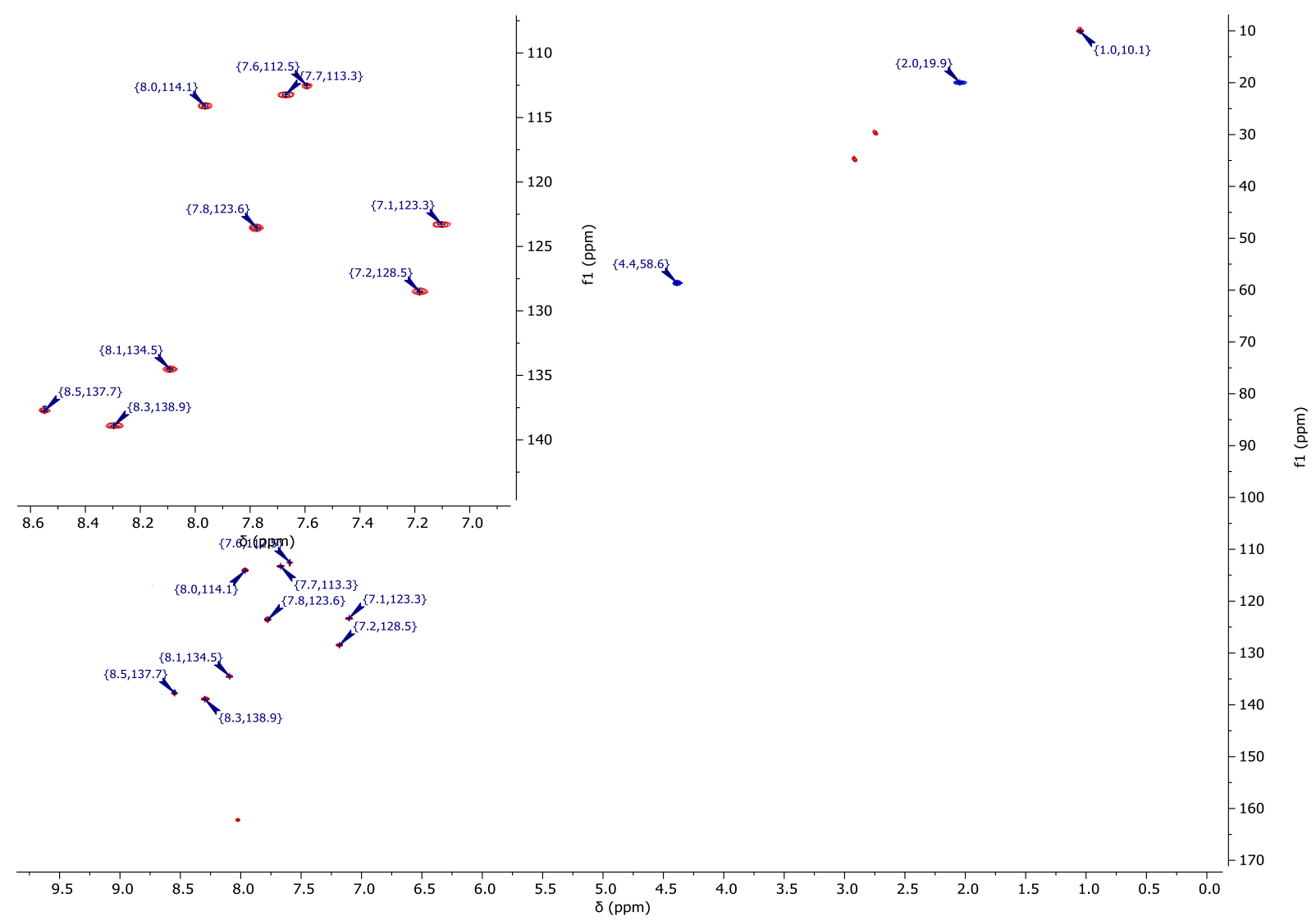

Figure S24. ${ }^{1} \mathrm{H} /{ }^{13} \mathrm{C}-\mathrm{gHSQC}-N M R$ spectrum $\left(500 \mathrm{MHz} / 126 \mathrm{MHz}, \mathrm{DMF}-\mathrm{d}_{7}\right)$ of the complex [PtCl(L)]. 


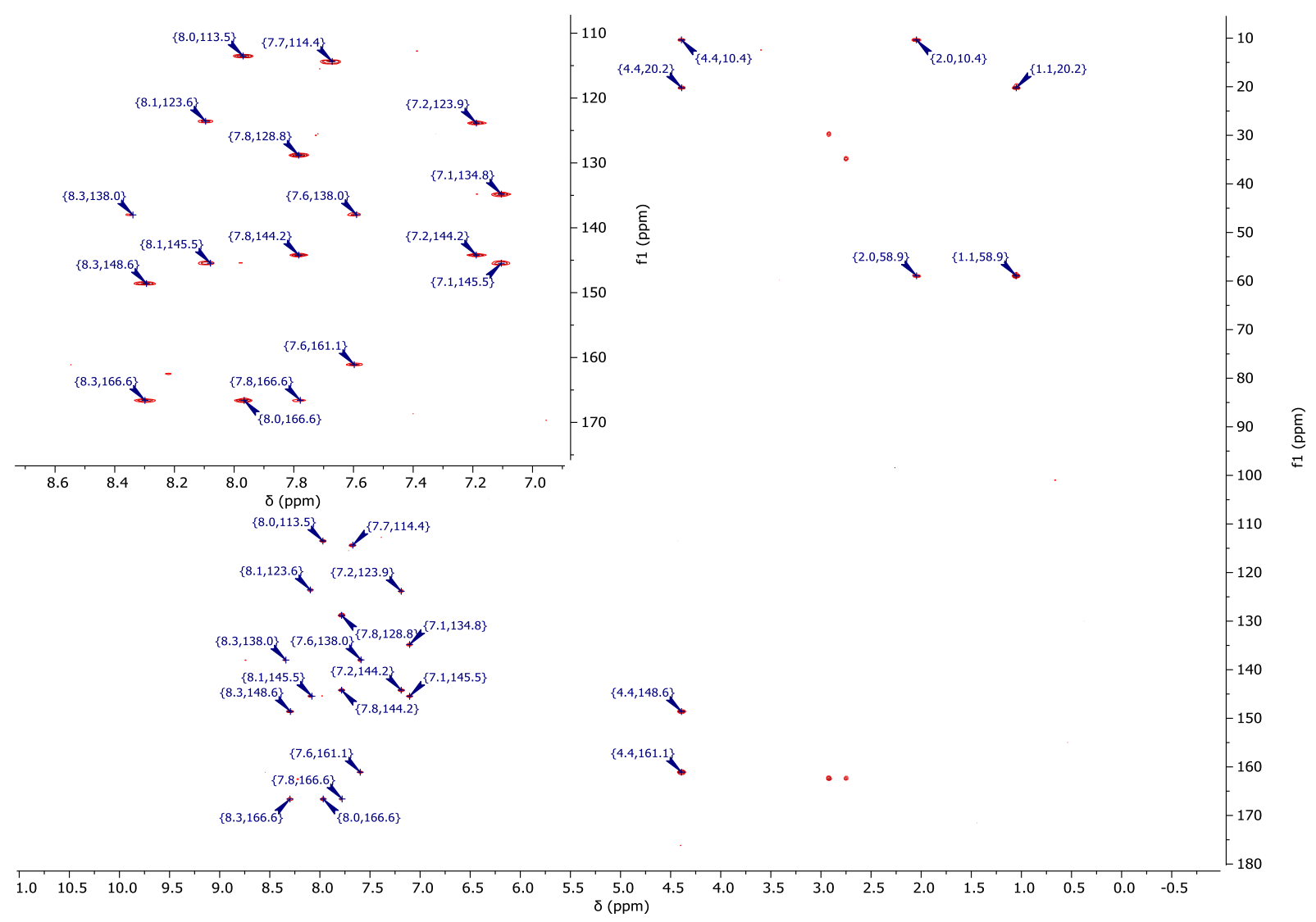

Figure S25. ${ }^{1} \mathrm{H} /{ }^{13} \mathrm{C}-\mathrm{gHMBC}-\mathrm{NMR}$ spectrum $\left(500 \mathrm{MHz} / 126 \mathrm{MHz}, \mathrm{DMF}-\mathrm{d}_{7}\right)$ of the complex $[\mathrm{PtCl}(\mathrm{L})]$.
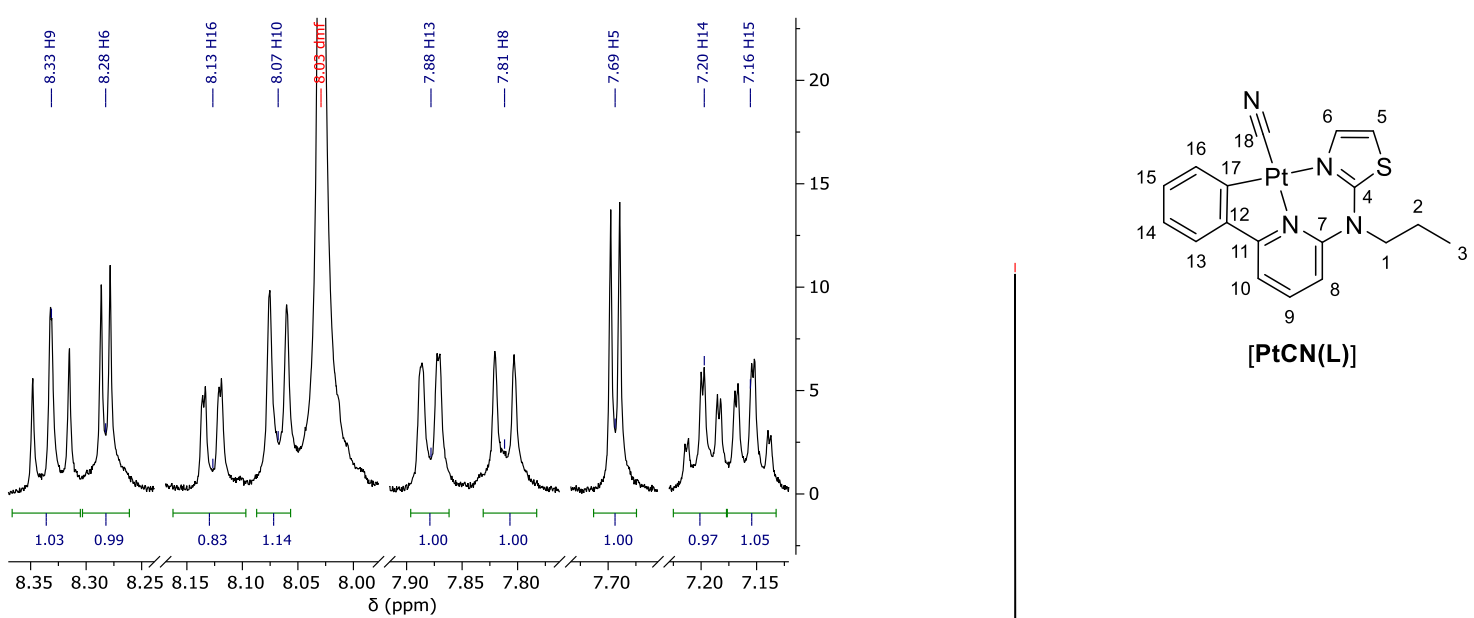

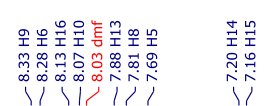

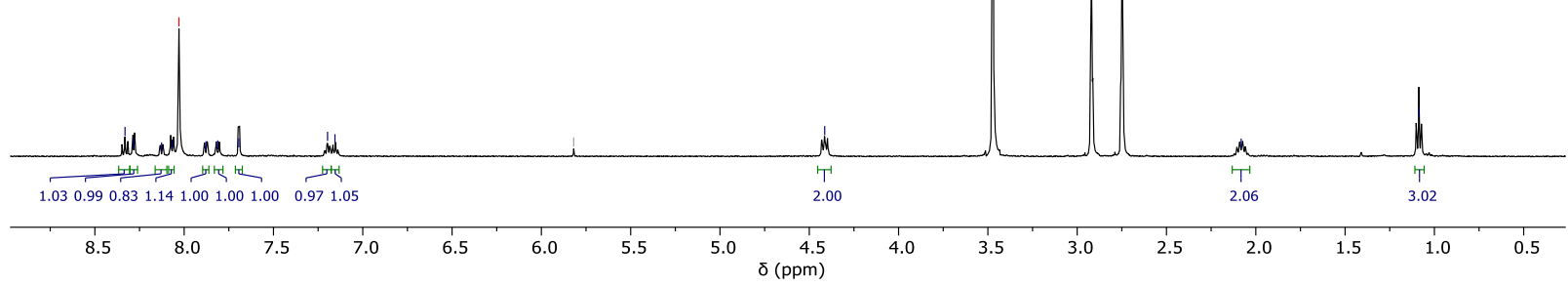

Figure S26. ${ }^{1} \mathrm{H}-\mathrm{NMR}$ spectrum $(500 \mathrm{MHz}, \mathrm{DMF}-\mathrm{d}$ 7) of the complex $[\mathrm{PtCN}(\mathrm{L})]$. 


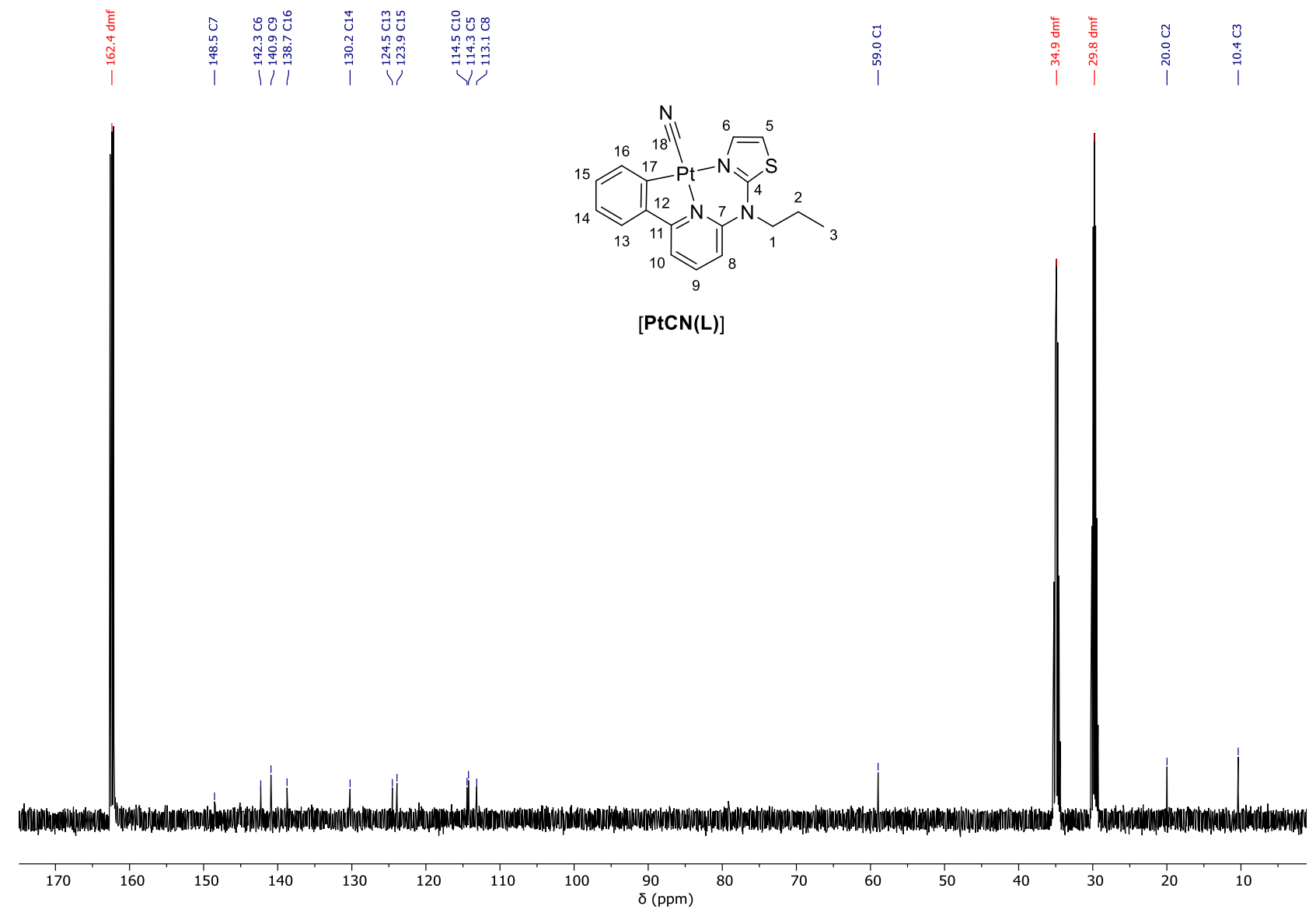

Figure S27. ${ }^{13} \mathrm{C}-\left\{{ }^{1} \mathrm{H}\right\}-N M R$ spectrum (126 MHz, DMF- $\left.\mathrm{d}_{7}\right)$ of the complex [PtCN(L)].

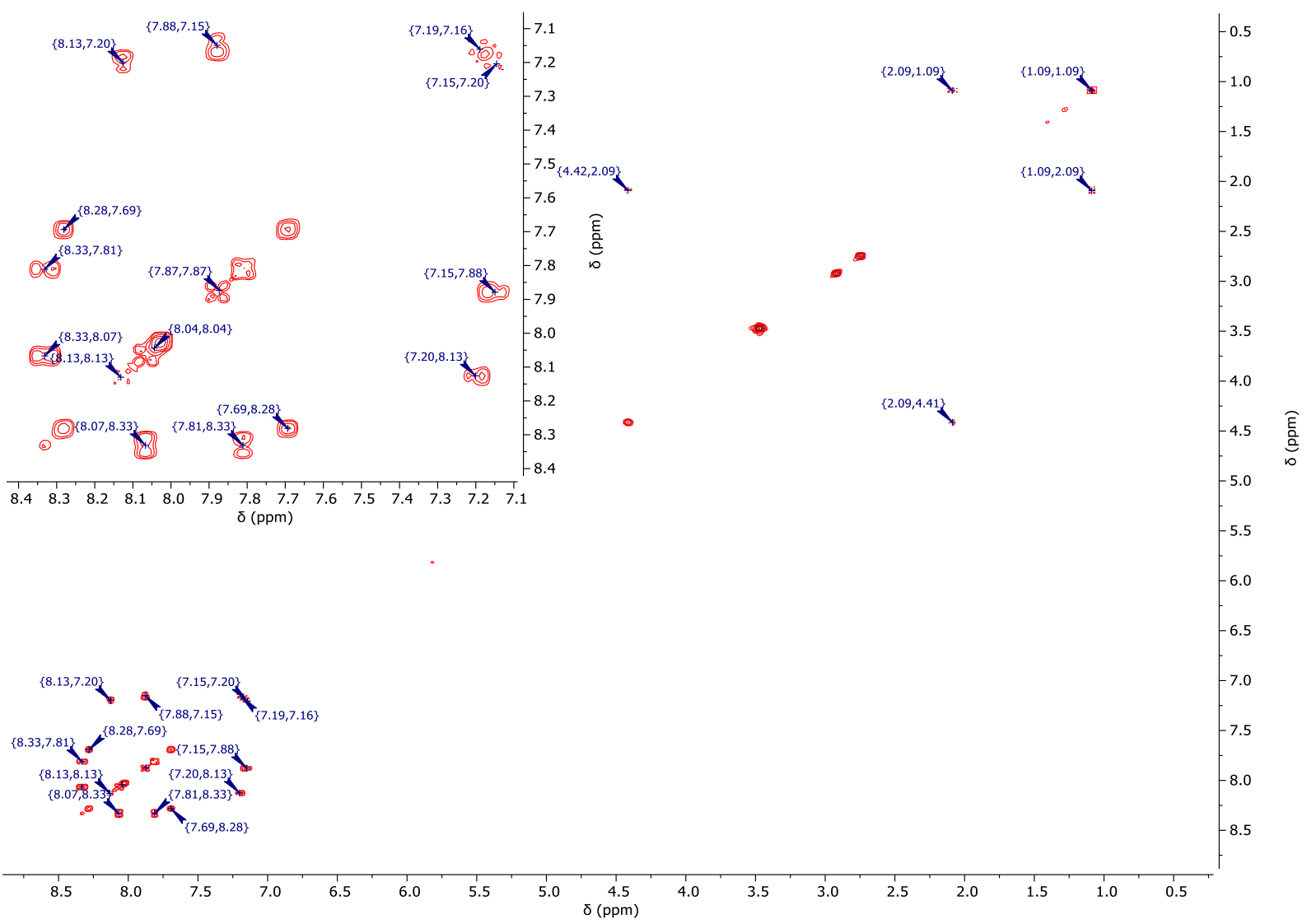

Figure S28. ${ }^{1} \mathrm{H} /{ }^{1} \mathrm{H}$-COSY-NMR spectrum $(500 \mathrm{MHz} / 500 \mathrm{MHz}, \mathrm{DMF}-\mathrm{d} 7)$ of the complex [PtCN(L)]. 


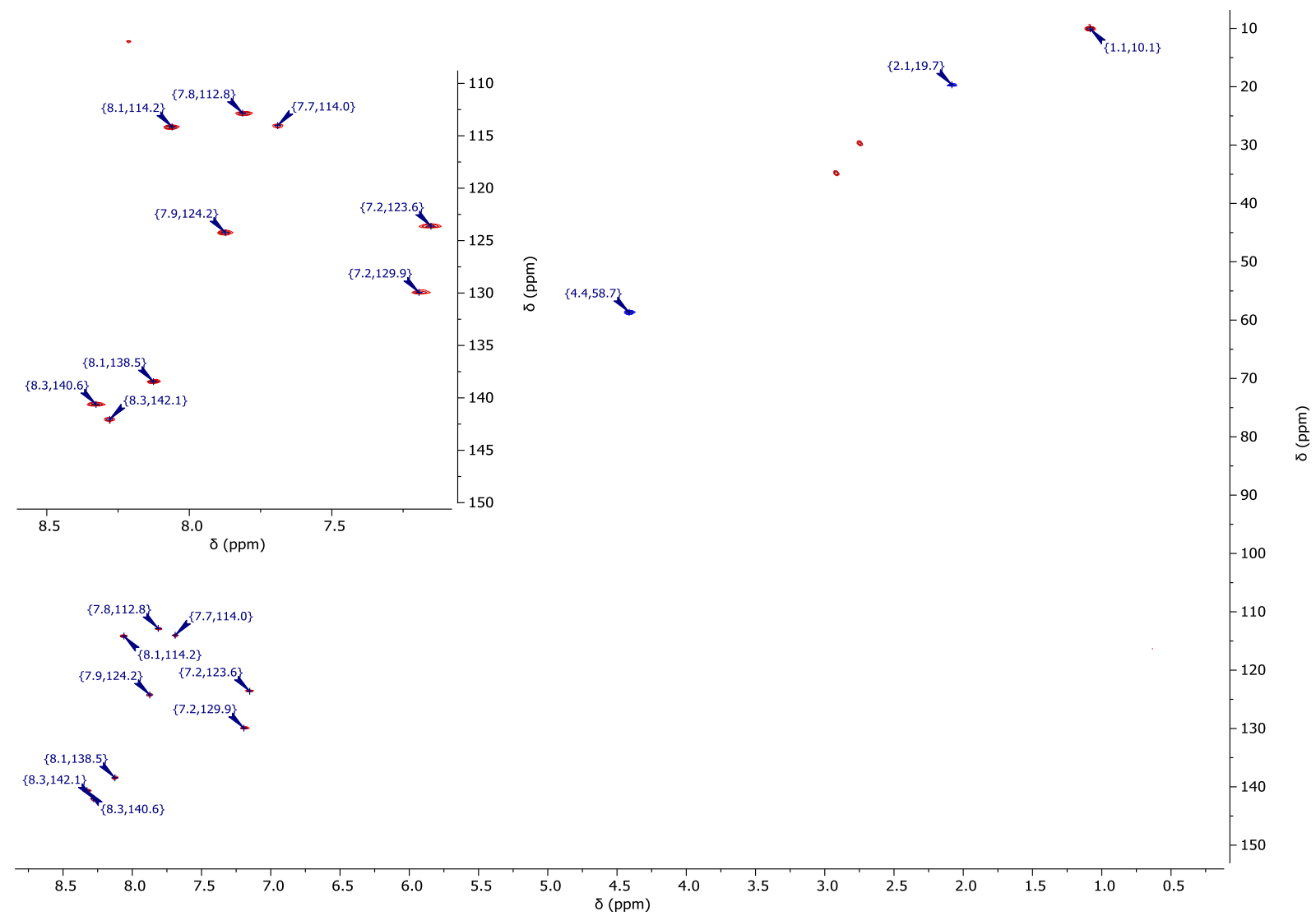

Figure S29. ${ }^{1} \mathrm{H} /{ }^{13} \mathrm{C}-\mathrm{gHSQC}-\mathrm{NMR}$ spectrum $\left(500 \mathrm{MHz} / 126 \mathrm{MHz}, \mathrm{DMF}-\mathrm{d}_{7}\right)$ of the complex [PtCN(L)].

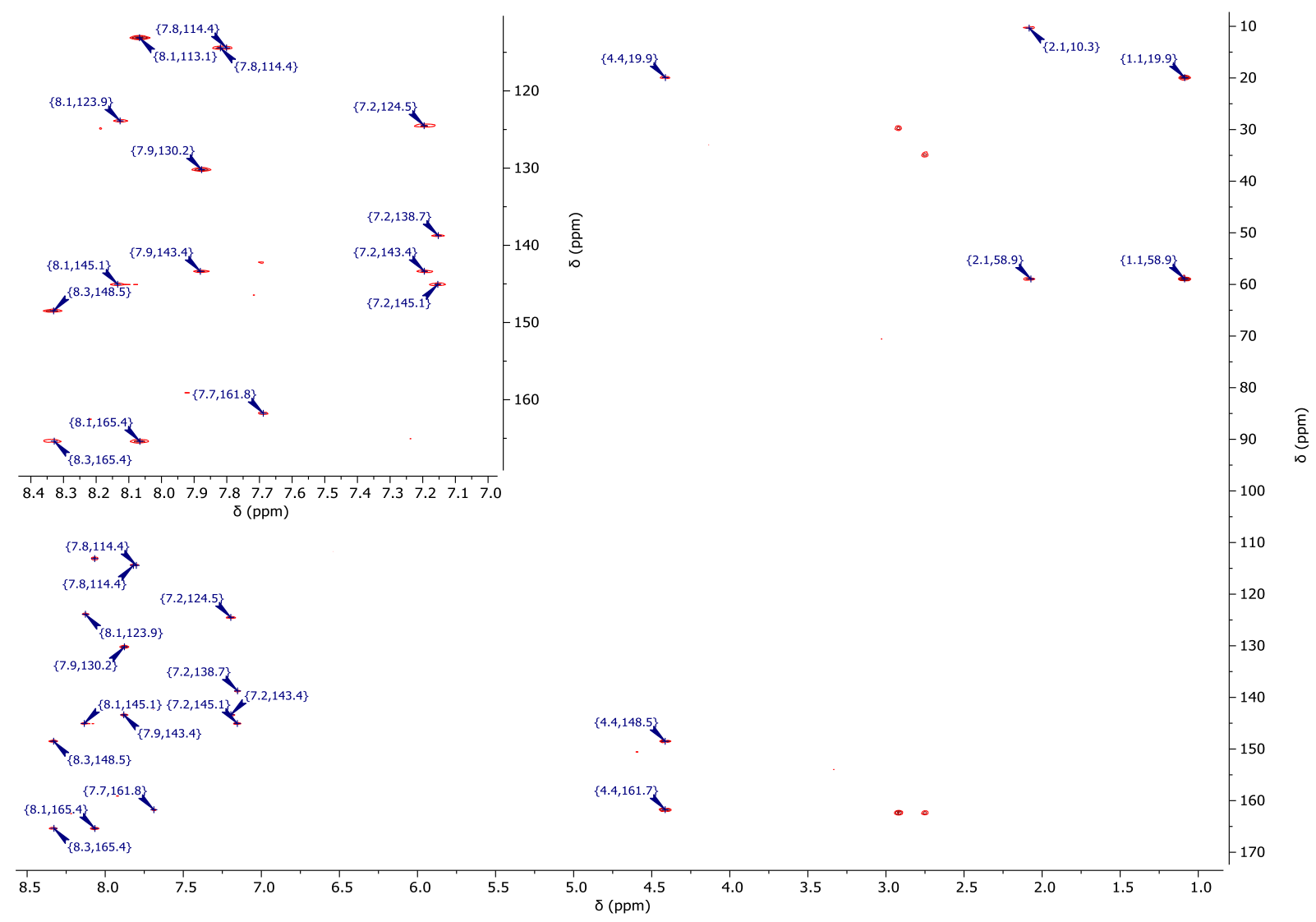

Figure S30. ${ }^{1} \mathrm{H} /{ }^{13} \mathrm{C}-\mathrm{gHMBC}-\mathrm{NMR}$ spectrum $\left(500 \mathrm{MHz} / 126 \mathrm{MHz}, \mathrm{DMF}-\mathrm{d}_{7}\right)$ of the complex $[\mathrm{PtCN}(\mathrm{L})]$. 


\section{Section S4: IR spectra of $[\mathrm{PtCl}(\mathrm{L})]$ and $[\mathrm{PtCN}(\mathrm{L})]$}

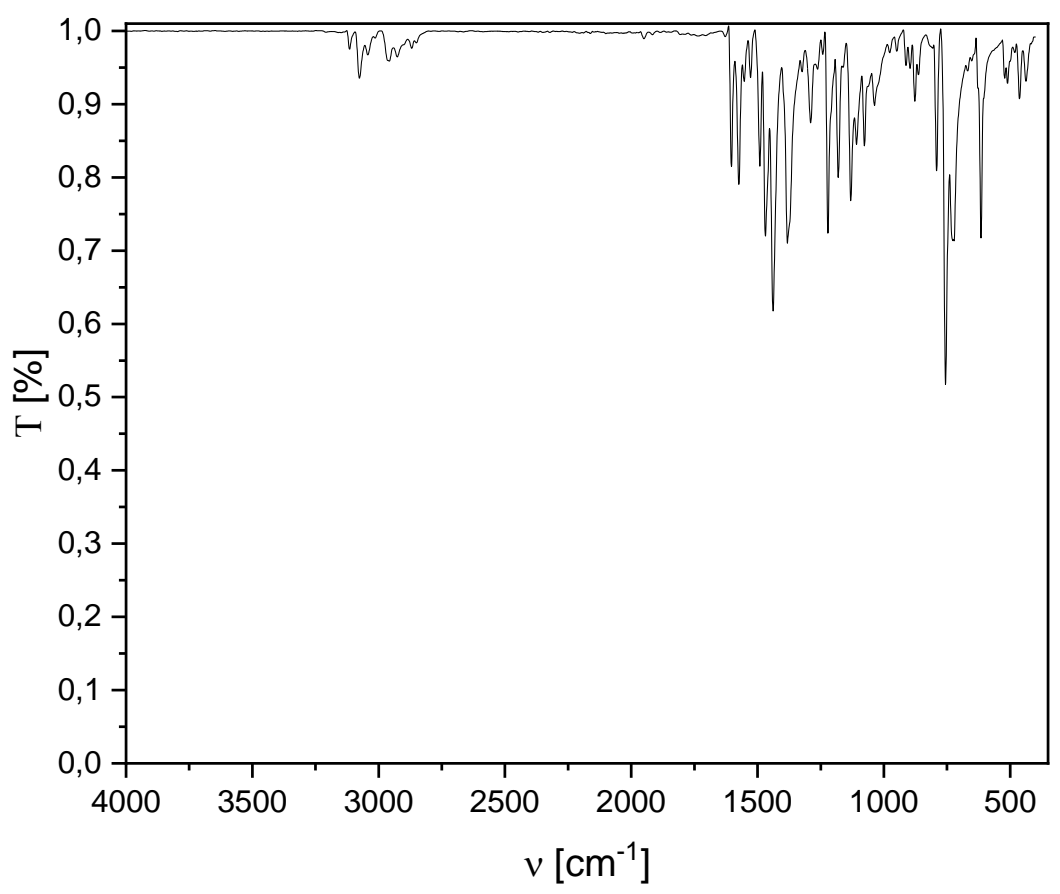

Figure S31. IR spectrum of [PtCl(L)].

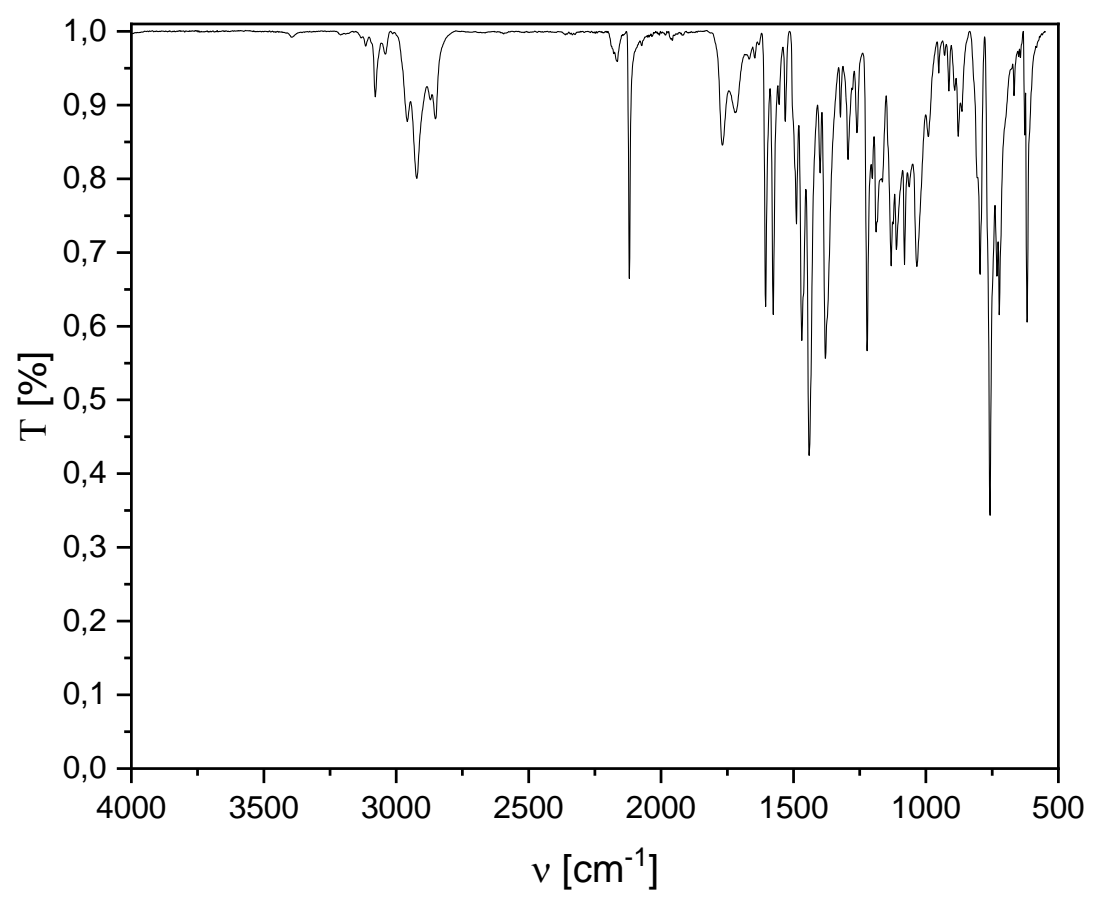

Figure S32. IR-spectrum of $[\mathrm{PtCN}(\mathrm{L})]$, the peak at $2120 \mathrm{~cm}^{-1}$ corresponds to the $\mathrm{CN}$-stretching. 


\section{Section S5: Single crystal X-ray diffraction analysis of 1, 2b, $[\mathrm{PtCl}(\mathrm{L})]$ and $[\operatorname{PtCN}(\mathrm{L})]$}

X-Ray diffraction: Data sets for compound [PtCN(L)] were collected with a Bruker D8 Venture CMOS diffractometer. For compounds $\mathbf{2 b}$ and $[\mathrm{PtCl}(\mathrm{L})]$, data sets were collected with a Bruker APEX II CCD diffractometer. Programs used: data collection: APEX3 V2016.1-03 (Bruker AXS Inc., 2016); cell refinement: SAINT V8.37A ${ }^{3}$ (Bruker AXS Inc., 2015); data reduction: SAINT V8.37A ${ }^{3}$ (Bruker AXS Inc., 2015); absorption correction, SADABS V2014/73 (Bruker AXS Inc., 2014); structure solution SHELXT$2015 ;{ }^{4}$ structure refinement SHELXL-2015. ${ }^{5}$ For compound 1 data sets were collected with a Nonius Kappa CCD diffractometer. Programs used: data collection, COLLECT (R. W. W. Hooft, Bruker AXS, 2008, Delft, The Netherlands); ${ }^{6}$ data reduction DenzoSMN;7 absorption correction, Denzo;8 structure solution SHELXT-2015; ${ }^{4}$ structure refinement SHELXL-20155 and graphics, $X P .{ }^{9} R$-values are given for observed reflections, and $w R^{2}$ values are given for all reflections.

Exceptions and special features: For compounds $[\mathrm{PtCl}(\mathrm{L})]$ and $[\mathrm{PtCN}(\mathrm{L})]$ the propyl group is disordered over two positions. Several restraints (SADI, SAME, ISOR and SIMU) were used in order to improve refinement stability. Additionally, for compound [PtCl(L)] a badly disordered half dichloromethane molecule and for compound [PtCN(L)] a disordered third cyclohexane molecule were found in the asymmetrical unit and could not be satisfactorily refined. The program SQUEEZE (Spek, A.L. (2015). Acta Cryst. C71, 9-18.) was therefore used to remove mathematically the effect of the solvent. The quoted formula and derived parameters are not included the squeezed solvent molecules.

CCDC-1978467 (1), CCDC-1978468 (2b), CCDC-1978469 ([PtCl(L)]) and CCDC1978470 ([PtCN(L)]) contain the supplementary crystallographic data for this paper. These data can be obtained free of charge from The Cambridge Crystallographic Data Centre via www.ccdc.cam.ac.uk/data_request/cif.

X-ray crystal structure analysis of 1 (dan8679): A colorless plate-like specimen of $\mathrm{C}_{8} \mathrm{H}_{6} \mathrm{BrN}_{3} \mathrm{~S}$, approximate dimensions $0.020 \mathrm{~mm} \times 0.200 \mathrm{~mm} \times 0.360 \mathrm{~mm}$, was used for the X-ray crystallographic analysis. The X-ray intensity data were measured. The integration of the data using a triclinic unit cell yielded a total of 3113 reflections to a maximum $\theta$ angle of $25.00^{\circ}(0.84 \AA$ resolution), of which 3113 were independent (average redundancy 1.000 , completeness $=95.6 \%, R_{\text {sig }}=3.06 \%$ ) and $2768(88.92 \%$ ) were greater than $2 \sigma\left(F^{2}\right)$. The final cell constants of $\underline{a}=7.8419(2) \AA, \underline{b}=9.9837(3) \AA$, $\underline{c}=12.3491(4) \AA, \alpha=94.368(2)^{\circ}, \beta=98.427(2)^{\circ}, y=103.6570(10)^{\circ}$, volume $=$ 923.16(5) $\AA^{3}$, are based upon the refinement of the XYZ-centroids of reflections above $20 \sigma(\mathrm{I})$. Data were corrected for absorption effects using the multi-scan method (SADABS). The calculated minimum and maximum transmission coefficients (based on crystal size) are 0.2860 and 0.9130 . The structure was solved and refined using the Bruker SHELXTL Software Package, using the space group $P-1$, with $Z=4$ for the formula unit, $\mathrm{C}_{8} \mathrm{H}_{6} \mathrm{BrN}_{3} \mathrm{~S}$. The final anisotropic full-matrix least-squares refinement on $\mathrm{F}^{2}$ with 243 variables converged at $\mathrm{R} 1=4.60 \%$, for the observed data and $\mathrm{wR} 2=$ $12.33 \%$ for all data. The goodness-of-fit was 1.105 . The largest peak in the final difference electron density synthesis was $0.585 \mathrm{e}^{-/ \AA^{3}}$ and the largest hole was -0.404 
$\mathrm{e}^{-} / \AA^{3}$ with an RMS deviation of $0.078 \mathrm{e}^{-} / \AA^{3}$. On the basis of the final model, the calculated density was $1.843 \mathrm{~g} / \mathrm{cm}^{3}$ and $\mathrm{F}(000), 504 \mathrm{e}$. The hydrogen atoms at $\mathrm{N} 6$ and N6A were refined freely, but with $\mathrm{N}-\mathrm{H}$ restrained distance for $\mathrm{N} 6$ atom (DFIX). CCDC number: 1978467.
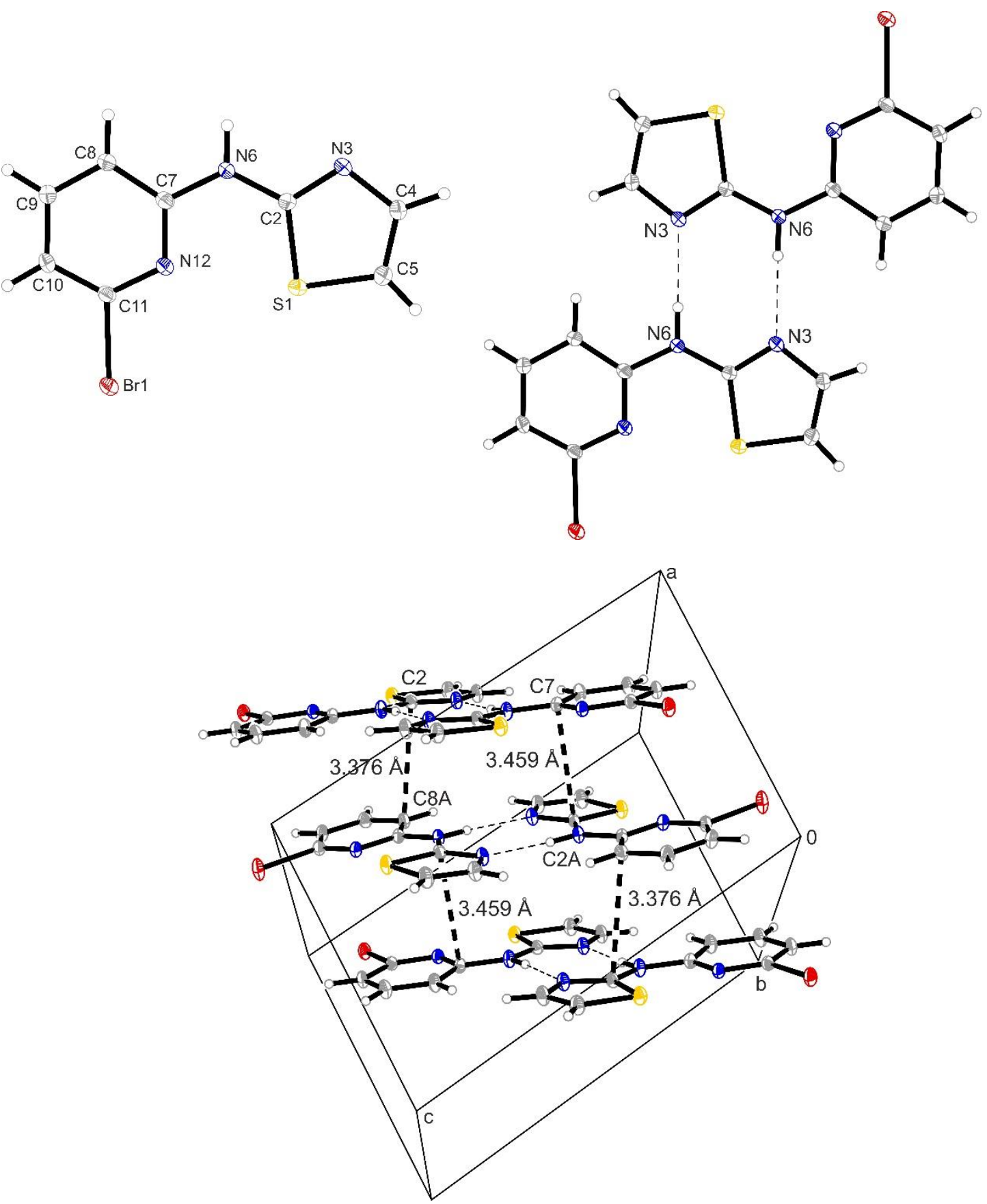

Figure S33. A) Molecular structure of $\mathbf{1}$ in the crystal. B) Dimer formation involving the $\mathrm{N}-\mathrm{H} \cdots \mathrm{N}$ hydrogen bonds interactions. C) Linear chain along the ab-diagonal involving $\pi^{\cdots} \pi$ interactions between dimeric units of $\mathbf{1}$ orientated $90^{\circ}$. Thermal ellipsoids are set at $15 \%$ probability. 
Table S1. Non-covalent intermolecular interactions in compound 1 ( $\AA$ and deg).

\begin{tabular}{lcccc}
\hline$D-\mathrm{H} \cdots A$ & $d(D-\mathrm{H})$ & $d(\mathrm{H} \cdots A)$ & $d(D \cdots A)$ & \multicolumn{1}{c}{$\angle(D \mathrm{H} A)$} \\
\hline $\mathrm{N} 6-\mathrm{H} 6 \cdots \mathrm{N}^{\# 1}$ & $0.89(2)$ & $2.05(2)$ & $2.942(6)$ & $176(6)$ \\
$\mathrm{N} 6 \mathrm{~A}-\mathrm{H} 6 \mathrm{~A} \cdots \mathrm{N} 3 \mathrm{~A}^{\# 2}$ & $0.90(6)$ & $2.05(6)$ & $2.948(6)$ & $176(5)$ \\
$\mathrm{C} 2 \cdots \mathrm{C} 8 \mathrm{~A}^{\# 3}$ & & & 3.376 & \\
$\mathrm{C} 7 \cdots \mathrm{C}^{\#} \mathrm{~A}^{\# 3}$ & & & 3.459 &
\end{tabular}

Symmetry transformations used to generate equivalent atoms: ${ }^{\# 1}-\mathrm{x}-1,-\mathrm{y}+1,-\mathrm{z} ;{ }^{\# 2}-\mathrm{x}-2$, $-y+1,-z ;{ }^{3}-x-2,-y+1,-z$.

X-ray crystal structure analysis of $\mathbf{2 b}$ (dan9627): A colorless prism-like specimen of $\mathrm{C}_{11} \mathrm{H}_{12} \mathrm{BrN}_{3} \mathrm{~S}$, approximate dimensions $0.040 \mathrm{~mm} \times 0.080 \mathrm{~mm} \times 0.160 \mathrm{~mm}$, was used for the X-ray crystallographic analysis. The X-ray intensity data were measured. A total of 1569 frames were collected. The total exposure time was 16.45 hours. The frames were integrated with the Bruker SAINT software package using a wide-frame algorithm. The integration of the data using an orthorhombic unit cell yielded a total of 17703 reflections to a maximum $\theta$ angle of $66.76^{\circ}(0.84 \AA$ resolution), of which 2109 were independent (average redundancy 8.394, completeness $=99.9 \%$, Rint $=3.52 \%$, $\left.R_{\text {sig }}=1.93 \%\right)$ and $1935(91.75 \%)$ were greater than $2 \sigma\left(F^{2}\right)$. The final cell constants of $\underline{\mathrm{a}}=13.3701(3) \AA, \underline{\mathrm{b}}=8.1413(2) \AA, \underline{c}=21.9260(5) \AA$, volume $=2386.64(10) \AA^{3}$, are based upon the refinement of the XYZ-centroids of 7270 reflections above $20 \sigma(\mathrm{I})$ with $10.43^{\circ}<2 \theta<133.3^{\circ}$. Data were corrected for absorption effects using the multi-scan method (SADABS). The ratio of minimum to maximum apparent transmission was 0.841 . The calculated minimum and maximum transmission coefficients (based on crystal size) are 0.4400 and 0.7920 . The structure was solved and refined using the Bruker SHELXTL Software Package, using the space group Pbca, with $Z=8$ for the formula unit, $\mathrm{C}_{11} \mathrm{H}_{12} \mathrm{BrN} \mathrm{N}_{3} \mathrm{~S}$. The final anisotropic full-matrix least-squares refinement on $\mathrm{F}^{2}$ with 146 variables converged at $\mathrm{R} 1=2.25 \%$, for the observed data and $\mathrm{wR} 2=$ $5.85 \%$ for all data. The goodness-of-fit was 1.070 . The largest peak in the final difference electron density synthesis was $0.290 \mathrm{e}^{-/} \AA^{3}$ and the largest hole was -0.536 $\mathrm{e}^{-} / \AA^{3}$ with an RMS deviation of $0.064 \mathrm{e}^{\mathrm{e} / \AA^{3}}$. On the basis of the final model, the calculated density was $1.660 \mathrm{~g} / \mathrm{cm}^{3}$ and F(000), $1200 \mathrm{e}$. CCDC number: 1978468. 

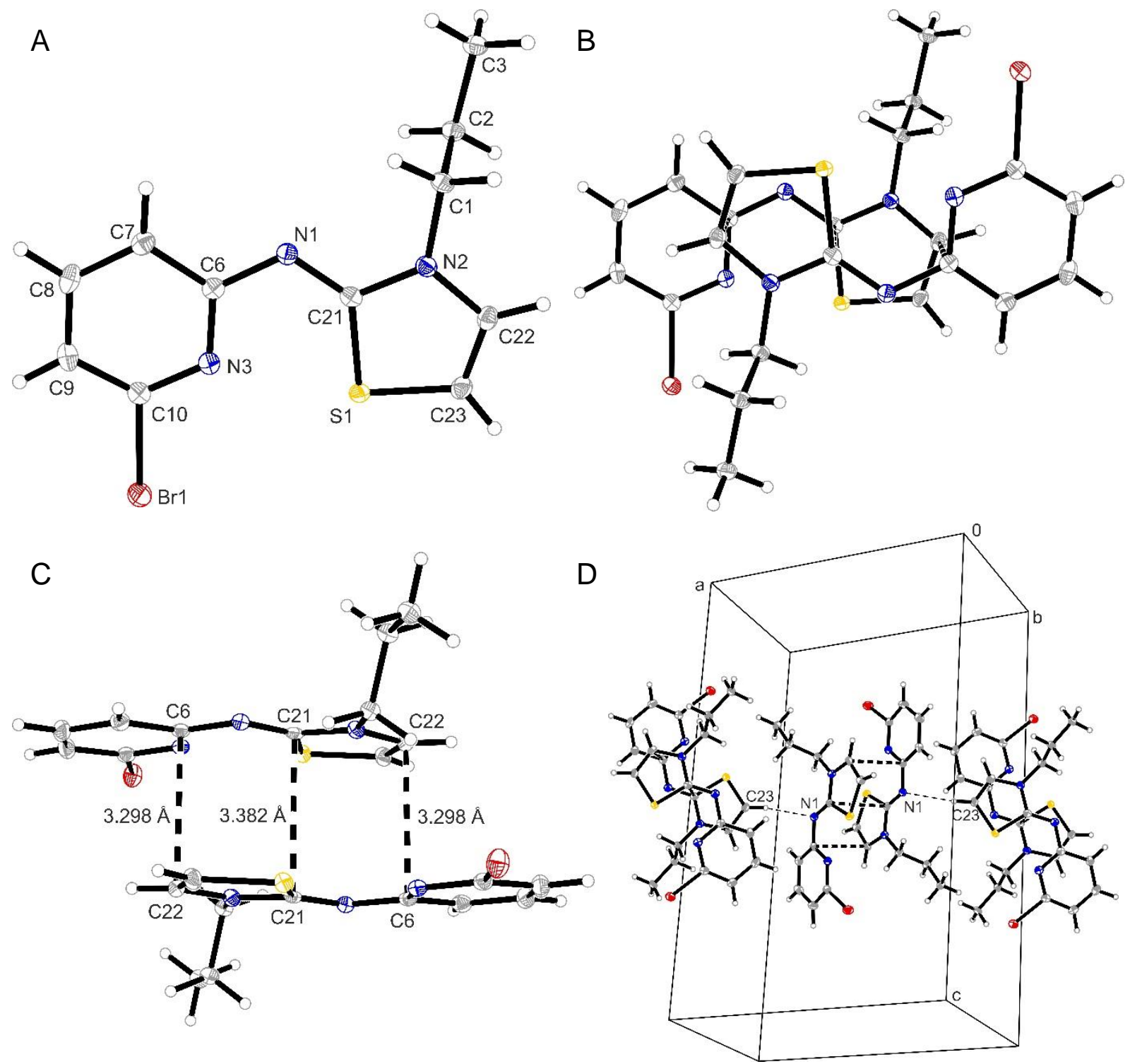

Figure S34. A) Molecular structure of $\mathbf{2} \mathbf{b}$ in the crystal. B) Dimer formation involving $\pi^{\cdots} \pi$ interactions: side view and perpendicular view. C/D) Excerpt of the $2 \mathrm{D}$ network involving the $\mathrm{C}-\mathrm{H} \cdots \mathrm{N}$ hydrogen bonds interactions between dimeric units of $\mathbf{2 b}$ (angle between these dimeric units is $54^{\circ}$ ). Thermal ellipsoids are set at $50 \%$ probability.

Table S2. Non-covalent intermolecular interactions in compound $\mathbf{2 b}(\AA$ and deg).

\begin{tabular}{lcccc}
\hline$D-\mathrm{H} \cdots A$ & $d(D-\mathrm{H})$ & $d(\mathrm{H} \cdots A)$ & $d(D \cdots A)$ & \multicolumn{1}{c}{$\angle(D \mathrm{H} A)$} \\
\hline $\mathrm{C} 23-\mathrm{H} 23 \cdots \mathrm{N} 1{ }^{\# 1}$ & 0.95 & $2.66(2)$ & $3.531(3)$ & $152.2(3)$ \\
$\mathrm{C} 21 \cdots \mathrm{C} 21^{\# 2}$ & & 3.382 & \\
$\mathrm{C} 6 \cdots \mathrm{C} 22^{\# 2}$ & & 3.298
\end{tabular}

Symmetry transformations used to generate equivalent atoms: ${ }^{\# 1} \mathrm{x}-0.5,-\mathrm{y}+1.5,-\mathrm{z}+1$; $\# 2-x+1,-y+1,-z+1$. 
X-ray crystal structure analysis of [ $\mathrm{PtCl}(\mathrm{L})]$ (dan9312): A yellow plate-like specimen of $\mathrm{C}_{17} \mathrm{H}_{16} \mathrm{CIN}_{3} \mathrm{PtS}$, approximate dimensions $0.040 \mathrm{~mm} \times 0.070 \mathrm{~mm} \times 0.120 \mathrm{~mm}$, was used for the X-ray crystallographic analysis. The X-ray intensity data were measured. A total of 1621 frames were collected. The total exposure time was 15.30 hours. The frames were integrated with the Bruker SAINT software package using a wide-frame algorithm. The integration of the data using a trigonal unit cell yielded a total of 32146 reflections to a maximum $\theta$ angle of $66.78^{\circ}$ ( $0.84 \AA$ resolution), of which 3052 were independent (average redundancy 10.533 , completeness $=99.4 \%$, Rint $=7.49 \%$, Rsig $=3.20 \%)$ and $2673(87.58 \%)$ were greater than $2 \sigma\left(\mathrm{F}^{2}\right)$. The final cell constants of $\underline{a}=$ 32.5075(9) $\AA, \underline{b}=32.5075(9) \AA, \underline{c}=8.5066(2) \AA$, volume $=7784.9(5) \AA^{3}$, are based upon the refinement of the XYZ-centroids of 8984 reflections above $20 \sigma(\mathrm{I})$ with $10.88^{\circ}$ $<2 \theta<133.3^{\circ}$. Data were corrected for absorption effects using the multi-scan method (SADABS). The ratio of minimum to maximum apparent transmission was 0.613 . The calculated minimum and maximum transmission coefficients (based on crystal size) are 0.2250 and 0.5370 . The final anisotropic full-matrix least-squares refinement on $\mathrm{F}^{2}$ with 238 variables converged at $R 1=2.31 \%$, for the observed data and $w R 2=5.45 \%$ for all data. The goodness-of-fit was 0.976 . The largest peak in the final difference electron density synthesis was $0.627 \mathrm{e}^{-} / \AA^{3}$ and the largest hole was $-0.703 \mathrm{e}^{-} / \AA^{3}$ with an RMS deviation of $0.106 \mathrm{e}^{-/} / \AA^{3}$. On the basis of the final model, the calculated density was $2.015 \mathrm{~g} / \mathrm{cm}^{3}$ and $\mathrm{F}(000)$, $4500 \mathrm{e}$. CCDC number: 1978469. 

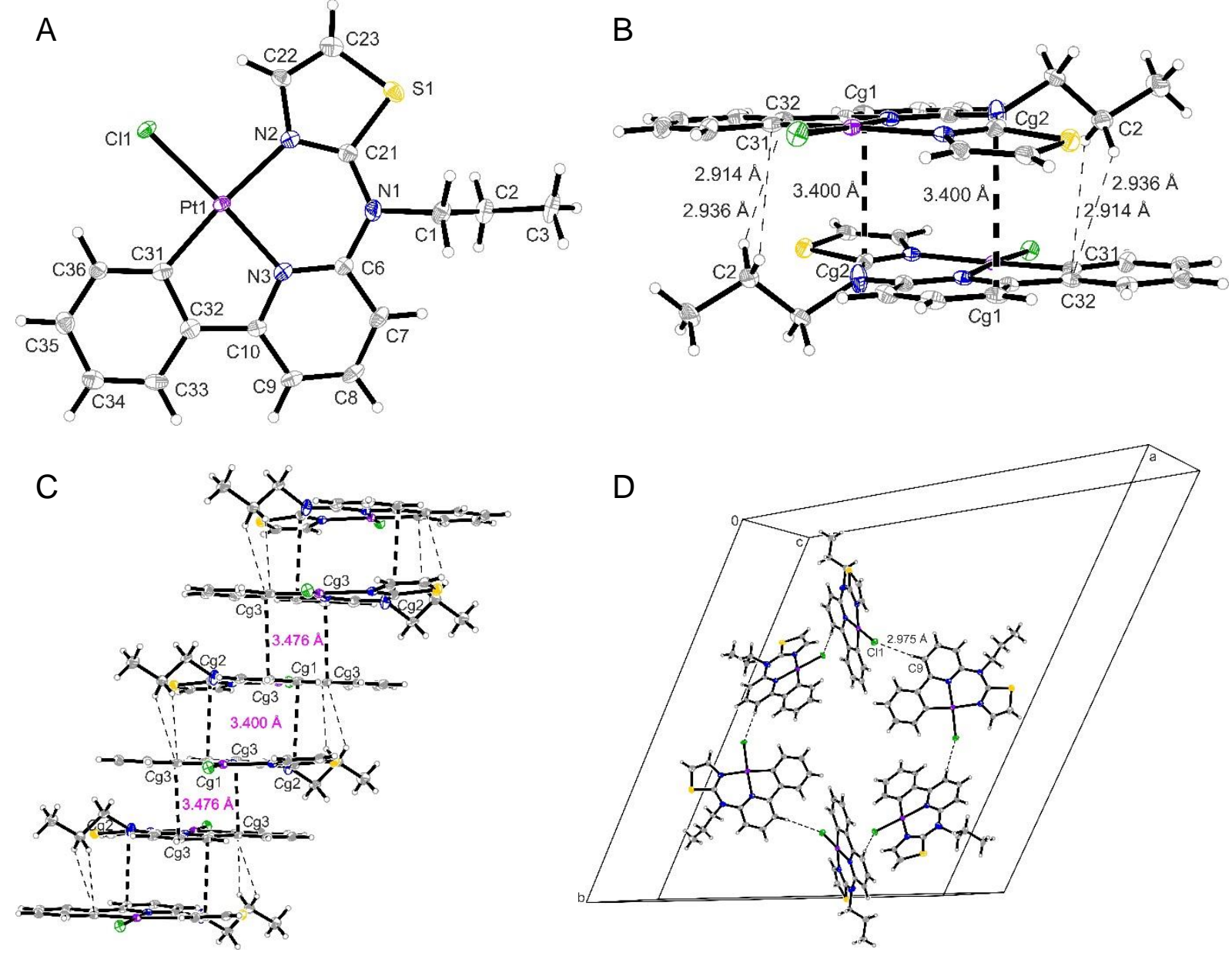

Figure S35. A) Molecular structure of $[\mathrm{PtCl}(\mathrm{L})]$ in the crystal. B) Dimer type formation involving $\pi \cdots \pi$ and $\mathrm{C}-\mathrm{H} \cdots \pi$ interactions. C) Linear chain formation trough $\pi^{\cdots} \pi$ interactions between dimeric units. D) Excerpt of the packing diagram of $[\mathrm{PtCl}(\mathrm{L})]$ presenting the hexagonal arrangement of molecules trough $\mathrm{C}-\mathrm{H} \cdots \mathrm{Cl}$ interactions. The angle between the complex molecules (linear chains, respectively) is $63^{\circ}$. Thermal ellipsoids are set at $30 \%$ probability. 
Table S3. Non-covalent intermolecular interactions in compound $[\mathrm{PtCl}(\mathrm{L})](\AA$ and deg).

\begin{tabular}{lcccc}
\hline$D-H \cdots A$ & $d(D-H)$ & $d(H \cdots A)$ & $d(D \cdots A)$ & \multicolumn{2}{c}{$\angle(D \mathrm{H} A)$} \\
\hline $\mathrm{C} 2-\mathrm{H} 2 \mathrm{H} \cdots \mathrm{C} 32^{\# 1}$ & 0.98 & $2.94(4)$ & $3.607(4)$ & $125.9(4)$ \\
$\mathrm{C} 2-\mathrm{H} 2 \mathrm{~B} \cdots \mathrm{C} 31^{\# 1}$ & 0.98 & $2.91(5)$ & $3.497(4)$ & $118.6(4)$ \\
$\mathrm{Cg} 1 \cdots \mathrm{Cg} 2^{\# 1}$ & & & 3.400 & \\
$\mathrm{Cg} 3 \cdots \mathrm{Cg} 3^{\# 2}$ & & & 3.476 & \\
$\mathrm{Cg} 4 \cdots \mathrm{S} 1 \# 3$ & & & 3.358 & \\
$\mathrm{C} 8-\mathrm{H} 8 \cdots \mathrm{S} 1 \# 4$ & 0.95 & $2.88(4)$ & $3.804(4)$ & $162.8(3)$ \\
$\mathrm{C} 23-\mathrm{H} 23 \cdots \mathrm{Pt1}{ }^{\# 3}$ & 0.95 & $2.94(4)$ & $3.753(4)$ & $143.5(3)$ \\
$\mathrm{C} 9-\mathrm{H} 9 \cdots \mathrm{Cl} 1^{\# 5}$ & 0.95 & $2.97(4)$ & $3.919(4)$ & $173.1(3)$ \\
$\mathrm{Pt1} \cdots \mathrm{Pt2}{ }^{\# 1}$ & & & 5.905 & \\
\hline
\end{tabular}

Symmetry transformations used to generate equivalent atoms: \#1 $-x+1,-y+1,-z+1 ; \# 2-$ $x+1,-y+1,-z+2 ;{ }^{3}-y+0.66,+x-y+0.33, z-0.66 ;{ }^{* 4} y-0.33,-x+y+0.33,-z+1.33 ; \# 5 y+0.33$, $-\mathrm{x}+\mathrm{y}+0.66,-\mathrm{z}+1.66 . \mathrm{Cg} 1$ is the centroid involving the atoms C8 and C9; Cg2 is the centroid involving the atoms $\mathrm{C} 21 / \mathrm{N} 2 / \mathrm{C} 22 / \mathrm{C} 23 / \mathrm{S} 1 ; \mathrm{Cg} 3$ is the centroid involving the atoms $\mathrm{C} 7 / \mathrm{C} 8 / \mathrm{C} 9 / \mathrm{C} 10 / \mathrm{C} 32 / \mathrm{C} 33 ; \mathrm{Cg} 4$ is the centroid involving the atoms $\mathrm{C} 31$ and C36.

X-ray crystal structure analysis of [PtCN(L)] (dan9661): A pale yellow needle-like specimen of $\mathrm{C}_{18} \mathrm{H}_{16} \mathrm{~N}_{4} \mathrm{PtS}$, approximate dimensions $0.043 \mathrm{~mm} \times 0.048 \mathrm{~mm} \times 0.131$ $\mathrm{mm}$, was used for the $X$-ray crystallographic analysis. The X-ray intensity data were measured. A total of 1490 frames were collected. The total exposure time was 22.13 hours. The frames were integrated with the Bruker SAINT software package using a wide-frame algorithm. The integration of the data using a trigonal unit cell yielded a total of 32565 reflections to a maximum $\theta$ angle of $68.58^{\circ}(0.83 \AA$ resolution), of which 3236 were independent (average redundancy 10.063 , completeness $=100.0 \%$, Rint $=$ $7.64 \%$, Rsig $=3.35 \%)$ and $2844(87.89 \%)$ were greater than $2 \sigma\left(F^{2}\right)$. The final cell constants of $\underline{a}=32.7023(5) \AA, \underline{b}=32.7023(5) \AA, \underline{c}=8.5173(2) \AA$, volume $=7888.4(3)$ $\AA^{3}$, are based upon the refinement of the XYZ-centroids of 9962 reflections above 20 $\sigma(\mathrm{I})$ with $5.404^{\circ}<2 \theta<137.1^{\circ}$. Data were corrected for absorption effects using the multi-scan method (SADABS). The ratio of minimum to maximum apparent transmission was 0.749. The calculated minimum and maximum transmission coefficients (based on crystal size) are 0.2260 and 0.5440 . The structure was solved and refined using the Bruker SHELXTL Software Package, using the space group $R$ 3 , with $Z=18$ for the formula unit, $\mathrm{C}_{18} \mathrm{H}_{16} \mathrm{~N}_{4} \mathrm{PtS}$. The final anisotropic full-matrix leastsquares refinement on $\mathrm{F}^{2}$ with 245 variables converged at $\mathrm{R} 1=3.24 \%$, for the observed data and $\mathrm{wR} 2=6.95 \%$ for all data. The goodness-of-fit was 1.107 . The largest peak in the final difference electron density synthesis was $0.993 \mathrm{e}^{\mathrm{e} / \AA^{3}}$ and the largest hole was $-0.674 \mathrm{e}^{-} / \AA^{3}$ with an RMS deviation of $0.132 \mathrm{e}^{-} / \AA^{3}$. On the basis of the final model, the calculated density was $1.953 \mathrm{~g} / \mathrm{cm}^{3}$ and $F(000), 4428 \mathrm{e}^{-}$. CCDC number: 1978470. 

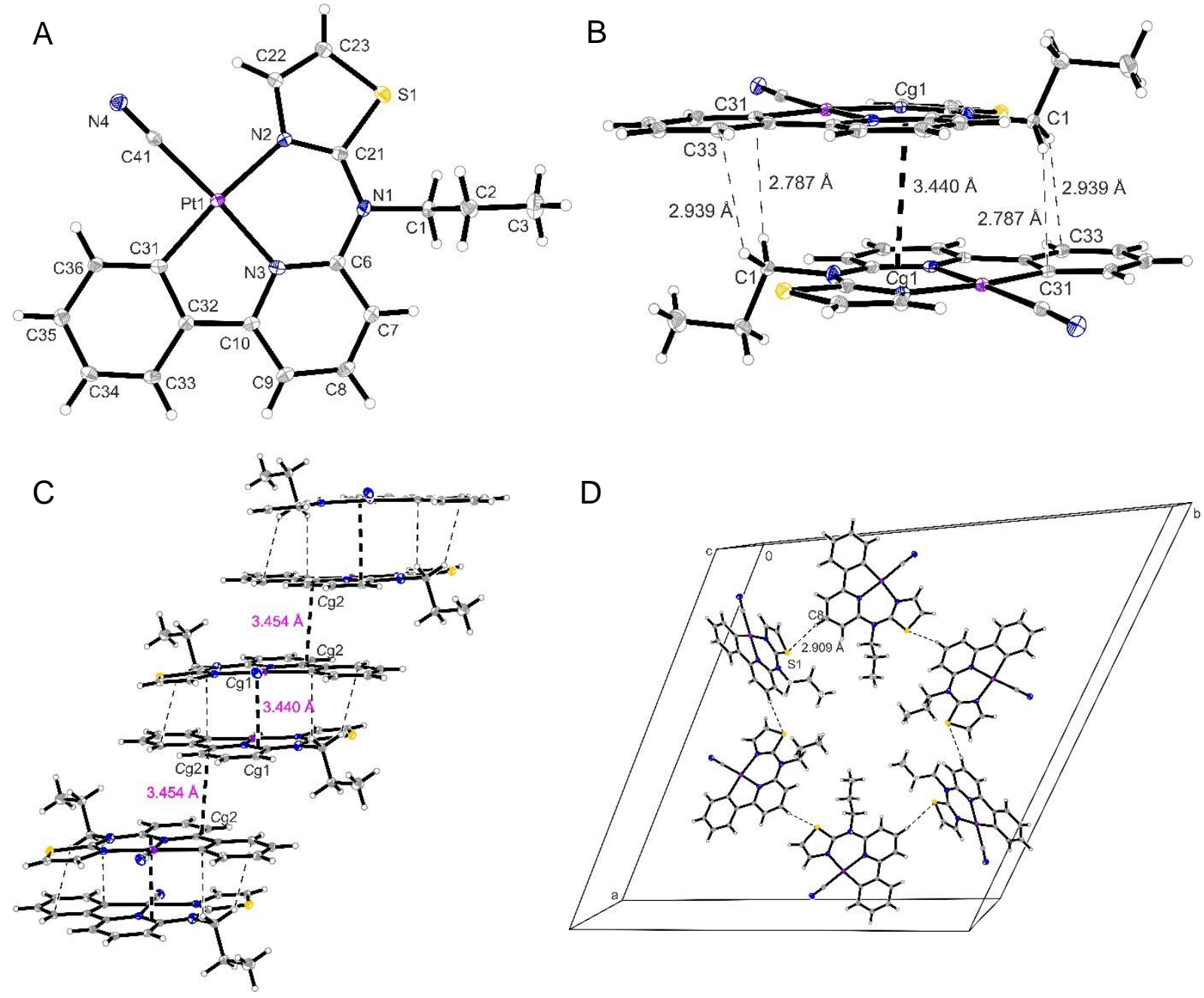

Figure S36. A) Molecular structure of $[\mathrm{PtCN}(\mathrm{L})]$ in the crystal. B) Dimer type formation involving $\pi \cdots \pi$ and $\mathrm{C}-\mathrm{H} \cdots \pi$ interactions. C) Linear chain formation trough $\pi \cdots \pi$ interactions between dimeric units. D) Excerpt of the packing diagram of $[\mathrm{PtCN}(\mathrm{L})]$ compound presenting the hexagonal arrangement of molecules trough $\mathrm{C}-\mathrm{H} \cdots \mathrm{S}$ interactions. The angle between the complex molecules (linear chains, respectively) is $65^{\circ}$. Thermal ellipsoids are set at $15 \%$ probability. 
Table S4. Non-covalent intermolecular interactions in compound $[\mathrm{PtCN}(\mathrm{L})](\AA \AA$ and deg).

\begin{tabular}{|c|c|c|c|c|}
\hline$D-\mathrm{H}^{\prime} \cdots A$ & $d(D-\mathrm{H})$ & $d(\mathrm{H} \cdots A)$ & $d(D \cdots A)$ & \\
\hline $\mathrm{C} 1-\mathrm{H} 1 \mathrm{~A}^{\cdots} \mathrm{C} \mathrm{C} 3^{\# 1}$ & 0.98 & $2.94(3)$ & $3.717(3)$ & $136.2(3)$ \\
\hline $\mathrm{C} 1-\mathrm{H} 1 \mathrm{~B} \cdots \mathrm{C} 31^{\# 1}$ & 0.98 & $2.79(3)$ & $3.425(3)$ & $122.7(3)$ \\
\hline$C g 1 \cdots \operatorname{Cg} 1^{\# 1}$ & & & 3.440 & \\
\hline $\operatorname{Cg} 2 \cdots \operatorname{Cg} 2^{\# 2}$ & & & 3.454 & \\
\hline $\mathrm{C} 36 \cdots \mathrm{S} 1^{\# 3}$ & & & 3.307 & \\
\hline $\mathrm{C} 8-\mathrm{H} 8 \cdots \mathrm{S} 11^{\# 5}$ & 0.95 & $2.91(3)$ & $3.843(3)$ & $168.1(3)$ \\
\hline $\mathrm{C} 23-\mathrm{H} 23 \cdots \mathrm{Pt1}{ }^{\# 3}$ & 0.95 & $3.01(2)$ & $3.784(2)$ & $139.7(3)$ \\
\hline $\mathrm{Cg} 3 \cdots \mathrm{N}^{\#}{ }^{\# 4}$ & & & 3.103 & \\
\hline$P t 1 \cdots P t 2^{\# 1}$ & & & 5.860 & \\
\hline
\end{tabular}

Symmetry transformations used to generate equivalent atoms: $\# 1-x+0.33,-y+0.66$, $z+0.66$; \#2 $-x+0.33,-y+0.66,-z+1.66$; \#3 $-y+0.66,+x-y+0.33, z-0.33$; \#4 $-x+y+0.33$, $x+0.66, \quad z-0.66 ; \# 5 x-y, x,-z+1 . \quad C g 1$ is the centroid involving the atoms $\mathrm{N} 2 / \mathrm{C} 21 / \mathrm{N} 1 / \mathrm{C} 6 / \mathrm{N} 3 / \mathrm{C} 10 / \mathrm{C} 9 / \mathrm{C} 8 ; \quad \mathrm{Cg} 2$ is the centroid involving the atoms $\mathrm{C} 8 / \mathrm{C} 9 / \mathrm{C} 10 / \mathrm{C} 32 ; \mathrm{Cg} 3$ is the centroid involving the atoms $\mathrm{C} 6$ and $\mathrm{N} 1$. 


\section{Section S6: Photophysical characterization of $[\mathrm{PtCl}(\mathrm{L})]$ and $[\mathrm{PtCN}(\mathrm{L})]$}

Absorption spectra were measured on a Varian Cary 100 double-beam UV-Vis-NIR spectrometer and baseline-corrected. Steady-state excitation and emission spectra were recorded on a FluoTime300 spectrometer from PicoQuant equipped with a $300 \mathrm{~W}$ ozone-free Xe lamp (250-900 nm), a $10 \mathrm{~W}$ Xe flash-lamp (250-900 nm, pulse width < $10 \mu \mathrm{s}$ ) with repetition rates of $0.1-300 \mathrm{~Hz}$, an excitation monochromator (CzernyTurner $2.7 \mathrm{~nm} / \mathrm{mm}$ dispersion, 1200 grooves $/ \mathrm{mm}$, blazed at $300 \mathrm{~nm}$ ), diode lasers (pulse width < $80 \mathrm{ps)}$ ) operated by a computer-controlled laser driver PDL-820 (repetition rate up to $80 \mathrm{MHz}$, burst mode for slow and weak decays), two emission monochromators (Czerny-Turner, selectable gratings blazed at $500 \mathrm{~nm}$ with $2.7 \mathrm{~nm} / \mathrm{mm}$ dispersion and 1200 grooves $/ \mathrm{mm}$, or blazed at $1250 \mathrm{~nm}$ with $5.4 \mathrm{~nm} / \mathrm{mm}$ dispersion and 600 grooves $/ \mathrm{mm}$ ), Glan-Thompson polarizers for excitation (Xe-lamps) and emission, a Peltier-thermostatized sample holder from Quantum Northwest ($40{ }^{\circ} \mathrm{C}-105^{\circ} \mathrm{C}$ ), and two detectors, namely a PMA Hybrid 40 (transit time spread FWHM $<120$ ps, $300-720 \mathrm{~nm}$ ) and a R5509-42 NIR-photomultiplier tube (transit time spread FWHM $1.5 \mathrm{~ns}, 300-1400 \mathrm{~nm}$ ) with external cooling $\left(-80^{\circ} \mathrm{C}\right)$ from Hamamatsu. Steady-state and fluorescence lifetimes were recorded in TCSPC mode by a PicoHarp 300 (minimum base resolution $4 \mathrm{ps}$ ). Emission and excitation spectra were corrected for source intensity (lamp and grating) by standard correction curves. Lifetime analysis was performed using the commercial FluoFit software. The quality of the fit was assessed by minimizing the reduced chi squared function $(x 2)$ and visual inspection of the weighted residuals and their autocorrelation. Luminescence quantum yields were measured with a Hamamatsu Photonics absolute PL quantum yield measurement system (C9920-02) equipped with a L9799-01 CW Xenon light source (150 W), monochromator, C7473 photonic multi-channel analyzer, integrating sphere and employing U6039-05 PLQY measurement software (Hamamatsu Photonics, Ltd., Shizuoka, Japan). All solvents used were of spectrometric grade $\left(\right.$ Uvasol $\left.^{\circledR}\right)$.

Phosphorescence Lifetime Imaging Microscopy (PLIM) Measurements and photoluminescence images were acquired using a Time-resolved confocal Fluorescence Microscopy (MicroTime 200, Picoquant $®$ ), using as excitation source a $\lambda=375 \mathrm{~nm}$ laser (for PLIM) and a Xe lamp with BP360-370 and BA520IF filters (fluorescence images). A Single Photon Avalanche Diode (SPAD) and a Hybrid-Photomultiplier Tubes (HPT) were used as detectors. A TimeHarp 260 
(Picoquant ${ }^{\circledR}$ ) was used as Time-Correlated Single Photon Counting (TCSPC). Sepia $\| \Theta$ software was used for data acquisition. Calculations were done using Origin $2018 \AA$ software.

The pure complexes were dissolved in DCM (Uvasol®) and measured in Suprasil $\circledast$ quartz tubes with septa. The composites were measured in Suprasil@ quartz tubes with septa. Single crystals of MOF-5 composites were washed with DCM (Uvasol®) and measured under $n$-hexane (Uvasol®) in Suprasil@ quartz cuvettes with septa. Deaerated samples were measured upon flushing with argon for 20 min (using the septa with a cannula). Crystals were measured in emulsion oil under the microscope.

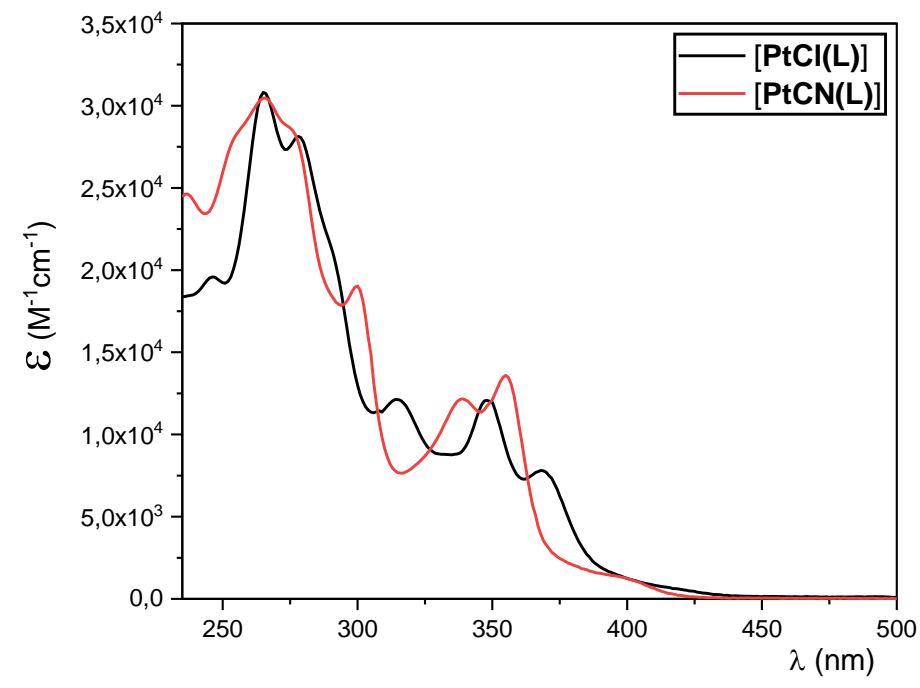

Figure S37. UV-Vis absorption spectra (molar absorption coefficient as a function of wavelength) of $[\mathrm{PtCl}(\mathrm{L})]$ and [PtCN(L)] (validity range: $\mathrm{C}=1 \times 10^{-4}-1 \times 10^{-6} \mathrm{M}$ in DCM at $298 \mathrm{~K}$ ).

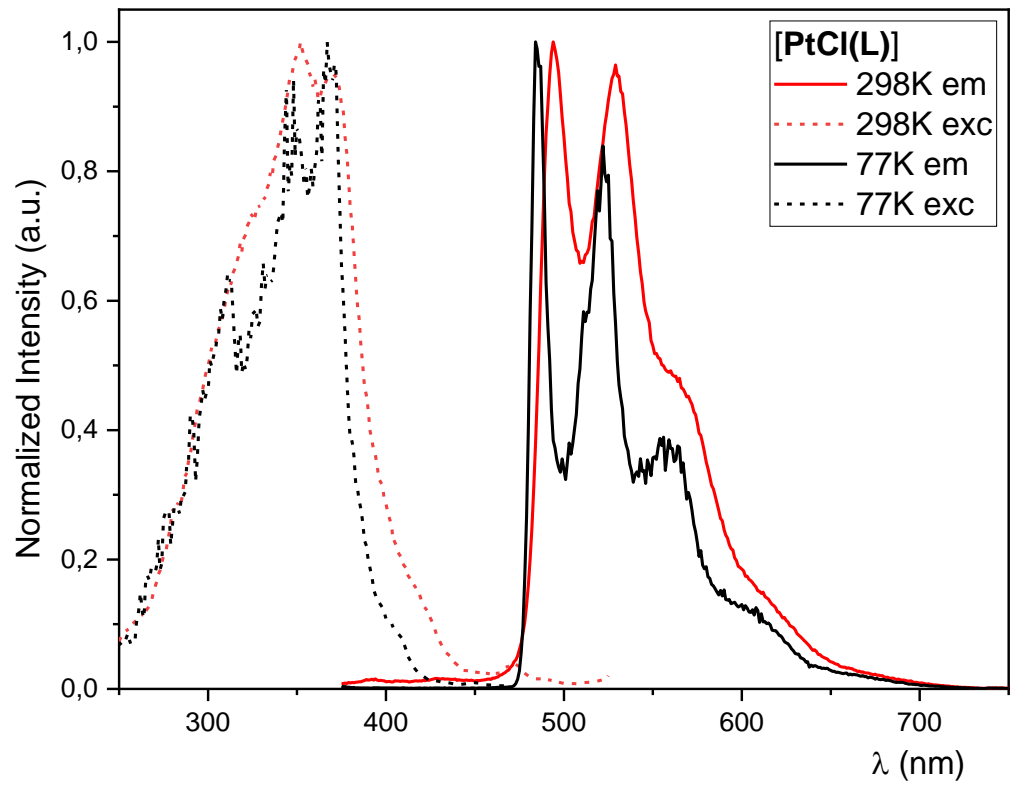

Figure S38. Excitation (dotted) and emission spectra (bold) of [PtCl(L)] $\left(\lambda_{\mathrm{exc}}=350 \mathrm{~nm}, \lambda_{\mathrm{em}}=530 \mathrm{~nm}\right)$ at $298 \mathrm{~K}$ (red) and at $77 \mathrm{~K}$ (black) in DCM. All solutions were optically diluted $(\mathrm{A}<0.1)$. Normalized to the highest intensity. 


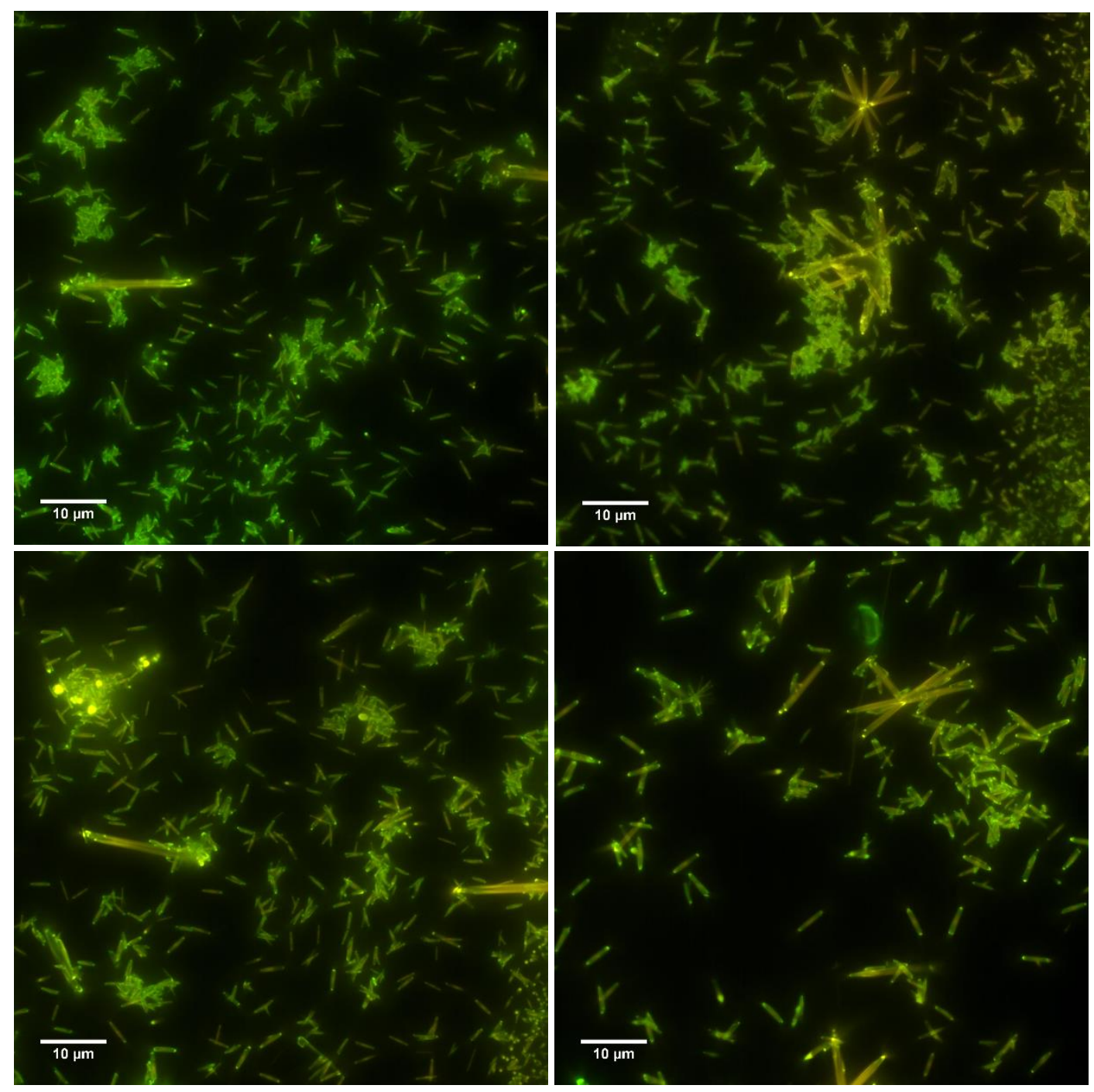

Figure S39. Luminescence micrographs of $[\mathrm{PtCl}(\mathrm{L})]$ crystals $\left(\lambda_{\mathrm{exc}}=350 \mathrm{~nm}\right)$.

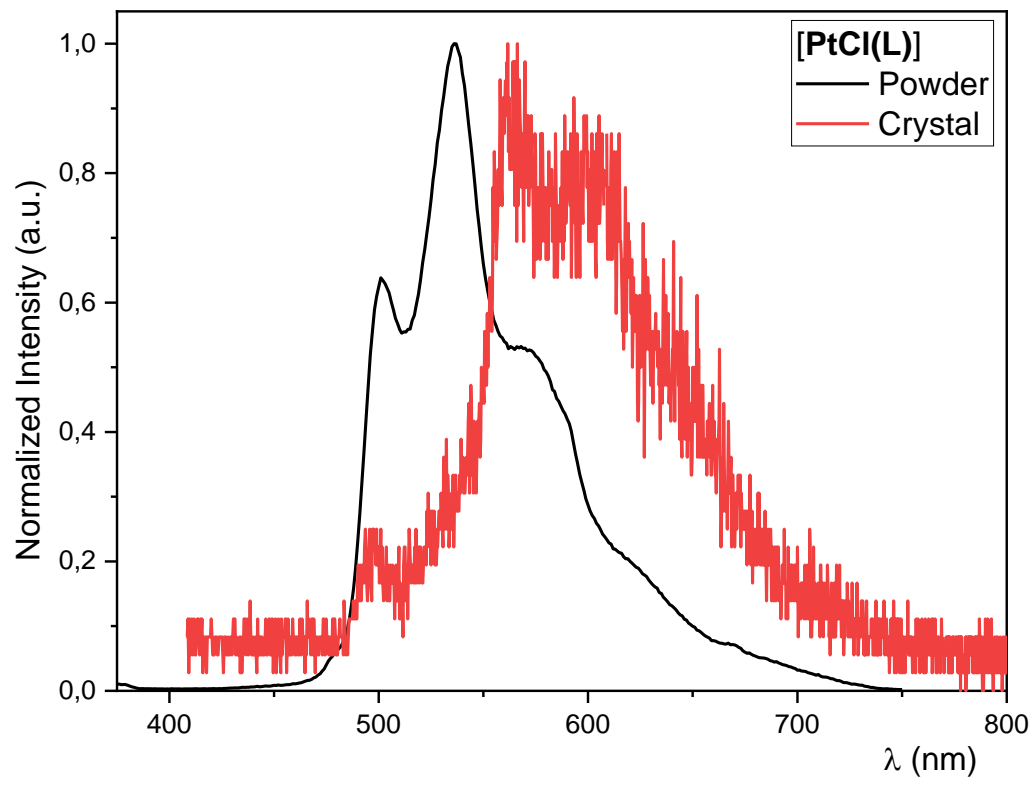

Figure S40. Emission spectra of $[\mathrm{PtCl}(\mathrm{L})]\left(\lambda_{\mathrm{exc}}=350 \mathrm{~nm}, \lambda_{\mathrm{em}}=530 \mathrm{~nm}\right)$ at $298 \mathrm{~K}$ as powder (black, spectrometer) and as crystals (red, microscope). Normalized to the highest intensity. 


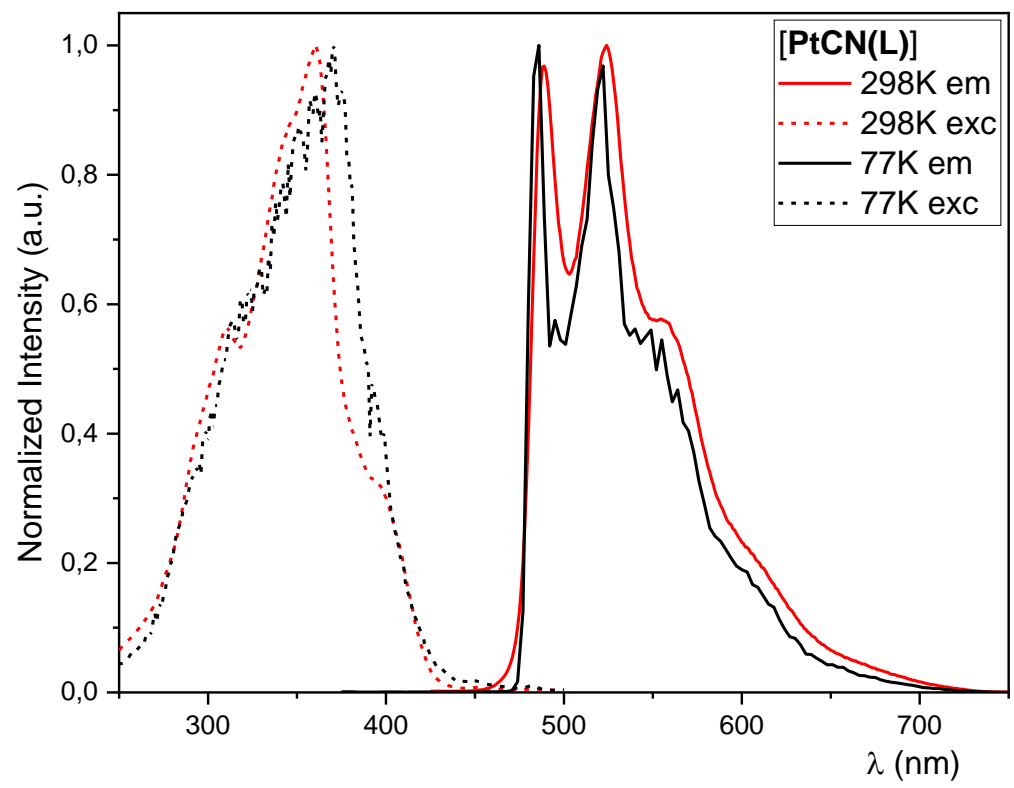

Figure S41. Excitation (dotted) and emission spectra (bold) of $[\operatorname{PtCN}(L)]\left(\lambda_{\mathrm{exc}}=350 \mathrm{~nm}, \lambda_{\mathrm{em}}=530 \mathrm{~nm}\right)$ at $298 \mathrm{~K}$ (red) and at $77 \mathrm{~K}$ (black) in DCM. All solutions were optically diluted $(\mathrm{A}<0.1)$. Normalized to the highest intensity.

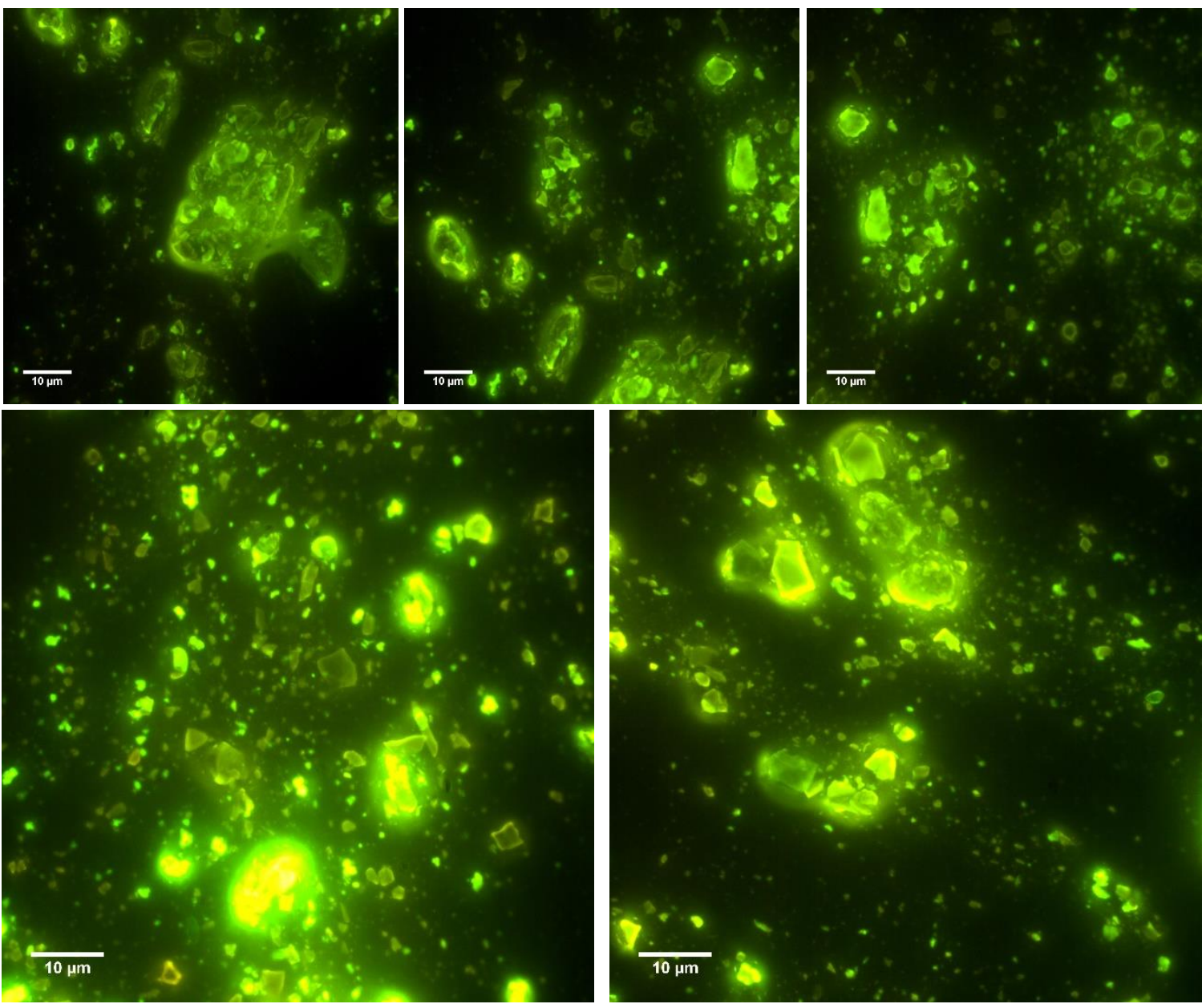

Figure S42. Luminescence micrographs of $[\operatorname{PtCN}(L)]$ crystals $\left(\lambda_{\mathrm{exc}}=350 \mathrm{~nm}\right)$. 


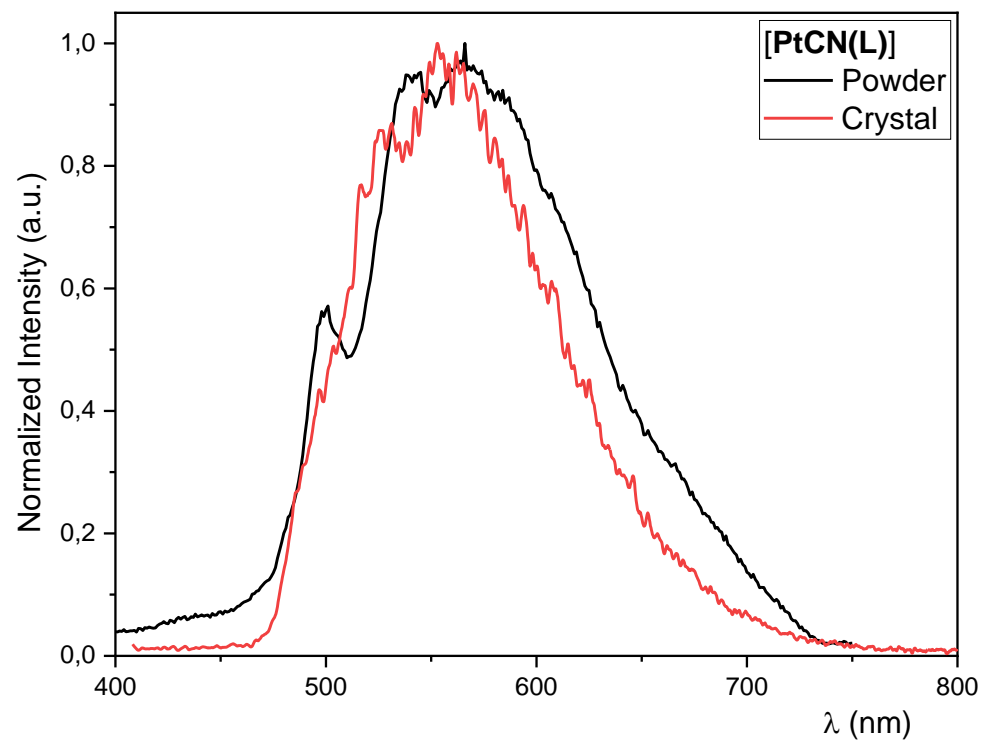

Figure S43. Emission spectra of $[\mathrm{PtCN}(\mathrm{L})]\left(\lambda_{\mathrm{exc}}=350 \mathrm{~nm}, \lambda_{\mathrm{em}}=530 \mathrm{~nm}\right)$ at $298 \mathrm{~K}$ as powder (black, spectrometer) and as crystals (red, microscope). Normalized to the highest intensity.

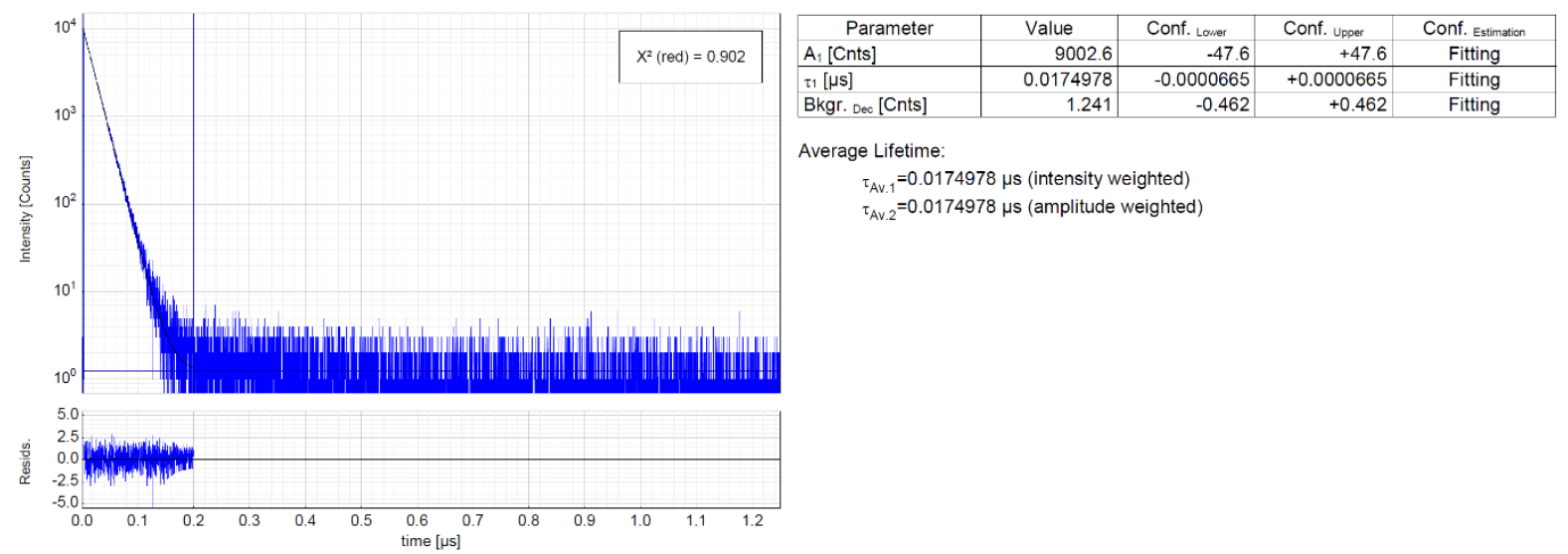

Figure S44. Left: Time-resolved luminescence decay of $[\mathrm{PtCl}(\mathrm{L})]$ in aerated $\mathrm{DCM}$ at $298 \mathrm{~K}$, including the residuals $\left(\lambda_{\mathrm{exc}}=376.7 \mathrm{~nm}, \lambda_{\mathrm{em}}=530 \mathrm{~nm}\right)$. Right: Fitting parameters including pre-exponential factors and confidence limits.

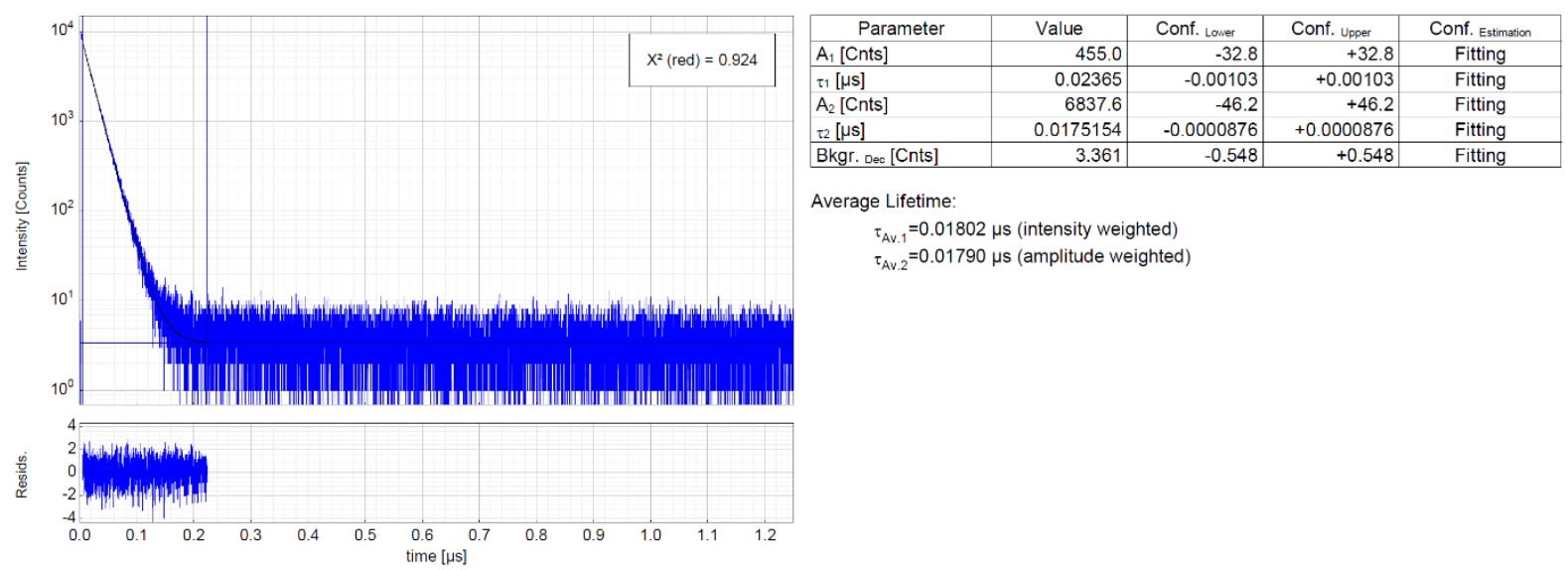

Figure S45. Left: Time-resolved luminescence decay of $[\mathrm{PtCl}(\mathrm{L})]$ in deaerated $\mathrm{DCM}$ at $298 \mathrm{~K}$, including the residuals $\left(\lambda_{\mathrm{exc}}=376.7 \mathrm{~nm}, \lambda_{\mathrm{em}}=530 \mathrm{~nm}\right)$. Right: Fitting parameters including pre-exponential factors and confidence limits. 


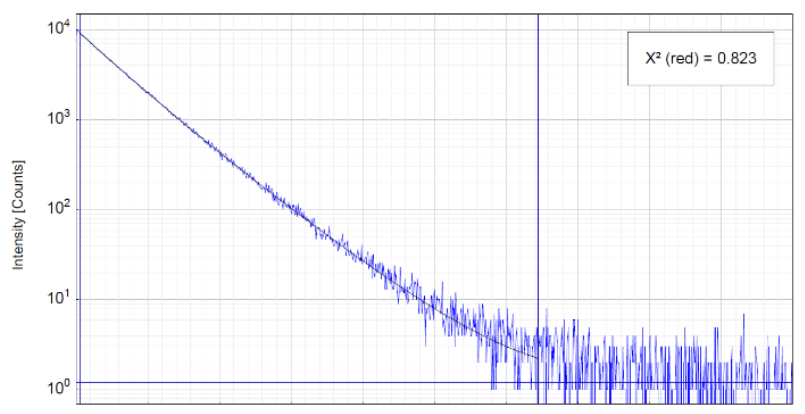

\begin{tabular}{|c|c|c|c|c|}
\hline Parameter & Value & Conf. Lower & Conf. Upper & Conf. Estimation \\
\hline $\mathrm{A}_{1}[\mathrm{Cnts}]$ & 3670.2 & -34.4 & +34.4 & Fitting \\
\hline$\tau 1[\mu \mathrm{s}]$ & 38.866 & -0.227 & +0.227 & Fitting \\
\hline $\mathrm{A}_{2}$ [Cnts] & 5423.5 & -51.1 & +51.1 & Fitting \\
\hline$\tau_{2}[\mu \mathrm{s}]$ & 25.985 & -0.207 & +0.207 & Fitting \\
\hline Bkgr. Dec [Cnts] & 1.214 & -0.601 & +0.601 & Fitting \\
\hline
\end{tabular}

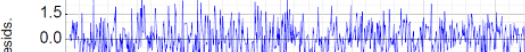

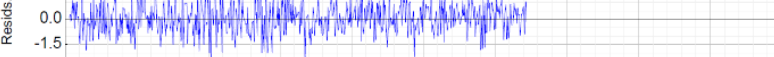

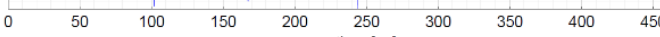

$=31.184 \mu \mathrm{s}$ (amplitude weighted)

Figure S46. Left: Time-resolved luminescence decay of $[\mathrm{PtCl}(\mathrm{L})]$ in a frozen glassy matrix of $\mathrm{DCM} / \mathrm{MeOH}(\mathrm{V}: \mathrm{V}=$ $1: 1)$ at $77 \mathrm{~K}$, including the residuals $\left(\lambda_{\mathrm{exc}}=376.7 \mathrm{~nm}, \lambda_{\mathrm{em}}=530 \mathrm{~nm}\right)$. Right: Fitting parameters including preexponential factors and confidence limits.

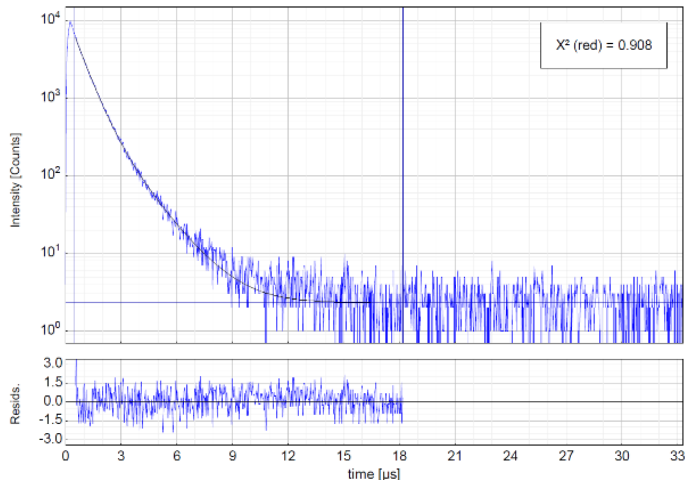

\begin{tabular}{|l|r|r|r|c|}
\hline \multicolumn{1}{|c|}{ Parameter } & Value & Conf. Lower & Conf. Upper & Conf. Estimation \\
\hline $\mathrm{A}_{1}[\mathrm{Cnts}]$ & 857.7 & -25.0 & +25.0 & Fitting \\
\hline$\tau_{1}[\mu \mathrm{s}]$ & 1.4676 & -0.0233 & +0.0233 & Fitting \\
\hline $\mathrm{A}_{2}[\mathrm{Cnts}]$ & 5153.4 & -64.6 & +64.6 & Fitting \\
\hline$\tau_{2}[\mu \mathrm{s}]$ & 0.62743 & -0.00681 & +0.00681 & Fitting \\
\hline Bkgr. Dec [Cnts] & 2.305 & -0.392 & +0.392 & Fitting \\
\hline
\end{tabular}

Average Lifetime:

$\tau_{\mathrm{Av} .1}=0.8629 \mu \mathrm{s}$ (intensity weighted)

$\tau_{\text {Av. } 2}=0.7473 \mu \mathrm{s}$ (amplitude weighted)

Figure S47. Left: Time-resolved luminescence decay of $[\mathrm{PtCl}(\mathrm{L})]$ as a solid powder at $298 \mathrm{~K}$ (air equilibrated), including the residuals $\left(\lambda_{\mathrm{exc}}=376.7 \mathrm{~nm}, \lambda_{\mathrm{em}}=530 \mathrm{~nm}\right)$. Right: Fitting parameters including pre-exponential factors and confidence limits.

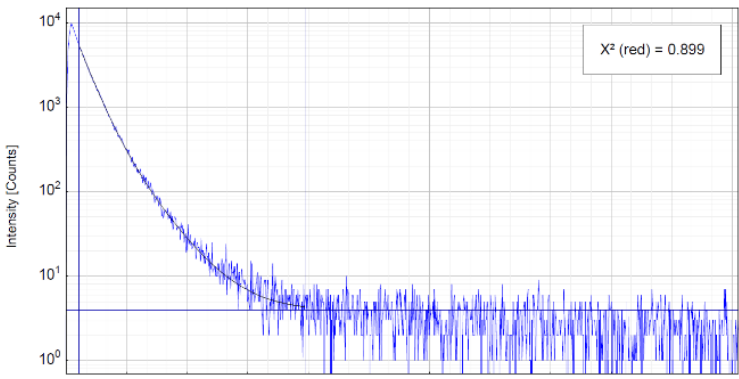

\begin{tabular}{|l|r|r|r|r|}
\hline \multicolumn{1}{|c|}{ Parameter } & \multicolumn{1}{c|}{ Value } & \multicolumn{1}{c|}{ Conf. Lower } & \multicolumn{1}{c|}{ Conf. Upper } & Conf. Estimation \\
\hline $\mathrm{A}_{1}[\mathrm{Cnts}]$ & 926.4 & -20.0 & +20.0 & Fitting \\
\hline$\tau 1$ [ $[\mu \mathrm{s}]$ & 1.4413 & -0.0178 & +0.0178 & Fitting \\
\hline $\mathrm{A}_{2}[\mathrm{Cnts}]$ & 4230.1 & -46.7 & +46.7 & Fitting \\
\hline$\tau 2[\mu \mathrm{s}]$ & 0.65183 & -0.00631 & +0.00631 & Fitting \\
\hline Bkgr. Dec [Cnts] & 3.939 & -0.606 & +0.606 & Fitting \\
\hline
\end{tabular}

Average Lifetime:

$\tau_{\mathrm{Av} .1}=0.9094 \mu \mathrm{s}$ (intensity weighted)

$\tau_{\mathrm{Av} 2}=0.7936 \mu \mathrm{s}$ (amplitude weighted)

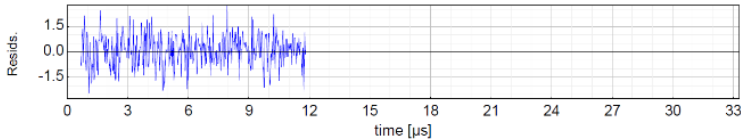

Figure S48. Left: Time-resolved luminescence decay of $[\mathrm{PtCl}(\mathrm{L})]$ as a solid powder at $298 \mathrm{~K}$ (argon atmosphere), including the residuals $\left(\lambda_{\mathrm{exc}}=376.7 \mathrm{~nm}, \lambda_{\mathrm{em}}=530 \mathrm{~nm}\right)$. Right: Fitting parameters including pre-exponential factors and confidence limits. 


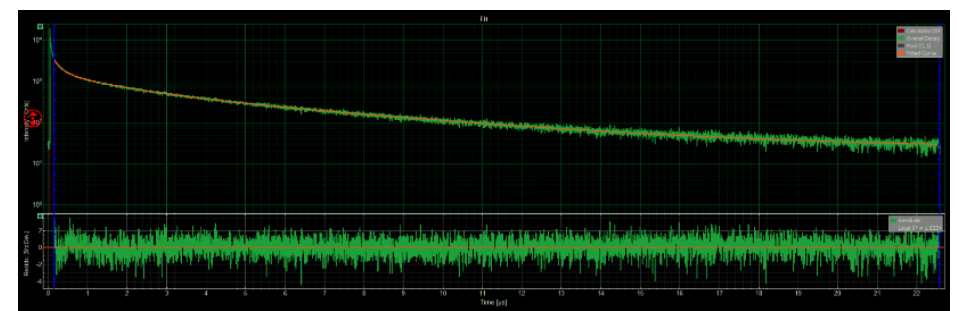

$$
\begin{aligned}
& \tau_{1}=4800 \pm 100 \mathrm{~ns}(38 \%) \\
& \tau_{2}=1260 \pm 40 \mathrm{~ns}(52 \%) \\
& \tau_{3}=180 \pm 80 \mathrm{~ns}(10 \%) \\
& \tau_{\text {av }}(\text { Amplitude weighted })=1440 \pm 140 \mathrm{~ns}
\end{aligned}
$$

Figure S49. Left: Time-resolved luminescence decay of $[\mathrm{PtCl}(\mathrm{L})]$ as crystals at $298 \mathrm{~K}$ (argon atmosphere), including the residuals $\left(\lambda_{\mathrm{exc}}=375 \mathrm{~nm}, \lambda_{\mathrm{em}}=530 \mathrm{~nm}\right)$. Right: Fitting parameters including pre-exponential factors and confidence limits.
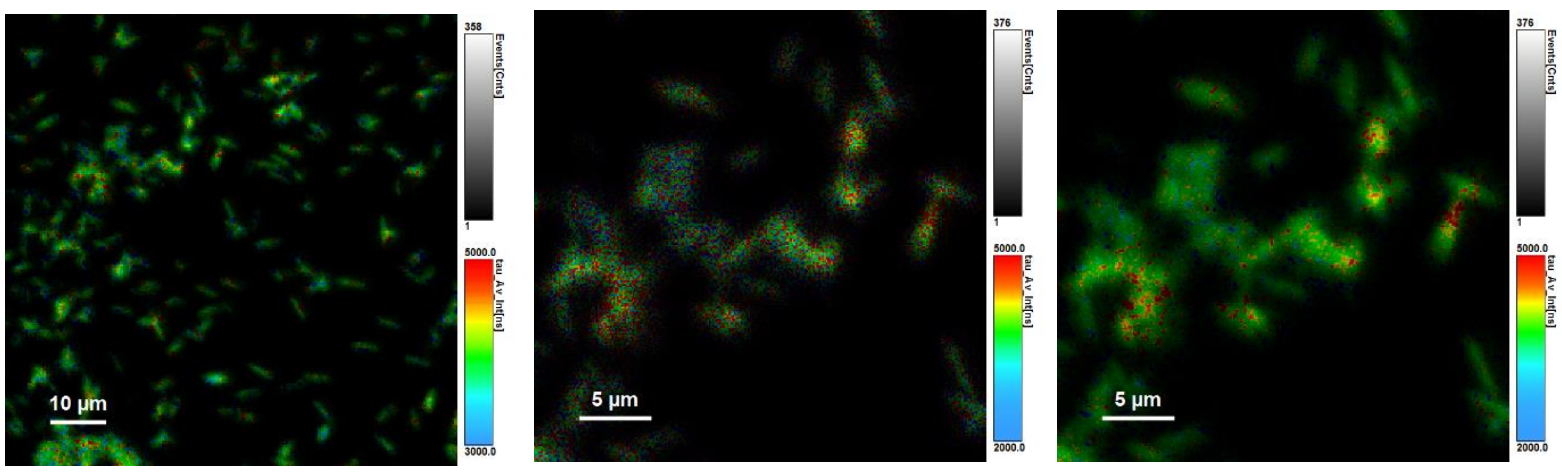

Figure S50. Phosphorescence lifetime maps obtained by time-resolved photoluminescence confocal microscopy of $[\mathrm{PtCl}(\mathrm{L})]$ as a crystal at room temperature $\left(\lambda_{\mathrm{exc}}=375 \mathrm{~nm}, \lambda_{\mathrm{em}}=530 \mathrm{~nm}\right)$.

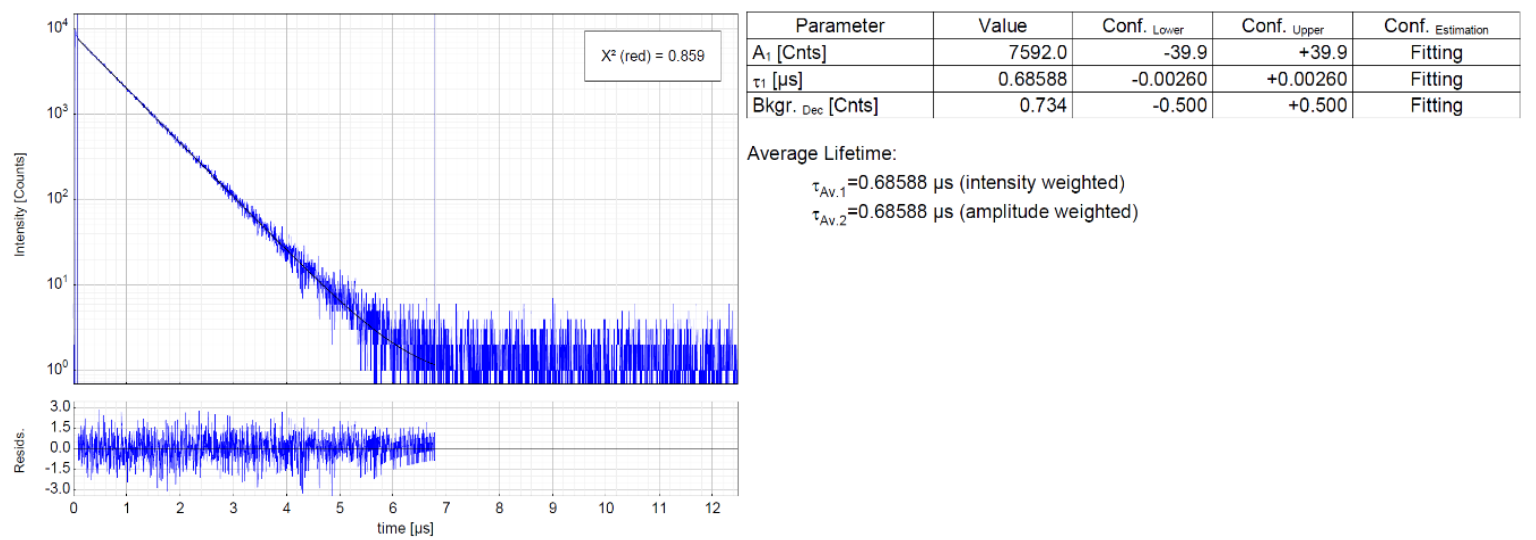

Figure S51. Left: Time-resolved luminescence decay of [PtCN(L)] in aerated DCM at $298 \mathrm{~K}$, including the residuals $\left(\lambda_{\mathrm{exc}}=376.7 \mathrm{~nm}, \lambda_{\mathrm{em}}=530 \mathrm{~nm}\right)$. Right: Fitting parameters including pre-exponential factors and confidence limits.

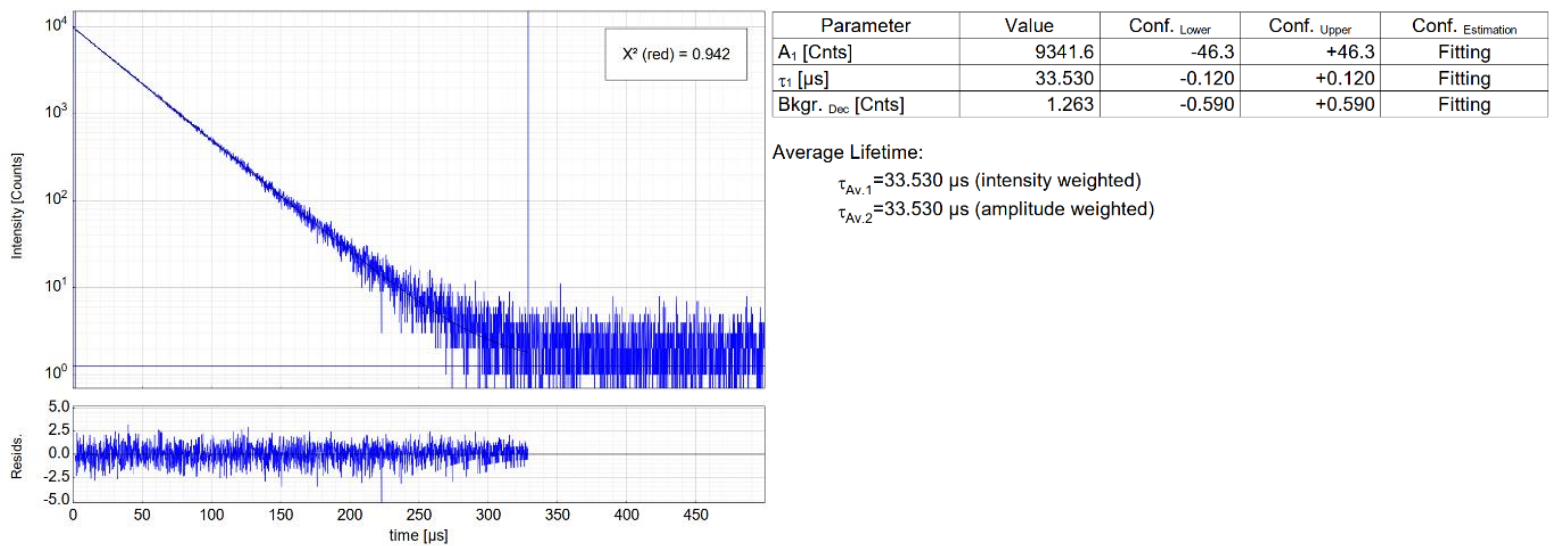

Figure S52. Left: Time-resolved luminescence decay of [PtCN(L)] in deaerated DCM at $298 \mathrm{~K}$, including the residuals $\left(\lambda_{\mathrm{exc}}=376.7 \mathrm{~nm}, \lambda_{\mathrm{em}}=530 \mathrm{~nm}\right)$. Right: Fitting parameters including pre-exponential factors and confidence limits. 


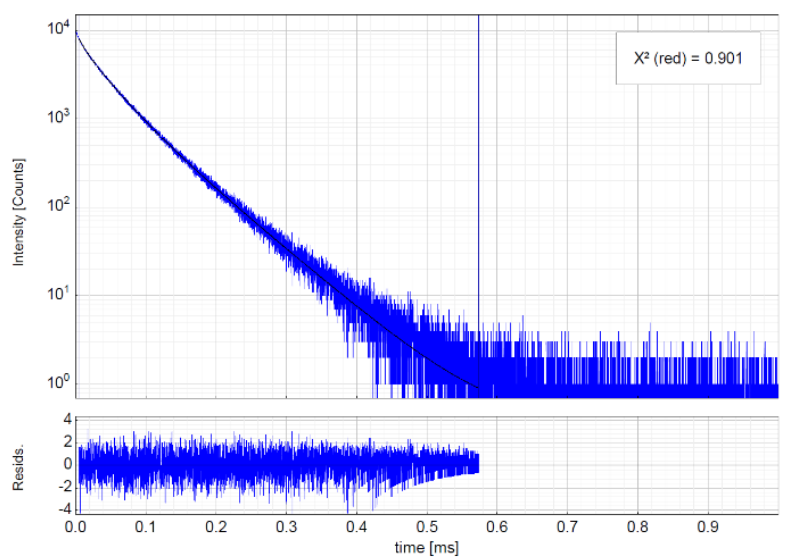

\begin{tabular}{|c|c|c|c|c|}
\hline Parameter & Value & Conf. Lower & Conf. upper & Conf. Estimation \\
\hline$A_{1}[\mathrm{Cnts}]$ & 2932.3 & -30.7 & +30.7 & Fitting \\
\hline$\tau_{1}[\mathrm{~ms}]$ & 0.065797 & -0.000429 & +0.000429 & Fitting \\
\hline $\mathrm{A}_{2}$ [Cnts] & 4073.2 & -58.8 & +58.8 & Fitting \\
\hline$\tau_{2}[\mathrm{~ms}]$ & 0.033712 & -0.000440 & +0.000440 & Fitting \\
\hline $\mathrm{A}_{3}[\mathrm{Cnts}]$ & 1010 & -146 & +146 & Fitting \\
\hline$\tau_{3}[\mathrm{~ms}]$ & 0.00831 & -0.00150 & +0.00150 & Fitting \\
\hline Bkgr. Dec [Cnts] & 0.387 & -0.482 & +0.482 & Fitting \\
\hline \multicolumn{5}{|c|}{ Average Lifetime: } \\
\hline
\end{tabular}

Figure S53. Left: Time-resolved luminescence decay of $[\mathrm{PtCN}(\mathrm{L})]$ in a frozen glassy matrix of $\mathrm{DCM} / \mathrm{MeOH}(\mathrm{V}: \mathrm{V}=$ $1: 1)$ at $77 \mathrm{~K}$, including the residuals $\left(\lambda_{\mathrm{exc}}=376.7 \mathrm{~nm}, \lambda_{\mathrm{em}}=530 \mathrm{~nm}\right)$. Right: Fitting parameters including preexponential factors and confidence limits.

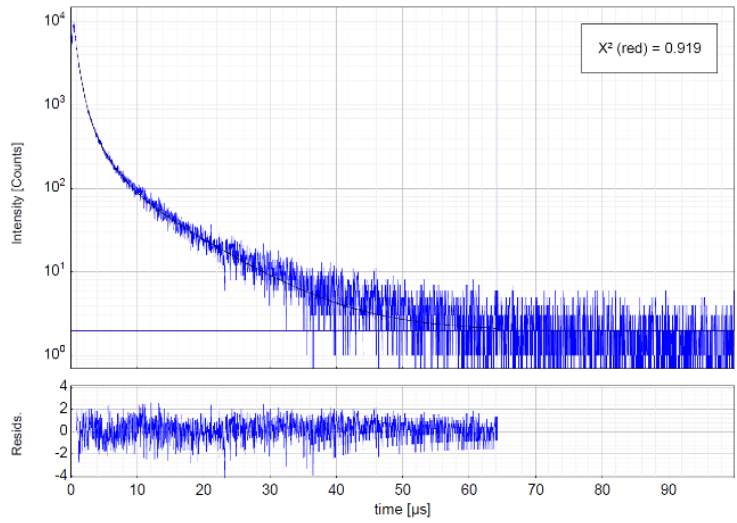

\begin{tabular}{|l|r|r|r|c|}
\multicolumn{1}{c|}{ Parameter } & \multicolumn{1}{c|}{ Value } & \multicolumn{1}{c|}{ Conf. Lower } & Conf. Upper & Conf. Estimation \\
\hline $\mathrm{A}_{1}[\mathrm{Cnts}]$ & 204.21 & -8.10 & +8.10 & Fitting \\
\hline$\tau_{1}[\mu \mathrm{s}]$ & 8.696 & -0.220 & +0.220 & Fitting \\
\hline $\mathrm{A}_{2}[\mathrm{Cnts}]$ & 1027.8 & -39.8 & +39.8 & Fitting \\
\hline$\tau_{2}[\mu \mathrm{s}]$ & 2.2114 & -0.0653 & +0.0653 & Fitting \\
\hline $\mathrm{A}_{3}[\mathrm{Cnts}]$ & 3656 & -118 & +118 & Fitting \\
\hline$\tau_{3}[\mu \mathrm{s}]$ & 0.6304 & -0.0207 & +0.0207 & Fitting \\
\hline Bkgr. Dec [Cnts] & 1.978 & -0.422 & +0.422 & Fitting \\
\hline
\end{tabular}

Average Lifetime:

$$
\tau_{\mathrm{Av} .1}=3.450 \mu \mathrm{s} \text { (intensity weighted) }
$$

$\tau_{\text {Av.2 }}=1.300 \mu$ s (amplitude weighted)

Figure S54. Left: Time-resolved luminescence decay of [PtCN(L)] as a solid powder at $298 \mathrm{~K}$ (air equilibrated), including the residuals $\left(\lambda_{\mathrm{exc}}=376.7 \mathrm{~nm}, \lambda_{\mathrm{em}}=530 \mathrm{~nm}\right)$. Right: Fitting parameters including pre-exponential factors and confidence limits.

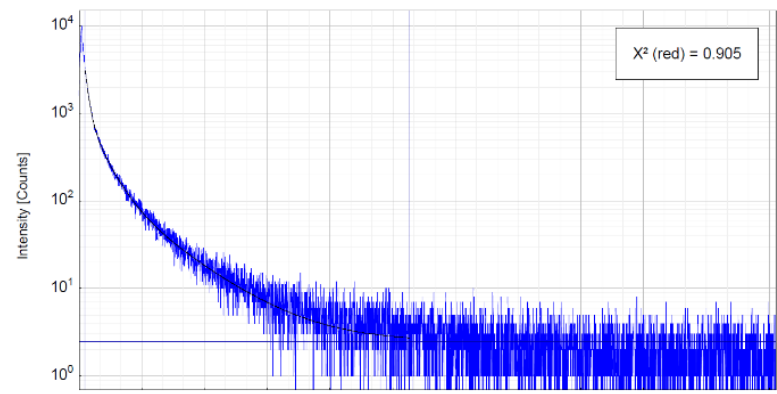

\begin{tabular}{|c|c|c|c|c|}
\hline Parameter & Value & Conf. Lower & Conf. Upper & Conf. Estimation \\
\hline$A_{1}[\mathrm{Cnts}]$ & 169.49 & -7.31 & +7.31 & Fitting \\
\hline$\tau_{1}[\mu \mathrm{s}]$ & 12.005 & -0.331 & +0.331 & Fitting \\
\hline $\mathrm{A}_{2}$ [Cnts] & 830.6 & -28.9 & +28.9 & Fitting \\
\hline$\tau_{2}[\mu \mathrm{s}]$ & 3.5850 & -0.0987 & +0.0987 & Fitting \\
\hline $\mathrm{A}_{3}[\mathrm{Cnts}]$ & 2491.2 & -98.6 & +98.6 & Fitting \\
\hline$\tau 3[\mu \mathrm{s}]$ & 0.8212 & -0.0341 & +0.0341 & Fitting \\
\hline Bkgr. Dec [Cnts] & 2.464 & -0.463 & +0.463 & Fitting \\
\hline
\end{tabular}

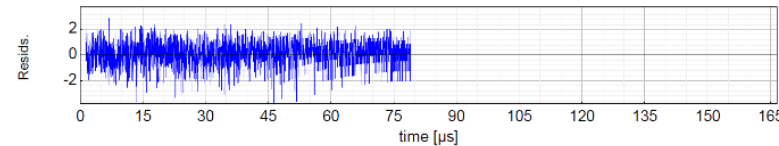

$\tau_{\mathrm{Av} .1}=5.211 \mu \mathrm{s}$ (intensity weighted)

Figure S55. Left: Time-resolved luminescence decay of [PtCN(L)] as a solid powder at $298 \mathrm{~K}$ (argon atmosphere), including the residuals $\left(\lambda_{\mathrm{exc}}=376.7 \mathrm{~nm}, \lambda_{\mathrm{em}}=530 \mathrm{~nm}\right)$. Right: Fitting parameters including pre-exponential factors and confidence limits. 


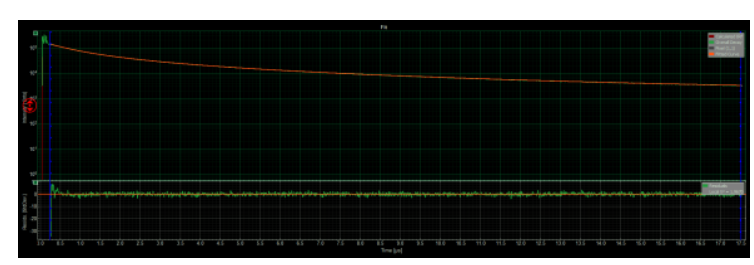

$$
\begin{aligned}
& \tau_{1}=5600 \pm 400 \mathrm{~ns}(22 \%) \\
& \tau_{2}=1450 \pm 120 \mathrm{~ns}(43 \%) \\
& \tau_{3}=400 \pm 40 \mathrm{~ns}(35 \%) \\
& \tau_{\mathrm{av}} \text { (Amplitude weighted) }=2040 \pm 140 \mathrm{~ns}
\end{aligned}
$$

Figure S56. Left: Time-resolved luminescence decay of [PtCN(L)] as crystals at $298 \mathrm{~K}$ (argon atmosphere), including the residuals $\left(\lambda_{\mathrm{exc}}=375 \mathrm{~nm}, \lambda_{\mathrm{em}}=530 \mathrm{~nm}\right)$. Right: Fitting parameters including pre-exponential factors and confidence limits.
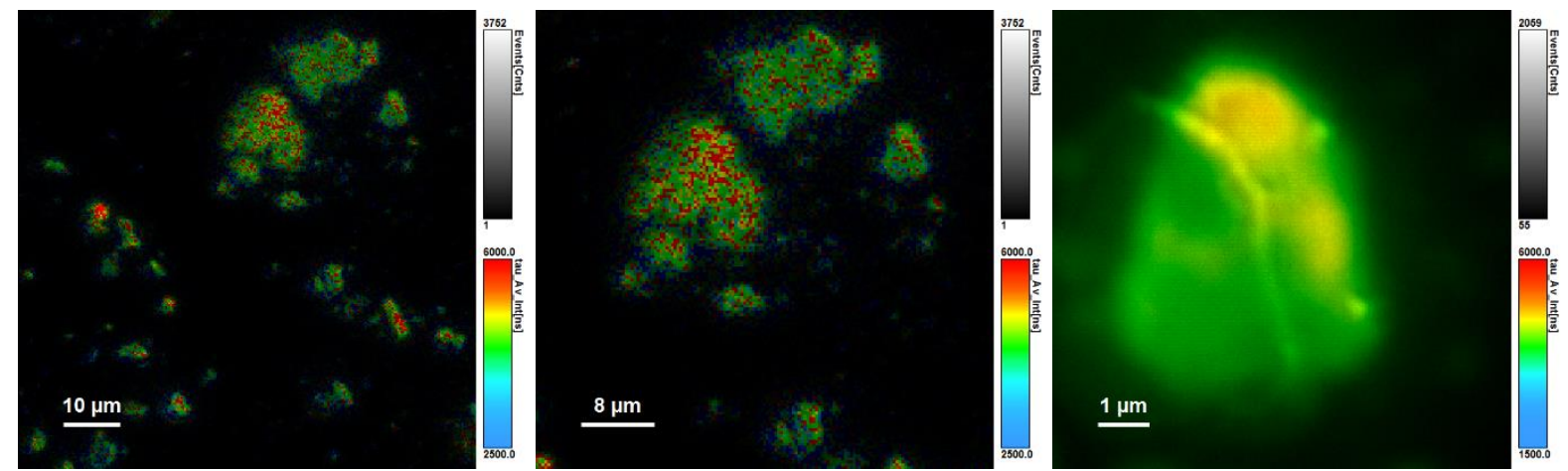

Figure S57. Phosphorescence lifetime maps obtained by time-resolved photoluminescence confocal microscopy [PtCN(L)] as crystals at $298 \mathrm{~K}\left(\lambda_{\mathrm{exc}}=375 \mathrm{~nm}, \lambda_{\mathrm{em}}=530 \mathrm{~nm}\right)$. 


\section{Section S7: Synthesis and characterization of $[\mathrm{PtCl}(\mathrm{L})] @ M O F$ and [PtCN(L)]@MOF}

ZIF-8 was synthesized following a procedure of Wiebcke and co-workers ${ }^{10} 79 \mathrm{mg}$ $(0.266 \mathrm{mmol})$ of $\mathrm{Zn}\left(\mathrm{NO}_{3}\right) \cdot 6 \mathrm{H}_{2} \mathrm{O}$ and $130 \mathrm{mg}(1.584 \mathrm{mmol})$ of 2-methylimidazole in 20 $\mathrm{mL}$ methanol each were rapidly mixed and stirred for $1 \mathrm{~h}$. The resulting turbid solution was centrifuged for 10 min and the solid residue was washed with fresh methanol twice and with DCM once. The solid was dried at $40{ }^{\circ} \mathrm{C}$ in air overnight. Yield: $10.3 \pm 0.2 \mathrm{mg}$ (13\%), PXRD: Figure S58, N2 sorption: Figure S60, SEM: Figure S66.

MOF-5 was prepared following a procedure described by Yaghi and co-workers ${ }^{11}$ All steps were performed under $\mathrm{N}_{2}$-atmosphere. $1799 \mathrm{mg}(7.74 \mathrm{mmol})$ of $\mathrm{Zn}(\mathrm{OAc})_{2} \cdot 2 \mathrm{H}_{2} \mathrm{O}$ were dissolved in $50 \mathrm{~mL}$ of DMF. Over a period of $15 \mathrm{~min}$ the solution was added to a solution of $506 \mathrm{mg}(3.05 \mathrm{mmol})$ of terephthalic acid and $0.85 \mathrm{~mL}$ of triethylamine in $40 \mathrm{~mL}$ of DMF. The mixture was stirred for $2.5 \mathrm{~h}$, centrifuged for $10 \mathrm{~min}$, the supernatant decanted, $10 \mathrm{~mL}$ DMF were added let stand overnight. After centrifugation again, the solid residue was washed with DCM over 8 days. The solvent volume of 10 $\mathrm{mL}$ was replaced with fresh solvent $(10 \mathrm{~mL})$ after 2,3 and last 7 days. The product was dried overnight at room temperature under vacuum and stored under Ar atmosphere. Yield: $105 \pm 5$ mg (33\%), PXRD: Figure S59, N2-sorption: Figure S63, SEM: Figure S71.

MOF-5 single crystals were prepared following a procedure described by Grzybowski and co-workers ${ }^{12}$ In a $50 \mathrm{~mL}$ Erlenmeyer flask, $308 \mathrm{mg}(1.035 \mathrm{mmol})$ of $\mathrm{Zn}\left(\mathrm{NO}_{3}\right)_{2} \cdot 6 \mathrm{H}_{2} \mathrm{O}$ and $58 \mathrm{mg}(0.348 \mathrm{mmol})$ of terephthalic acid were dissolved in $8.8 \mathrm{~mL}$ of DEF. After 20 minutes the solution was transferred to two $10 \mathrm{~mL}$ Pyrex ${ }^{\circledR}$ flasks through a syringe filter. The flasks were kept at $85^{\circ} \mathrm{C}$ for $72 \mathrm{~h}$ and cooled to room temperature over $24 \mathrm{~h}$. The obtained single crystals were washed with $8.8 \mathrm{~mL}$ of DMF for $1 \mathrm{~h}$ once and thrice with $8.8 \mathrm{~mL}$ of DCM for $1 \mathrm{~h}$ each and kept in DCM for further use.

ZIF-8 composites ([PtCN(L)]@ZIF-8, [PtCl(L)]@ZIF-8) were obtained by dissolving a chosen amount of complex (1, 2, 5 or $10 \mathrm{mg}$ for $[\mathrm{PtCN}(\mathrm{L})]$ with $10 \mathrm{mg}=0.019 \mathrm{mmol})$ ] and $5 \mathrm{mg}$ for $[\mathrm{PtCl}(\mathrm{L})])$ and $79.1 \mathrm{mg}(0.266 \mathrm{mmol})$ of $\mathrm{Zn}\left(\mathrm{NO}_{3}\right)_{2} \cdot 6 \mathrm{H}_{2} \mathrm{O}$ in $4 \mathrm{~mL}$ of methanol. The solution was rapidly mixed with $130 \mathrm{mg}(1.584 \mathrm{mmol})$ of 2-methylimidazole in $4 \mathrm{~mL}$ of methanol and stirred for $1 \mathrm{~h}$. The resulting turbid solution was centrifuged for $10 \mathrm{~min}$ and the solid residue was washed thrice with fresh methanol (20 mL and $10 \mathrm{~min}$ each) and once with DCM (20 mL, $10 \mathrm{~min}$ ) and dried at $40{ }^{\circ} \mathrm{C}$ in air overnight. Yield: $11 \pm 2$ mg, PXRD: Figure S58; N2-sorption: Figure S60; SEM: Fig. 5 ([PtCN(L)]@ZIF-8); Figure S65 ([PtCl(L)]@ZIF-8).

MOF-5 composites ([PtCN(L)]@MOF-5, [PtCl(L)]@MOF-5) were obtained by postsynthetic encapsulation. All steps were performed under $\mathrm{N}_{2}$-atmosphere. $5 \mathrm{mg}$ of MOF-5 were mixed with $1 \mathrm{mg}$ of complex and kept in $2 \mathrm{~mL}$ of DCM. After $24 \mathrm{~h}$ the suspension was centrifuged for $15 \mathrm{~min}$ and the supernatant solvent was removed. The solid residue was washed thrice with fresh DCM (2 $\mathrm{mL}$ and 10 min each) and dried at room temperature for 3 hours. Yield: $4.4 \pm 0.2 \mathrm{mg}$, PXRD: Figure S59; $\mathrm{N}_{2}$-sorption: Fig. $4 \quad([\mathrm{PtCN}(\mathrm{L})] @ M O F-5) ; \quad$ Figure S63 ([PtCl(L)]@MOF-5); SEM: $\quad$ Fig. 5 ([PtCN(L)]@MOF-5); Figure S70 ([PtCl(L)]@MOF-5). 
MOF-5 single crystal composites ([PtCN(L)]@MOF-5, [PtCl(L)]@MOF-5) were obtained by incubating several single crystals (size approx. $0.5-1 \mathrm{~mm}^{3}$ ) in a solution of $1 \mathrm{mg}$ of complex in $3 \mathrm{~mL}$ of DCM. After $24 \mathrm{~h}$ the solution was replaced thrice with fresh DCM (3 $\mathrm{mL}$ each). The single crystal composites were kept in DCM for further use.
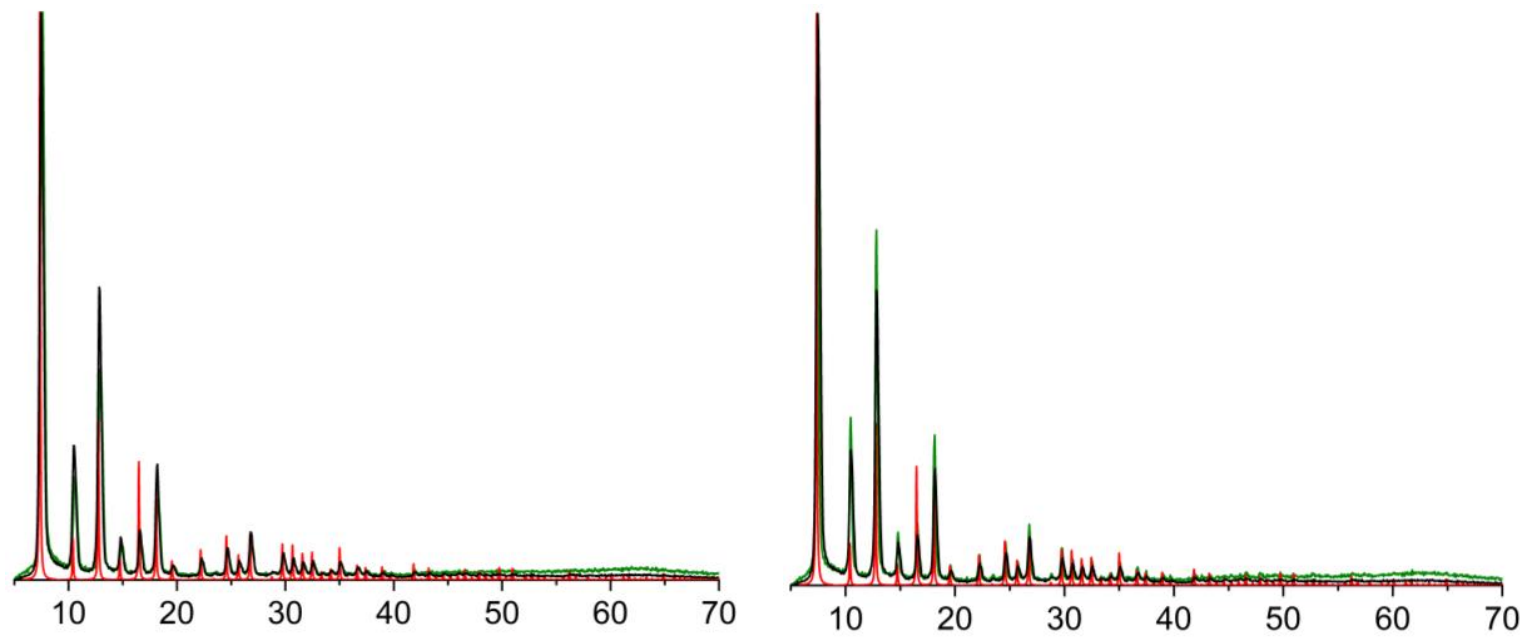

(a) $2 \Theta\left[{ }^{\circ}\right]$

(b) $2 \Theta\left[^{\circ}\right]$

Figure S58. PXRD of (a) [PtCl(L)]@ZIF-8 (green) and (b) [PtCN(L)]@ZIF-8-5 (green; "5" indicates the amount of Pt complex used in the composite synthesis), compared with pure ZIF-8 (black) and simulated ZIF-8 (red). ${ }^{13}$
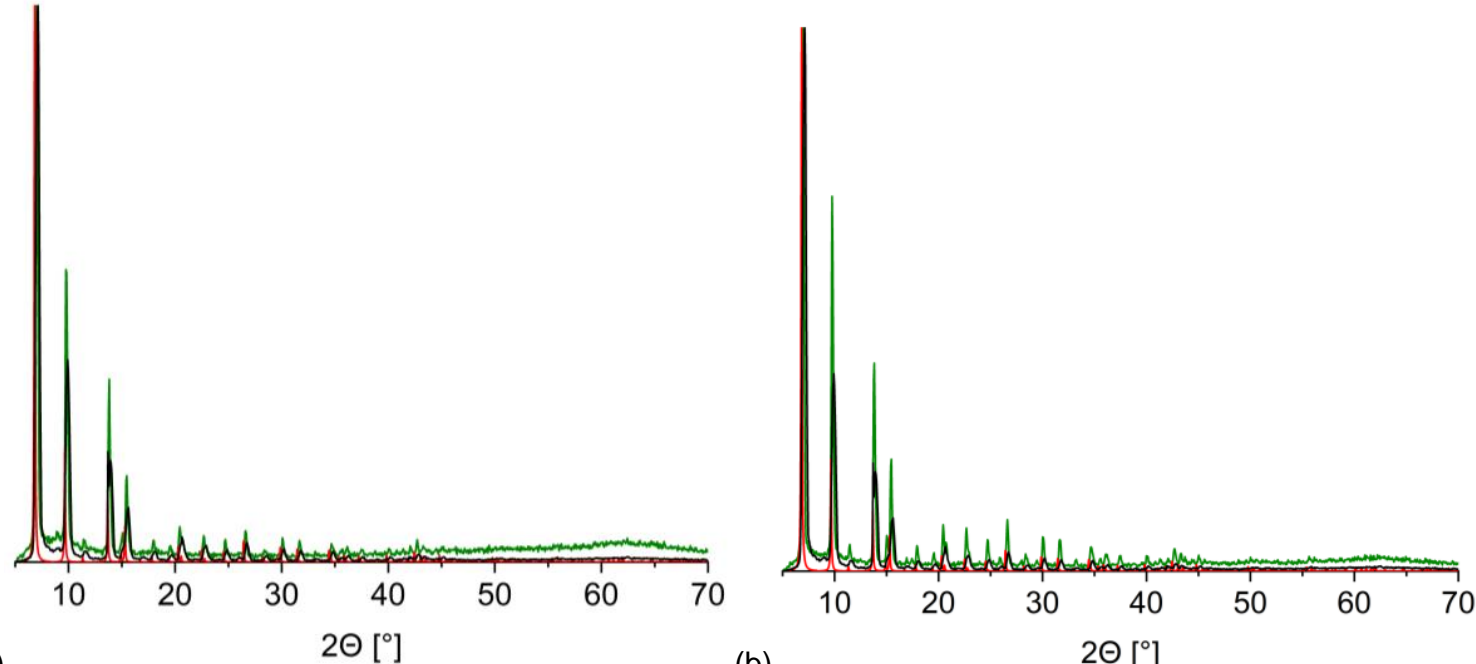

(a)

(b) $2 \Theta\left[{ }^{\circ}\right]$

Figure S59. PXRD of (a) [PtCl(L)]@MOF-5 (green) and (b) [PtCN(L)]@MOF-5 (green; powder sample), compared with pure MOF-5 (black) and simulated MOF-5 (red). ${ }^{14}$ 

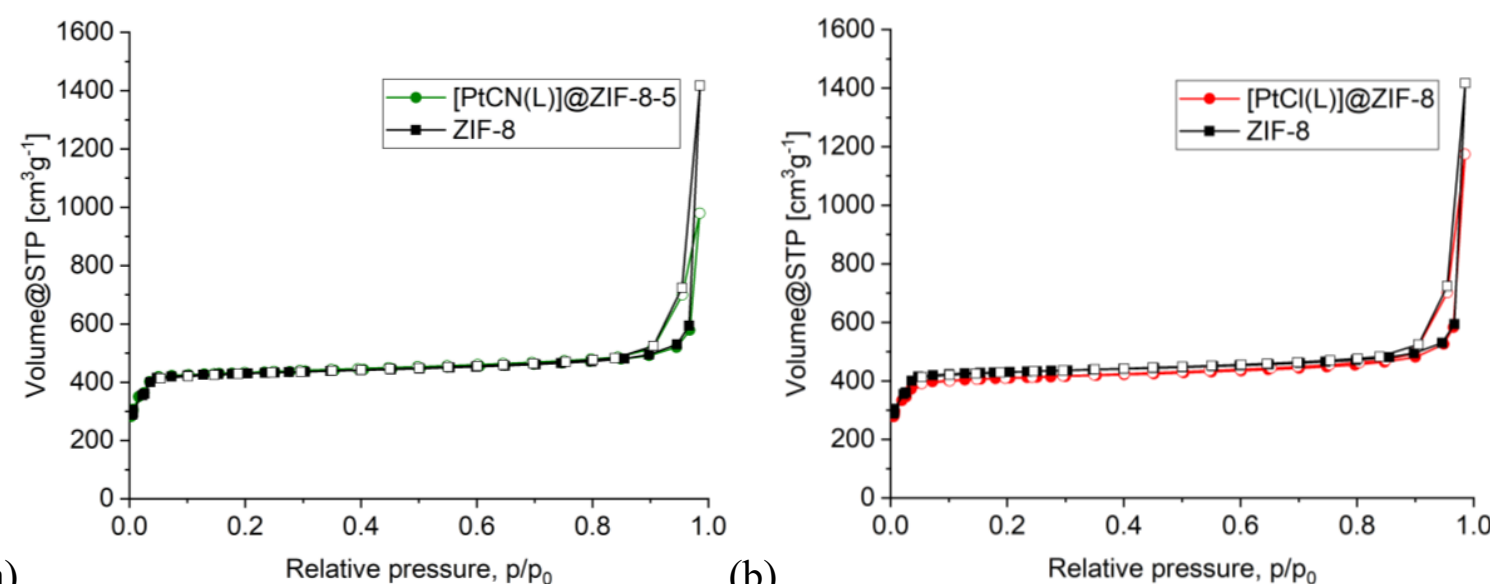

(a)

(b)

Relative pressure, $\mathrm{p} / \mathrm{p}_{0}$

Figure S60. (a) N2-Sorption isotherms of [PtCN(L)]@ZIF-8 (green circles) and (b) [PtCI(L)]@ZIF-8 (red circles) and neat ZIF-8 (black squares). Filled symbols: adsorption, open symbols: desorption.

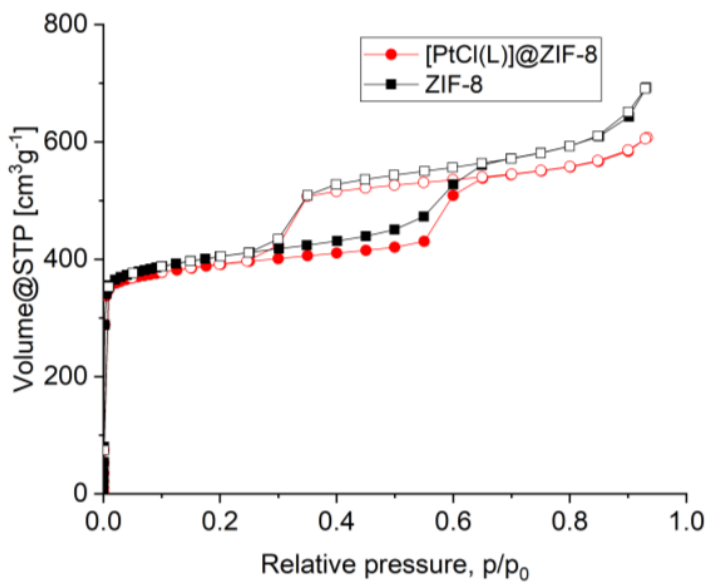

Figure S61. Ar-Sorption of [PtCI(L)]@ZIF-8 (red circles) and neat ZIF-8 (black squares). Filled symbols: adsorption, open symbols: desorption.

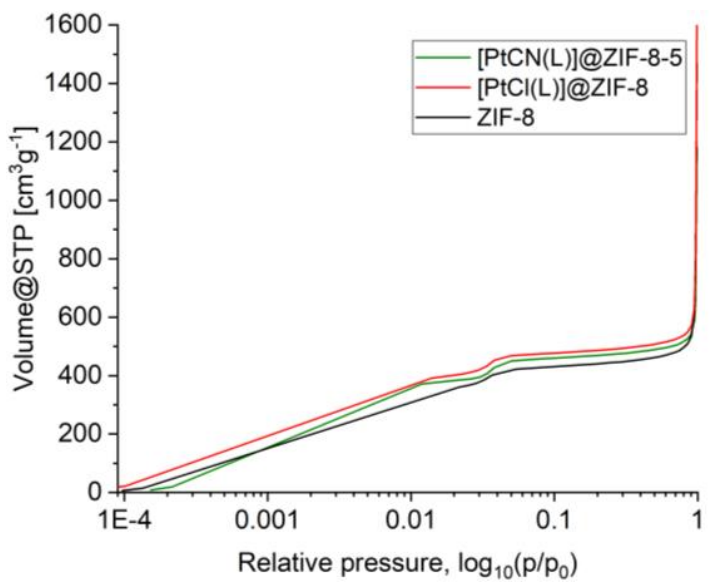

Figure S62. Logarithmic plot of the $\mathrm{N}_{2}$-adsorption of [PtCN(L)]@ZIF-8 (green), [PtCI(L)]@ZIF-8 (red) and ZIF-8 (black) to emphasize the two steps in the isotherm. 
The early step in $\mathrm{N}_{2}$ sorption is literature-known and referred to a structural change in the MOF, leading to higher uptakes. ${ }^{15}$ However, this step makes it complicate to determine a reliable BET-surface area. Düren et al. further investigated the step, resulting in very different BET-surfaces depending on whether the BET-equation was fit to before the step or in a broad range including the step. ${ }^{16}$ We also determined the BET-surface in two regions and also obtained two very different BET-surface areas for all samples.

Table S5. BET-surfaces determined for two pressure ranges, one bevor the adsorption step, the other including the adsorption step.

\begin{tabular}{|l|l|l|l|l|}
\hline \multicolumn{3}{|l|}{ before step $^{\mathrm{a}}$} & including step $^{\mathrm{b}}$ \\
\hline & C-constant & BET & C-constant & BET \\
\hline ZIF-8 & 1693 & 1405 & 336 & 1789 \\
\hline$[$ PtCN(L)]@ZIF-8 & 2579 & 1378 & 410 & 1757 \\
\hline$[$ PtCI(L)]@ZIF-8 & 682 & 1526 & 343 & 1682 \\
\hline
\end{tabular}

${ }^{a}$ Determined in a pressure range of $\mathrm{p} / \mathrm{p}_{0}=0.005-0.02 .{ }^{\mathrm{b}}$ Determined in a pressure range of $\mathrm{p} / \mathrm{p}_{0}=0.06-0.05$.

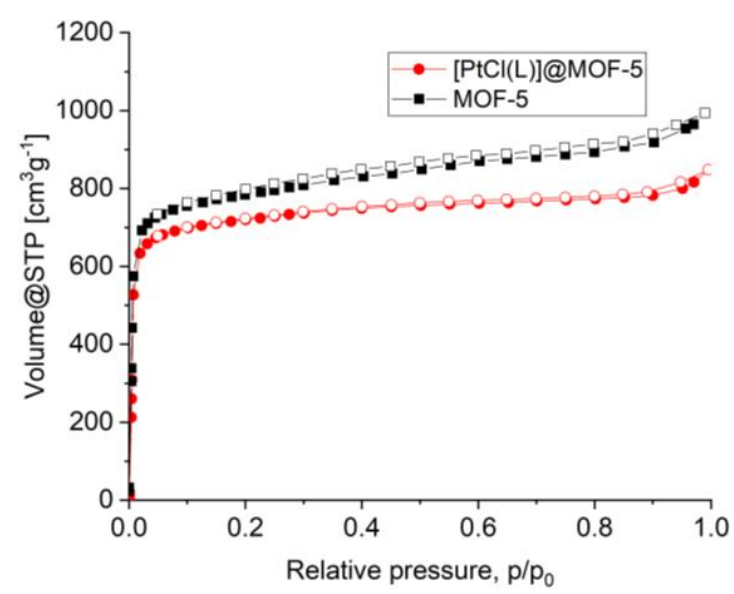

Figure S63. $\mathrm{N}_{2}$-Sorption of $[\mathrm{PtCl}(\mathrm{L})] @ M O F-5$ (red circles) and neat MOF-5 (black squares). Filled symbols: adsorption, open symbols: desorption.

Table S6. BET surface areas of the ZIF-8 composites and neat MOF.

\begin{tabular}{|l|l|l|l|l|}
\hline Sample & BET $\left[\mathrm{m}^{2} \mathrm{~g}^{-1}\right]$ & $\begin{array}{l}\text { maximum } \\
\text { uptakea } \\
{\left[\mathrm{cm}^{3} \mathrm{~g}^{-1}\right]}\end{array}$ & $\begin{array}{l}\text { micropore } \\
\text { volumeb } \\
{\left[\mathrm{cm}^{3} \mathrm{~g}^{-1}\right]}\end{array}$ & $\begin{array}{l}\text { total pore } \\
\text { volume } \\
{\left[\mathrm{cm}^{3} \mathrm{~g}^{-1}\right]}\end{array}$ \\
\hline$[$ PtCN(L)]@ZIF-8-5* & 1757 & 443 & 0.6 & 0.73 \\
\hline [PtCl(L)]@ZIF-8 & 1682 & 421 & 0.6 & 0.72 \\
\hline ZIF-8 & $\begin{array}{l}1789 \\
(\mathrm{Lit} 9962- \\
1800)^{17-20}\end{array}$ & 441 & 0.6 & 0.74 \\
\hline
\end{tabular}

* "-5" in ZIF-8-5 indicates the amount of Pt complex in $\mathrm{mg}$, which was used in the composite synthesis. ${ }^{a}$ Determined at $\mathrm{p} / \mathrm{p}_{0}=0.4$. ${ }^{\mathrm{b}}$ Determined at a $\mathrm{p} / \mathrm{p}_{0}=0.1-0.2$ for pores $<15 \mathrm{~nm} ;{ }^{\mathrm{c}}$ Determined at a $\mathrm{p} / \mathrm{p}_{0}=0.85$ for pores $<15 \mathrm{~nm}$. 


\section{Schematic representation of the encapsulation in ZIF-8}
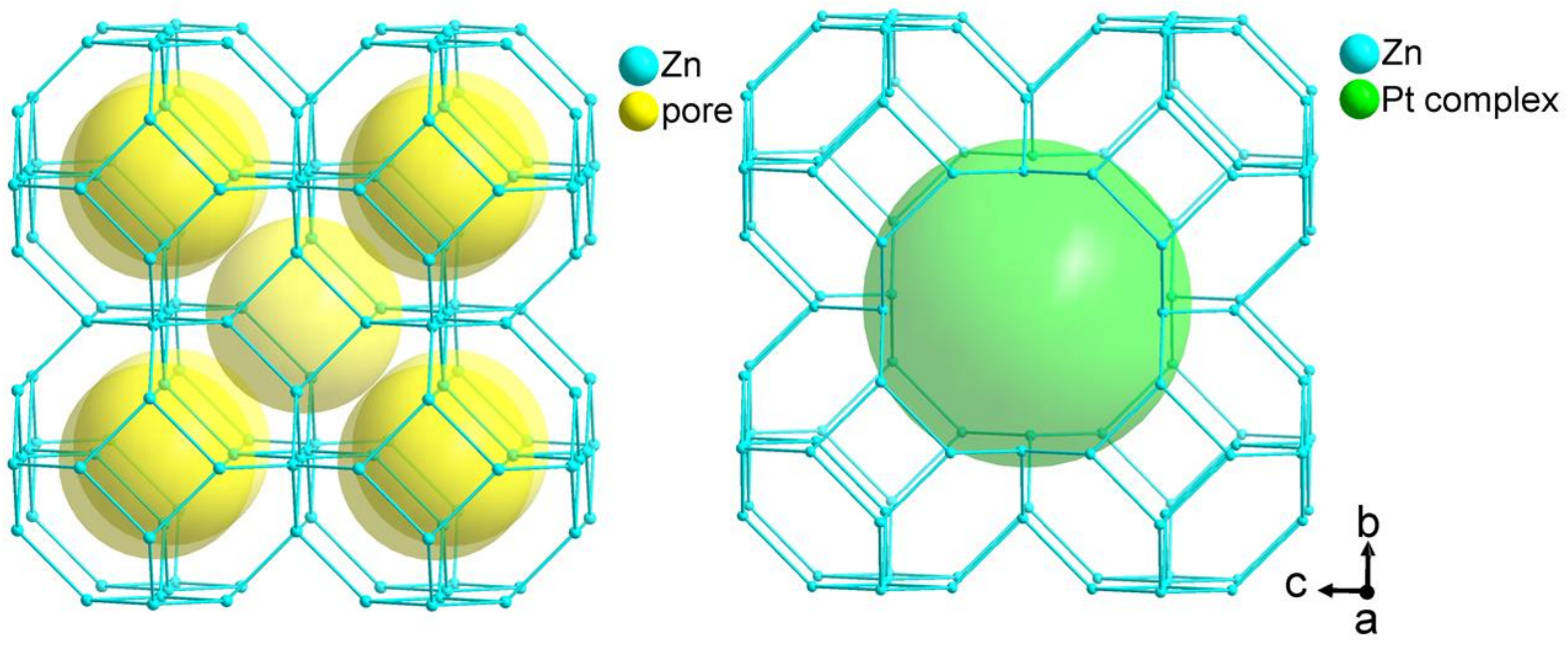

Figure S64. Schematic representation of the encapsulation of the Pt(II)-complex in ZIF-8. Left: Representation of the pores (yellow) in a defect-free ZIF-8 cage (turquoise); Right: Defective ZIF-8 structure with a "super pore" generated by the encapsulation of the $\mathrm{Pt}(\mathrm{II})$-complex (green). Note that the probable hydrodynamic radius of the $\mathrm{Pt}(\mathrm{II})$-complex is larger than the normally available pore size of ZIF-8.

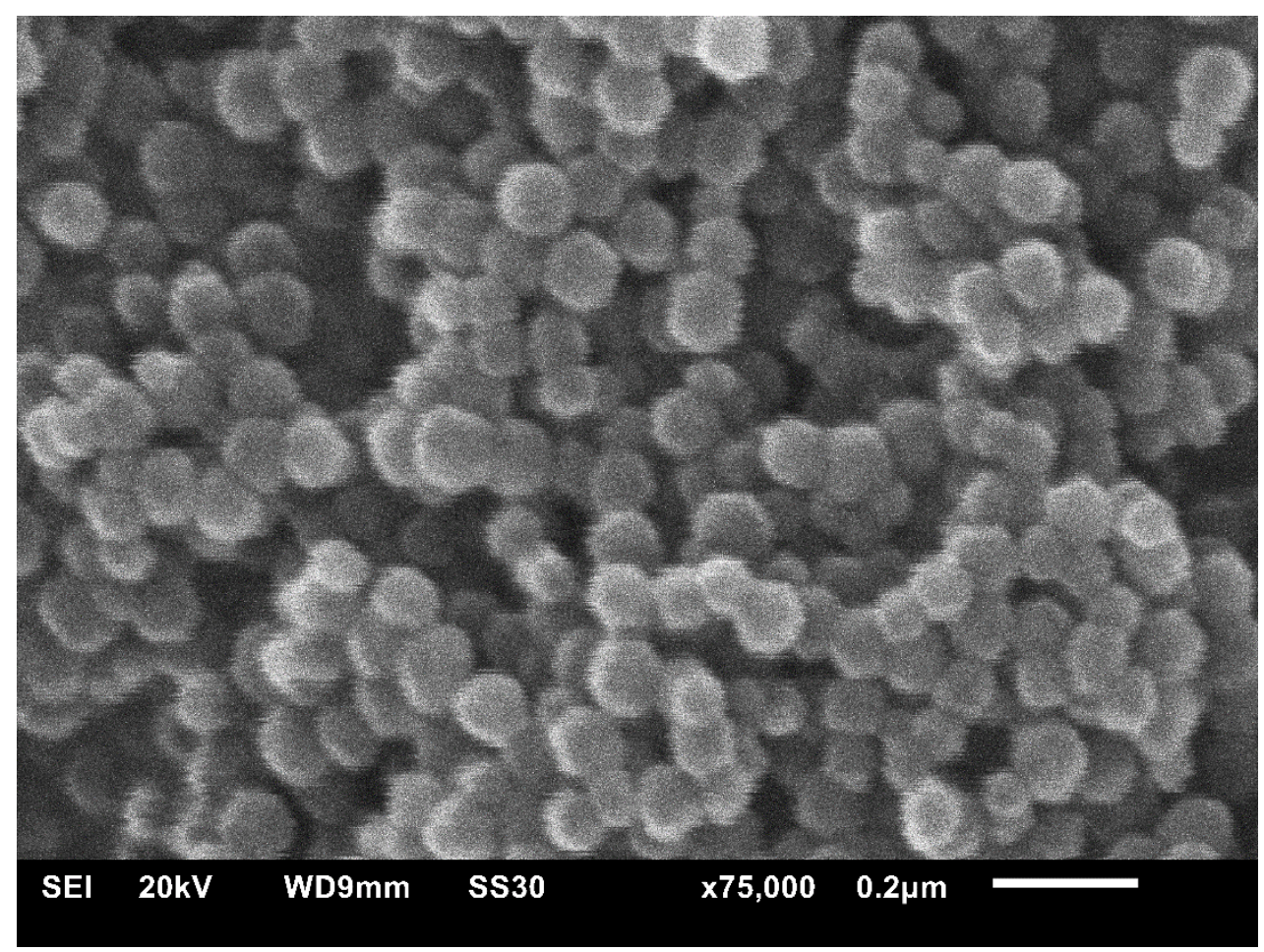

Figure S65. SEM image of [PtCl(L)]@ZIF-8. 


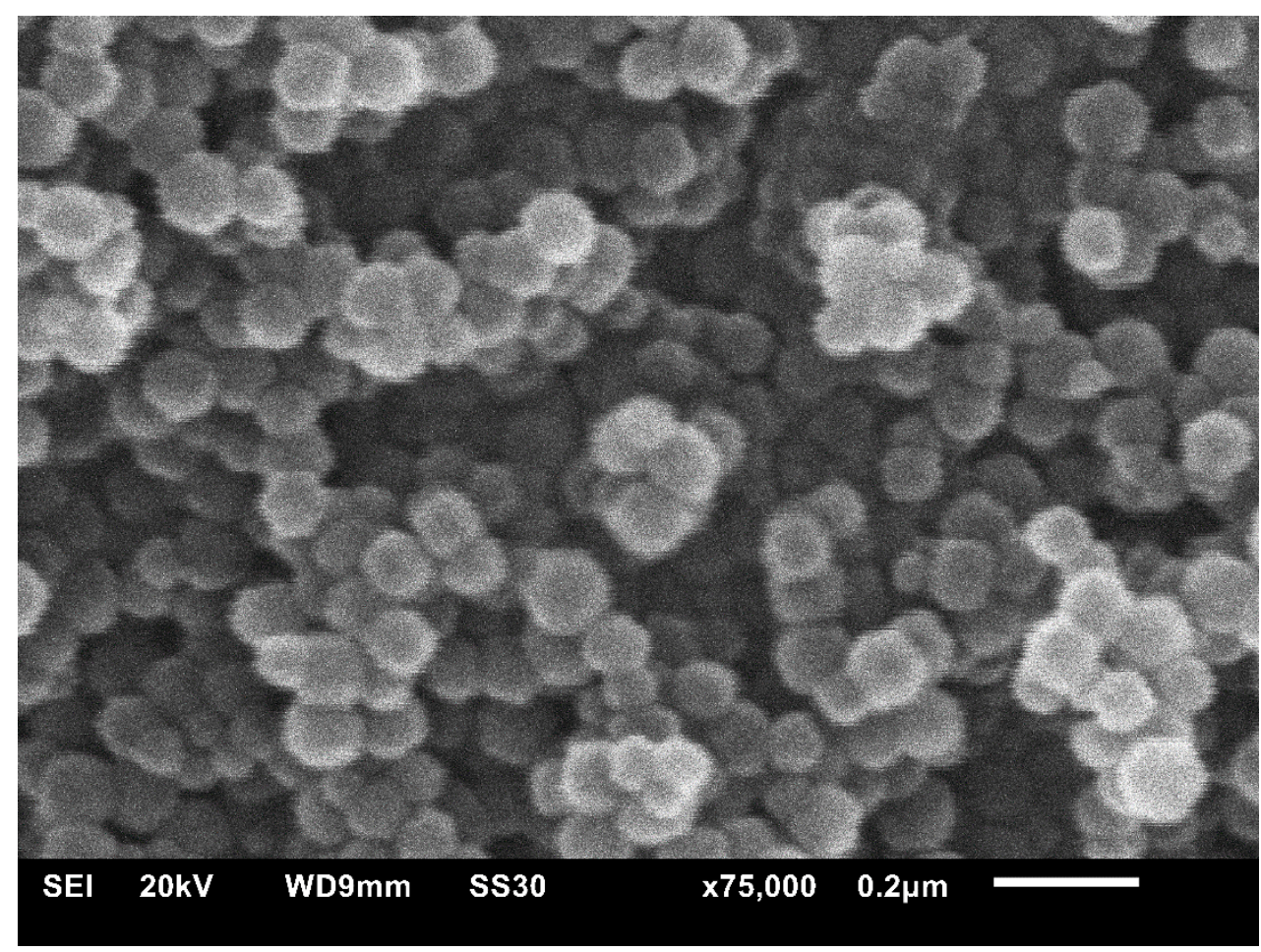

Figure S66. SEM image of neat ZIF-8.

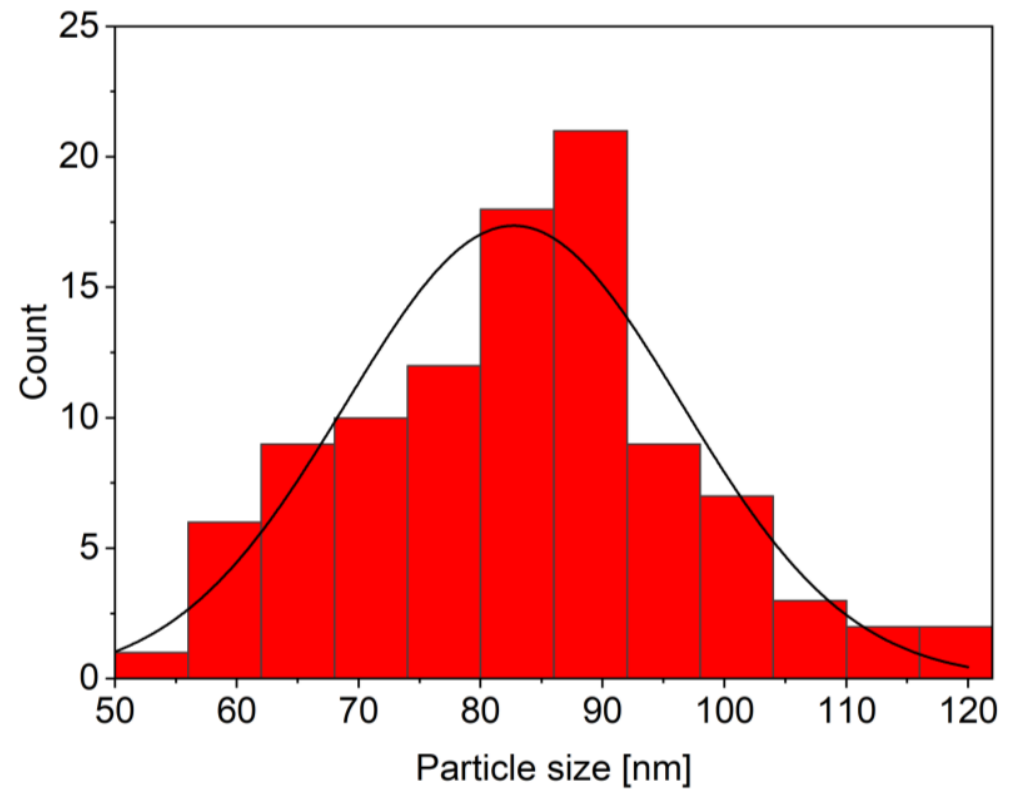

Figure S67. Particle size distribution histogram and normal distribution of $83 \pm 14$ for [PtCN(L)]@ZIF-8. 


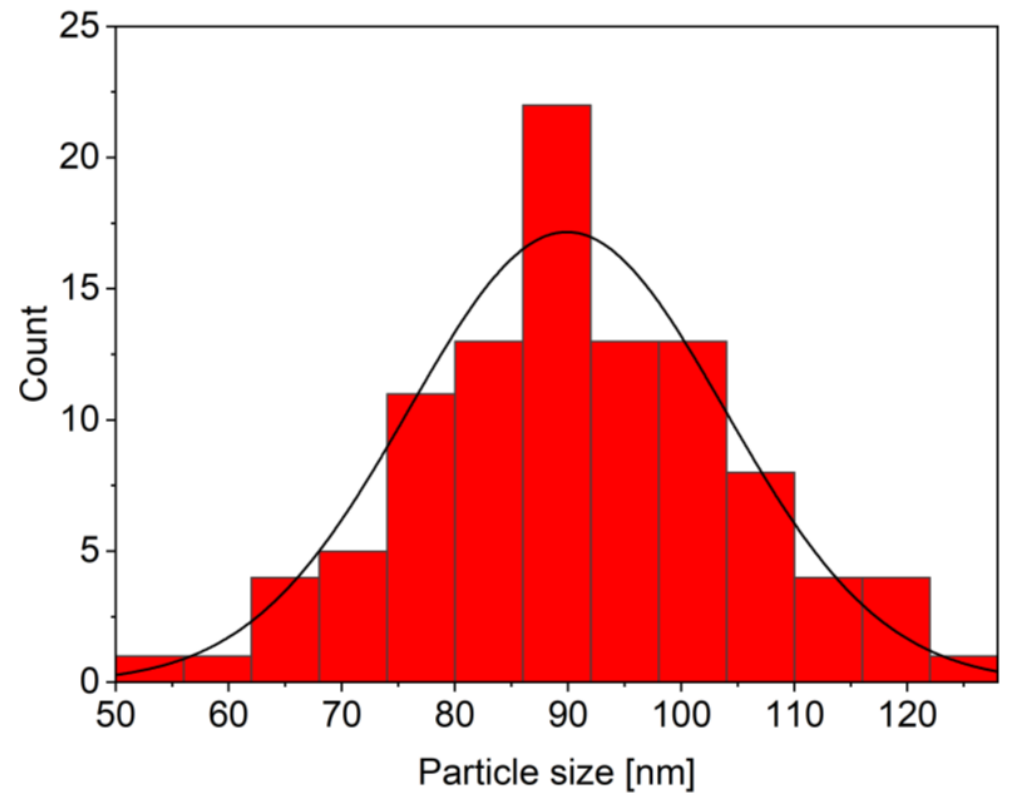

Figure S68. Particle size distribution histogram and normal distribution of $90 \pm 14$ for [PtCI(L)]@ZIF-8.

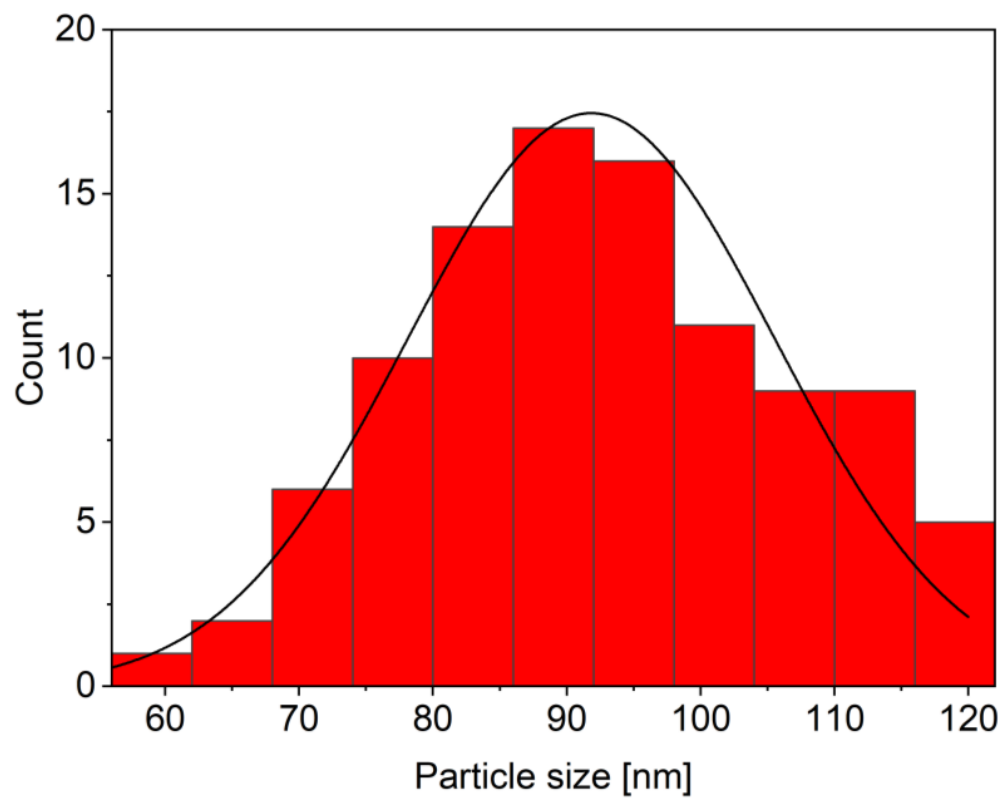

Figure S69. Particle size distribution histogram and normal distribution of $92 \pm 14$ for neat ZIF-8. 


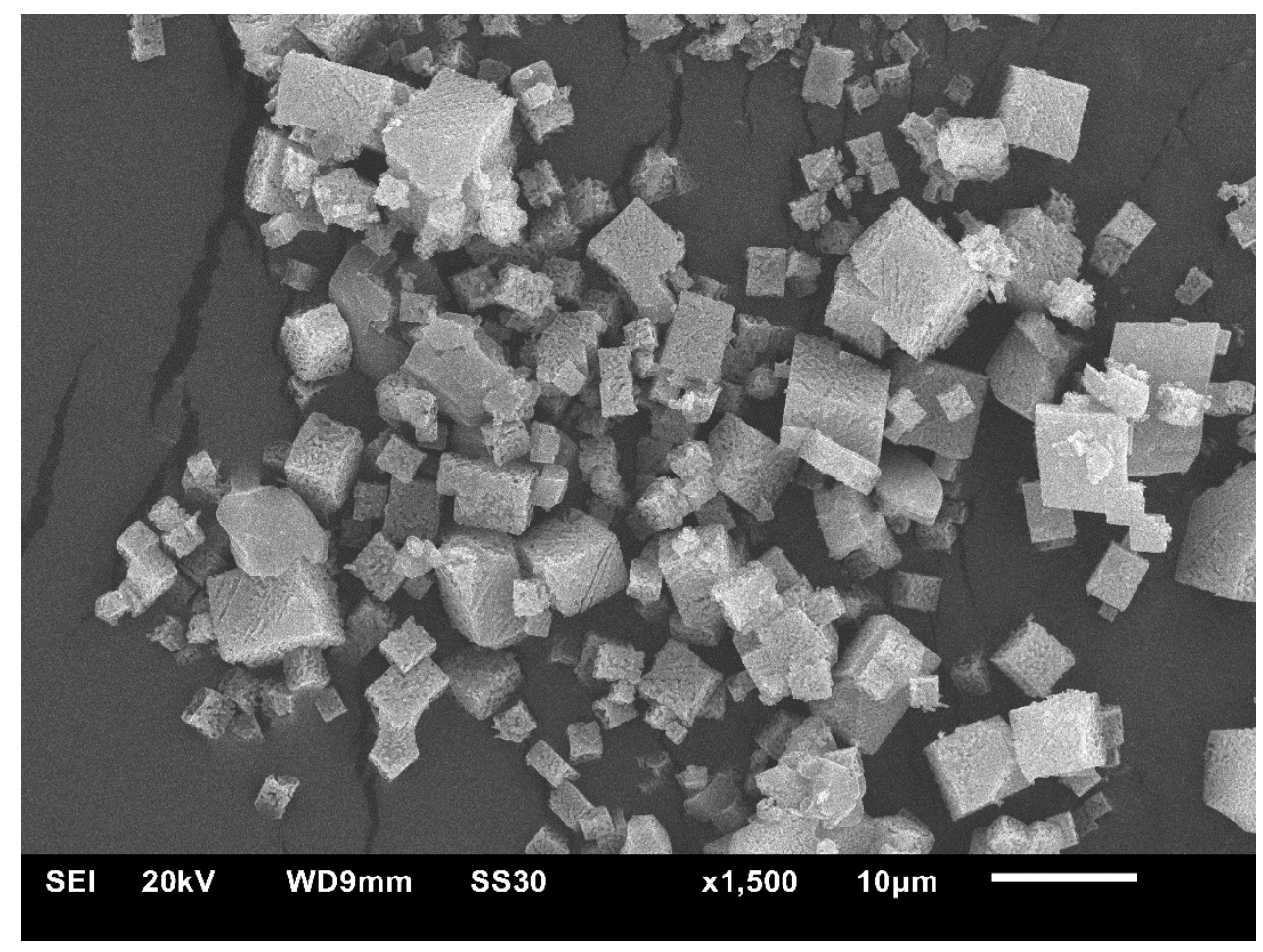

Figure S70. SEM image of [PtCl(L)]@MOF-5.

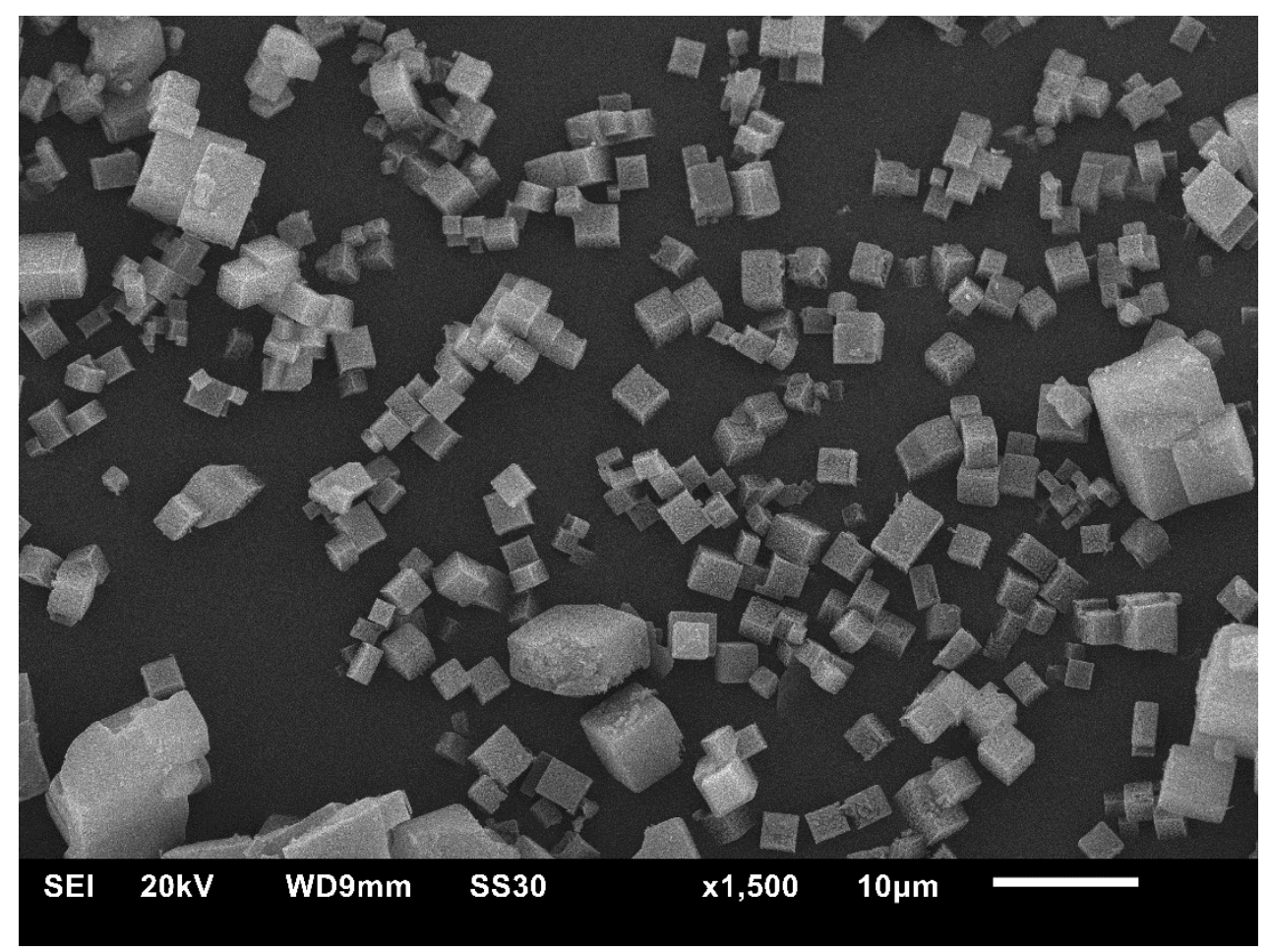

Figure S71. SEM image of neat MOF-5. 


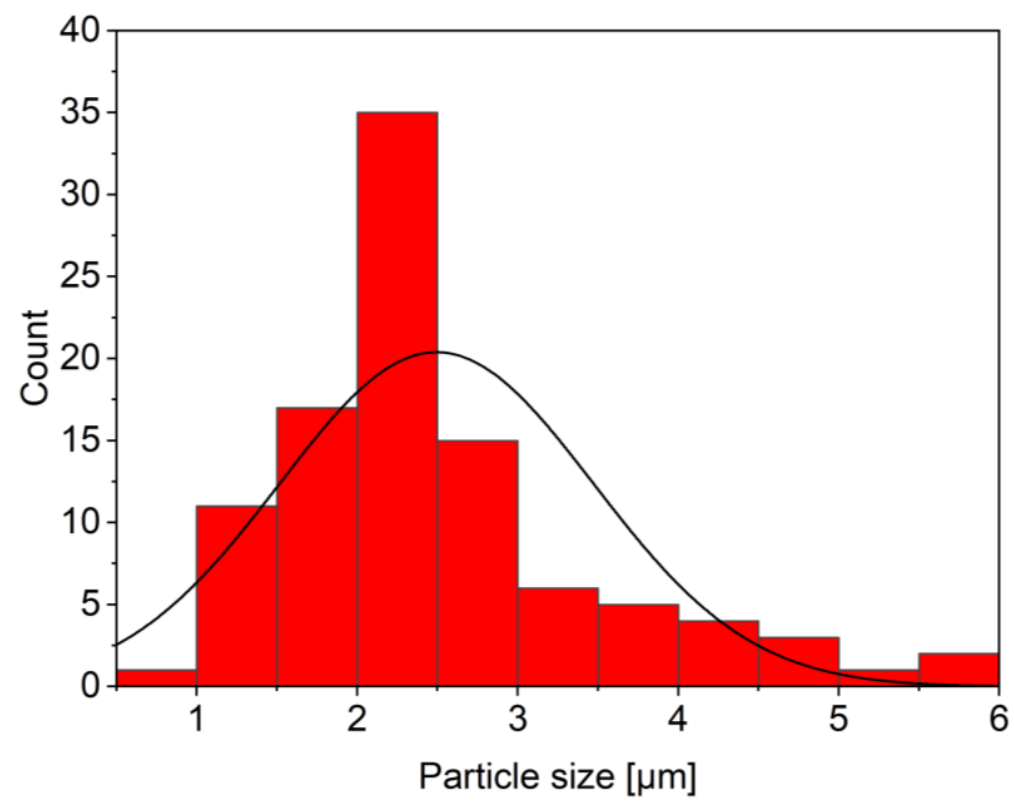

Figure S72. Particle size distribution histogram and normal distribution of $2 \pm 1 \mu \mathrm{m}$ for $[\mathrm{PtCN}(\mathrm{L})] @ M O F-5$.

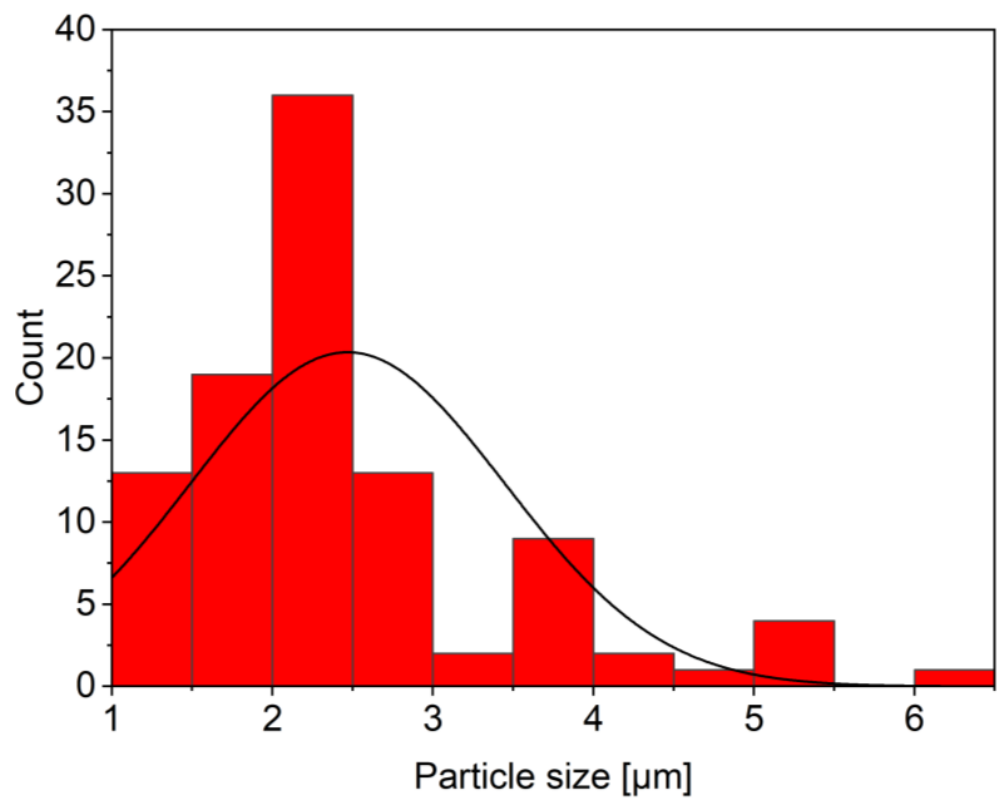

Figure S73. Particle size distribution histogram and normal distribution of $2 \pm 1 \mu \mathrm{m}$ for $[\mathrm{PtCl}(\mathrm{L})] @ M O F-5$. 


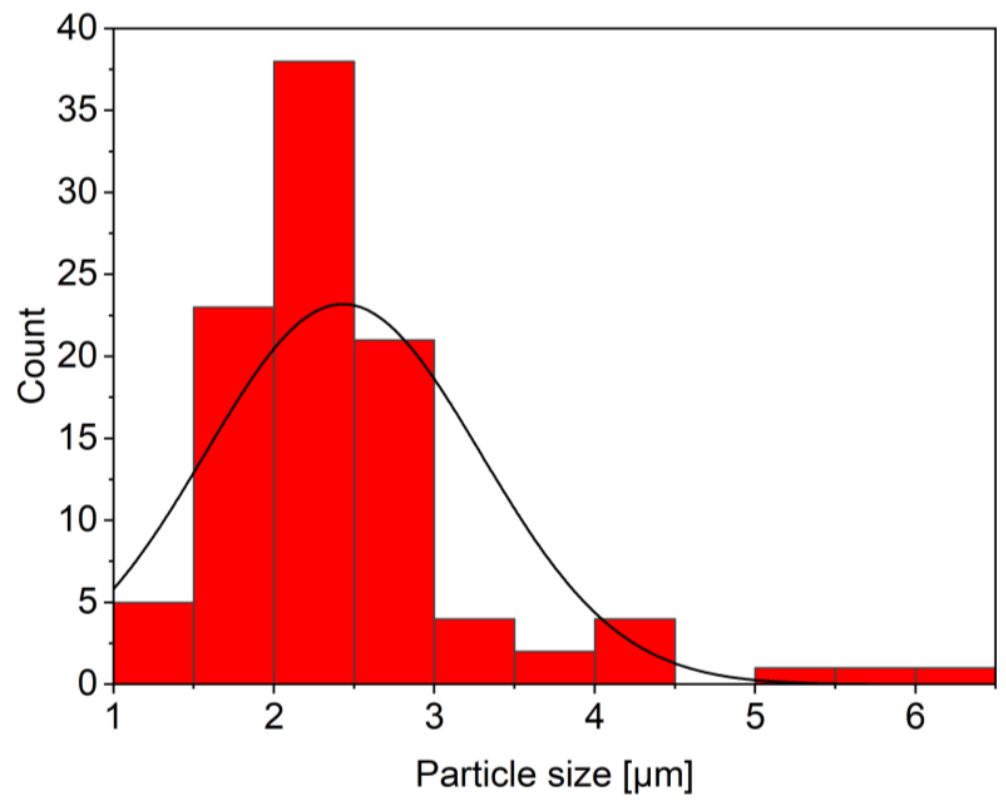

Figure S74. Particle size distribution histogram and normal distribution of $2 \pm 1 \mu \mathrm{m}$ for neat MOF-5. 


\section{Section S8: Atomic absorption spectroscopy of [PtCN(L)]@MOF and [PtCl(L)]@MOF}

Table S7. Platinum and zinc amounts from AAS in ZIF-8 composites and neat MOF.

\begin{tabular}{|c|c|c|c|c|c|c|c|c|c|c|}
\hline Sample * & $\begin{array}{l}\text { Sample } \\
\text { mass } \\
\text { [mg] }\end{array}$ & $\begin{array}{l}\text { V(Sample) } \\
\text { for GFAAS } \\
{[\mathrm{mL}]^{\mathrm{a}, \mathrm{b}}}\end{array}$ & $\begin{array}{l}\text { V(Sample) } \\
\text { for FAAS } \\
{[\mathrm{mL}]^{\mathrm{a}}}\end{array}$ & $\begin{array}{l}\mathrm{c}(\mathrm{Pt}) \text { in } \\
\text { GFAAS } \\
\text { solution } \\
{\left[\mu \mathrm{gL}^{-1}\right]^{\mathrm{c}}}\end{array}$ & $\begin{array}{l}c(Z n) \text { in } \\
\text { FAAS } \\
\text { solution }{ }^{c} \\
{\left[\mu \mathrm{gL}^{-1}\right]^{c}}\end{array}$ & $\begin{array}{l}\mathrm{m}(\mathrm{Pt}) \\
{[\mu \mathrm{g}]} \\
\text { and } \\
\text { range }\end{array}$ & $\begin{array}{l}\mathrm{m}(\mathrm{Zn}) \\
{[\mu \mathrm{g}]} \\
\text { and } \\
\text { range }\end{array}$ & $\begin{array}{l}\text { mass\% } \\
\text { Pt- } \\
\text { complex } \\
\text { and } \\
\text { range }^{\mathrm{d}, \mathrm{e}}\end{array}$ & $\begin{array}{l}\text { mass\% } \\
\text { Zn in } \\
\text { sample } \\
\text { and } \\
\text { range e,f }\end{array}$ & $\begin{array}{l}\text { molar } \\
\text { ratio } \\
\mathrm{Pt}: \mathrm{Zn}\end{array}$ \\
\hline \multirow{2}{*}{ ZIF-8g } & 1.31 & 2 & 1000 & $0^{\mathrm{h}}$ & $380 \pm 2$ & 0 & $380 \pm 2$ & 0 & $\begin{array}{l}29.0 \pm \\
0.4\end{array}$ & n.a. ${ }^{i}$ \\
\hline & 1.3 & 2 & 1000 & $0^{\mathrm{h}}$ & $368 \pm 1$ & 0 & $368 \pm 1$ & 0 & $\begin{array}{l}28.3 \pm \\
0.3\end{array}$ & n.a. ${ }^{i}$ \\
\hline \multirow{2}{*}{$\begin{array}{l}{[\mathrm{PtCN}(\mathrm{L})} \\
\text { ]@ZIF-8- } \\
1\end{array}$} & 1.29 & 2 & 1000 & $306 \pm 5$ & $\begin{array}{l}368.7 \pm \\
0.4\end{array}$ & $\begin{array}{l}0.61 \pm \\
0.01\end{array}$ & $\begin{array}{l}368.7 \pm \\
0.4\end{array}$ & $\begin{array}{l}0.126 \pm \\
0.003\end{array}$ & $\begin{array}{l}28.6 \pm \\
0.3\end{array}$ & $1: 1795$ \\
\hline & 0.93 & 2 & 1000 & $74 \pm 7$ & $\begin{array}{l}265.7 \pm \\
0.4\end{array}$ & $\begin{array}{l}0.15 \pm \\
0.01\end{array}$ & $\begin{array}{l}265.7 \pm \\
0.4\end{array}$ & $\begin{array}{l}0.042 \pm \\
0.004\end{array}$ & $\begin{array}{l}28.6 \pm \\
0.4\end{array}$ & $1: 5337$ \\
\hline \multirow{2}{*}{$\begin{array}{l}{[\mathrm{PtCN}(\mathrm{L})} \\
\text { ]@ZIF-8- } \\
2\end{array}$} & 1.19 & 2 & 1000 & $616 \pm 12$ & $307 \pm 2$ & $\begin{array}{l}1.23 \pm \\
0.02\end{array}$ & $307 \pm 2$ & $\begin{array}{l}0.27 \pm \\
0.01\end{array}$ & $\begin{array}{l}25.8 \pm \\
0.4\end{array}$ & $1: 744$ \\
\hline & 0.95 & 2 & 1000 & $200 \pm 13$ & $274 \pm 1$ & $\begin{array}{l}0.40 \pm \\
0.3\end{array}$ & $274 \pm 1$ & $\begin{array}{l}0.11 \pm \\
0.01\end{array}$ & $\begin{array}{l}28.8 \pm \\
0.4\end{array}$ & $1: 2043$ \\
\hline \multirow{2}{*}{$\begin{array}{l}\text { [PtCN(L) } \\
\text { ]@ZIF-8- } \\
5\end{array}$} & 0.83 & 8 & 1000 & $785 \pm 14$ & $\begin{array}{l}194.7 \pm \\
0.4\end{array}$ & $\begin{array}{l}6.3 \pm \\
0.1\end{array}$ & $\begin{array}{l}194.7 \pm \\
0.4\end{array}$ & $2.0 \pm 0.1$ & $\begin{array}{l}23.5 \pm \\
0.3\end{array}$ & $1: 92$ \\
\hline & 1.19 & 16 & 1000 & $646 \pm 17$ & $352 \pm 2$ & $\begin{array}{l}10.3 \pm \\
0.3\end{array}$ & $352 \pm 2$ & $2.3 \pm 0.1$ & $\begin{array}{l}29.5 \pm \\
0.4\end{array}$ & $1: 101$ \\
\hline \multirow{2}{*}{$\begin{array}{l}{[\mathrm{PtCN}(\mathrm{L})} \\
] @ \mathrm{ZIF}-8- \\
10\end{array}$} & 1.18 & 16 & 1000 & $810 \pm 20$ & $298 \pm 1$ & $\begin{array}{l}12.9 \pm \\
0.4\end{array}$ & $298 \pm 1$ & $2.9 \pm 0.1$ & $\begin{array}{l}25.2 \pm \\
0.3\end{array}$ & $1: 68$ \\
\hline & 1.13 & 16 & 1000 & $720 \pm 40$ & $\begin{array}{l}338.3 \pm \\
0.4\end{array}$ & $\begin{array}{l}11.5 \pm \\
0.6\end{array}$ & $\begin{array}{l}338.3 \pm \\
0.4\end{array}$ & $2.7 \pm 0.1$ & $\begin{array}{l}29.9 \pm \\
0.3\end{array}$ & $1: 88$ \\
\hline \multirow{2}{*}{$\begin{array}{l}{[\mathrm{PtCl}(\mathrm{L})]} \\
@ \mathrm{ZIF}-8 \\
(5 \mathrm{mg})\end{array}$} & 1.05 & 8 & 1000 & $19 \pm 9$ & $\begin{array}{l}303.5 \pm \\
0.5\end{array}$ & $\begin{array}{l}0.15 \pm \\
0.07\end{array}$ & $\begin{array}{l}303.5 \pm \\
0.5\end{array}$ & $\begin{array}{l}0.08 \pm \\
0.05\end{array}$ & $\begin{array}{l}27.8 \pm \\
0.9\end{array}$ & $1: 2899$ \\
\hline & 0.93 & 2 & 1000 & $57 \pm 5$ & $276 \pm 1$ & $\begin{array}{l}0.11 \pm \\
0.01\end{array}$ & $276 \pm 1$ & $\begin{array}{l}0.033 \pm \\
0.003\end{array}$ & $\begin{array}{l}29.7 \pm \\
0.4\end{array}$ & $1: 7238$ \\
\hline
\end{tabular}

* "-1" to "-10" in ZIF-8-1, ZIF-8-10 etc. indicate the amount of Pt complex in mg (i.e. $1 \mathrm{mg}, 10$ $\mathrm{mg}$ ), which was used in the composite synthesis. ${ }^{\text {a }}$ olume in which the sample mass was dissolved. ${ }^{b}$ For each measurement $16 \mu \mathrm{L}$ of this solution was dispensed in the furnace. ${ }^{c}$ For all samples two independent measurements with three replicates each were performed. 'Based on the molar mass of the corresponding complex ([PtCN(L)], $M=515.00 \mathrm{~g} / \mathrm{mol}$ with $37.88 \mathrm{wt} \% \mathrm{Pt}$ ) or [PtCl(L)], $M=524.04 \mathrm{~g} / \mathrm{mol}$ with $37.23 \mathrm{wt} \% \mathrm{Pt}$ ) and mass of the composite. eDeviation was estimated by taking the deviation of the used balance $(\mathrm{d}=0.01 \mathrm{mg})$ into

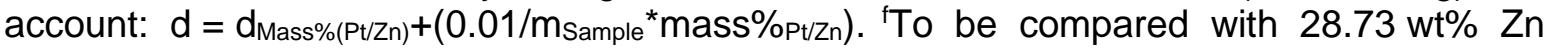
based on the formula mass of ZIF-8 ([Zn(Mim) $\left.\left.)_{2}\right], \mathrm{C}_{8} \mathrm{H}_{10} \mathrm{~N}_{4} \mathrm{Zn}, M=227.58 \mathrm{~g} / \mathrm{mol}\right)$. ${ }^{9}$ The measured Pt-concentrations are significantly negative, indicating that the amount of platinum is either below detection limit or zero. To exclude negative matrix effects, $2 \%$ [PtCN(L)] and $98 \%$ ZIF-8 were mixed and measured. $\mathrm{m}(\mathrm{Pt})_{\text {espected }}=7.5 \mu \mathrm{g}, \mathrm{m}(\mathrm{Pt})_{\text {measured }}=7.6 \pm 0.1 \mu \mathrm{g}$. Therefore, the value for blind correction of the corresponding composites was set to $0 \mathrm{\mu gL}^{-1}$. hSlightly negative value which was set to 0 . ${ }^{i}$ Not applicable. 
Table S8. Platinum and zinc amounts from AAS in MOF-5 composites and neat MOF.

\begin{tabular}{|c|c|c|c|c|c|c|c|c|c|c|}
\hline & $\begin{array}{l}\text { Sample } \\
\text { mass } \\
{[\mathrm{mg}]}\end{array}$ & $\begin{array}{l}\text { V(Sample) } \\
\text { GFAAS } \\
{[\mathrm{mL}]^{\mathrm{a}, \mathrm{b}}}\end{array}$ & 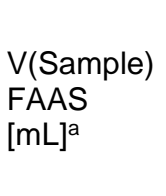 & $\begin{array}{l}c(P t) \text { in } \\
\text { AAS } \\
\text { solution } \\
{\left[\mu \mathrm{gL}^{-1}\right]^{a}}\end{array}$ & $\begin{array}{l}c(Z n) \text { in } \\
\text { FAAS } \\
\text { solution } \\
{\left[\mu \mathrm{gL}^{-1}\right]}\end{array}$ & $\begin{array}{l}\mathrm{m}(\mathrm{Pt}) \\
{[\mu \mathrm{g}]} \\
\text { and } \\
\text { range }\end{array}$ & $\begin{array}{l}\mathrm{m}(\mathrm{Zn}) \\
{[\mu \mathrm{g}]} \\
\text { and } \\
\text { range }\end{array}$ & $\begin{array}{l}\text { Mass\% } \\
\text { Pt- } \\
\text { complex } \\
\text { and } \\
\text { range }\end{array}$ & $\begin{array}{l}\text { mass\% } \\
\text { Zn in } \\
\text { sample } \\
\text { and } \\
\text { range }^{e, f}\end{array}$ & $\begin{array}{l}\text { molar ratio } \\
\mathrm{Pt}: \mathrm{Zn}\end{array}$ \\
\hline \multirow{2}{*}{$\begin{array}{l}\text { MOF-5 } \\
\text { (single } \\
\text { crystal) }\end{array}$} & 0.69 & 2 & 1000 & $0^{h}$ & $210 \pm 1$ & 0 & $210 \pm 1$ & 0 & $\begin{array}{l}30.4 \pm \\
0.5\end{array}$ & n.a. ${ }^{i}$ \\
\hline & 0.71 & 2 & 1000 & $0^{\mathrm{h}}$ & $\begin{array}{l}256.7 \pm \\
0.4\end{array}$ & 0 & $\begin{array}{l}256.7 \pm \\
0.4\end{array}$ & 0 & $\begin{array}{l}29.7 \pm \\
0.6\end{array}$ & n.a. ${ }^{i}$ \\
\hline \multirow{2}{*}{$\begin{array}{l}\text { MOF-5 } \\
\text { (powder) }\end{array}$} & 1.02 & 2 & 1000 & $\begin{array}{l}13.05 \pm \\
0.5\end{array}$ & $342 \pm 2$ & $\begin{array}{l}0.026 \pm \\
0.001\end{array}$ & $342 \pm 2$ & $\begin{array}{l}0.007 \pm \\
0.001\end{array}$ & $\begin{array}{l}33.6 \pm \\
0.5\end{array}$ & n.a. ${ }^{i}$ \\
\hline & 0.97 & 2 & 1000 & $\begin{array}{l}2.5 \pm \\
0.3\end{array}$ & $297 \pm 1$ & $\begin{array}{l}0.0050 \\
\pm 0.007\end{array}$ & $297 \pm 1$ & $\begin{array}{l}0.0014 \pm \\
0.0003\end{array}$ & $\begin{array}{l}30.6 \pm \\
0.4\end{array}$ & n.a. ${ }^{i}$ \\
\hline \multirow{2}{*}{$\begin{array}{l}{[\mathrm{PtCN}(\mathrm{L})] @} \\
\text { MOF-5 } \\
\text { (single } \\
\text { crystal) }\end{array}$} & 0.78 & 2 & 1000 & $\begin{array}{l}565 \pm \\
10\end{array}$ & $\begin{array}{l}256.7 \pm \\
0.4\end{array}$ & $\begin{array}{l}1.13 \pm \\
0.2\end{array}$ & $\begin{array}{l}256.7 \pm \\
0.4\end{array}$ & $\begin{array}{l}0.37 \pm \\
0.05\end{array}$ & $\begin{array}{l}31.3 \pm \\
0.4\end{array}$ & $1: 677$ \\
\hline & 0.58 & 2 & 1000 & $423 \pm 2$ & $\begin{array}{l}181.3 \pm \\
0.4\end{array}$ & $\begin{array}{l}0.847 \pm \\
0.005\end{array}$ & $\begin{array}{l}181.3 \pm \\
0.4\end{array}$ & $\begin{array}{l}0.37 \pm \\
0.06\end{array}$ & $\begin{array}{l}30.2 \pm \\
0.6\end{array}$ & $1: 638$ \\
\hline \multirow{2}{*}{$\begin{array}{l}{[\mathrm{PtCN}(\mathrm{L})] @} \\
\text { MOF-5 } \\
\text { (powder)j }^{\mathrm{j}}\end{array}$} & 0.67 & 16 & 1000 & $543 \pm 9$ & $226 \pm 1$ & $\begin{array}{l}8.7 \pm \\
0.1\end{array}$ & $226 \pm 1$ & $3.4 \pm 0.6$ & $\begin{array}{l}33.8 \pm \\
0.6\end{array}$ & $1: 77$ \\
\hline & 0.71 & 16 & 1000 & $612 \pm 3$ & $239 \pm 1$ & $\begin{array}{l}9.78 \pm \\
0.05\end{array}$ & $239 \pm 1$ & $3.7 \pm 0.5$ & $\begin{array}{l}33.6 \pm \\
0.6\end{array}$ & $1: 72$ \\
\hline \multirow{2}{*}{$\begin{array}{l}\text { [PtCl(L)]@M } \\
\text { OF-5 (single } \\
\text { crystal) }\end{array}$} & 1.10 & 1 & 1000 & $13 \pm 2$ & $\begin{array}{l}340.3 \pm \\
0.4\end{array}$ & $\begin{array}{l}0.013 \pm \\
0.002\end{array}$ & $\begin{array}{l}340.3 \pm \\
0.4\end{array}$ & $\begin{array}{l}0.003 \pm \\
0.001\end{array}$ & $\begin{array}{l}30.9 \pm \\
0.3\end{array}$ & n.a. ${ }^{i}$ \\
\hline & 0.91 & 1 & 1000 & $5 \pm 1$ & $266 \pm 2$ & $\begin{array}{l}0.005 \pm \\
0.001\end{array}$ & $266 \pm 2$ & $\begin{array}{l}0.0015 \pm \\
0.0004\end{array}$ & $\begin{array}{l}29.2 \pm \\
0.5\end{array}$ & n.a. ${ }^{i}$ \\
\hline \multirow{2}{*}{$\begin{array}{l}{[\mathrm{PtCl}(\mathrm{L})] @ M} \\
\text { OF-5 } \\
\text { (powder)j }^{\mathrm{j}}\end{array}$} & 1.10 & 2 & 1000 & $620 \pm 5$ & $\begin{array}{l}364.3 \pm \\
0.4\end{array}$ & $\begin{array}{l}1.23 \pm \\
0.01\end{array}$ & $\begin{array}{l}364.3 \pm \\
0.4\end{array}$ & $\begin{array}{l}0.30 \pm \\
0.03\end{array}$ & $\begin{array}{l}33.1 \pm \\
0.3\end{array}$ & $1: 875$ \\
\hline & 0.96 & 2 & 1000 & $341 \pm 1$ & $317 \pm 1$ & $\begin{array}{l}0.666 \pm \\
0.001\end{array}$ & $317 \pm 1$ & $\begin{array}{l}0.19 \pm \\
0.02\end{array}$ & $\begin{array}{l}30.9 \\
\pm 0.5\end{array}$ & $1: 1386$ \\
\hline
\end{tabular}

aVolume in which the sample mass was dissolved. bFor each measurement, $16 \mu \mathrm{L}$ of this solution was dispensed in the furnace. ${ }^{c}$ For all samples two independent measurements with three replicates each were performed. ${ }^{\mathrm{d} B a s e d}$ on the molar mass of the corresponding complex ([PtCN(L)], $M=515.00 \mathrm{~g} / \mathrm{mol}$ with $37.88 \mathrm{wt} \% \mathrm{Pt}$ ) or $[\mathrm{PtCl}(\mathrm{L})], M=524.04 \mathrm{~g} / \mathrm{mol}$ with $37.23 \mathrm{wt} \% \mathrm{Pt})$ and mass of the composite. ${ }^{e}$ Deviation was estimated by taking the deviation of the used balance $(\mathrm{d}=0.01 \mathrm{mg})$ into account: $\mathrm{d}=\mathrm{d}$ Mass\%(Pt/Zn)+(0.01/msample ${ }^{*}$ mass\% $\left.\% \mathrm{Pt} / \mathrm{Zn}\right) .{ }^{\mathrm{f}}$ To be compared with $33.97 \mathrm{wt} \% \mathrm{Zn}$ based

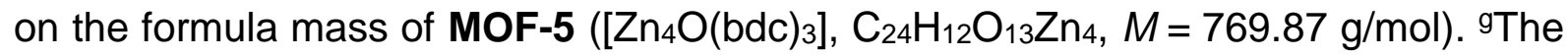
measured Pt-concentrations are slightly negative, indicating that the amount of platinum is either below detection limit or zero. Therefore, the value for blind correction of the corresponding composites was set to $0 \mathrm{\mu gL}^{-1}$. 'hSlightly negative value which was set to $0 .{ }^{i}$ Not applicable. ${ }^{j}$ corrected for the blind value for MOF-5 powder. 
Section S9: Confocal laser scanning microscopy of [PtCN(L)]@MOF-5, [PtCl(L)]@MOF-5 and MOF-5 (single crystals)

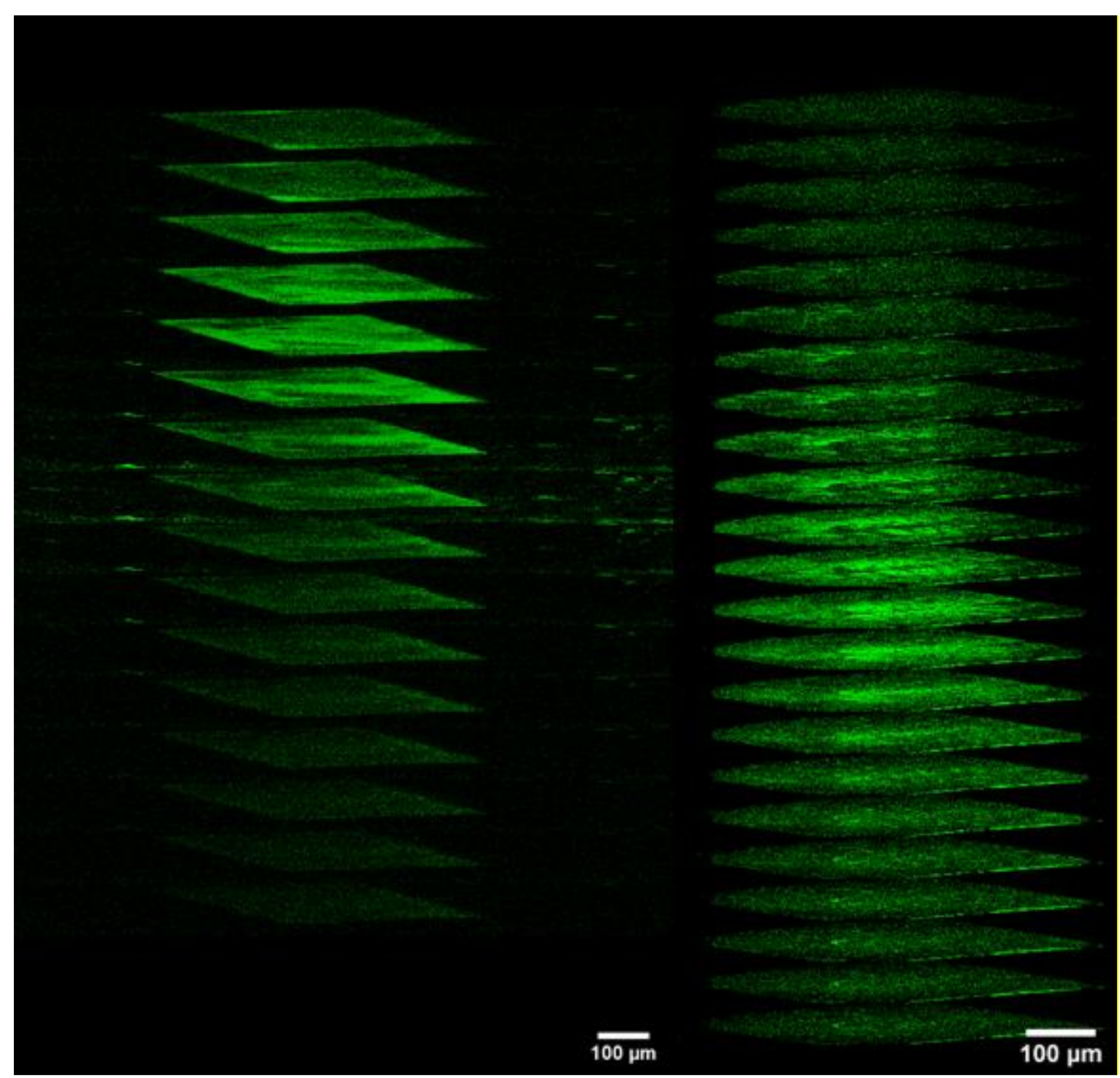

Figure S75. CLSM image of [PtCI(L)]@MOF-5 (left) and neat MOF-5 (right). For the laser power of $15 \%$ for [PtCl(L)]@MOF-5 (left) the visible fluorescence originates significantly from MOF-5, to be compared with the right image. $\lambda_{\mathrm{exc}}=405 \mathrm{~nm}, \lambda_{\mathrm{em}}=550 \mathrm{~nm}$. 


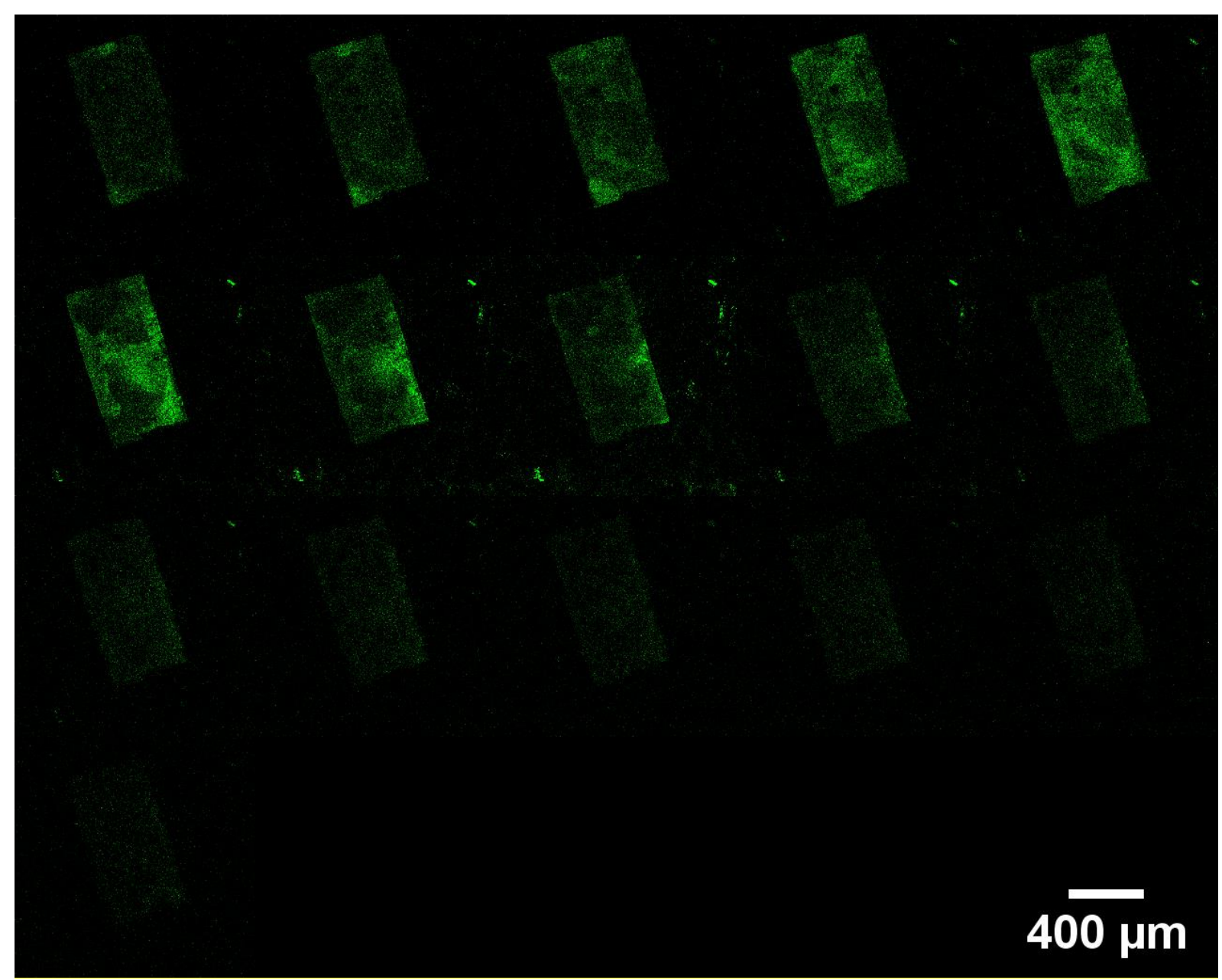

Figure S76. CLSM image of MOF-5. The crystal was scanned in z-direction in steps of $0.1 \mu \mathrm{m}$. The obtained images are shown from the top of the crystal (top left picture) to the middle of the crystal (bottom right picture). $\lambda_{\text {exc }}=405 \mathrm{~nm}$, $\lambda_{\mathrm{em}}=550 \mathrm{~nm}$. 


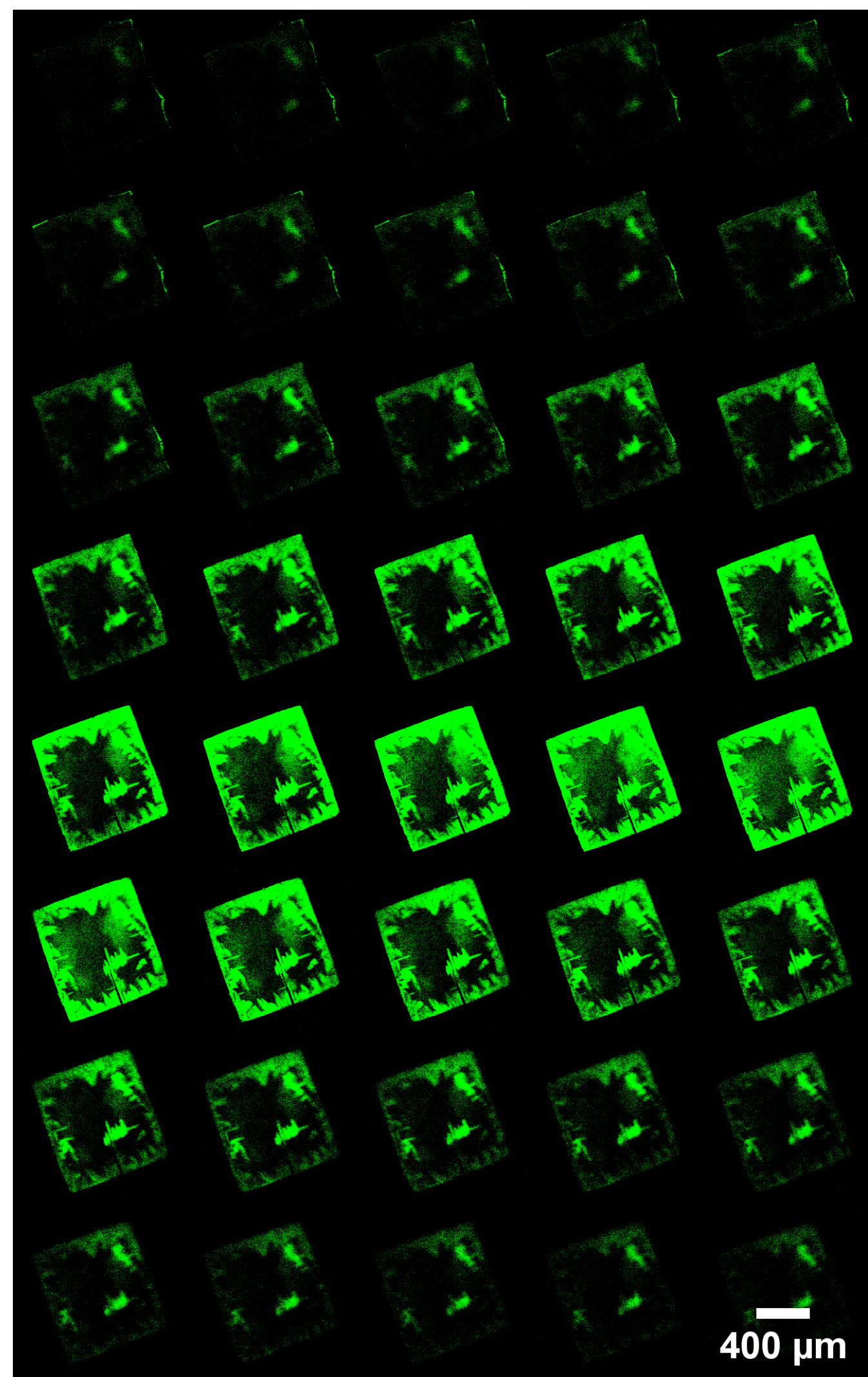

Figure S77. CLSM image of [PtCN(L)]@MOF-5. The crystal was scanned in z-direction in steps of $0.1 \mu \mathrm{m}$. The obtained images are shown from the top of the crystal (top left picture) to the middle of the crystal (bottom right picture) (cf. Fig. 7 in main manuscript for the stack view). $\lambda_{\mathrm{exc}}=405 \mathrm{~nm}, \lambda_{\mathrm{em}}=550 \mathrm{~nm}$. 


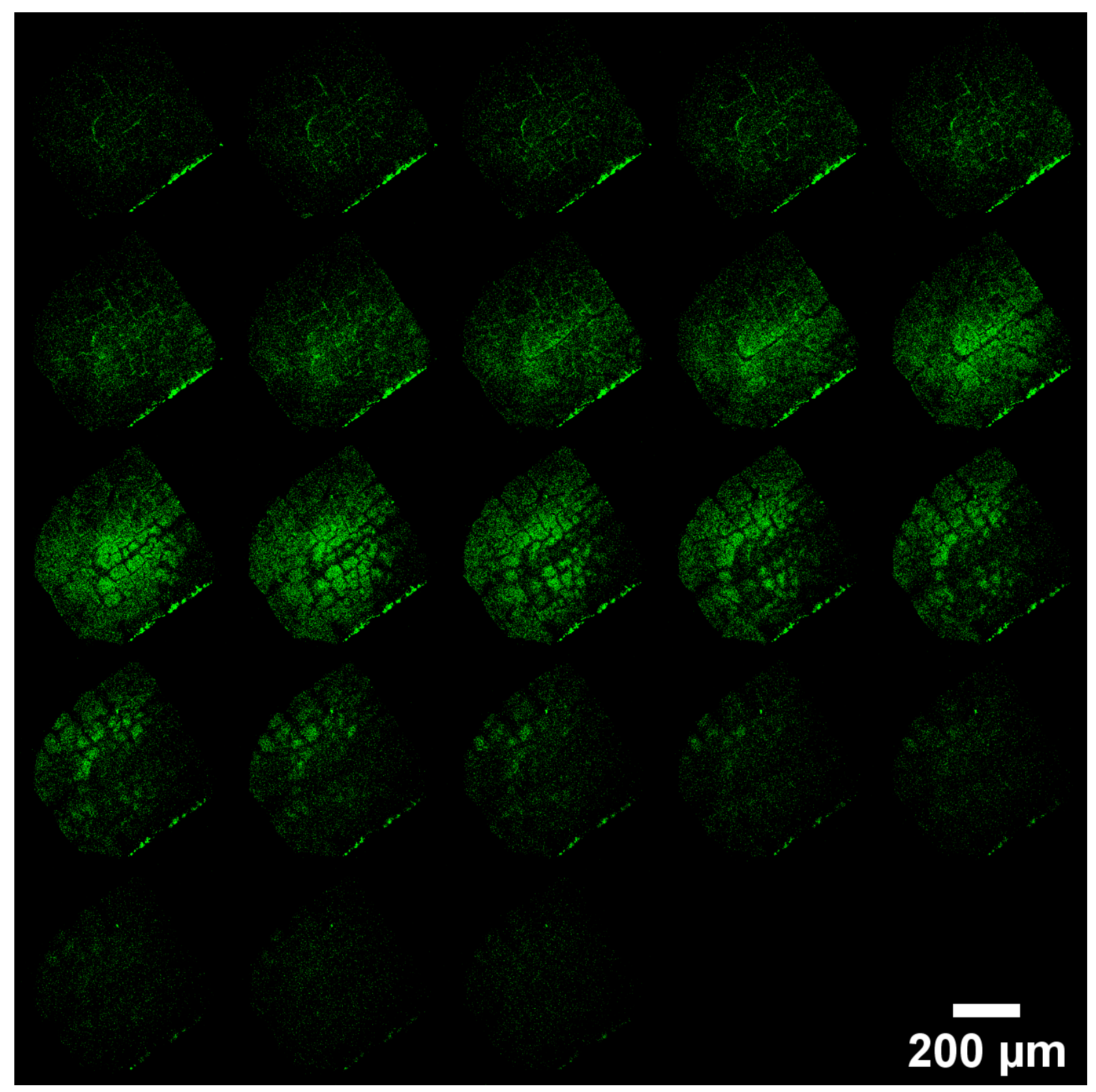

Figure S78. CLSM image of $[\mathrm{PtCl}(\mathrm{L})] @ M O F-5$. The crystal was scanned in z-direction in steps of $0.1 \mu \mathrm{m}$. The obtained images are shown from the top of the crystal (top left picture) to the middle of the crystal (bottom right picture). $\lambda_{\mathrm{exc}}=405 \mathrm{~nm}, \lambda_{\mathrm{em}}=550 \mathrm{~nm}$. 


\section{Section S10: Photophysical characterization of [PtCl(L)]@MOF and $[\operatorname{PtCN}(\mathrm{L})] @ M O F$}

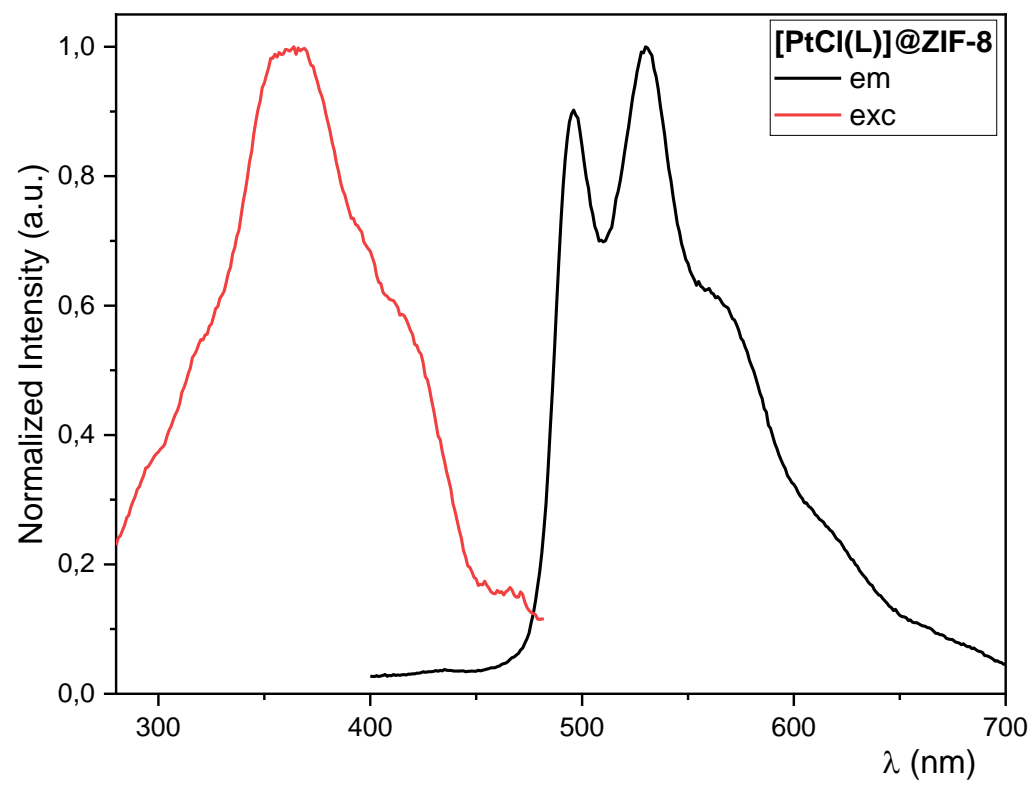

Figure S79. Excitation (red) and emission spectra (black) of $[\mathrm{PtCl}(\mathrm{L})] @ Z \mathbf{Z I F}-8\left(\lambda_{\mathrm{exc}}=350 \mathrm{~nm}, \lambda_{\mathrm{em}}=530 \mathrm{~nm}\right)$ at 298 K. Normalized at the highest intensity.

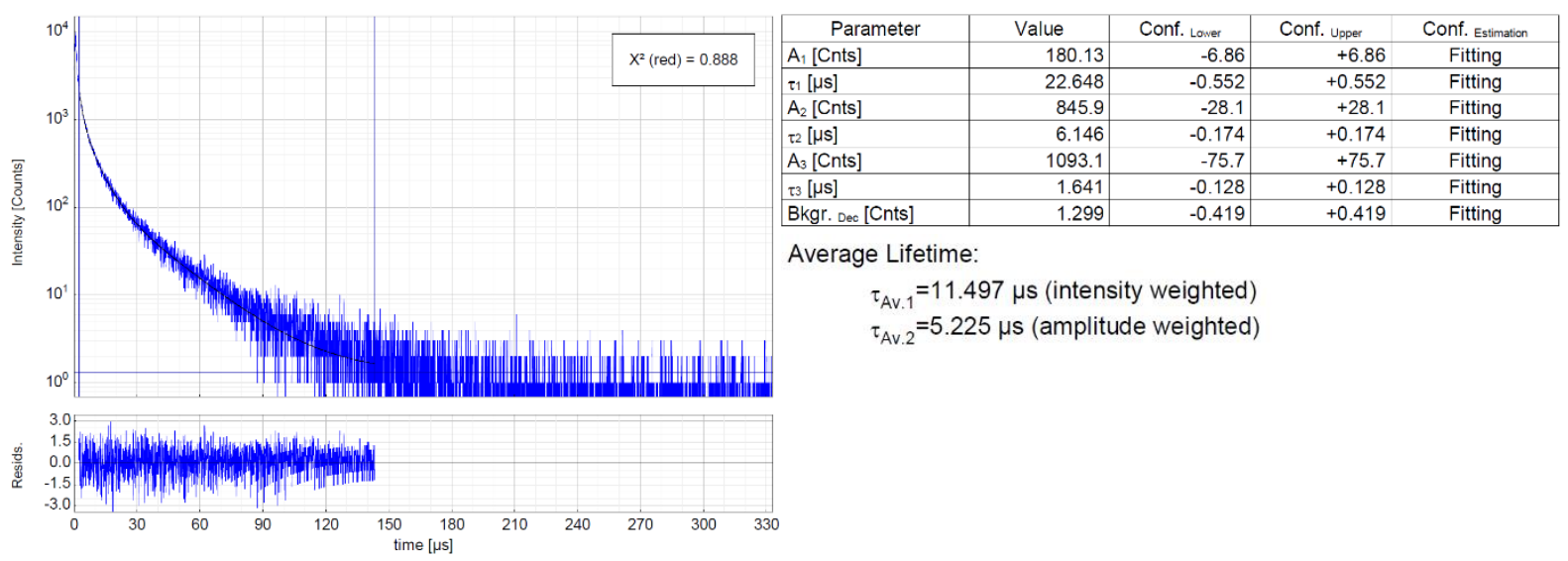

Figure S80. Left: Time-resolved luminescence decay of [PtCl(L)]@ZIF-8 at $298 \mathrm{~K}$ (air equilibrated), including the residuals $\left(\lambda_{\mathrm{exc}}=376.7 \mathrm{~nm}, \quad \lambda_{\mathrm{em}}=530 \mathrm{~nm}\right)$. Right: Fitting parameters including pre-exponential factors and confidence limits. 


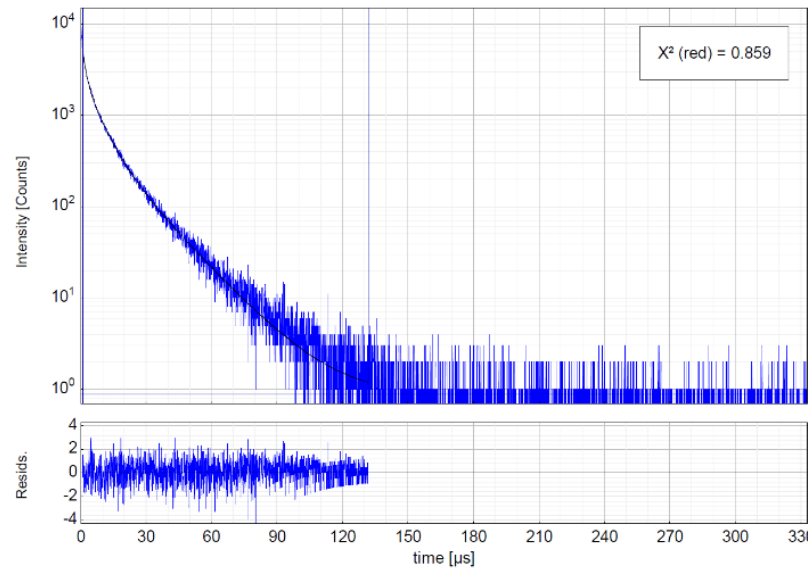

\begin{tabular}{|c|c|c|c|c|}
\hline Parameter & Value & Conf. Lower & Conf. Upper & Conf. Estimation \\
\hline$A_{1}[\mathrm{Cnts}]$ & 628.0 & -13.8 & +13.8 & Fitting \\
\hline$\tau_{1}[\mu \mathrm{s}]$ & 17.286 & -0.229 & +0.229 & Fitting \\
\hline $\mathrm{A}_{2}$ [Cnts] & 2009.8 & -41.4 & +41.4 & Fitting \\
\hline$\tau_{2}[\mu \mathrm{s}]$ & 6.262 & -0.111 & +0.111 & Fitting \\
\hline $\mathrm{A}_{3}[\mathrm{Cnts}]$ & 2407 & -116 & +116 & Fitting \\
\hline$\tau_{3}[\mu \mathrm{s}]$ & 1.5153 & -0.0848 & +0.0848 & Fitting \\
\hline Bkgr. $\mathrm{Dec}[\mathrm{Cnts}]$ & 0.871 & -0.421 & +0.421 & Fitting \\
\hline
\end{tabular}

Average Lifetime:

$\tau_{\text {Av. } 1}=10.041 \mu \mathrm{s}$ (intensity weighted)

$\tau_{\text {Av } 2}=5.370 \mu$ s (amplitude weighted)

Figure S81. Time-resolved luminescence decay of $[\mathrm{PtCl}(\mathrm{L})] @ Z \mathrm{ZF}-8$ at $298 \mathrm{~K}$ (argon atmosphere), including the residuals $\left(\lambda_{\mathrm{exc}}=376.7 \mathrm{~nm}, \lambda_{\mathrm{em}}=530 \mathrm{~nm}\right)$. Right: Fitting parameters including pre-exponential factors and confidence limits.

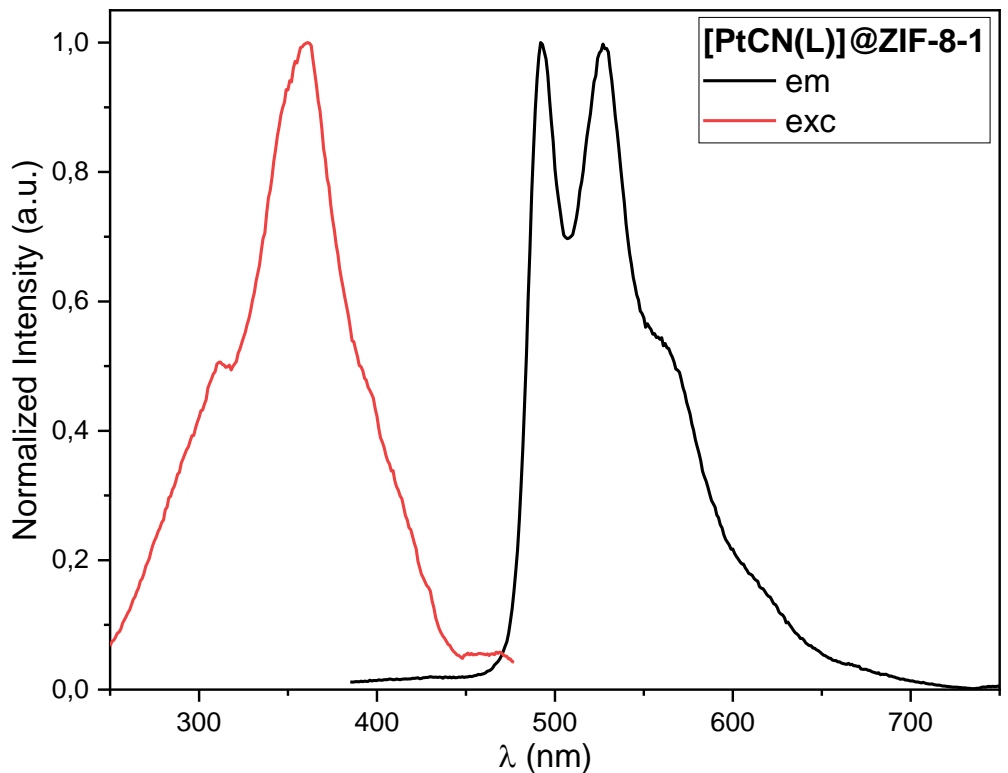

Figure S82. Excitation (red) and emission spectra (black) of [PtCN(L)]@ZIF-8-1 ( $\left.\lambda_{\text {exc }}=350 \mathrm{~nm}, \lambda_{\mathrm{em}}=530 \mathrm{~nm}\right)$ at 298 K. Normalized at the highest intensity.
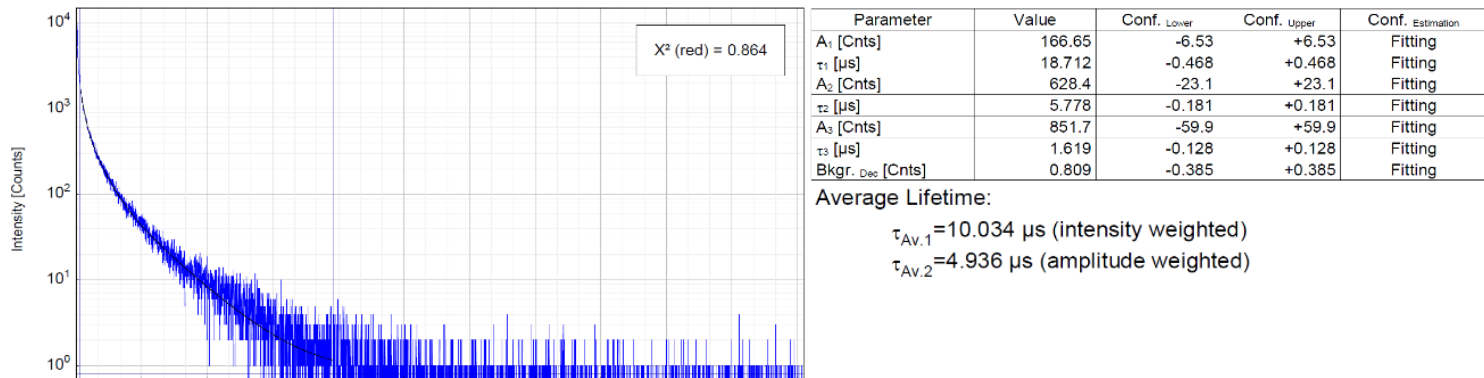

Average Lifetime:

$\tau_{\mathrm{Av} 1}=10.034 \mu \mathrm{s}$ (intensity weighted)

$\tau_{\mathrm{AV} .2}=4.936 \mu \mathrm{s}$ (amplitude weighted)

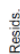

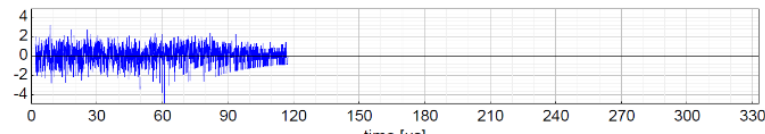

Figure S83. Left: Time-resolved luminescence decay of [PtCN(L)]@ZIF-8-1 at $298 \mathrm{~K}$ (air equilibrated), including the residuals $\left(\lambda_{\mathrm{exc}}=376.7 \mathrm{~nm}, \lambda_{\mathrm{em}}=530 \mathrm{~nm}\right)$. Right: Fitting parameters including pre-exponential factors and confidence limits. 


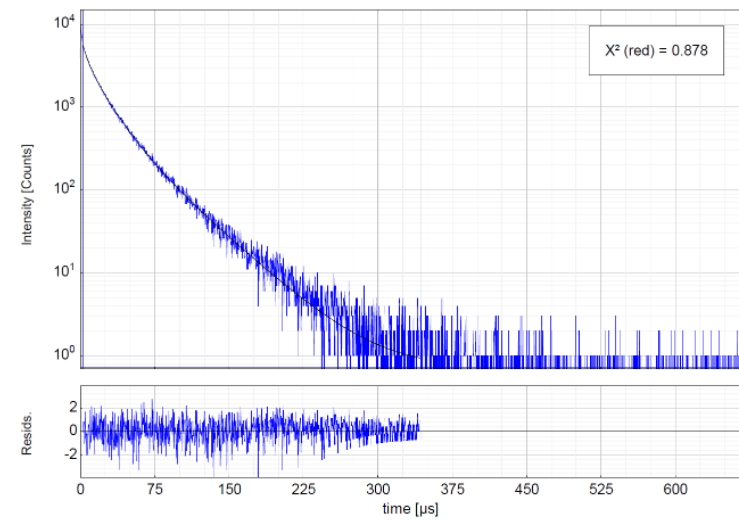

\begin{tabular}{|c|c|c|c|c|}
\hline Parameter & Value & Conf. Lower & Conf. Upper & Conf. Estimation \\
\hline$A_{1}[C n t s]$ & 963.1 & -18.9 & +18.9 & Fitting \\
\hline$\tau_{1}[\mu \mathrm{s}]$ & 40.684 & -0.458 & +0.458 & Fitting \\
\hline $\mathrm{A}_{2}$ [Cnts] & 2948.4 & -47.2 & +47.2 & Fitting \\
\hline$\tau_{2}[\mu \mathrm{s}]$ & 17.316 & -0.240 & +0.240 & Fitting \\
\hline$A_{3}[\mathrm{Cnts}]$ & 1594 & -118 & +118 & Fitting \\
\hline$\tau_{3}[\mu \mathrm{s}]$ & 4.600 & -0.411 & +0.411 & Fitting \\
\hline Bkgr. Dec [Cnts] & 0.712 & -0.408 & +0.408 & Fitting \\
\hline
\end{tabular}

Average Lifetime:

$\tau_{\mathrm{Av}, 1}=25.745 \mu \mathrm{s}$ (intensity weighted)

$\tau_{\text {Av. } 2}=17.723 \mu \mathrm{s}$ (amplitude weighted)

Figure S84. Left: Time-resolved luminescence decay of [PtCN(L)]@ZIF-8-1 at $298 \mathrm{~K}$ (argon atmosphere), including the residuals $\left(\lambda_{\mathrm{exc}}=376.7 \mathrm{~nm}, \lambda_{\mathrm{em}}=530 \mathrm{~nm}\right)$. Right: Fitting parameters including pre-exponential factors and confidence limits.

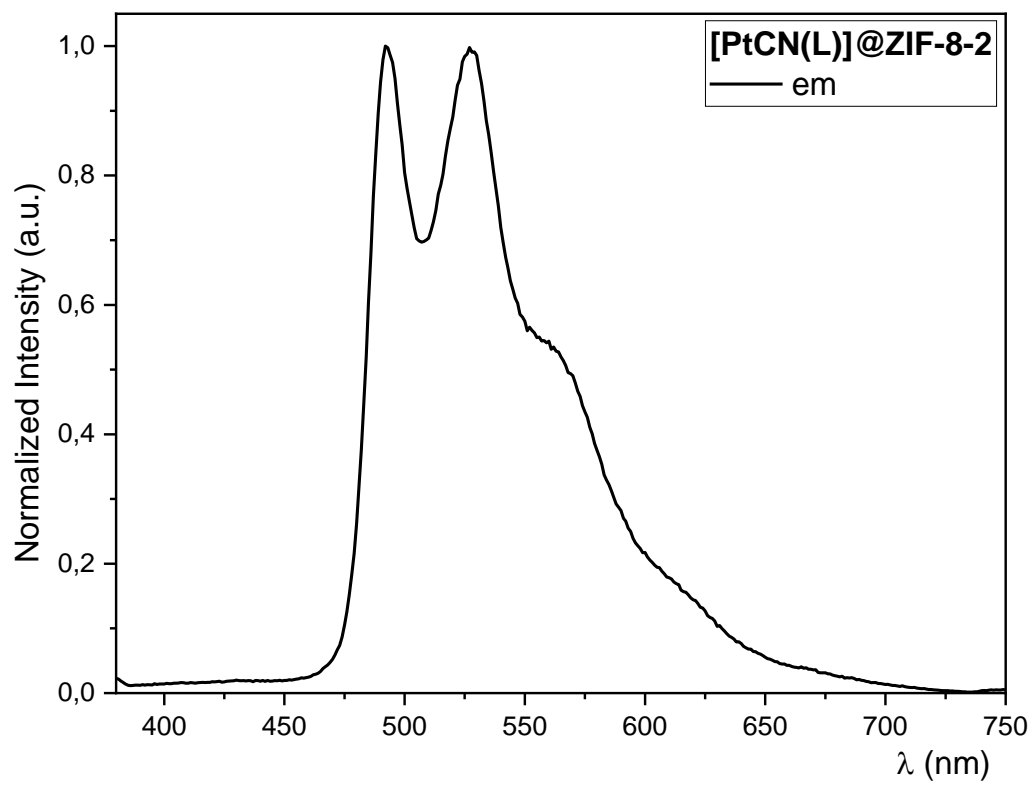

Figure S85. Emission spectrum (black) of $[\mathrm{PtCN}(\mathrm{L})] @ Z I F-8-2\left(\lambda_{\mathrm{exc}}=350 \mathrm{~nm}\right)$ at $298 \mathrm{~K}$. Normalized at the highest intensity.

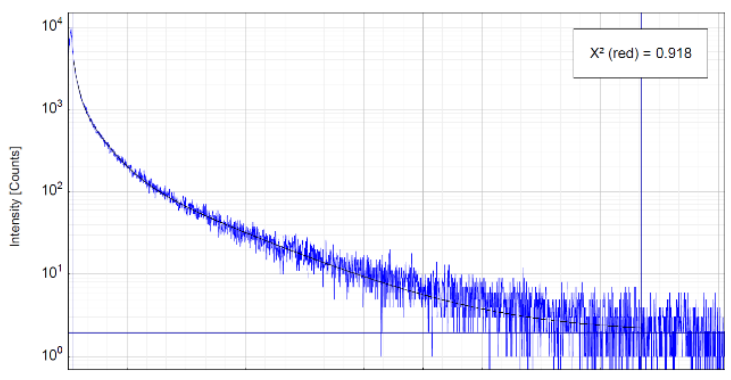

\begin{tabular}{|l|r|r|r|c|}
\hline \multicolumn{1}{|c|}{ Parameter } & \multicolumn{1}{c|}{ Value } & \multicolumn{1}{c|}{ Conf. Lower } & Conf. Upper & Conf. Estimation \\
\hline $\mathrm{A}_{1}[\mathrm{Cnts}]$ & 226.49 & -7.88 & +7.88 & Fitting \\
\hline$\tau 1[\mu \mathrm{s}]$ & 21.567 & -0.491 & +0.491 & Fitting \\
\hline $\mathrm{A}_{2}[\mathrm{Cnts}]$ & 1234.2 & -38.2 & +38.2 & Fitting \\
\hline$\tau_{2}[\mu \mathrm{s}]$ & 5.037 & -0.132 & +0.132 & Fitting \\
\hline $\mathrm{A}_{3}[\mathrm{Cnts}]$ & 2557 & -133 & +133 & Fitting \\
\hline$\tau 3$ [ $[\mu \mathrm{s}]$ & 1.0059 & -0.0583 & +0.0583 & Fitting \\
\hline Bkgr. Dec $[\mathrm{Cnts}]$ & 1.948 & -0.452 & +0.452 & Fitting \\
\hline
\end{tabular}

Average Lifetime:

$\tau_{\text {Av.1 }}=10.184 \mu$ s (intensity weighted)

$\tau_{\text {Av } 2}=3.403 \mu \mathrm{s}$ (amplitude weighted)

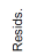

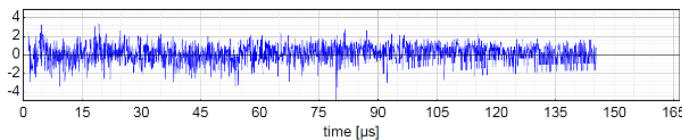

Figure S86. Left: Time-resolved luminescence decay of [PtCN(L)]@ZIF-8-2 at $298 \mathrm{~K}$ (air equilibrated), including the residuals $\left(\lambda_{\mathrm{exc}}=376.7 \mathrm{~nm}, \lambda_{\mathrm{em}}=530 \mathrm{~nm}\right)$. Right: Fitting parameters including pre-exponential factors and confidence limits. 


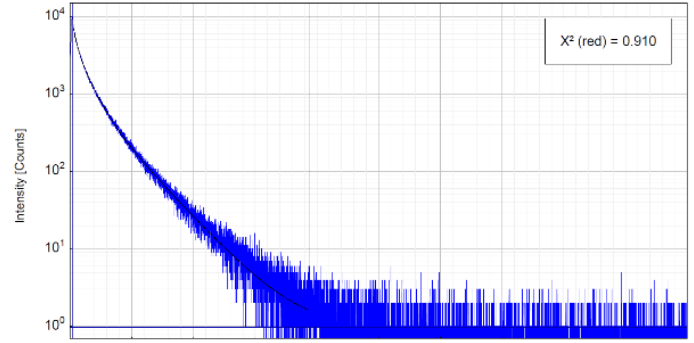

兽

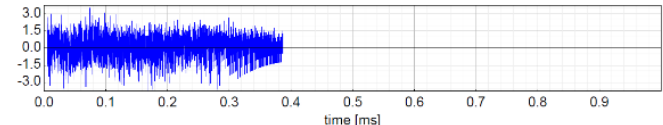

\begin{tabular}{|l|r|r|r|r|}
\hline \multicolumn{1}{|c|}{ Parameter } & Value & \multicolumn{1}{c|}{ Conf. Lower } & Conf. Upper & Conf. Estimation \\
\hline$A_{1}[\mathrm{Cnts}]$ & 1139.6 & -19.0 & +19.0 & Fitting \\
\hline$\tau_{1}[\mathrm{~ms}]$ & 0.051157 & -0.000496 & +0.000496 & Fitting \\
\hline $\mathrm{A}_{2}[\mathrm{Cnts}]$ & 3502.7 & -55.5 & +55.5 & Fitting \\
\hline$\tau 2$ [ms] & 0.018927 & -0.000257 & +0.000257 & Fitting \\
\hline $\mathrm{A}_{3}[\mathrm{Cnts}]$ & 3056 & -139 & +139 & Fitting \\
\hline$\tau 3$ [ms & 0.005311 & -0.000278 & +0.000278 & Fitting \\
\hline Bkgr. Dec [Cnts] & 0.970 & -0.513 & +0.513 & Fitting \\
\hline
\end{tabular}

Bkgr. Dec [Cnts]

0.970

$-0.513$

$+0.513$

Fitting

$\tau_{\mathrm{Av} .1}=0.030701 \mathrm{~ms}$ (intensity weighted)

$\tau_{\text {Av } 2}=0.018294 \mathrm{~ms}$ (amplitude weighted)

Figure S87. Left: Time-resolved luminescence decay of [PtCN(L)]@ZIF-8-2 at $298 \mathrm{~K}$ (argon atmosphere), including the residuals $\left(\lambda_{\text {exc }}=376.7 \mathrm{~nm}, \lambda_{\mathrm{em}}=530 \mathrm{~nm}\right)$. Right: Fitting parameters including pre-exponential factors and confidence limits.

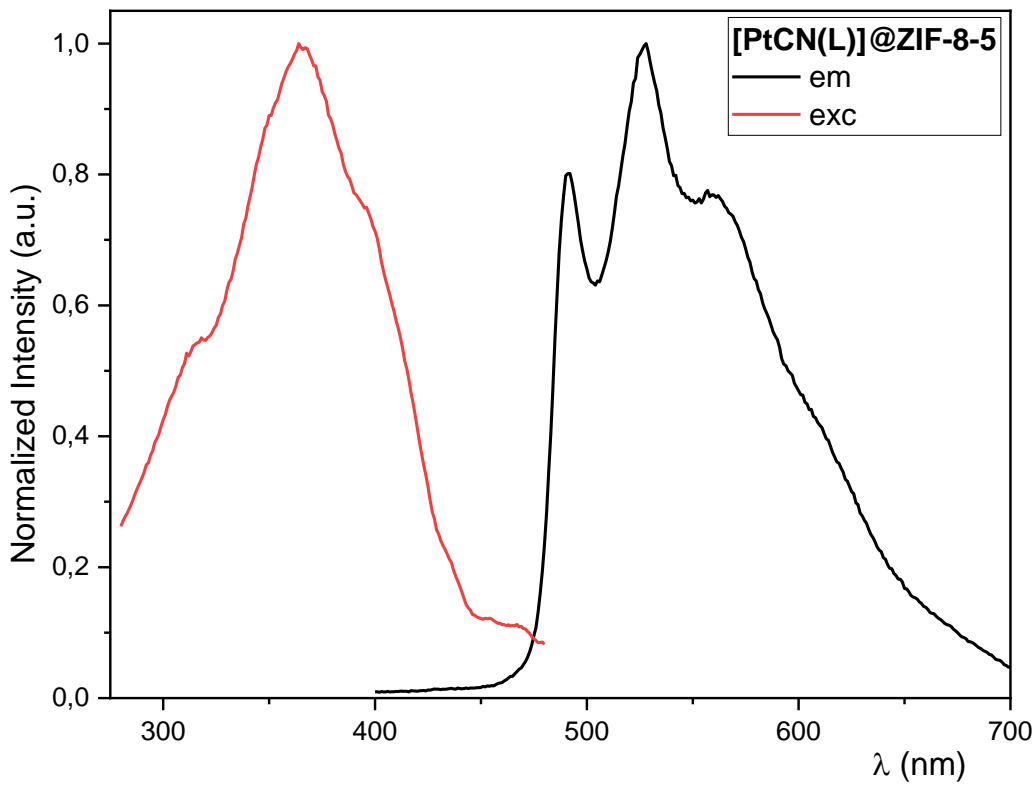

Figure S88. Excitation (red) and emission spectra (black) of $\left[\right.$ PtCN(L)]@ZIF-8-5 $\left(\lambda_{\text {exc }}=350 \mathrm{~nm}, \lambda_{\mathrm{em}}=530 \mathrm{~nm}\right)$ at 298 K. Normalized at the highest intensity.

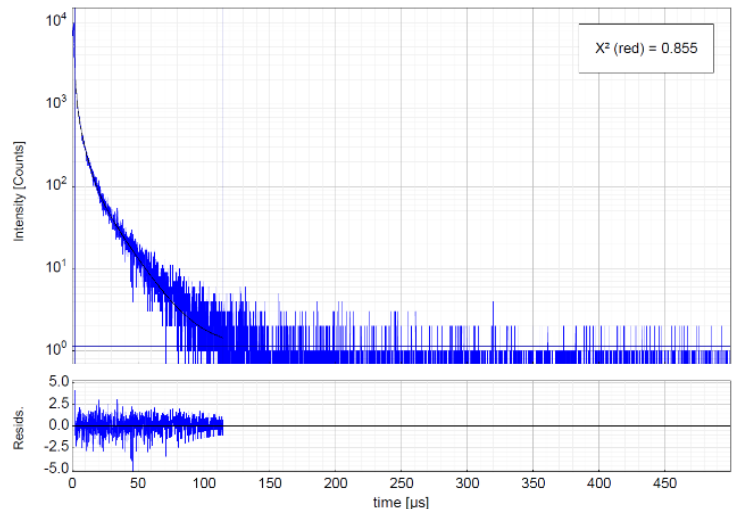

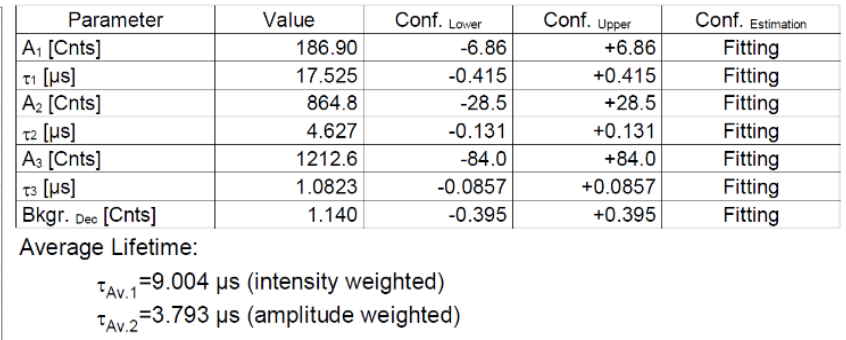

Figure S89. Left: Time-resolved luminescence decay of [PtCN(L)]@ZIF-8-5 at $298 \mathrm{~K}$ (air equilibrated), including the residuals $\left(\lambda_{\mathrm{exc}}=376.7 \mathrm{~nm}, \lambda_{\mathrm{em}}=530 \mathrm{~nm}\right)$. Right: Fitting parameters including pre-exponential factors and confidence limits. 


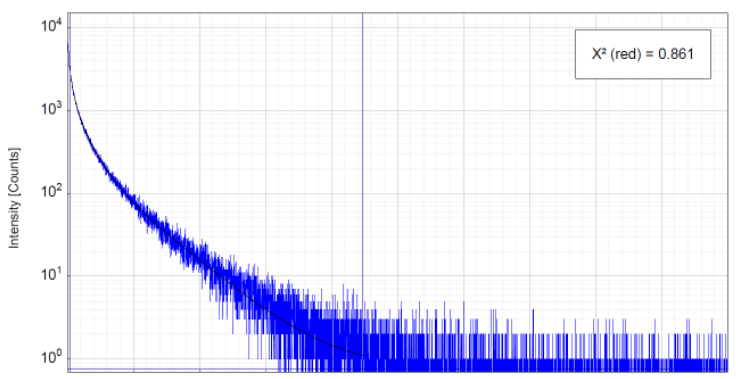

\begin{tabular}{|l|r|r|r|c|}
\hline \multicolumn{1}{|c|}{ Parameter } & \multicolumn{1}{c|}{ Value } & \multicolumn{1}{c|}{ Conf. Lower } & Conf. Upper & Conf. Estimation \\
\hline $\mathrm{A}_{1}[\mathrm{Cnts}]$ & 296.81 & -8.78 & +8.78 & Fitting \\
\hline$\tau 1[\mu \mathrm{s}]$ & 32.688 & -0.608 & +0.608 & Fitting \\
\hline $\mathrm{A}_{2}[\mathrm{Cnts}]$ & 1080.2 & -32.3 & +32.3 & Fitting \\
\hline$\tau_{2}[\mu \mathrm{s}]$ & 9.616 & -0.249 & +0.249 & Fitting \\
\hline $\mathrm{A}_{3}[\mathrm{Cnts}]$ & 1400.2 & -88.2 & +88.2 & Fitting \\
\hline$\tau_{3}[\mu \mathrm{s}]$ & 2.475 & -0.177 & +0.177 & Fitting \\
\hline Bkgr. Dec $[\mathrm{Cnts}]$ & 0.767 & -0.398 & +0.398 & Fitting \\
\hline
\end{tabular}

Average Lifetime:

$\tau_{\mathrm{Av} .1}=18.068 \mu \mathrm{s}$ (intensity weighted)

$\tau_{\mathrm{Av} .2}=8.481 \mu \mathrm{s}$ (amplitude weighted)

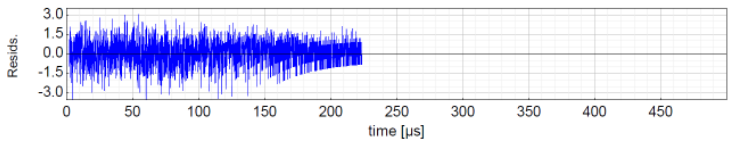

Figure S90. Left: Time-resolved luminescence decay of [PtCN(L)]@ZIF-8-5 at $298 \mathrm{~K}$ (argon atmosphere), including the residuals $\left(\lambda_{\mathrm{exc}}=376.7 \mathrm{~nm}, \lambda_{\mathrm{em}}=530 \mathrm{~nm}\right)$. Right: Fitting parameters including pre-exponential factors and confidence limits.

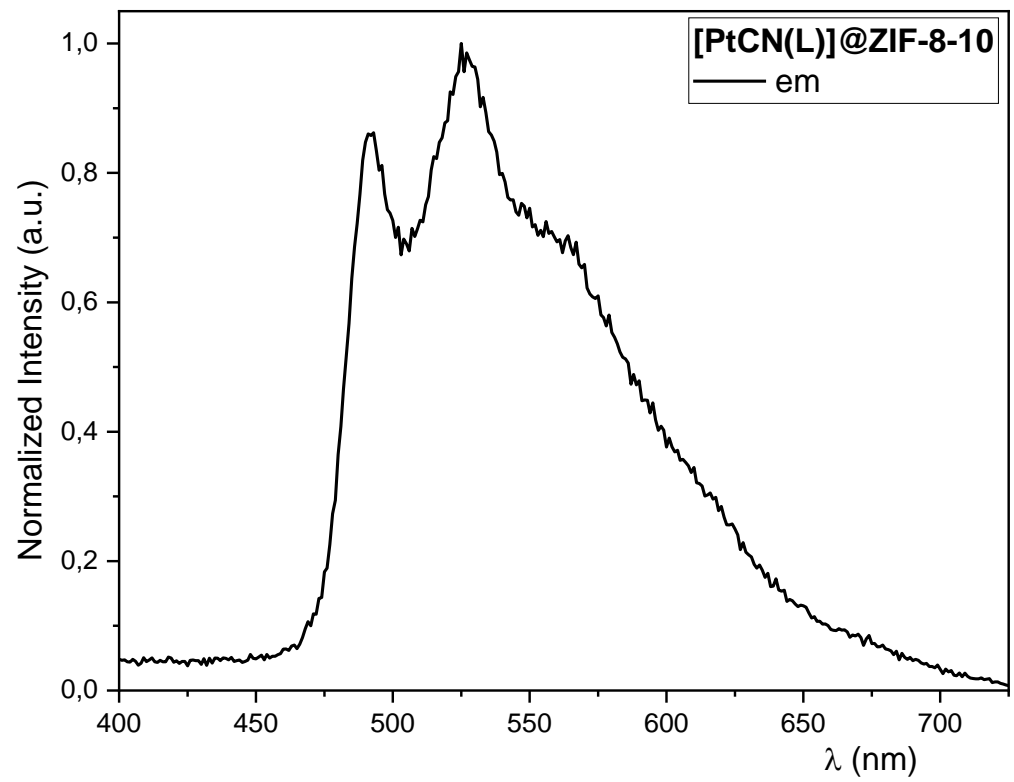

Figure S91. Emission spectrum (black) of [PtCN(L)]@ZIF-8-10 $\left(\lambda_{\mathrm{exc}}=350 \mathrm{~nm}\right)$ at room temperature. Normalized at the highest intensity.

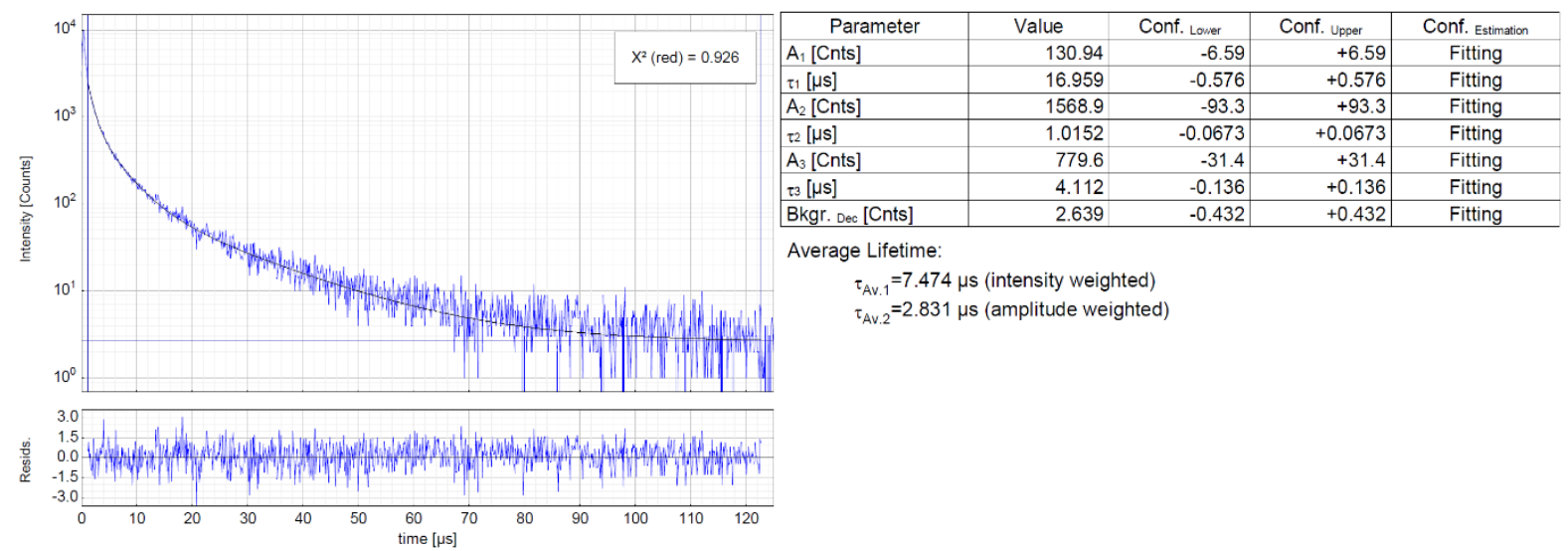

Figure S92. Left: Time-resolved luminescence decay of [PtCN(L)]@ZIF-8-10 at $298 \mathrm{~K}$ (air equilibrated), including the residuals $\left(\lambda_{\mathrm{exc}}=376.7 \mathrm{~nm}, \lambda_{\mathrm{em}}=530 \mathrm{~nm}\right)$. Right: Fitting parameters including pre-exponential factors and confidence limits. 


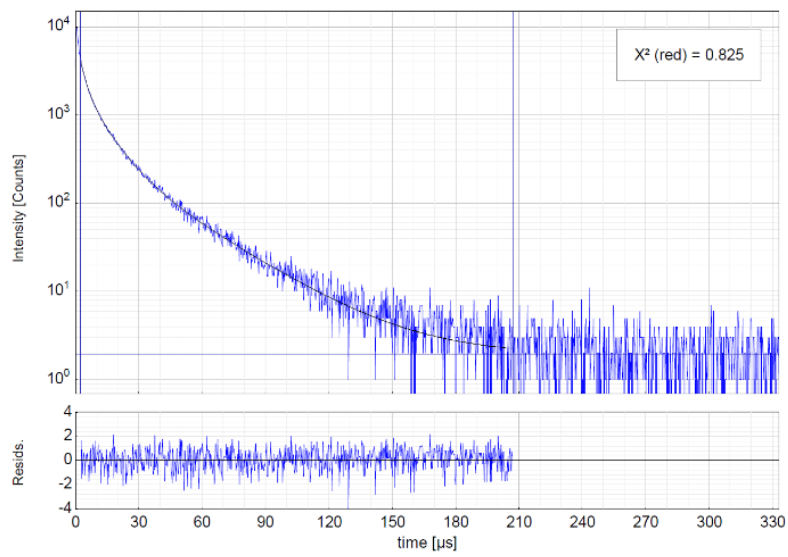

\begin{tabular}{|c|c|c|c|c|}
\hline Parameter & Value & Conf. Lower & Conf. Upper & Conf. Estimation \\
\hline$A_{1}[\mathrm{Cnts}]$ & 396.6 & -10.6 & +10.6 & Fitting \\
\hline$\tau_{11}[\mu \mathrm{s}]$ & 28.807 & -0.472 & +0.472 & Fitting \\
\hline $\mathrm{A}_{2}$ [Cnts] & 1658.8 & -37.0 & +37.0 & Fitting \\
\hline$\tau 2[\mu \mathrm{s}]$ & 9.251 & -0.176 & +0.176 & Fitting \\
\hline$A_{3}[\mathrm{Cnts}]$ & 1956.0 & -95.5 & +95.5 & Fitting \\
\hline$\tau_{3}[\mu \mathrm{s}]$ & 2.526 & -0.143 & +0.143 & Fitting \\
\hline Bkgr. Dec [Cnts] & 1.930 & -0.457 & +0.457 & Fitting \\
\hline
\end{tabular}

Average Lifetime

$\tau_{\text {Av } 1}=15.248 \mu \mathrm{s}$ (intensity weighted)

$\tau_{\mathrm{Av} .2}=7.905 \mu \mathrm{s}$ (amplitude weighted)

Figure S93. Left: Time-resolved luminescence decay of [PtCN(L)]@ZIF-8-10 at $298 \mathrm{~K}$ (argon atmosphere), including the residuals $\left(\lambda_{\mathrm{exc}}=376.7 \mathrm{~nm}, \lambda_{\mathrm{em}}=530 \mathrm{~nm}\right)$. Right: Fitting parameters including pre-exponential factors and confidence limits.

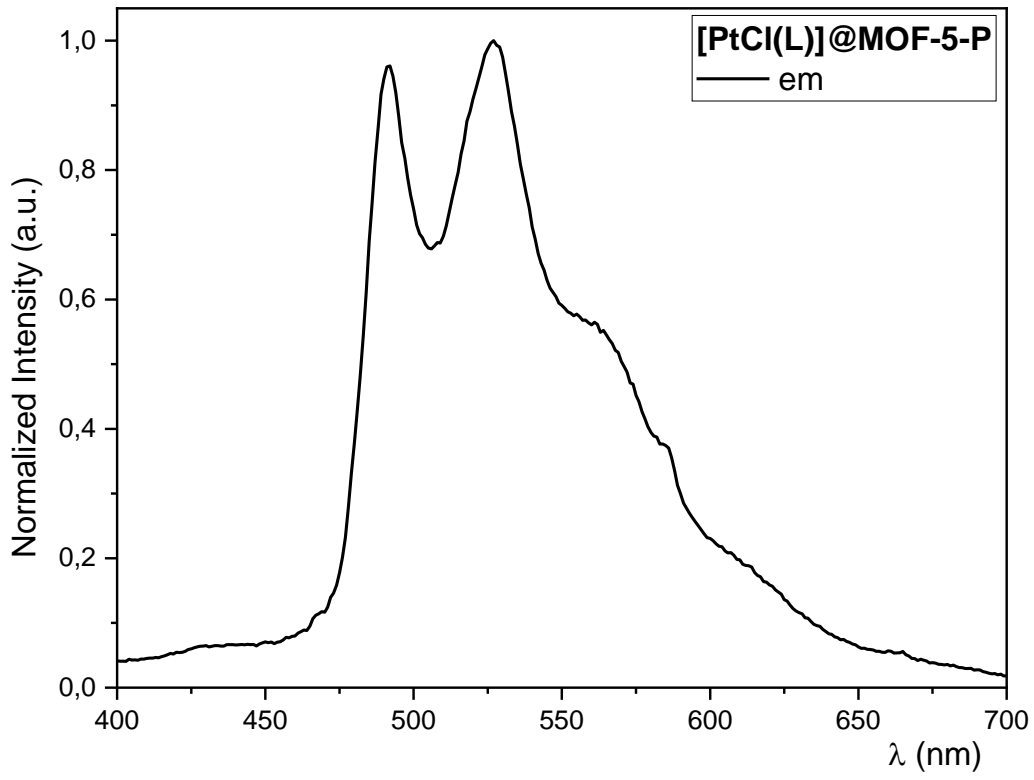

Figure S94. Emission spectrum (black) of $[\mathrm{PtCl}(\mathrm{L})] @ M O F-5$ (powder) at $298 \mathrm{~K}\left(\lambda_{\mathrm{exc}}=350 \mathrm{~nm}\right)$. Normalized at the highest intensity.

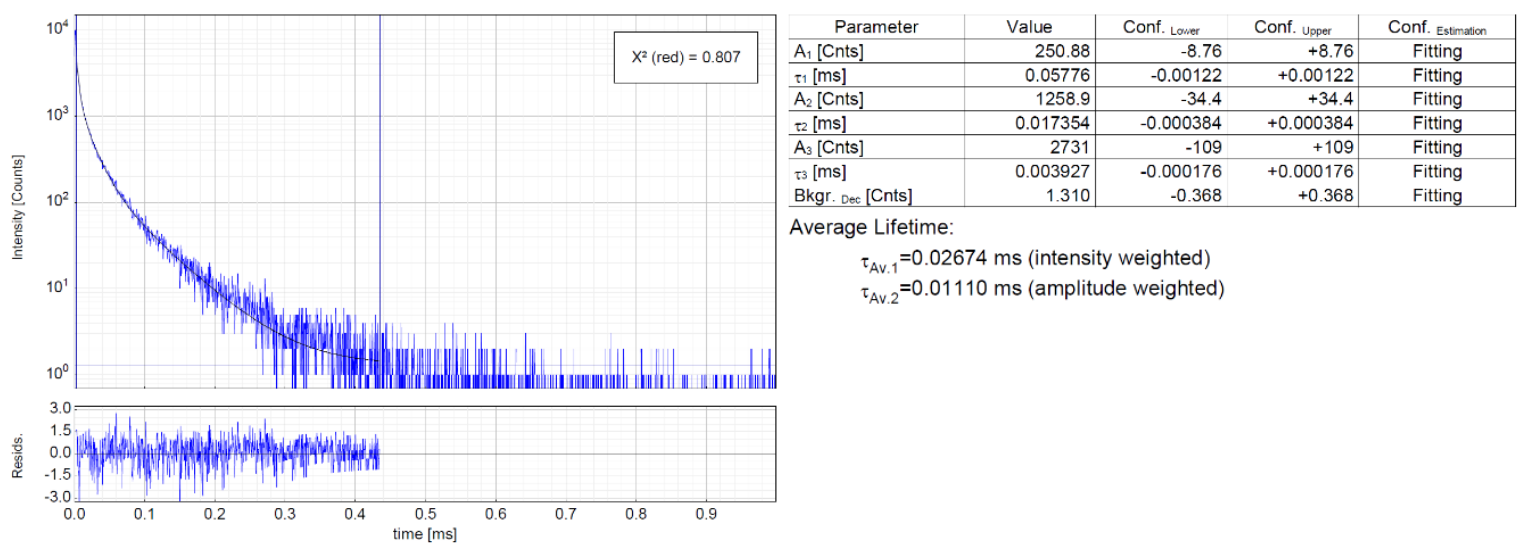

Figure S95. Left: Time-resolved luminescence decay of [PtCl(L)]@MOF-5 (powder) at $298 \mathrm{~K}$ (argon atmosphere), including the residuals $\left(\lambda_{\mathrm{exc}}=376.7 \mathrm{~nm}, \lambda_{\mathrm{em}}=530 \mathrm{~nm}\right)$. Right: Fitting parameters including pre-exponential factors and confidence limits. 


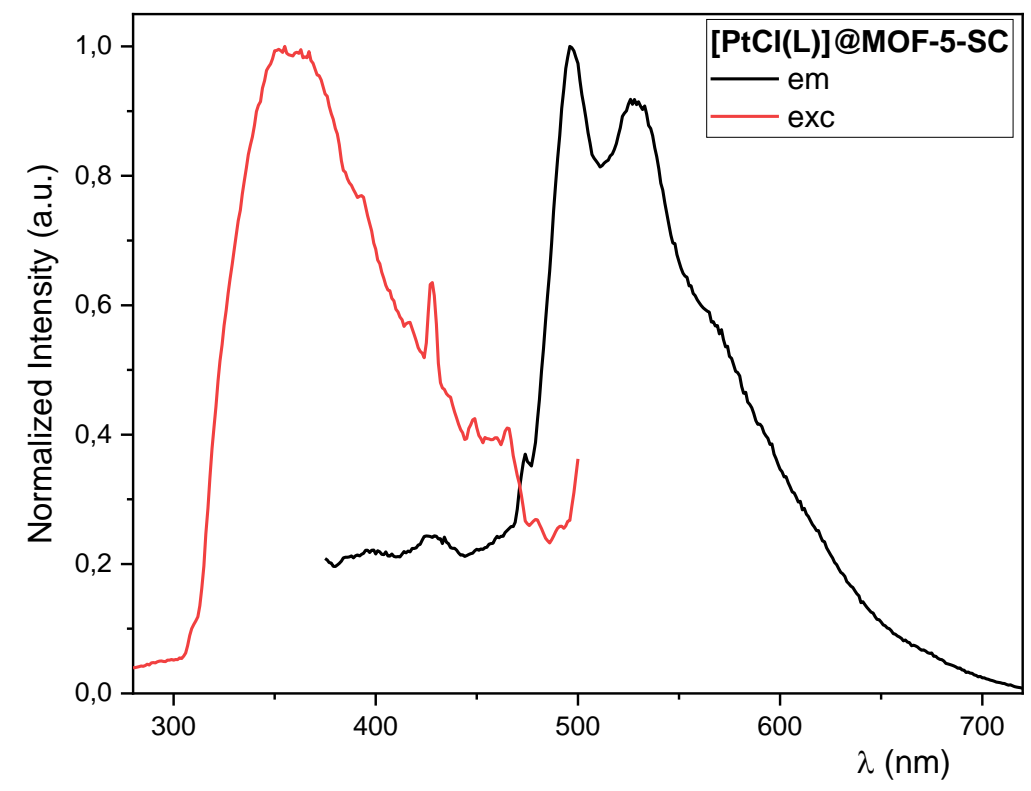

Figure S96. Excitation (red) and emission spectra (black) of [PtCl(L)]@MOF-5 (single crystals) in $n$-hexane $\left(\lambda_{\text {exc }}=350 \mathrm{~nm}\right)$ at room temperature. Normalized at the highest intensity.

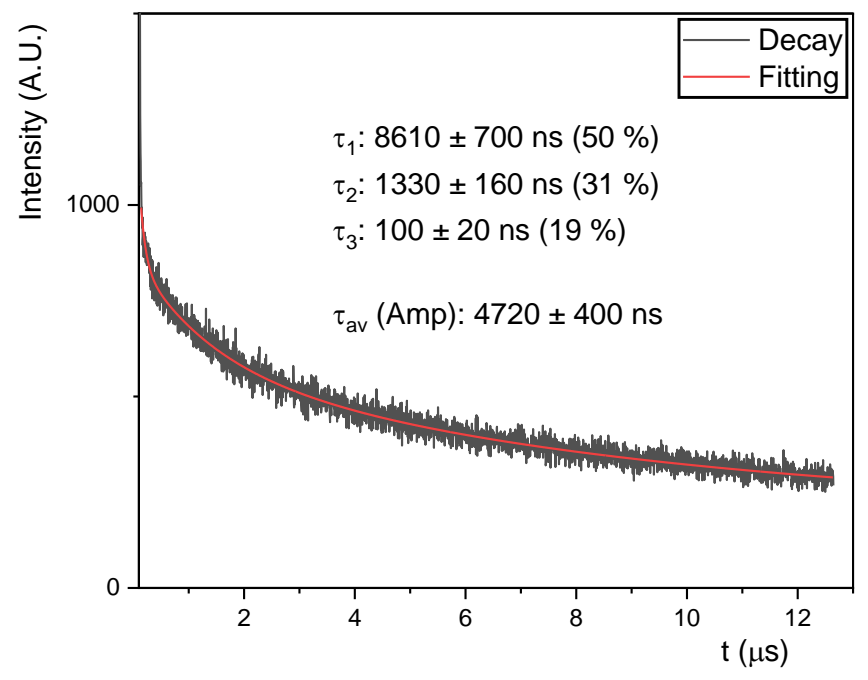

Figure S97. Time-resolved luminescence decay of $[\mathrm{PtCl}(\mathrm{L})] @ M O F-5$ (single crystals) at $298 \mathrm{~K}$ (argon atmosphere), including the residuals $\left(\lambda_{\mathrm{exc}}=376.7 \mathrm{~nm}, \lambda_{\mathrm{em}}=530 \mathrm{~nm}\right)$. Inset: Fitting parameters including preexponential factors and confidence limits. 


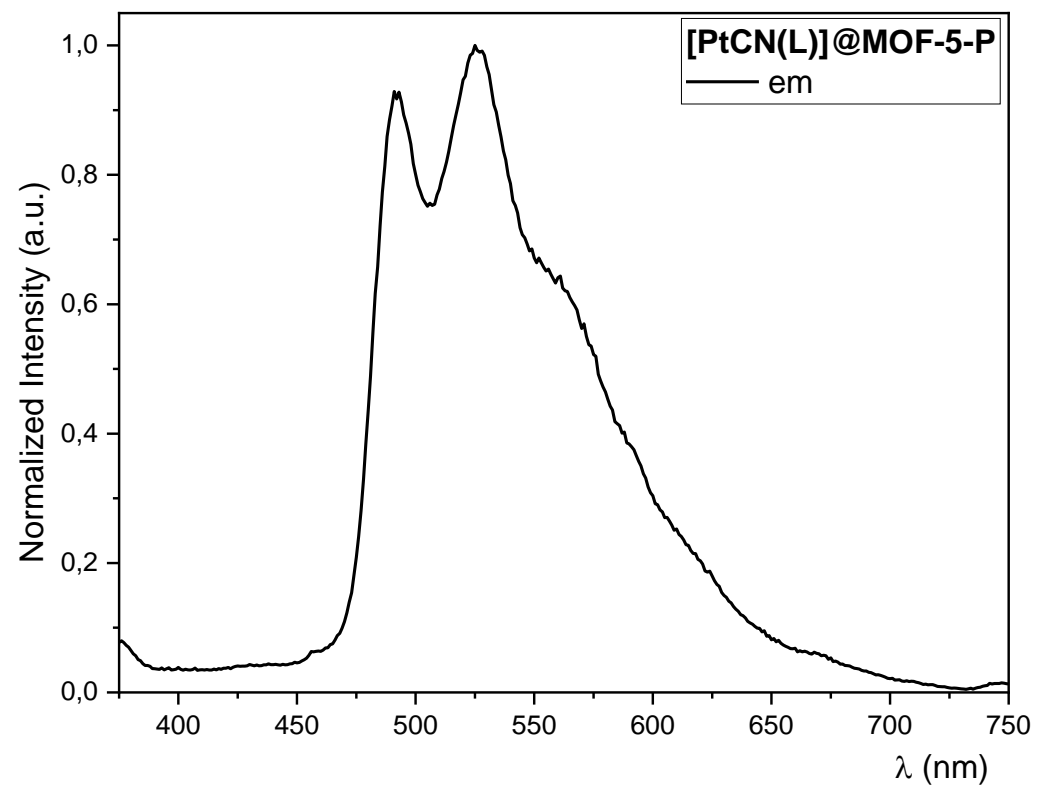

Figure S98. Emission spectrum (black) of $[\mathrm{PtCN}(\mathrm{L})] @ M O F-5$ (powder) at room temperature $\left(\lambda_{\mathrm{exc}}=350 \mathrm{~nm}\right)$. Normalized at the highest intensity.

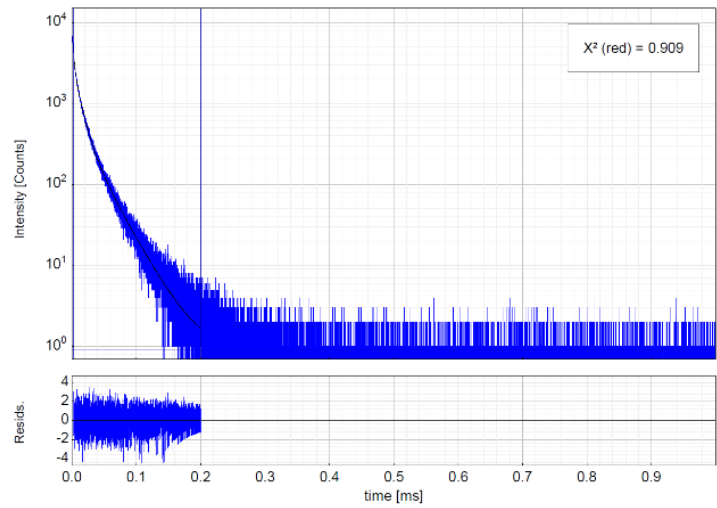

\begin{tabular}{|l|r|r|r|r|}
\hline \multicolumn{1}{|c|}{ Parameter } & Value & Conf. Lower & Conf. Upper & Conf. Estimation \\
\hline $\mathrm{A}_{1}[\mathrm{Cnts}]$ & 1379.1 & -89.2 & +89.2 & Fitting \\
\hline$\tau 1[\mathrm{~ms}]$ & 0.003191 & -0.000236 & +0.000236 & Fitting \\
\hline $\mathrm{A}_{2}[\mathrm{Cnts}]$ & 515.5 & -12.0 & +12.0 & Fitting \\
\hline$\tau_{2}[\mathrm{~ms}]$ & 0.030349 & -0.000415 & +0.000415 & Fitting \\
\hline $\mathrm{A}_{3}[\mathrm{Cnts}]$ & 1807.8 & -37.8 & +37.8 & Fitting \\
\hline$\tau_{3}[\mathrm{~ms}]$ & 0.010408 & -0.000191 & +0.000191 & Fitting \\
\hline Bkgr. Dec [Cnts] & 0.900 & -0.501 & +0.501 & Fitting \\
\hline
\end{tabular}

$$
\begin{aligned}
\tau_{\mathrm{Av} .1} & =0.017619 \mathrm{~ms} \text { (intensity weighted) } \\
\tau_{\mathrm{Av} .2} & =0.010496 \mathrm{~ms} \text { (amplitude weighted) }
\end{aligned}
$$

Figure S99. Left: Time-resolved luminescence decay of [PtCN(L)]@MOF-5 (powder) at 298 K (argon atmosphere), including the residuals $\left(\lambda_{\mathrm{exc}}=376.7 \mathrm{~nm}, \lambda_{\mathrm{em}}=530 \mathrm{~nm}\right)$. Right: Fitting parameters including pre-exponential factors and confidence limits. 


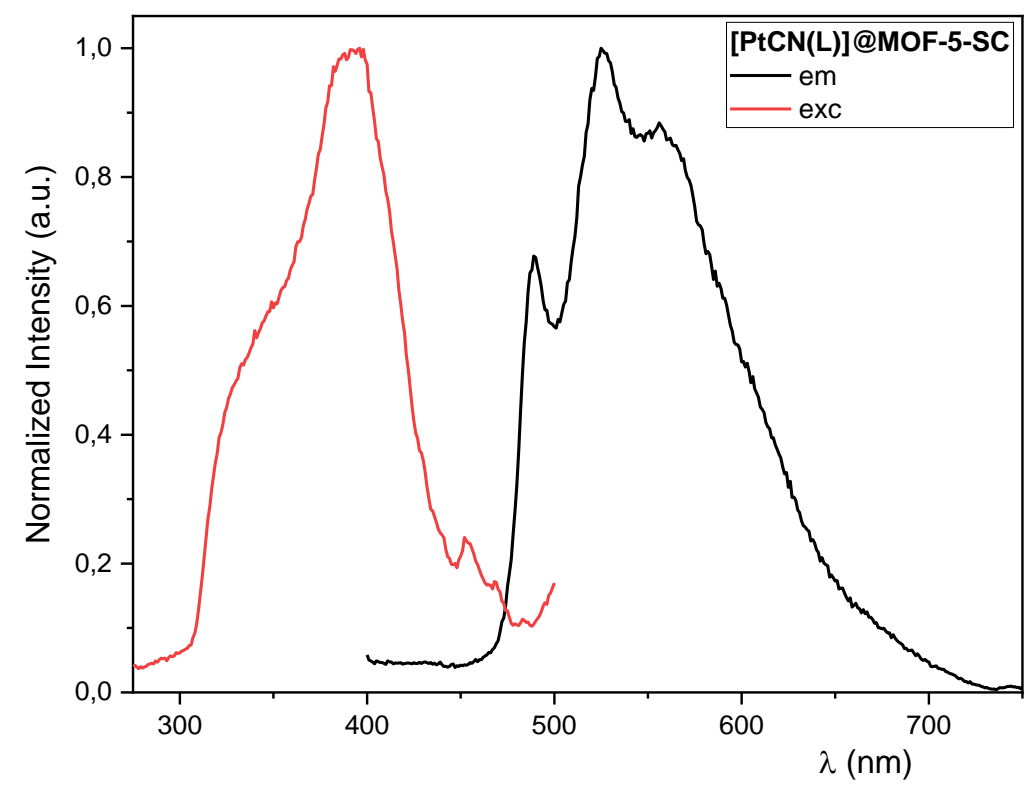

Figure S100. Excitation (red) and emission spectra (black) of [PtCN(L)]@MOF-5 (single crystals) in $n$-hexane $\left(\lambda_{\mathrm{exc}}=350 \mathrm{~nm}\right)$ at room temperature. Normalized at the highest intensity.

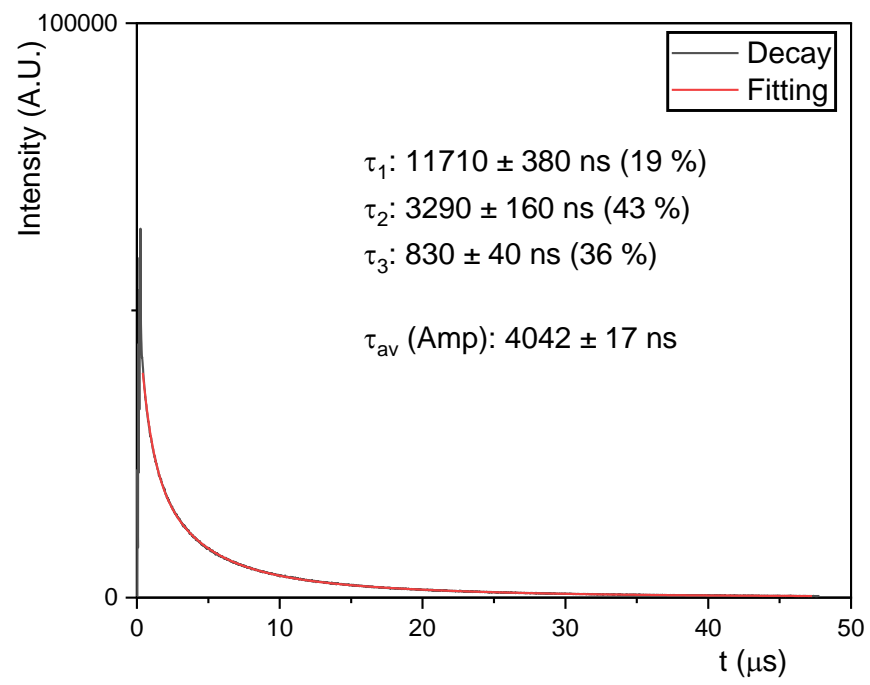

Figure S101. Time-resolved luminescence decay of [PtCN(L)]@MOF-5 (single crystals) at $298 \mathrm{~K}$ (argon atmosphere), including the residuals $\left(\lambda_{\mathrm{exc}}=376.7 \mathrm{~nm}, \lambda_{\mathrm{em}}=530 \mathrm{~nm}\right)$. Inset: Fitting parameters including preexponential factors and confidence limits. 


\section{References}

${ }^{1}$ Giannozzi, P.; Baroni, S.; Bonini, N.; Calandra, M.; Car, R.;Cavazzoni, C.; Ceresoli, D.; Chiarotti, G. L.; Cococcioni, M.; Dabo, I.; Dal Corso, A.; de Gironcoli, S.; Fabris, S.; Fratesi, G.; Gebauer, R.; Gerstmann, U.; Gougoussis, C.; Kokalj, A.; Lazzeri, M.; Martin-Samos, L.; Marzari, N.; Mauri, F.; Mazzarello, R.; Paolini, S.; Pasquarello, A.; Paulatto, L.; Sbraccia, C.; Scandolo, S.; Sclauzero, G.; Seitsonen, A. P.; Smogunov, A.; Umari, P.; Wentzcovitch, R. M. QUANTUM ESPRESSO: A Modular and OpenSource Software Project for Quantum Simulations of Materials. J. Phys.: Condens. Matter 2009, 21, 395502.

2 Grimme, S. Semiempirical GGA-Type Density Functional Constructed with a LongRange Dispersion Correction. J. Comput. Chem. 2006, 27, 1787.

${ }^{3}$ APEX3 (2016), SAINT (2015) and SADABS (2015), Bruker AXS Inc., Madison, Wisconsin, USA.

${ }^{4}$ Sheldrick, G. M., SHELXT - Integrated space-group and crystal-structure determination, Acta Cryst. 2015, A71, 3.

5 Sheldrick, G.M., Crystal structure refinement with SHELXL, Acta Cryst. 2015, C71 (1), 3.

${ }^{6}$ Hooft, R. W. W., Nonius B. V., COLLECT, Program for Collecting Data on CCD Area Detectors 1998, Delft, The Netherlands.

7 Z. Otwinowski, W. Minor, Methods Enzymol. 1997, 276, 307.

8 Z. Otwinowski, D. Borek, W. Majewski, W. Minor, Acta Crystallogr. Sect. A 2003, 59, 228.

${ }^{9}$ Hooft, R. W. W., Nonius B. V., COLLECT, Program for Collecting Data on CCD Area Detectors, 1998, Delft, The Netherlands.

${ }^{10}$ Cravillon, J.; Münzer, S.; Lohmeier, S.-J.; Feldhoff, A.; Huber, K.; Wiebcke, M. Rapid Room-Temperature Synthesis and Characterization of Nanocrystals of a Prototypical Zeolitic Imidazolate Framework. Chem. Mater. 2009, 21, 1410.

11 Tranchemontagne, D. J.; Hunt, J. R.; Yaghi, O. M. Room temperature synthesis of metal-organic frameworks: MOF-5, MOF-74, MOF-177, MOF-199, and IRMOF-0. Tetrahedron 2008, 64, 8553.

12 Han, S.; Wei, Y.; Valente, C.; Lagzi, I.; Gassensmith, J. J.; Coskun, A.; Stoddart, J. F.; Grzybowski, B. A. Chromatography in a single metal-organic framework (MOF) crystal. J. Am. Chem. Soc. 2010, 132, 16358.

${ }^{13}$ Park, K. S.; Ni, Z.; Cote, A. P.; Choi, J. Y.; Huang, R.; Uribe-Romo, F. J.; Chae, H. K.; O'Keeffe, M.; Yaghi, O. M. Exceptional chemical and thermal stability of zeolitic imidazolate frameworks. Proc. Nat. Acad. Sci. 2006, 103, 10186. 
${ }^{14}$ Lock, N.; Wu, Y.; Christensen, M.; Cameron, L. J.; Peterson, V. K.; Bridgeman, A. J.; Kepert, C. J.; Iversen, B. B. Elucidating Negative Thermal Expansion in MOF-5. J. Phys. Chem. C 2010, 114, 16181.

15 Tsoufis, T.; Tampaxis, C.; Spanopoulos, I.; Steriotis, T.; Katsaros, F.; Charalambopoulou, G.; Trikalitis, P. N. High-quality graphene sheets decorated with ZIF-8 nanocrystals. Microporous Mesoporous Mater. 2018, 262, 68.

${ }^{16}$ Fairen-Jimenez, D.; Moggach, S. A.; Wharmby, M. T.; Wright, P. A.; Parsons, S.; Düren, T. Opening the gate: Framework flexibility in ZIF-8 explored by experiments and simulations. J. Am. Chem. Soc. 2011, 133, 8900.

17 Pan, Y.; Liu, Y.; Zeng, G.; Zhao, L.; Lai, Z. Rapid synthesis of zeolitic imidazolate framework-8 (ZIF-8) nanocrystals in an aqueous system. Chem. Commun. 2011, 47, 2071.

18 Huang, X.-C.; Lin, Y.-Y.; Zhang, J.-P.; Chen, X.-M. Ligand-directed strategy for zeolite-type metal-organic frameworks: Zinc(II) imidazolates with unusual zeolitic topologies. Angew. Chem. Int. Ed. 2006, 45, 1557.

${ }^{19}$ Novaković, S. B.; Bogdanović, G. A.; Heering, C.; Makhloufi, G.; Francuski, D.; Janiak, C. Charge-density distribution and electrostatic flexibility of ZIF-8 based on high-resolution X-ray diffraction data and periodic calculations. Inorg. Chem. 2015, 54, 2660.

20 Tanaka, S.; Fujita, K.; Miyake, Y.; Miyamoto, M.; Hasegawa, Y.; Makino, T.; van der Perre, S.; Cousin Saint Remi, J.; van Assche, T.; Baron, G. V. et al. Adsorption and Diffusion Phenomena in Crystal Size Engineered ZIF-8 MOF. J. Phys. Chem. C 2015, $119,28430$. 